UNIVERSIDADE DE SÃO PAULO

FFCLRP - DEPARTAMENTO DE PSICOLOGIA

PROGRAMA DE PÓS-GRADUAÇÃO EM PSICOLOGIA

\title{
Corpus Alienum:
}

efeitos do discurso das novas dietas, corpo-projeto e mídia



Rodrigo Daniel Sanches

Ribeirão Preto - SP

2018 
Corpus Alienum:

efeitos do discurso das novas dietas, corpo-projeto e mídia

\section{Versão Corrigida}

Tese apresentada à Faculdade de Filosofia, Ciências e Letras de Ribeirão Preto da USP, como parte das exigências para a obtenção do título de Doutor em Ciências. Área: Psicologia: Processos Culturais e Subjetivação.

Orientadora: Profa. Dra. Lucília Maria Abrahão e Sousa

Ribeirão Preto - SP

2018 
Autorizo a reprodução e divulgação total ou parcial deste trabalho, por qualquer meio convencional ou eletrônico, para fins de estudo e pesquisa, desde que citada a fonte.

Sanches, Rodrigo Daniel.

Corpus Alienum: efeitos do discurso das novas dietas, corpo-projeto e mídia. Ribeirão Preto, 2018.

p. 204: il.; $30 \mathrm{~cm}$

Tese de Doutorado, apresentada à Faculdade de Filosofia, Ciências e Letras de Ribeirão Preto/USP. Área de concentração: Psicologia: Processos Culturais e Subjetivação.

Orientadora: Sousa, Lucília Maria Abrahão e.

1. Discurso. 2. Dietas. 3. Novo e novidade. 4. Corpo-projeto. 5. Mídia.

Capa

Night Portrait Face Down (1999-2000)

Lucian Freud 


\section{FOLHA DE APROVAÇÃO}

Rodrigo Daniel Sanches

Corpus Alienum: efeitos do discurso das novas dietas, corpo-projeto e mídia

Tese apresentada à Faculdade de Filosofia, Ciências e Letras de Ribeirão Preto da Universidade de São Paulo, como parte das exigências para a obtenção do título de Doutor em Ciências. Área de Concentração: Psicologia.

Aprovado em:

\section{Banca Examinadora}

Prof. Dr.

Instituição:

Assinatura:

Prof. Dr.

Instituição:

Assinatura:

Prof. Dr.

Instituição:

Assinatura:

Prof. Dr.

Instituição:

Assinatura:

Prof. Dr.

Instituição:

Assinatura: 


\section{Agradecimento especial}

À minha orientadora, Prof. ${ }^{a}$ Lucília Maria Abrahão e Sousa, por me conduzir neste percurso. Pela generosidade com que me ensinou outras possibilidades e caminhos. Pelas palavras de incentivo e, principalmente, pela capacidade de notar quando mais precisamos delas. Pela parceria de vida e aprendizado. Pela poesia que faz tudo parecer mais fácil, quando sabemos que não o é. Pela alegria que desmonta a insegurança, e por ter me encorajado a acolher um futuro que ainda não existia. Mas que, de alguma forma, já estava lá! Por insistir na juventude. Por tudo isso e também por aquilo que não consigo expressar através da escrita, muito obrigado. 


\section{Agradecimentos \\ (sentidos de gratidão)}

Ao meu amor, Maristela Schaufelberger Spanghero, por me incentivar a viver aquilo que não seria possível vivenciar sozinho. Pelo suporte para que esse projeto de vida pudesse acontecer. E por tudo, absolutamente tudo. Que você sabe o que é, mas eu não poderia - e nem teria capacidade - para descrever em poucas linhas. É a história de uma vida. E uma vida não cabe em frases ou sentenças. Nunca se esqueça: Only lovers left alive!

Aos meus pais, Daniel e Geni, à minha irmã, Regina, ao meu sobrinho, Danilo, ao meu cunhado, Damião. Por tudo o que eles representam na minha vida. A gratidão que sinto por eles também não pode ser descrita. Não faz parte do intelecto. Não pode ser medida, mensurada. Apenas existe.

Ao Prof. João Batista Ernesto de Moraes, por acompanhar minha trajetória desde a graduação até o Mestrado e, agora, participando de modo expressivo na construção deste Doutorado. Pela leitura e reflexão feitas com humor e sagacidade. Prof. João Batista, você gosta de jazz?

Ao Prof. Norval Baitello Jr., por continuar me incentivando a estranhar o mundo não como ele é, mas sim como parece ser. E por me ensinar a encarar com assombro os sussurros das imagens que nos rodeiam. Por me receber (e me acolher) em São Paulo novamente. Por fazer do reencontro não um recomeço ou um começo, mas um prosseguir.

À Prof. ${ }^{a}$ Soraya Maria Romano Pacífico, pela leitura e significativa contribuição a este trabalho. Pela sua participação nos grupos de pesquisa, momentos inestimáveis para aprofundar as teorias e as amizades.

Ao médico psiquiatra e Prof. Celso Garcia Junior, pela leitura atenta e por me incentivar a divulgar o trabalho junto aos grupos de pesquisa de transtornos alimentares.

À nutricionista e Prof. ${ }^{a}$ Rosa Wanda Diez-Garcia, coordenadora do grupo PrátiCA, Laboratório de Práticas e Comportamento Alimentares da Faculdade de Medicina de Ribeirão Preto (FMRP/USP), e ao médico e Prof. José Ernesto dos Santos, chefe do Grupo de Assistência em Transtornos Alimentares do Hospital das Clínicas da Faculdade de Medicina de Ribeirão Preto (GRATA-HCFMRP/USP), e suas respectivas equipes, pelos convites para que eu proferisse palestras em eventos de nutrição e saúde, iniciando um profícuo e instigante diálogo com profissionais da área.

Ao casal Martinho Alves da Costa Júnior e Letícia Badan Palhares Knauer de Campos, pela amizade sempre afetuosa. E pelas ocasiões singulares que tornam a vida mais prazerosa. 
Ao meu sogro Mário Francisco Spanghero, por me ajudar a encontrar na poesia e literatura aquilo que escapa à ciência e aos conceitos, o que permitiu dar forma a este trabalho. Juntamente com a sua esposa, Maria Antônia Sanchis, agradeço ainda às estimulantes discussões sobre tudo e, não menos importante, sobre o nada.

Ao Prof. Sérgio Barbosa que, de maneira insistente, sempre me fez lembrar que eu poderia seguir a carreira acadêmica.

Aos amigos do "Laboratório Discursivo: sujeito, rede eletrônica e sentidos em movimento" (El@dis-FFCLRP/USP), especialmente à Bia Prandi, Daiana de Oliveira Faria, Daniela Giorgenon, Dantielli Assumpção Garcia, Thaís Harumi Manfré Yado, pela amizade e afeto que nasceram durante esta etapa. Em especial, ao Gustavo Grandini Bastos, meu "irmão" de Doutorado, pela amizade e por tantas vezes ter me ajudado em momentos distintos. A vocês, minha gratidão.

À Débora L. Montezeli, por seu profissionalismo e por ter me encorajado a assumir novas posturas e a acreditar em tantos caminhos possíveis.

Ao casal Rosa e Omar Kenzo, amigos de longa data, pela ajuda em todos os momentos.

Aos funcionários e docentes do Programa de Pós-Graduação em Psicologia da FFCLRP/USP Ribeirão Preto, pela dedicação com que nos conduzem nesta fase de nossas vidas.

Ao Conselho Nacional de Desenvolvimento Científico e Tecnológico (CNPq), pelo financiamento desta pesquisa.

Aos meus gatos, Jung e Toddy, que com seus miados e estripulias fizeram com que eu tivesse momentos de ócio, bálsamos para a nossa consciência e existência.

Parafraseando Henry James (2013), quando em 1873 se despedia de Roma após cinco meses na cidade, não seria possível, em algumas linhas, poder sumariar, por tributo e homenagem, a minha experiência e os ganhos intelectual e pessoal, enfim, a experiência vivida durante o Doutorado. Tampouco conseguiria listar todos que esbarraram comigo e contribuíram de alguma forma para a construção deste trabalho. Mas espero que estejam todos guardados em lugares seguros da memória, e emergirão quando a vida, a ciência ou a arte os solicitarem. A tudo e a todos, meu agradecimento e gratidão! 
Os homens costumam julgar mais pelos olhos do que pelas mãos, uma vez que todos podem enxergar, mas poucos sabem saber sentir.

Nicolau Maquiavel

Somente as ideias que vivemos é que têm valor.

Hermann Hesse 


\section{RESUMO}

Sanches, R. D. (2018). Corpus Alienum: efeitos do discurso das novas dietas, corpo-projeto e mídia (Tese de Doutorado). Faculdade de Filosofia, Ciências e Letras de Ribeirão Preto, Universidade de São Paulo, Ribeirão Preto.

A pesquisa busca investigar e refletir, na perspectiva teórica da Análise do Discurso (Pêcheux; Orlandi), em interface com pesquisadores das Ciências Sociais, sobre o sujeito e os efeitos de sentido produzidos pelo discurso midiático de dietas e suas novidades, que promete resultados rápidos e fáceis na busca de um corpo muitas vezes irreal. A preocupação em perder peso tem aumentado e, segundo alguns psiquiatras, tornou-se um problema de grandes proporções. Neste processo de "construção do corpo", nos interessa o discurso produzido pela mídia atual e materializado em práticas sociais e condutas corporais. O corpus foi composto por revistas e sites que promovem as novas dietas, e que, além da publicação impressa, dispunham de versão digital com espaço para comentário dos leitores. A nossa hipótese é a de que o discurso midiático das novas modalidades de regime afeta a constituição da mulher e sua relação com o corpo na contemporaneidade. Esse discurso, com uma linguagem ancorada em simbolismos, promete que o novo (dieta, exercício) por si só, é e será sempre o melhor, mesmo com o surgimento de coisas novas em velocidade incompatível com a capacidade dos sujeitos de consumi-las e entendê-las em sua totalidade. As condições de produção do discurso das dietas são marcadas profundamente por alguns aspectos: o "texto da mídia", a linguagem publicitária (imagens e textos atuando em conjunto), a velocidade, a repetição, o consumo e a tecnologia. A dieta não deve ser analisada apenas como um produto, mas como um fenômeno discursivo que faz circular sentidos em uma ambiência midiática que opera em um cenário sócio-histórico, cultural e econômico-capitalista. A ideologia das dietas está atrelada ao mercado, que por sua vez interpela os sujeitos através da mídia, convocando-os a alcançarem patamares de excelência cristalizados em formatos corporais. O sujeito é interpelado a re(fabricar)-se a todo momento. O imperativo "sucesso" perpassa as formações ideológicas e seus discursos. Enquanto o discurso da boa forma interpela o sujeito convocando-o a ser mais ágil e rápido na busca do corpo-perfeito, o corpo da realidade testa seus limites deparando-se com sua fragilidade. É nesse processo que sentidos como os de beleza se constituem, através de um jogo de filiações históricas que os determinam, mas que jamais se estabilizam completamente. Nesse jogo, percebemos o funcionamento da ideologia legitimando o que deve ser compreendido como formato (imagem) do corpo contemporâneo. Os sentidos do discurso midiático das dietas e boa forma, ao enaltecer o corpo-projeto, menospreza o corpo-abjeto. O corpo-abjeto simplesmente é, enquanto o corpo-projeto está calcado em um devir, em um deve ser. A ideologia do mercado das dietas faz circular sentidos de um corpo-projeto que contrastam com a obsolescência do corpo da realidade, tomando-o como um objeto frágil e obsoleto pela gordura que carrega, pelo processo de envelhecimento e pelas doenças que o castigam. O sujeito é convocado a viver na encruzilhada entre a excelência imposta pelas ferramentas midiáticas e a imperfeição da realidade.

Palavras-chave: Discurso. Dietas. Novo e novidade. Corpo-projeto. Mídia. 


\begin{abstract}
The present research seeks to investigate and to reflect, at the interface of the theoretical perspective of Discourse Analysis (Pêcheux; Orlandi) and the Social Sciences researches, the subject and the effects of meaning produced by the media diets discourse and their novelties, which promises fast results and easy to find an often unreal body. Concern about weight loss has increased and, according to some psychiatrists, has become a major problem. In this process of "body building", we are interested in the discourse produced by the current media and materialized in social practices and corporal behaviors. The corpus was composed of magazines and sites that promote the new diets, and, had a digital version with space for readers'comments. Our hypothesis is that the mediatic discourse of the new diets modalities affects the constitution of the woman and her relation with the body in the contemporaneity. This discourse, with a language anchored in symbolism, promises that the new (diet, exercise) by itself, is and will always be the best, even if the emergence of new things occurs at a speed incompatible with the subjects' ability to consume and understand them in their totality. The production conditions of the diets' discourse are deeply marked by some aspects: the "text of the media", the advertising language (images and texts acting together), speed, repetition, consumption and technology. Diet should not be analyzed only as a product, but as a discursive phenomenon that circulates meanings in a mediatic environment that operates in a socio-historical, cultural and economic-capitalist scenario. The ideology of diets is linked to the market, which in turn challenges the subjects through the media, inviting them to reach levels of excellence crystallized in body shapes. The subject is called upon to re-fabricate himself at all times. The imperative "success" permeates ideological formations and their discourses. While the discourse of good shape challenges the subject by summoning him to be more agile and quick in the quest for the perfect body, the body of reality tests its limits by encountering its fragility. It is in this process that senses such as those of beauty are constituted through a set of historical affiliations that determine them, but never fully stabilize. In this game, we perceive the functioning of ideology legitimizing what must be understood as the shape (image) of the contemporary body. The senses of the diet mediatic discourse and good form, when uplifting the body-project, despise the body-abject. The body-abject simply is, while the body-design is set in a becoming, in a must be. The ideology of the diet market circulates the senses of a body-project that contrasts with the obsolescence of the real body, taking it as a fragile and obsolete object because of the fat it carries, the aging process and the diseases that punish it. The subject is convened to live at the crossroads between the excellence imposed by the media tools and the imperfection of reality.
\end{abstract}

Keywords: Discourse. Diets. New and novelty. Body-project. Media. 


\section{LISTA DE IMAGENS CAPITULARES}

Capa - Night Portrait Face Down (Lucian Freud, 1999-2000) - Recuperado em 10 de junho de 2016, de http://www.wikiart.org/en/lucian-freud/night-portrait-face-down2000

Introdução - Portrait on a White Cover (Lucian Freud, 2002-2003) - Recuperado em 10 de junho de 2016, de http://www.wikiart.org/en/lucian-freud/portrait-on-a-whitecover-2003

Capítulo 1 - Benefits Supervisor Sleeping II (Lucian Freud, 1995) - Recuperado em 20 de junho de 2016, de http://www.wikiart.org/pt/lucian-freud/benefits-supervisorsleeping-ii

Capítulo 2 - Annabel and Rattler (Lucian Freud, 1998) - Recuperado em 08 de janeiro de 2018, de https://uploads2.wikiart.org/images/lucian-freud/annabel-andrattler.jpg

Capítulo 3 - Naked Woman on a Sofa (Lucian Freud, 1984-1985) - Recuperado em 20 de junho de 2016, de http://www.wikiart.org/pt/lucian-freud/naked-woman-on-asofa-1985

Capítulo 4 - Standing by the Rags (Lucian Freud, 1988-1989) - Recuperado em 20 de junho de 2016, de http://www.wikiart.org/pt/lucian-freud/standing-by-the-rags1989

Um breve intervalo - The Painter's Daughter Ib (Lucian Freud, 1977-1978) Recuperado em 20 de junho de 2016, de http://www.wikiart.org/en/lucian-freud/thepainter-s-daughter-ib-1978 


\section{LISTA DE IMAGENS NO CORPO DO TEXTO}

Figura 1 - Recuperado em 1 de dezembro de 2014, de http://www.psicanaliseebarroco.pro.br/Imagens/rub3.jpga-e-reclama-nao-soueu.htm

Figura 2 - Recuperado em 18 de dezembro de 2017, de http://www.midiario.com/sites/default/files/monroe4.jpg

Figura 3 - Recuperado em 20 de novembro de 2017, de http://static.heloisatolipan.com.br/imagens//2017/01/1485785772070.jpg

Figura 4 - Recuperado em 20 de novembro de 2017, de http://ego.globo.com/famosos/noticia/2016/12/gabi-rippi-posa-com-o-bumbum-defora-para-capa-da-playboy-veja.html

Figura 5 - Recuperado em 20 de novembro de 2017, de http://ego.globo.com/famosos/noticia/2016/12/playboy-divulga-capa-com-modeloplus-size-fluvia-lacerda.html

Figura 6 - Recuperado em 18 de dezembro de 2014, de http://gente.ig.com.br/giselebundchen/

Figura 7 - Recuperado em 20 de junho de 2016, de https://www.google.com.br/search?q=alegria+e+tristeza+divertida+mente\&biw=16 $00 \&$ bih $=731 \&$ source $=$ lnms \& tbm $=$ isch $\&$ sa $=$ X \&ved $=0$ ahUKEwjj8cw5oLNAhUHjpAKHXADCgkQ_AUIBygB\#imgrc=6z5G-II6pxaJ6M\%3A

Figura 8 - Recuperado em 20 de junho de 2016, de http://mdemulher.abril.com.br/dieta/m-trends/conheca-dieta-que-fez-deborah-seccoemagrecer-11-kg-em-40-dias

Figura 9 - Recuperado em 20 de junho de 2016, de http://revistaquem.globo.com/QUEM-News/noticia/2015/04/gabriela-pugliesiexibe-barriga-sarada-e-da-dicas-de-como-sair-bonita-em-foto.html

Figura 10 - Recuperado em 5 de junho de 2016, de http://www.samsung.com.br/galaxys6 
Figura 11 - Recuperado em 5 de junho de 2016, de https://www.google.com.br/search?q=apple\&oq=apple\&aqs=chrome..69i57j69i60j6 9i59j69i6112j69i60.727j0j7\&sourceid=chrome\&ie=UTF-8

Figura 12 - Recuperado em 10 de janeiro de 2018, de https://www.google.com.br/search?q=revistas+de+dietas\&biw=1366\&bih=643\&sou rce $=$ lnms\&tbm=isch\&sa=X\&ei=RtOSVMrBFoeJsQSI94H4DQ\&ved=0CAgQ_AU oAQ

Figura 13 - Recuperado em 10 de janeiro de 2015, de http://www.folha.uol.com.br/

Figura 14 - Recuperado em 13 de janeiro de 2018, de https://mcdn.belezanaweb.com.br/image/upload/f_auto,fl_progressive,q_auto:best,w _800/v1/imagens/5/34542-complementar-1-4396103653025533742.jpg

Figura 15 - Recuperado em 2 de julho de 2016, de https://www.google.com.br/search?q=corpo+novo+vida+nova+livro\&espv=2\&sour

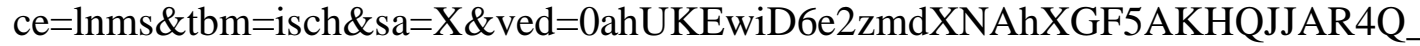
AUICSgC\&biw=1366\&bih=643\#imgrc=AS6IwjIfS4nxeM\%3 $3^{\text {a }}$

Figura 16 - Recuperado em 19 de agosto de 2013, de http://www.folha.uol.com.br/

Figura 17 - Recuperado em 5 de novembro de 2017, http://www.health.incommunseries.com/2015/11/bella-falconi-mostra-fotos-dagravidez.html

Figura 18 - Recuperado em 5 de novembro de 2017, https://www.moma.org/calendar/exhibitions/1517/installation_images/29?locale=em

Figura 19 - Recuperado em 8 de janeiro de 2017, de https://www.youtube.com/watch?v=kDhptBT_-VI

Figura 20 - Vitrine de uma loja de artigos esportivos em um shopping da cidade de São Paulo (arquivo próprio) 


\section{SUMÁRIO}

DAS BANCAS DE JORNAIS E DOS CORPOS: PAULISTAS NA PAULISTA

1 DO CORPO AO CORPUS: EFEITOS IDEOLÓGICOS DO CORPO PROJETO, MÉTODO, METODOLOGIA, SUJEITO E DISCURSO

1.1 Sobre efeitos ideológicos do corpo-perfeito (corpo-projeto)

1.2 Método e metodologia: um percurso investigativo

1.3 O sujeito do/no discurso midiático das dietas: a forma-histórica sujeitocapitalista (ou consumidor-consumido)

2 LIPOFOBIA, FORMAÇÃO DISCURSIVA DAS DIETAS, IMAGEM E IDEALIZAÇÃO CORPORAL

2.1 Lipofobia: efeitos midiáticos da perda de peso

2.2 Em busca da dieta perfeita (e do corpo-perfeito)

40

2.3 A imagem arde: dietas, corpo, memória, ideologia e discurso

2.3.1 A triste silhueta da tristeza: a ideologia da magreza mira o público infantil ...... 56

2.4 O mito do sucesso e da felicidade: Você. Só que melhor!

2.5 A submissão ao design do momento: o corpo magro

3 ALGUMAS QUESTÕES QUE NOS INCOMODAM, E (RE)CLAMAM POR INTERPRETAÇÃO

3.1 As condições de produção do discurso midiático das dietas: a naturalização de alguns sentidos e o silenciamento de outros

3.2 O texto da mídia

3.2.1 O texto midiático das dietas e boa forma: a exploração (linguística e visual) do ser vivo

3.2.2 Afine com a berinjela: a linguagem publicitária nos discursos das dietas (corpo-imperativo-condicional)

3.2.3 Nome próprio: efeitos de potência, facilidade, eficiência, rapidez

3.3 Acesso, logo emagreço: tecnologia, informação e celebridades 
4 O NOVO E A NOVIDADE

4.1 A ideologia do novo e da novidade: acúmulo e repetição

4.2 A nova dieta: a escalada da obsolescência (do corpo)

4.3 A velocidade da novidade: o sujeito-voraz

5 A ICONOGRAFIA DAS DIETAS: GEOMETRIZAÇÃO DO CORPO E EFEITOS DE COMPLETUDE (CORRA PARA SEMPRE)

5.1 A iconografia das dietas: a imagem do corpo-imagem

5.2 Corpo-projeto como o grande outro do sujeito: a geometrização do corpo e a homogeneização da pele

5.3 Expandir para lucrar (metáfora do elástico): "personal gestante", dietas e exercícios para antes e depois da gravidez (barriga ostentação)

5.4 Efeitos de completude: repetidas histórias de perfeição materializadas no corpo-imagem (corpo-celebridade)

5.5 Corra, sujeito corpo-perfeito, corra! 



\section{INTRODUÇÃO}

\section{DAS BANCAS DE JORNAIS E DOS CORPOS: PAULISTAS NA PAULISTA}

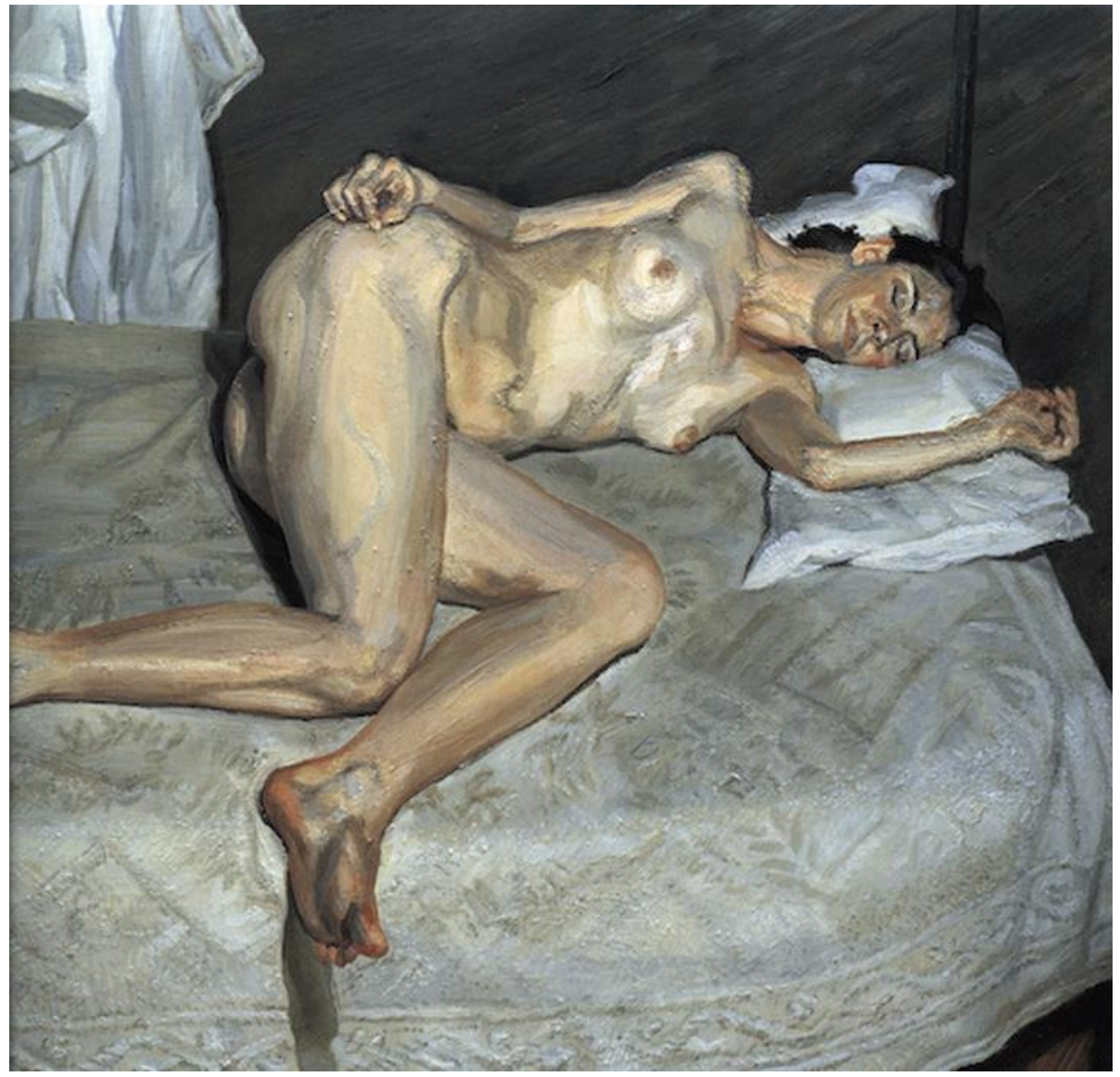

Portrait on a White Cover (Lucian Freud, 2002-2003)

Cada época, cada cultura, cada costume e tradição têm seu próprio estilo, têm sua delicadeza e sua severidade, suas belezas e suas crueldades, aceitam certos sofrimentos como naturais, sofrem pacientemente certas desgraças.

Hermann Hesse 
A cidade de São Paulo possui mais de 12 milhões de habitantes e uma densidade populacional de quase 8 mil habitantes por quilômetro quadrado. Parafraseando Carlos Heitor Cony (2004) ao descrever Tóquio, São Paulo é uma porção de edifícios cercada por edifícios por todos os lados. Ao caminhar por um de seus principais logradouros, a Avenida Paulista, é praticamente impossível não esbarrar (ou ser esbarrado) por um indivíduo. Observar os paulistas (e gente de diversos lugares do Brasil e do mundo) na Paulista é uma experiência singular. É um dos lugares mais plurais do mundo. Os frequentadores normalmente alternam dias e horários. Durante a semana e em horário comercial, é possível observar os executivos, homens usando terno e gravata e mulheres também trajando roupa social. Com vida noturna agitada, suas calçadas nunca ficam vazias. Aos fins de semana o público invariavelmente é mais diversificado. Aos domingos, quando a via é fechada normalmente das 10 às 18 horas, impedindo o trânsito de veículos, é fácil reparar nas famílias com crianças, casais, solteiros, grupos de amigos e toda sorte de pessoas. Se é possível identificar grupos (adolescentes, praticantes de algum esporte ou entusiastas de certos estilos musicais), o que não falta é variedade.

Uns dirão que a cidade é cosmopolita, outros, não tão universal assim. Um fato é inquestionável: a diversidade e a pluralidade dos corpos que circulam pela Avenida Paulista. Há uma multiplicidade de configurações e estilos corporais. Numerosos contornos, trajes, cor da pele, etnias, idades, cor e aparência do cabelo. O diferente impera. Urania Tourinho Peres, no posfácio da edição brasileira da obra Luto e Melancolia (2011), de Sigmund Freud, adverte que da mesma maneira que não encontramos dois corpos iguais, dois rostos iguais, também não encontramos duas almas, mentes ou psiquismos iguais. A pele que cada um habita é sui generis.

Em 2,7 mil metros de extensão, algumas bancas de jornais da Avenida Paulista mais parecem pequenas livrarias, dada a quantidade de publicações disponíveis (revistas, jornais, livros, guias de viagem). Ao observar as revistas sobre dietas e boa forma comercializadas nesses locais, a variedade corporal parece simplesmente desaparecer. As imagens dos corpos das publicações sobre esse tema parecem silenciar o diferente, em um discurso homogêneo e homogeneizador. As tentativas de agrupamento, afirma Peres (2011, p. 126), "serão sempre forçadas, manipulados e insuficientes". Esse é um dos pontos que tratamentos nesta tese. Dos sentidos do discurso das dietas e boa forma.

A primeira incursão na tentativa de compreender esse fenômeno ocorreu durante o Mestrado em Comunicação e Semiótica (PUC/SP), ao analisar como a relação entre imagemmáquina-mídia-corpo opera em nossa sociedade, criando imagens tecnicamente concebidas e teledistribuídas em uma velocidade jamais vista. Durante todo processo de desenvolvimento 
daquela pesquisa, dediquei-me aos estudos do discurso publicitário e midiático e suas consequências: como as imagens pré-concebidas e distribuídas pelos dispositivos (dos mais arcaicos aos revestidos de alta tecnologia e performance) moldam e modificam a percepção do corpo contemporâneo, afetando processos culturais e de subjetivação.

A gênese do presente trabalho é uma consequência da pesquisa realizada durante o Mestrado e tem, novamente, o corpo e a sua relação com contextos culturais como elementos centrais. Tanto no Mestrado quanto agora há alguns elementos que se entrelaçam: o primeiro deles é o corpo; o segundo, a mídia; o terceiro, o discurso midiático. O contexto a ser aqui estudado, porém, tem como foco reflexões acerca do sujeito contemporâneo: a relação entre o sujeito e o discurso contemporâneo das dietas. Motiva-nos indagar como a construção da subjetividade (entendida aqui como o enlaçamento do simbólico no homem - Mariani, 2006, p. 07) ocorre através dos efeitos do discurso do novo e da novidade no universo das dietas. A historiadora da Medicina Louise Foxcroft (2013) é enfática ao dizer que no último século a preocupação em perder peso aumentou e, segundo alguns psiquiatras, tornou-se um problema de graves proporções.

Durante o Mestrado, um dos tópicos que abordei foi o corpo-cabide, o corpo das modelos que se deixam assediar pelo paradigma estético necessário para alavancar suas carreiras. A preocupação em perder peso não se restringe ao mundo da moda, das modeloscabide ou a um nicho da sociedade. Os objetivos deste trabalho de pesquisa são investigar, compreender e refletir, na perspectiva teórica da Análise do Discurso (Pêcheux; Orlandi), em interface com autores e pesquisadores das Ciências Sociais, o sujeito e os efeitos de sentido produzidos pelo discurso midiático das dietas, que prometem resultados rápidos e fáceis na busca de um corpo muitas vezes irreal. Segundo Benedetti e Romão (2007, s/p), neste processo de "construção do corpo", nos interessa o discurso produzido pela mídia atual e materializado em práticas sociais e condutas corporais. Aqui, buscaremos focar na investigação da relação entre o sujeito-mulher e os sentidos produzidos pelo discurso midiático contemporâneo das novas dietas e suas novidades. Esse discurso se materializa em revistas e sites publicados sobre dietas e vida saudável. Na esteira das publicações, o que mantém esse discurso ativo e atraente é a criatividade dos profissionais que publicam notícias sobre dietas nas revistas impressas e virtuais. E isso tem reflexos diretos no imaginário contemporâneo sobre dietas e corpo, seja pela repetição ou pela redundância com que as notícias são veiculadas. Para ilustrar esse quadro, traçamos um paralelo entre a difusão das dietas e o uso disseminado da cocaína. Em seu livro “Zero Zero Zero", Roberto Saviano (2014) denuncia o uso e a disseminação da cocaína entre os diversos públicos e indivíduos de diferentes escalas sociais. Para chamar a atenção do leitor 
sobre a popularidade da cocaína nas mais distintas esferas da sociedade, Saviano inicia sua obra de uma forma bem redundante:

O sujeito sentado agora a seu lado no metrô cheirou para acordar hoje de manhã; ou o motorista do ônibus que te leva para casa porque quer fazer hora extra sem sentir dor na cervical. As pessoas mais próximas de você cheiram. Se não é seu pai ou sua mãe, se não é seu irmão, então é seu filho. Se não é seu filho, é seu chefe. Ou a secretária dele, que só cheira aos sábados pra se divertir. Se não é seu chefe, é a mulher dele que cheira para ir vivendo. Se não é a mulher, é a amante dele, a quem ele dá pó de presente, em vez de brincos e diamantes. Se não são eles, é o caminhoneiro que faz chegar toneladas de café nos bares da sua cidade e que não conseguiria aguentar todas aquelas horas de estrada sem pó. Se não é ele, é a enfermeira que está trocando o cateter do seu avô, para quem o pó deixa tudo mais leve, até mesmo as noites. Se não é ela, é o pintor que está pintando a sala da casa da sua namorada, que começou por curiosidade e depois se viu contraindo dívidas. Quem cheira está ao seu lado (2014, p. 11).

A questão das dietas é muito semelhante ao uso da cocaína descrito por Saviano pelo funcionamento imaginário de proximidade e constância com que ocorre - a prática das dietas parece ser um vício contemporâneo. Simulando a regularidade enunciativa e discursiva proposta por Saviano, arriscamos uma breve introdução ao nosso trabalho:

"A mulher que está sentada ao seu lado no metrô faz dieta. As filhas dela também querem emagrecer a todo custo. A sua mulher faz dieta, pois está descontente com seu corpo após o nascimento dos filhos. Se não a sua mulher, a sua filha. Ou sua cunhada. Ou sua amante. Ou alguém da sua família. Todas as celebridades fazem dieta, a não ser aquelas poucas cujo formato de corpo é tolerado como exceção. As mulheres que frequentam a academia do seu bairro fazem dieta. Para "trincar" o abdômen. Sua professora de yoga faz dieta. Ou a amiga dela, que não fica inibida quando vai almoçar com as amigas e pede ao garçom para esquentar sua marmita, cujos alimentos foram indicados pela nutricionista. Aliás, a nutricionista luta contra a anorexia há anos, pois se acha gorda - apesar do corpo magérrimo - e vive com medo de perder seus pacientes. A sua médica cardiologista também quer emagrecer, e vai para a academia mesmo após passar 12 horas trabalhando em um plantão médico. Se não é ela, é a enfermeira que também pretende emagrecer com a dieta que viu no programa de TV do último domingo. Se não é ela, é a criança que foi apelidada de "tristeza" por ser baixinha e gordinha, igual a personagem do filme "Divertida Mente". Seu chefe faz dieta. A mulher dele também faz dieta para conquistar o formato de corpo que tinha quando conheceu seu marido. Quem faz dieta está ao seu lado”. 
Todo mundo faz dieta de vez em quando - alerta Foxcroft (2013, p. 18): "e a maioria de nós é especialista na autoilusão que, sejamos honestos, é necessário para iniciar um regime rápido, e talvez excessivo, de perda de peso”. A diferença é que aquele que usa cocaína não sai alardeando o fato para ninguém. Procura escondê-lo. Já no caso das dietas não basta fazer, é preciso também dizer que está participando de uma (seja na divulgação boca a boca ou em redes sociais). Todos nós conhecemos alguém que fez ou está fazendo dieta. Quem nunca ouviu alguém próximo (ou nem tão próximo assim) comentar que está se submetendo a uma das centenas de dietas da moda?

A nutricionista Sophie Deram (2014) alerta que a procura por uma dieta milagrosa continua existindo porque recebemos o conceito errado que o corpo pode ser manipulado como cada um desejar, e isso seria um problema de educação e informação. Neste trabalho de pesquisa pretendemos justamente mostrar como o ambiente midiático das dietas e boa forma, ao produzir e fazer circular efeitos de sentidos sobre um determinado formato de corpo e como fazer para alcança-lo, têm a capacidade de educar o sujeito-leitor a aceitar certos axiomas provenientes desse discurso. Com o tempo, qual o efeito que esse discurso das novas dietas exerce sobre a mulher contemporânea?

Antes de continuarmos, precisamos esclarecer já no início que, nesta tese, não pretendemos apenas avaliar as capas ou o conteúdo das revistas e sites que se autointitulam "boa forma" ou "vida saudável", mas os efeitos de sentido resultantes do entrelaçamento do discurso das dietas e dos seus leitores com a história das próprias dietas, as condições sóciohistóricas, a forma sujeito produtor e consumidor, o mercado, a tecnologia, a mídia e o ambiente ou ambiência midiática que produz e faz circular o discurso das dietas e suas novidades. Esse trabalho não trata a dieta enquanto produto, mas como um fenômeno discursivo, que produz e faz circular sentidos em uma ambiência midiática. Fenômeno que acontece em um cenário sócio-histórico, cultural e econômico/capitalista. Qual a relação entre uma sandália, um automóvel, um videoclipe musical e uma nova dieta? Se enxergarmos esses objetos (tangíveis ou não) exclusivamente como produtos ou mercadorias, talvez não encontremos nenhuma semelhança. Mas se pensarmos que eles estão inseridos em um contexto capitalista e coexistem discursivamente, a proximidade é maior do que parece. É o que pretendemos mostrar no decorrer deste trabalho. Parafraseando Botton (2015), ao olharmos para este percurso, podemos arriscar que nossa busca, desde o início, foi e continua sendo o de estimular o sujeito que consome o discurso das dietas a perceber como nossa visão de mundo pode ser alterada depois de um mergulho no oceano discursivo do texto midiático das dietas e boa forma. 
Para tanto, esta tese foi desenvolvida através de um percurso, um trajeto que permitiu investigar os vestígios do discurso das novas dietas. É importante frisarmos que, como um trabalho científico, há começo e um fim. O sujeito e a linguagem e o sujeito da/na linguagem, atesta Orlandi (2005, p. 93), "precisa de um enunciado que acaba, de um texto com começo, meio, progressão e fim; ele tem necessidade também de imaginar que começa ou pode começar e terminar sua fala". Assim, as etapas que propusemos para esta rota, mesmo tendo começo e fim, estão interligadas. Os sentidos despontam a todo momento, e não isoladamente em um ou outro espaço. Os conceitos, as análises e as reflexões entrecruzam-se a todo momento. E, claro, não terminarão por aqui. Dada a constante movimentação e deslocamento de nosso objeto, não seria possível apartá-lo em análises isoladas. Um enunciado presente no discurso das novas dietas carrega consigo diversos efeitos de sentidos. Daí a necessidade de estabelecermos um percurso, que pode sempre ser revisitado.

Nesta jornada, propusemos cinco etapas. Na primeira delas (capítulo 1) já abordamos um conceito crucial deste trabalho: os efeitos ideológicos do que denominamos corpo-projeto. Neste ponto discorremos ainda sobre o método, a metodologia e o sujeito do/no discurso midiático das dietas (a forma histórica sujeito-capitalista). Na segunda etapa (capítulo 2), traçamos uma caminhada sobre a imagem e a memória do corpo feminino autorizado a circular no ambiente midiático contemporâneo, pensando discursivamente a lipofobia (o horror atual à gordura e aos corpos gordos) e os efeitos midiáticos da perda de peso. Neste momento, é fundamental marcarmos que nossa reflexão tem como alvo não qualquer imagem, mas a imagem enquanto discurso. Uma imagem que nos interessa pela sua eficácia simbólica, que possui uma arqueologia, um rastro discursivo que, quando o toca o real, arde.

No estágio seguinte de nosso caminhar (capítulo 3), focamos em algumas questões que, na esteira do pensamento da pesquisadora e professora Maria Onice Payer (2005), reclamam por interpretação. Essas questões incluem o texto da mídia, o texto midiático das dietas e boa forma, o entrelaçamento ideológico entre mercado, capitalismo, economia e globalização, a linguagem publicitária empregada nos enunciados sobre dieta e boa forma e os efeitos de sentidos dos nomes próprios das dietas, tecnologia, informação e celebridades. Na próxima fase (capítulo 4), propomos uma investigação sobre o funcionamento discursivo-ideológico do novo e da novidade, que não aparece unicamente no texto midiático das dietas e boa forma. Uma ideologia materializada discursivamente no acúmulo, repetição e velocidade de certos efeitos, que promove investindo de evidência a escalada da obsolescência do corpo, e exigindo do sujeito novas formas de se relacionar com as novidades tecnológicas que influenciam diretamente a vivência contemporânea. Antes de arriscarmos um concluir ou finalizar, 
apresentamos um quinto e último passo, que busca aprofundar o conceito de corpo-projeto como o grande outro do corpo, pensado a geometrização do corpo presente na iconografia das dietas, os efeitos de completude e a convocação dogmática que recai sobre a mulher atual (e o estar no mundo através de seu corpo). Em uma última parada, sugerimos um movimento de irromper para aproximar. Não se trata de uma conclusão ou finalização, mas de um intervalo reflexivo. Será que tocamos em alguma coisa?

Após essa breve introdução, podemos iniciar nossa caminhada na tentativa de investigar e compreender mais sobre essa prática discursiva das dietas, "essa reversibilidade entre social e linguageiro, a formação discursiva e o texto" (Azevedo, 2013, p. 38). Em especial o texto midiático, que aqui pretendemos nos debruçar, analisando um corpus (superficialidade significante) de textualidades relacionadas a certas formações ideológicas e práticas sociais. Não temos a presunção de apontar um conjunto de regras ou fixar um manual de "emagrecimento sem dieta" ou, ainda, de fazer "apologia à gordura". Ainda que soe uma ousadia, pretendemos, como Pêcheux (2009), fazer "uma crítica à afirmação do óbvio" presente no discurso midiático das dietas. Pretendemos provocar um estranhamento. Você já fez dieta? Esperamos que, ao final deste percurso, quem já vivenciou ou pretende iniciar alguma prática para emagrecer possa refletir sobre as armadilhas presentes no discurso midiático das práticas de emagrecimento. 


\section{Capítulo 1}

\section{DO CORPO AO CORPUS: EFEITOS IDEOLÓGICOS DO CORPO-PROJETO, MÉTODO, METODOLOGIA, SUJEITO E DISCURSO}

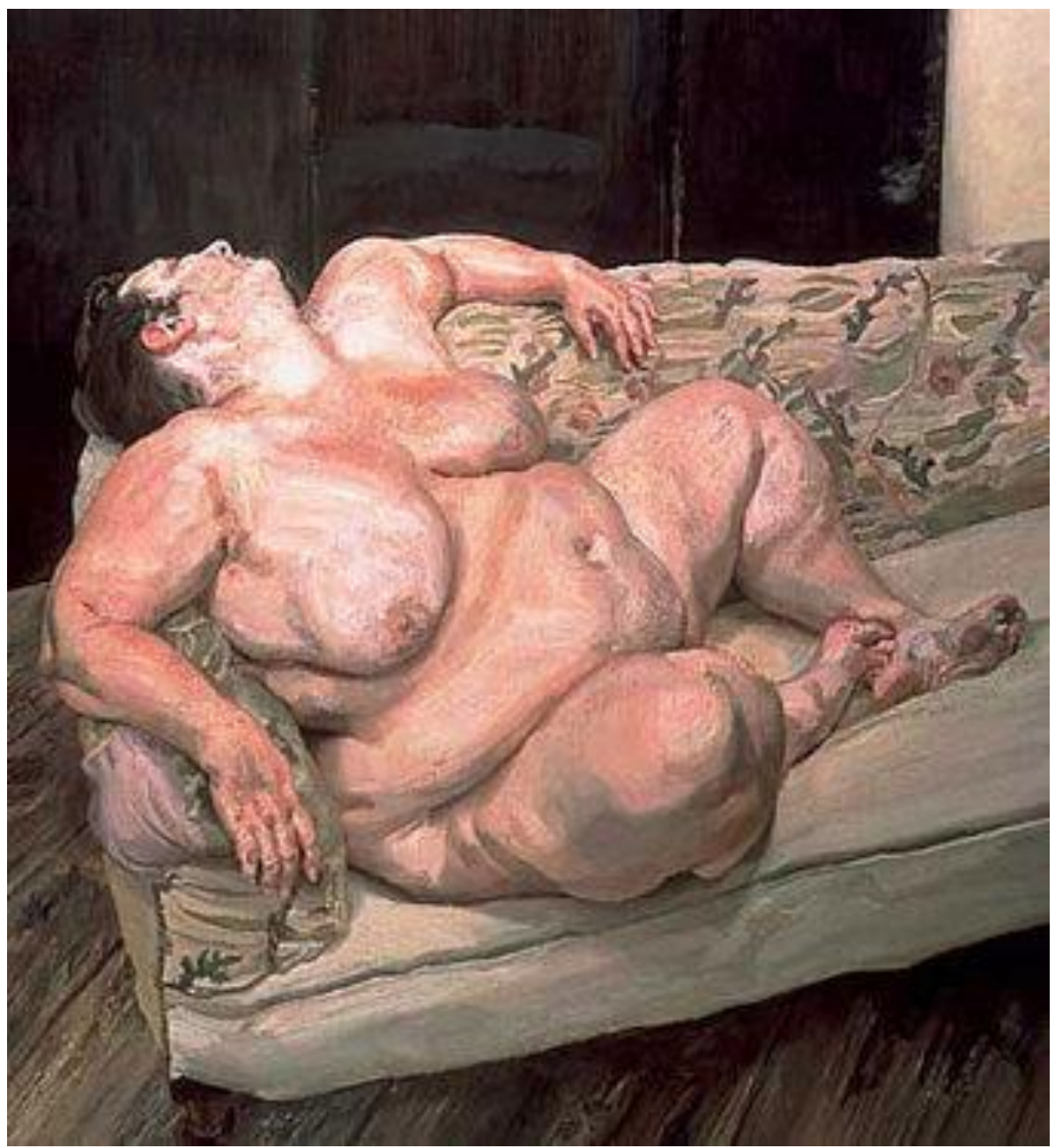

Benefits Supervisor Sleeping II (Lucian Freud, 1995)

Não possuímos nem o corpo, nem uma verdade - nem sequer uma ilusão. Somos fantasmas de mentiras, sombras de ilusões, e a nossa vida é oca por fora e por dentro. Conhece alguém as fronteiras à sua alma, para que possa dizer - eu sou eu? Mas sei que o que eu sinto, sinto-o eu. 


\subsection{Sobre efeitos ideológicos do corpo-perfeito (corpo-projeto)}

A palavra "corpo" (do latim corpu) tem no dicionário uma série de significados, podendo representar "tudo o que tem expressão e forma", "a estrutura física do animal” ou "o cadáver humano". Mesmo abarcando vários significados diferentes, o corpo que pretendemos trabalhar nesta tese não está dicionarizado. Enquanto corpo empírico, ele é apenas carne (Orlandi, 2012a). O que nos interessa aqui vai "além da simples carne e simples unhas", como atestou Drummond (2004), e nos impulsiona a investigar o corpo simbólico, produzido por um processo que é um processo de significação, um corpo interpelado, que não pode ser pensado sem a materialidade, a história e os processos da vida social e prática; portanto, o corpo não pode ser pensado sem a ideologia.

Na perspectiva da Análise do Discurso, teoria franco-brasileira que irá embasar este trabalho, a ideologia designa o que é o que deve ser, produzindo efeitos de evidência sobre o mundo e naturalizando um uso social tido como aceito para o hábito e o modo de inscrição do corpo. A ideologia é entendida como um mecanismo de produção de evidências que determina como as coisas são e como não são (Pêcheux, 2009). Segundo Mariani (1998), é um mecanismo imaginário através do qual se coloca para o sujeito, conforme posições sociais que ocupa, um dizer já dado como óbvio; um sentido que lhe parece evidente como, por exemplo, o formato magro do corpo que circula na mídia. Para Orlandi (2009), a ideologia é a condição para a constituição do sujeito e dos sentidos. Todo corpo necessita de um discurso que lhe dê uma forma, um desenho, uma possibilidade de se inscrever em uma determinada época e em uma determinada sociedade. E todo discurso necessita de um corpo. O discurso é a "palavra em movimento, prática de linguagem [...] é o lugar em que se pode observar essa relação entre língua e ideologia, compreendendo-se como a língua produz sentidos por/para os sujeitos" (Orlandi, 2009, p. 15). Não há história ou ideologia ou língua ou simbólico sem sujeito; portanto, não há história ou ideologia ou língua ou simbólico sem o corpo.

A busca por um determinado formato do corpo não é algo novo. A percepção que temos do corpo muda ao longo do tempo, e cada período e cultura têm sua obsessão com uma forma corporal específica. "Formas corporais desejáveis têm especificidades culturais, e os preconceitos se acumulam sobre aqueles cujos corpos são diferentes" (Foxcroft, 2013, p. 14). Esse corpo - argumenta Milanez (2009) - é produto de uma subjetivação marcada por uma alteridade constitutiva que abarca um conjunto de imagens e textos que nos remete a uma forma 
temporal determinada. O corpo é o meio pelo qual a conversão a nós mesmos se dá a ver, estabelecendo uma relação de si para consigo (Milanez, 2009).

No universo midiático das dietas, o corpo da mulher contemporânea é discursivizado como um corpo perfeitamente magro, o que aqui denominaremos "corpo-projeto", intrinsicamente ligado a uma beleza extraordinária naturalizada pela mídia. O corpo-projeto é um padrão de corpo gerado artificialmente por programas de computador e transformado em imagens idealizadas de uma perfeição insuperável. Juntamente com uma linguagem trabalhada para persuadir o sujeito-leitor (como veremos mais adiante), ele traz consigo a ilusão de poder ser imitado, alcançado. E na autoilusão de tentar a todo custo modelar o corpo físico em algo metafísico, que não corresponde à realidade, o sujeito é exposto a uma séria de armadilhas sedutoras provenientes de um discurso que se materializa em textos e imagens. Discurso que interpela ideologicamente o sujeito a fazer todo esforço para alcançar o corpo propagado em revistas e sites. Alguns dos artifícios disponibilizados pela mídia para que o sujeito modele seu corpo e alcance o arquétipo imposto pelo corpo-projeto são as novas dietas e suas supostas novidades.

Para pensar a relação entre o corpo feminino e o discurso midiático das novas dietas e suas supostas novidades, adotamos os pressupostos analíticos, metodológicos e teóricos da Análise do Discurso (AD) franco-brasileira. Em interlocução com autores e pesquisadores das Ciências Sociais, procuramos refletir sobre os efeitos de sentidos produzidos pelo discurso midiático das novas dietas, que prometem resultados rápidos e fáceis na busca de um corpo muitas vezes irreal. Para tanto, adotamos as noções conceituais de Sujeito, Discurso, Ideologia e Formação Discursiva (FD) provenientes da Análise do Discurso.

A nossa hipótese é a de que o discurso midiático contemporâneo das novas modalidades de regime afeta a constituição do sujeito-mulher e sua relação com o corpo na contemporaneidade.

\subsection{Método e metodologia: um percurso investigativo}

O método em Análise do Discurso (AD) é fundamentado pela singularidade da teoria (Giorgenon, 2016), da constituição do corpus e das técnicas de análise. A AD permite fazer uma reflexão sobre as condições de produção e apreensão dos sentidos de textos produzidos em diferentes campos, almejando compreender o modo de funcionamento, os princípios de 
organização e as formas em que os sentidos são produzidos. Ao escolher a AD como referencial teórico para investigar e compreender como a linguagem midiática das novas dietas (com seus métodos e produtos de emagrecimento) e sua relação com o sujeito, pretendemos traçar um percurso que, segundo Minayo (2008), torna possível a objetivação de um tipo de conhecimento que tem como matéria prima opiniões, crenças, valores, representações, relações e ações humanas e sociais sob a perspectiva dos atores em intersubjetividade.

Pela Análise de Discurso, podemos compreender as regularidades discursivas produzidas em dadas condições sócio-históricas, ou seja, investigar como se estabelecem as relações do sujeito com o corpo e o discurso das dietas na atualidade. A expectativa é que, após um percurso investigativo sobre a relação do sujeito contemporâneo com os corpos discursivizados pelo ambiente midiático das dietas, possam emergir alguns aspectos que permitam entender como o entrelaçamento sujeito/corpo/mídia/dietas produz sentidos por/para a mulher na atualidade. Segundo Orlandi (2009), a Análise do Discurso busca construir um dispositivo de interpretação que tem como característica colocar o dito em relação ao não dito; é investigar o outro lugar do enunciado, que está sempre suscetível de ser/tornar-se outro. É nesse ponto que a $\mathrm{AD}$ permitirá compreender o funcionamento do discurso das dietas (os "novos recursos" e as "novidades"), investigando um discurso que, ancorado em imagens tecnicamente elaboradas e em uma linguagem com indícios publicitários, circula na mídia. Uma linguagem em permanente mutação, reconstruída, recortada, que se desloca ideologicamente e se oferece para análise:

Pêcheux, partindo de uma crítica ao estado das ciências humanas e sociais nos anos sessenta, estabelece o discurso como objeto de uma disciplina de entremeio, cujo objetivo maior é estabelecer uma reflexão sobre sujeito e sobre funcionamentos linguístico-históricos, visando a uma compreensão da interpelação ideológica constitutiva da produção de sentidos nos sujeitos (Mariani, 2003, p. 57).

A AD é o dispositivo teórico necessário para que o analista possa trabalhar no jogo, no entremeio da descrição e interpretação, já que "não há análise de discurso sem a mediação teórica permanente". É assim, resume Orlandi (2009), que o analista de discurso "encara" a linguagem. A linguagem que aqui pretendemos confrontar constitui-se a partir de práticas sociais de nossa época, nasce dos dispositivos tecnológicos e midiáticos disponíveis aos sujeitos, e usa diversos recursos para produzir o discurso do novo e da novidade no mercado de emagrecimento - apesar das loucuras e torturas dos regimes serem práticas antigas na história da humanidade. A palavra discurso, conforme explica Orlandi (2009), etimologicamente tem 
em si a ideia de curso, de percurso, de correr por, de movimento. O conceito de discurso tem como premissa os efeitos de sentidos entre interlocutores (Pêcheux, 2009). "É o lugar em que se pode observar essa relação entre língua e ideologia, compreendendo-se como a língua produz sentidos por/para os sujeitos" (Orlandi, 2009, p. 17).

Uma vez que a delimitação do corpus não segue critérios empíricos, mas teóricos, procuramos perscrutar o discurso (materialidade significante) das novas dietas, recortando fragmentos textuais e imagens ${ }^{1}$ no corpus que agora delimitamos:

- Publicações impressas:

1. Boa Forma;

2. Corpo a Corpo;

3. Dieta Já;

4. Shape Brasil²;

5. Women's Health.

- Sites:

6. boaforma.abril.com.br;

7. corpoacorpo.uol.com.br;

8. dietaja.uol.com.br;

9. mdemulher.abril.com.br.

10. revistashape.uol.com.br;

11. revistawomenshealth.com.br.

A escolha dos periódicos tem como base três fatores: a abordagem das dietas para o público feminino e suas novidades; o tempo de permanência das publicações no mercado e, além da edição impressa, dispor de versão on-line com espaço para comentário dos leitores e internautas. A revista Boa Forma (Editora Abril) é publicada há 32 anos. Já as revistas Corpo a Corpo e Dieta Já (ambas da Editora Escala), são publicadas há 31 e 22 anos, respectivamente.

\footnotetext{
${ }^{1}$ Como veremos logo abaixo, este trabalho de pesquisa propõe um traçado investigativo, um caminho a ser percorrido sobre a questão das dietas e suas novidades. Para facilitar o encadeamento das ideias, optamos por discorrer sobre a questão da imagem no Capítulo 2. Além da análise das imagens que circulam em nosso corpus, mostraremos qual o conceito de imagem será mobilizado em nossa pesquisa. Como uma espécie de incêndio, não é possível falar das imagens sem olhar para suas cinzas (Didi-Huberman, 2012).

${ }^{2}$ As publicações impressas foram coletadas durante 12 meses (janeiro a dezembro de 2015), o que não ocorreu com a Shape Brasil, cuja circulação foi interrompida em maio de 2015 (edição n. 69). Decidimos manter o periódico em nosso corpus por se tratar de uma importante e interessante amostra do discurso das dietas.
} 
A Revista Shape (Editora Alto Astral) é a mais recente do mercado brasileiro, sendo publicada há 5 anos e cuja circulação foi interrompida em maio de 2015. O site "mdemulher" faz parte do braço digital do Grupo Abril, que é um dos maiores conglomerados de comunicação da América do Sul. Optamos em trabalhar com revistas e sites sobre "boa forma" e "vida saudável" justamente por trazerem periodicamente um novo manual para emagrecer. A coleta do material para análise foi realizada da seguinte forma:

- edições impressas: de junho de 2014 a dezembro de 2017, mensalmente ou de acordo com a periodicidade de cada publicação;

- versões digitais: de junho de 2014 a dezembro de 2017;

- selecionamos os discursos midiáticos e os comentários dos leitores e sujeitosinternautas que, de uma forma ou de outra, façam referência: 1. às novas dietas e suas novidades; 2. à exaltação do corpo idealizado pela mídia; 3. ao endosso das celebridades; 4. à repetição e à velocidade atreladas ao ato de emagrecer.

- durante 12 meses, de janeiro a dezembro de 2015, as publicações impressas foram adquiridas mensalmente; antes e depois desse período, adquirimos apenas as publicações que, por trazerem algum enunciado passível de análise, passaram a compor nosso corpus.

A delimitação do corpus segue o pressuposto de que tanto a sua construção quanto a sua análise estão intimamente ligadas, e decidir o que faz parte do corpus já é decidir acerca das propriedades discursivas (Orlandi, 2009). Nesse aspecto, reforçamos a questão da "montagem discursiva" deste trabalho, ou seja, nas categorias elencadas acima serão analisados os discursos observando sua constituição, formulação e circulação (Orlandi, 2005) e os diferentes gestos de leitura que constituem os sentidos dos textos e imagens submetidos à análise. "O que nos interessa não são as marcas em si mas o seu funcionamento no discurso. É este funcionamento que procuramos descrever e compreender" (Orlandi, 2009, p. 65).

Dependendo do recorte teórico-analítico efetuado pelo analista, diferentes caminhos podem ser percorridos, diz Mittmann (2007):

Não fazemos uma descrição do texto, mas uma teorização sobre o discurso, ou seja, tomamos o texto como unidade linguística para análise do funcionamento do discurso e de suas condições históricas de produção/leitura. E porque, nesta teorização, não efetuamos uma análise exaustiva, tentando dar conta de todos os aspectos envolvidos, mas trabalhamos profundamente sobre alguns aspectos discursivos inter-relacionando arqueologicamente noções teóricas pertinentes. Disso, vale destacar que, como pesquisadores, acionamos nossa habilidade de arquivistas, buscando, resgatando, selecionando textos. Nesta seleção, optamos por um campo discursivo e/ou um tema (p. 01 - grifos nossos). 
Nesta tese optamos por um caminho cujo encadeamento das ideias e reflexões só foi possível graças ao entrelaçamento entre objeto de pesquisa, teoria e análise. Em nossa pesquisa, a principal questão é: qual a relação do corpo feminino, portanto, da mulher enquanto forma histórica sujeito-capitalista, com a ideologia do universo midiático das dietas e suas supostas novidades? Quais os sentidos e os efeitos do novo e da novidade? Quais as ideologias e as práticas discursivas que se impõem sobre a constituição biológica desses mesmos sujeitos?

Para tentar responder a essas questões, os recortes não serão analisados em um único capítulo, hermeticamente, mas desde o início de nosso percurso, fornecendo subsídios para reflexões posteriores, ou seja, em consonância com a teoria discursiva teoria e análise se afetam e constroem juntas. Também as reflexões e os caminhos argumentativos não estarão completamente vedados, mas sempre em correlação com o que o antecedem e o precedem. Nesse roteiro investigativo, a mobilização dos conceitos teóricos ocorrerá do mesmo modo: não apenas em um ou outro capítulo, mas sempre que necessário, traçando um mapa (de diversos caminhos e possibilidades) dos vestígios e sinais apresentados pelo nosso objeto de análise, já que "das muitas direções que se expõem à nossa frente, nosso olhar vai definindo um caminho. Colocamos, então, a lupa diante do olho curioso, atento e determinado (nos dois sentidos), e começamos o trabalho de investigadores" (Mittmann, 2007, p. 01). Da mesma forma, as indagações e os problemas de pesquisa aparecerão no decorrer do texto, aguçando a reflexão e apontando possíveis respostas e argumentos que compõem as estradas/escolhas deste percurso de investigação.

Uma vez que optamos por um recorte metodológico que abrange principalmente o corpo feminino, as publicações impressas ou digitais voltadas para o público masculino não serão objetos de análise. Não faz parte do nosso corpus, por exemplo, a revista Men's Health. Entendemos que o discurso midiático das dietas voltado para os homens apresenta semelhanças, mas, também, diferenças e singularidades em relação ao discurso direcionado às mulheres. Essas peculiaridades demandariam outros olhares, além da mobilização de conceitos específicos, podendo ser objeto de novas e desafiadoras pesquisas.

Reforçando o que já dissemos anteriormente, os enunciados das dietas e os respectivos comentários dos leitores serão interpretados levando em consideração (Orlandi, 2009): o modo de funcionamento, os princípios de organização e as formas em que os sentidos são produzidos. A partir dos recortes selecionados, analisaremos os enunciados dos discursos (materialidade significante), agrupando os textos e as imagens que dialogam entre si; os comentários do sujeito-leitor e suas materialidades linguísticas, repetições e sequências discursivas que façam alusão ao discurso das dietas e suas novidades; as formas de subjetividade presentes nos 
discursos das dietas e nos comentários dos sujeitos-internautas, observando os significados e os efeitos de sentido produzidos através da linguagem e das imagens que circulam em conjunto com tais enunciados. Não estamos nos referindo apenas à interpretação dos enunciados, mas trabalhar no limite dessa interpretação (Orlandi, 2009). Aliás, em relação às imagens e aos textos, recordemos Didi-Huberman (2012), para quem, do ponto de vista antropológico, é impossível opor as imagens e as palavras, já que todos juntos formam um tesouro ou uma tumba da memória. Desde muito cedo, argumenta Botton (2015, p. 11), "somos ensinados a apreciar a força das imagens e das palavras".

Ainda sobre os recortes linguísticos, nosso corpus de análise oferece uma grande quantidade de informação (superficialidade significante) passível de análise. Alguns recortes possibilitariam, em um único capítulo, uma análise exaustiva de vários aspectos inerentes ao discurso das novas dietas. Optamos, contudo, por analisar certos aspectos em determinados recortes e outros detalhes em novos enunciados. Fizemos essa escolha para facilitar o encadeamento das análises e reflexões, além de tornar o texto o mais didático e coerente possível. Acreditamos que a análise exaustiva de um enunciado em um único capítulo demandaria um esforço significativo do leitor, o que poderia comprometer a observação dos diversos ângulos que compõem nosso objeto de pesquisa. Caso optássemos por alguns poucos enunciados, poderíamos privar o leitor de conhecer um aspecto crucial do discurso das dietas: a repetição e a homogeneização. O discurso midiático das dietas é insistente em promover certos sentidos, em detrimento de tantos outros possíveis, em uma mecânica exaustivamente repetitiva.

É importante frisar que durante o desenvolvimento da pesquisa, fatos sobre o tema iam surgindo - acontecimentos que, por sua vez, produziram discursos, discursividades e sentidos. Portanto, além dos registros que selecionamos em nosso corpus, suscitamos outras materialidades que nos ajudassem a compreender o fenômeno social-midiático das dietas e boa forma, como um filme, uma campanha publicitária exposta em uma loja de um shopping, um videoclipe ou uma lei. São materialidades que surgiram durante nosso caminho trazendo à tona aspectos importantes sobre o tema. A lei sobre as imagens retocadas na França, o filme Divertida Mente, o videoclipe da cantora Anitta. Mesmo não fazendo parte do corpus, mostraram-se não menos significantes para esta tese. São eventos dispostos no mundo, circulam na ambiência midiática e produzem sentidos sobre o assunto. Estamos convictos de que, ao mobilizar tais materialidades, fizemos um exercício de conjugar e problematizar o fazer científico com a práxis vigente. Como veremos no decorrer desta pesquisa e conforme salienta Orlandi (2012b, p. 25), “o corpo do sujeito é um corpo ligado ao corpo social”. Portanto, uma 
pesquisa sobre temas relacionados ao corpo não poderia ser indiferente ao mundo e aos acontecimentos que o cercam.

Considerando que uma tese não tem condições de esgotar um assunto, é impossível visualizar todos os ângulos de um objeto. Alguns continuam escondidos, prontos para serem descobertos, interpretados. Neste percurso, optamos por algumas direções. Qualquer escolha implica, necessariamente, em privilegiar certos aspectos em detrimento de outros. Esperamos, leitor, que possamos caminhar juntos, e que o trajeto oriundo de nossas escolhas possa ajudálo a compreender como o universo midiático das novas dietas e boa forma produz sentidos nos dias atuais. E quais aspectos culturais, econômicos, sociais e midiáticos conseguimos trazer à tona ao observar e investigar um fenômeno tão abrangente quanto o discurso das dietas.

Todos esses aspectos serão observados e analisados levando-se em conta as condições de produção do discurso das dietas, nas quais elencamos alguns itens que efetivamente nos incomodam na atualidade e são imprescindíveis para a nossa trajetória: o "texto do mercado" ou "texto da mídia", a publicidade e sua linguagem (imagens e textos atuando em conjunto), o consumo e a tecnologia. Daí a importância, como reforça Mittmann (2007), de inter-relacionar noções teóricas pertinentes, já que nosso objeto de pesquisa está inserido em um universo complexo composto por aspectos comunicacionais, sociais, econômicos, culturais e de saúde.

Pretendemos também compreender a relação entre o sujeito e as formações ideológicas e discursivas que acabam por constituí-lo, de onde resultaria uma identidade imaginária. Tanto os sites quanto as revistas de "boa forma" que trazem reportagens sobre as últimas novidades no mundo das dietas permitirão investigar a produção de sentidos para os sujeitos que compram, consomem, produzem e reproduzem informações sobre procedimentos para emagrecer. Temos, desse modo, a exposição de um mosaico de várias vozes emendadas de modo contínuo a fazer (des)enrolar um imenso pergaminho eletrônico onde estão marcadas a voz do sujeito-blogger e as outras tantas vozes de sujeitos navegadores (Ferrarezi, Romão e Pacífico, 2012, s/p). Pretendemos, assim, investigar o sujeito que se identifica com as novidades propagadas pelos discursos das dietas, ou seja, se identifica com as formações ideológicas e discursivas que acabam por constituí-lo, de onde resultaria uma identidade imaginária. Um sujeito discursivo, incompleto tal qual a linguagem que o constitui, interpelado ideologicamente e, acima de tudo, desejante. Investigar o sujeito no discurso contemporâneo das dietas é fazer um exercício de teorização sobre uma ordem discursiva, que supomos ter se disseminada a ponto de suspeitarmos de um funcionamento social específico. Essa especificidade estaria na prática cultural contemporânea do sujeito que consome os efeitos do novo e da novidade do mercado das dietas. 
Vamos nos ater a cada um dos itens que descrevemos acima, porém sabemos que são pontos que se entrelaçam, atuando sob um grande guarda-chuva composto pelas formações social, ideológica e discursivas do universo das dietas. Através da AD será possível compreender o modo de funcionamento desse discurso no contex to contemporâneo, observando as diferentes materialidades significantes face ao mesmo processo discursivo.

\subsection{O sujeito do/no discurso midiático das dietas: a forma histórica sujeito-capitalista (ou consumidor-consumido)}

Qual é o sujeito que produz e reproduz a ideologia das novas dietas ou do mais recente método de emagrecimento? Para responder a essa questão, em um primeiro momento, abordaremos o conceito de sujeito para a AD. A Análise do Discurso introduz no centro de seu escopo teórico a noção de sujeito, e para entendermos melhor esse conceito, começamos por aquilo que ele não é: descrição física, forma empírica, categorias regidas pela cor da pele, classe social, idade, etnia, tampouco o sujeito afetado pelo afã de assenhorar-se conscientemente de suas palavras, capaz de geometrizar o seu dizer em equações pura e logicamente controláveis (Romão, 2009). Nesta tese não nos referimos ao sujeito individual, empírico ou quantificável, mas ao sujeito do/no discurso midiático das dietas. "Consideramos que o sujeito é um efeito de linguagem, uma 'posição' entre outras” (Ferrarezi, Romão, \& Pacífico, 2012, p. 247).

O sujeito da Análise do Discurso não é o sujeito empírico - sustenta Garcia e Sousa (2014) - mas a posição sujeito projetada no discurso: há em toda língua mecanismos de projeção que permitem passar da situação sujeito para posição-sujeito no discurso. "Portanto, não é o sujeito físico, empírico que funciona no discurso, mas a posição sujeito discursiva" (Garcia \& Sousa, 2014, p. 2). Atravessado pela linguagem e pela história sob o modo do imaginário (Orlandi, 2009), o sujeito é afetado pela língua e pela história, pois se não sofrer os efeitos do simbólico, ou seja, se ele não se submeter à língua e à história, ele não se constitui, não fala e não produz sentidos.

Após a definição do conceito de sujeito, passamos para uma segunda etapa: a formasujeito, maneira pela qual o sujeito do discurso se identifica com a Formação Discursiva que o constitui. Assim, explica Pêcheux (1997, p. 161), “os indivíduos são ‘interpelados’ em sujeitosfalantes (em sujeitos de seu discurso) pelas formações discursivas que representam 'na linguagem' as formações ideológicas que lhes são correspondentes”. Esta identificação baseia- 
se no fato de que os elementos do interdiscurso, ao serem retomados pelo sujeito do discurso, acabam por determiná-lo3 . O interdiscurso - explica Orlandi (2009, p. 31) - “disponibiliza dizeres que afetam o modo como o sujeito significa em uma situação discursiva dada". Ou seja, o interdiscurso é o conjunto das Formações Discursivas que se inscreve na constituição do discurso, trabalhando a ressignificação do sujeito sobre o já dito. A observação do interdiscurso nos permite remeter um determinado dizer "a toda uma filiação de dizeres, a uma memória, e identificá-lo em sua historicidade, em sua significância” (Orlandi, 2009, p. 32). Também chamado de sujeito do saber, sujeito universal ou sujeito histórico de uma determinada formação discursiva, a forma-sujeito é responsável pela ilusão de unidade do sujeito. Faz-se necessário, assim, examinar as propriedades discursivas da forma-sujeito como "sujeito do discurso":

\begin{abstract}
A interpelação do sujeito indivíduo em sujeito de seu discurso se efetua pela identificação (do sujeito) com a formação discursiva que o domina (isto é, na qual ele é constituído como sujeito): essa identificação, fundadora da unidade (imaginária) do sujeito, apoia-se no fato de que os elementos do interdiscurso (sob sua dupla forma, descrita mais acima, enquanto "pré-construído" e "processo de sustentação") que constituem, no discurso do sujeito, os traços daquilo que o determina, são re-inscritos no discurso do próprio sujeito (Pêcheux, 2009, p. 150 - grifos nossos).
\end{abstract}

Retornando à questão: qual é o sujeito que produz e reproduz a ideologia das novas dietas? Para responder a essa questão, nosso percurso teórico-investigativo aponta para um terceiro aspecto: o sujeito ao qual nos referimos, explica Orlandi (2009), é a forma-histórica sujeito-capitalista. "Mesmo havendo um deslocamento nas formas como o capitalismo se pratica e estabelece suas relações de poder, ainda assim continuamos no domínio ideológico do capitalismo" (Orlandi, 2009, p. 15). O sujeito é constituído a partir relação com o outro, nunca sendo fonte única do sentido, tampouco elemento onde se origina o discurso ${ }^{4}$. Se, para a Análise do Discurso, "o indivíduo é interpelado em sujeito pela ideologia para que se produza o dizer" (Orlandi, 2005, p. 46), sustentamos que a forma sujeito-capitalista segue o mesmo princípio: o indivíduo é atravessado e constituído em sujeito pelo discurso midiático do mercado (Payer, 2005).

3 Glossário de termos do discurso. Recuperado em 24 de maio de 2016, de http://docslide.com.br/documents/glossario-de-termos-do-discurso.html. Discutiremos mais sobre as variadas formas-sujeito da atualidade no decorrer do trabalho.

4 Glossário de termos do discurso. Recuperado em 24 de maio de 2016, de http://docslide.com.br/documents/glossario-de-termos-do-discurso.html 
Cada um à sua maneira, vários autores procuram definir a forma-histórica sujeitocapitalista ou forma sujeito-consumidor-moderno (que abarca as demais formas-sujeito sob o funcionamento do sistema capitalista e todas as suas implicações na vida prática e social). E o que move a forma sujeito-capitalista é o sucesso (como veremos mais adiante). "Homem cultural automático" (Becker, 2007, p. 100), "homem médio ideal” (Morin, 2005, p. 36), “consumidor-tipo" (Gorz, 2005, p. 48) consumidor "consumido" (Barber, 2009; Moulian, 1999; Flusser, 1972) ou o sujeito que opera o "modo consumista" Bauman (2005, p. 70) são algumas das definições. O "homem cultural automático" é

\begin{abstract}
Homem confinado pela cultura, escravo dela, que imagina ter uma identidade ao pagar o prêmio de seu seguro, que pensa ter controle de sua vida quando acelera seu carro esporte ou usa a sua escova de dente elétrica [...] O homem acalentado pelas rotinas diárias de sua sociedade, contente com as satisfações que ela lhe oferecia: no mundo de hoje, o carro, o shopping, as férias de duas semanas no verão. $\mathrm{O}$ homem que está protegido pelas alternativas seguras e limitadas que sua sociedade lhe oferece e, se não tirar os olhos de seu caminho, poderá levar a vida com uma certa segurança insípida (Becker, 2010, p. 100101).
\end{abstract}

É aquele que, de certo modo, se identifica facilmente com os valores difundidos pelo mercado através da publicidade e da mídia em geral. O “consumidor-tipo” (Gorz, 2005) é aquele que procura e encontra, no consumo, um meio de se posicionar no mundo, de existir, de escapar da condição de sujeito comum para um feliz privilegiado. Sujeito ou consumidor "consumido" é aquele "cuja razão de existir se resume a comprar, comprar e comprar" (Baitello, 2012, p. 126, citando o sociólogo chileno Tomás Moulian e sua obra El consumo me consume; ainda sobre esse tema ver Vilém Flusser - A consumidora consumida). Na cultura patológica do consumo,

O comportamento do consumidor fica completamente inadaptado às tendências civilizadoras [...] De uma vez só, o consumidor imediatamente tanto absorve o mundo de produto, bens e coisas impostos a ele, e portanto o conquista, quanto é definido - via marcas, nomes de produtos e identidade do consumidor - por esse mundo. Ele tenta tornar o mercado seu, mesmo que este lhe faça prisioneiro [...] Ele anuncia um falso poder de consumo mesmo quando renuncia ao seu verdadeiro poder de cidadão (Barber, 2009, p. 46-47).

Já o "homem médio ideal” (Morin, 2005) abarca as características das formas anteriores e mais uma: o sincretismo, palavra mais apta para traduzir a tendência da mídia a homogeneizar sob um denominador comum a diversidade dos conteúdos. Um exemplo de homogeneização midiática é o formato do corpo difundido pela mídia: um corpo perfeitamente magro (como 
veremos no decorrer deste trabalho), que não pode ceder ou ter seu formato alterado mesmo quando sofre a ação de um processo natural como a gravidez. São formas-sujeito que, segundo Payer (2005), são atravessadas e constituídas em sujeitos pelo discurso midiático. Já o “modo consumista" (Bauman, 2005, p. 70) é aquele "que requer que a satisfação dos indivíduos seja, de qualquer forma instantânea, enquanto o valor exclusivo, enquanto a única 'utilidade' dos objetos é a sua capacidade de proporcionar satisfação". É um sujeito que habita a "sociedade de consumidores", um tipo de sociedade que atua sobre os sujeitos dirigindo-se a eles basicamente na condição de consumidores:

Ao fazê-lo, a "sociedade" (ou quaisquer agências humanas dotadas de instrumentos de coerção e meios de persuasão ocultos por trás desse conceito ou imagem) espera ser ouvida, entendida e obedecida. Ela avalia recompensa e penaliza - seus membros segundo a prontidão e adequação da resposta deles à interpelação [...] A "sociedade de consumidores", em outras palavras, representa o tipo de sociedade que promove, encoraja ou reforça a escolha de um estilo de vida e uma estratégia existencial consumistas, e rejeita todas as opções culturais alternativas. Uma sociedade em que se adaptar aos preceitos da cultura de consumo e segui-los estritamente é, para todos os fins e propósitos práticos, a única escolha aprovada de maneira incondicional. Uma escolha viável e, portanto, plausível - e uma condição de afiliação (Bauman, 2008, p. 71).

A forma sujeito-capitalista tem como perfil o individualismo, uma preocupação exacerbada consigo próprio, com seu corpo e com o sucesso profissional e econômico, um sujeito mais voltado para si, pouco empático, indiferente ao outro e com um excesso de atenção ao bem-estar (Peres, 2011). Dessa forma, nossa motivação é indagar, entre outras questões, qual a relação entre o sujeito-capitalista e o discurso contemporâneo das dietas? Segundo Orlandi (2012a), os sujeitos textualizam seu corpo pela maneira como estão nele significados, deslocando-se na sociedade e na história como corpos segregados, legítimos, tatuados, integrados ou fora de lugar, fazendo emergir uma questão central: qual é a relação do corpo com a ideologia? Recapitulando - em nossa pesquisa, a principal questão é: qual a relação do corpo feminino, portanto, da mulher enquanto forma histórica sujeito-capitalista, com a ideologia do universo midiático das dietas e suas supostas novidades? Quais os sentidos e os efeitos do novo e da novidade? Quais as ideologias e as práticas discursivas que se impõem sobre a constituição biológica desses mesmos sujeitos?

$\mathrm{Na}$ pesquisa que ora trabalhamos, pretendemos compreender o sujeito que, segundo Bauman (2010), “surfa nas ondas" das dietas das dietas e suas novidades. Vejamos um exemplo: 
uma leitora teve o seguinte comentário publicado em uma das edições da revista Corpo a Corpo:

\begin{abstract}
Recorte 1:
Dieta personalizada

Fiz o teste da matéria "Qual é a sua dieta?" (ed. 316) e fiquei surpresa com o resultado, afinal, ele reflete exatamente como é o meu estilo de vida hoje, que mudou muito de dois anos pra cá. E eu continuava comendo da mesma forma de antigamente e não conseguia emagrecer. Adorei a sugestão para o meu cardápio e já diminuí um número no manequim ${ }^{5}$ (grifos nossos).
\end{abstract}

O sujeito-leitor acima coloca-se na posição de crédulo diante do discurso das dietas. Mais do que isso: ele se apropria do discurso midiático das dietas para promover alterações em seu próprio corpo. Conforme salienta Milanez (2009), o sujeito reelabora a relação que tem consigo próprio "ao se apoderar de outros corpos que, à primeira vista, são outros, mas que, no final, são nada menos que o próprio sujeito" (p. 282). Suspeitamos que surfar nas ondas das dietas e dos produtos para emagrecimento, "diminuir um número no manequim" como fez a leitora acima, mostra a identificação do sujeito contemporâneo com a ideologia da magreza e do corpo-perfeito. Esta identificação inscreve discursivamente, assim, um efeito de busca de si para cada sujeito, seu processo de constituição na contemporaneidade, obrigando-se a ser magro, a testar dietas e a emagrecer. Pretendemos, aqui, da mesma forma que Milanez o faz em uma de suas pesquisas, arriscar um percurso sobre a constituição do sujeito através "da subjetivação como ato de possuir um outro corpo para dar forma ao seu próprio corpo" (Milanez, 2009, p. 282). O ato de subjetivar-se ocorre quando "a ideologia interpela o indivíduo em sujeito e este submete-se à língua significando-se pelo simbólico na história [...] Em outras palavras, para dizer, o sujeito submete-se à língua. Sem isso, não tem como subjetivar-se" (Orlandi, 2005, p. 100). O discurso do corpo saudável, diz Gregolin, que pressupõe o discurso das dietas e boa forma, "atravessa diferentes campos da inteligibilidade social, materializa-se em diferentes gêneros e objetiva distintas representações sobre como deve-se subjetivar a relação dos indivíduos com seu próprio corpo-saúde" (2007, p. 19). Em relação ao discurso das dietas, veremos vários exemplos da influência midiática no processo de subjetivação do sujeito contemporâneo.

\footnotetext{
${ }^{5}$ Comentário dos leitores publicados na Revista Corpo a Corpo (ed. 317).
} 


\section{Capítulo 2}

\section{LIPOFOBIA, FORMAÇÃO DISCURSIVA DAS DIETAS, IMAGEM E IDEALIZAÇÃO CORPORAL}

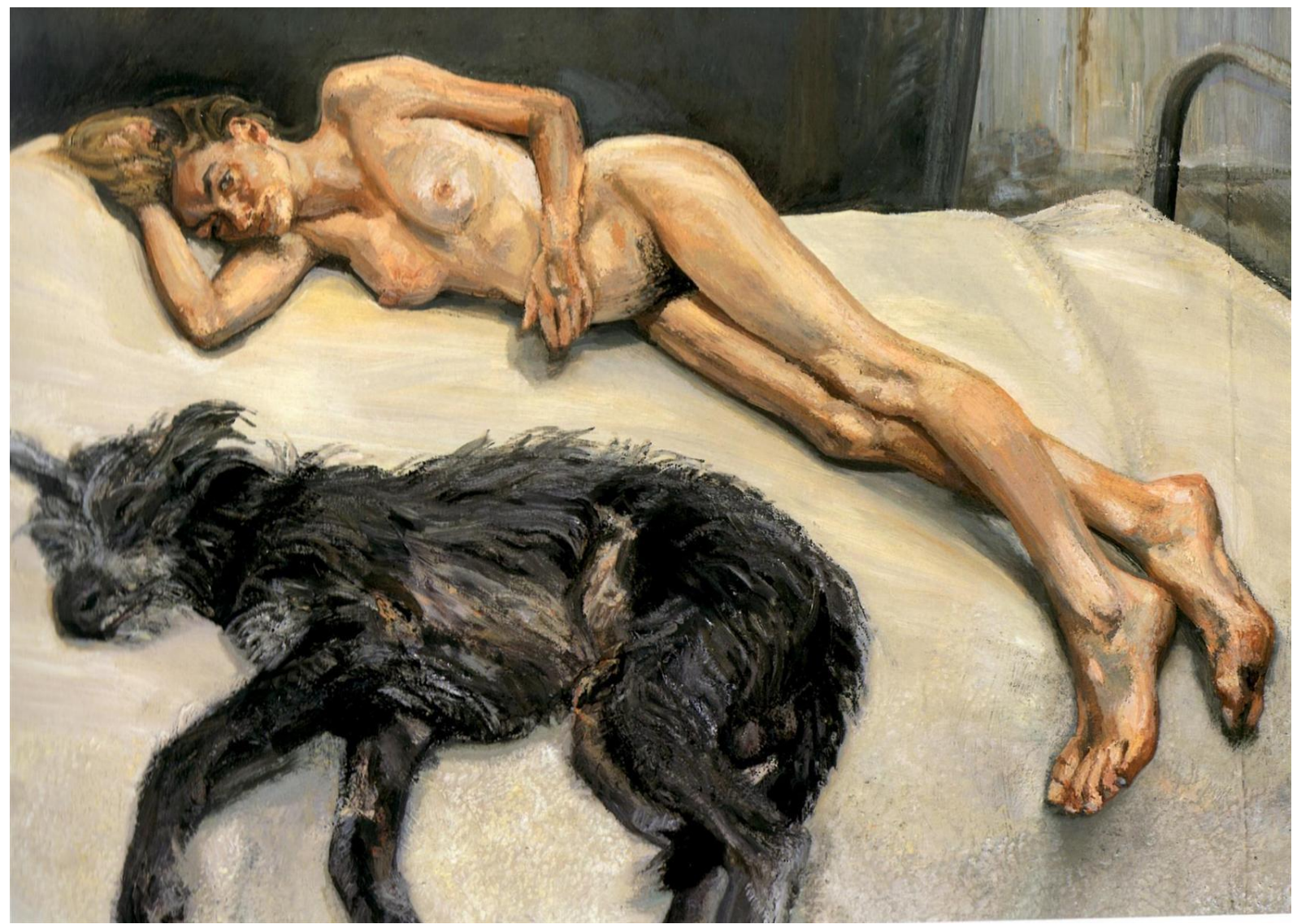

Annabel and Rattler (Lucian Freud, 1998)

Não possuímos nem o corpo, nem uma verdade - nem sequer uma ilusão. Somos fantasmas de mentiras, sombras de ilusões, e a nossa vida é oca por fora e por dentro. Conhece alguém as fronteiras à sua alma, para que possa dizer - eu sou eu? Mas sei que o que eu sinto, sinto-o eu.

Fernando Pessoa 


\subsection{Lipofobia: efeitos midiáticos da perda de peso}

A preocupação das sociedades contemporâneas em perder peso aumentou consideravelmente no último século e, segundo alguns profissionais da saúde, tornou-se um problema de graves proporções. A afirmação é da historiadora da medicina Louise Foxcroft, responsável por uma robusta pesquisa histórica sobre as dietas - A tirania das dietas: dois mil anos de luta contra o peso (2013). A história avassaladora das dietas começou nos tempos praticamente sem registros da pré-história, ganhando importância há aproximadamente 2 mil anos, quando os gregos desenvolveram uma maneira de enfrentá-la. Segundo a historiadora, teria sido o filósofo e médico grego Hipócrates (460-370 a.C.) um dos primeiros a pregar que os princípios subjacentes da saúde eram o alimento e o exercício. Todo o fundamento da ciência médica ocidental valia-se da diatetica - a terapia curativa fundamental de um regime com determinados alimentos. Portanto, ser muito gordo ou muito magro era um sinal de um corpo não saudável. A diatetica teria sido o fundamento antigo da ciência médica ocidental, uma terapia curativa essencial de um regime de condutas que prescrevia alimentos e maneiras específicas de comer (Foxcroft, 2013). Nesse contexto, a diatetica incluía a perda de peso somente quando necessária, e não por razões puramente estéticas.

O que torna, então, a era em que vivemos diferente de outros períodos históricos em relação ao corpo? A historiadora Mary Del Priori, no prefácio do livro Do altar às passarelas: da anorexia santa à anorexia nervosa (Weinberg e Cordás, 2006), dá uma pista para responder a essa pergunta - as sociedades modernas, afirma, são lipofóbicas: odeiam a gordura e os corpos gordos. Diz Del Priori (2006):

\footnotetext{
Por um lado, a cultura de massas, produtora de milhares de imagens, estimulanos a admirar e invejar corpos jovens e esbeltos. Por outro lado, a medicina vê na obesidade um problema de saúde pública, procurando, em resposta, impor suas próprias normas quantitativas para um "peso teórico ideal". Os corpos verdadeiros, os reais, correm, por sua vez, desesperados atrás dos modelos sonhados. Ou prescritos (p. 11).
}

Na mesma linha de raciocínio, Foxcroft (2013) alerta que temos uma aversão comum à gordura, algo como uma "repulsa estética", que não deve ser confundida com preocupações com a obesidade e a saúde. A preocupação em perder peso não se restringe ao mundo da moda ou a um nicho da sociedade. O psiquiatra Táki Athanássios Cordás e a psicanalista Cybelle Weinberg relatam que o aumento da incidência da anorexia nervosa nas últimas décadas teria 
como explicação as pressões sociais cada vez maiores para que as mulheres tenham um corpo magro, especialmente quando atuam em meninas jovens, numa idade em que elas são mais vulneráveis - ou quando as mesmas têm ocupações em áreas em que a forma e o tamanho do corpo são enfatizados (Weinberg e Cordás, 2006). O ato de fazer dieta não é algo recente. Segundo Foxcroft (2013), a palavra grega díaita, da qual deriva nossa palavra dieta, descrevia todo um modo de vida, fornecendo um caminho completo, mental e físico, para a saúde, a própria existência e o sucesso. No dicionário Michaelis ${ }^{6}$, a palavra dieta é um substantivo feminino que pode significar:

- regime alimentício prescrito a um doente ou convalescente;

- privação de todos ou de alguns alimentos, em caso de doença;

- emprego metódico das coisas úteis para a conservação da saúde;

- predominância de um alimento na nutrição: Dieta láctea;

- cetogênica: dieta que fornece grande quantidade de gordura e quantidades mínimas de carboidratos; usada especialmente na epilepsia, para produzir cetose e alterar o grau de alcalinidade corporal.

Na esteira da lipofobia e diferentemente do que consta no dicionário, a palavra "dieta", em sua versão midiática, assume outros efeitos de sentido que estão além da preocupação com a saúde e bem-estar ou a prescrição de determinados alimentos. O sentido de uma palavra, argumenta Pêcheux (2009), de uma expressão, de uma proposição - e no nosso caso, de uma matéria jornalística, de uma imagem midiática, entre outras possibilidades de disseminação de informação - não existe em 'si mesmo', em sua relação transparente com a literalidade do significante. "Mas, ao contrário, é determinado pelas posições ideológicas que estão em jogo no processo sócio-histórico no qual as palavras, expressões e proposições são produzidas, isto é, reproduzidas" (Pêcheux, 2009, p. 146). Nos recortes abaixo sobre dietas que circulam em nosso corpus de análise, é possível que as palavras e expressões "mudam de sentido segundo as posições sustentadas por aqueles que as empregam" (Pêcheux, 2009, p. 146-147).

\section{Recorte $2^{7}$ :}

\footnotetext{
${ }^{6}$ Recuperado em 5 de julho de 2016, de http://michaelis.uol.com.br/busca?r=0\&f=0\&t=0\&palavra=dieta

${ }^{7}$ Tentaremos reproduzir o texto dos recortes o mais fiel possível em relação ao original. Como as revistas e sites usam diferentes recursos de diagramação, nem sempre essa reprodução será exatamente igual. Para os comentários dos leitores/internautas, também procuraremos manter a reprodução mais próxima do texto original. Para facilitar a leitura deste trabalho, optamos pela seguinte distribuição das referências: todos os recortes extraídos do nosso corpus, detalhado no item "Método e metodologia", terão sua indicação bibliográfica disposta em notas de rodapé. As demais obras consultadas constarão nas referências.
} 
Dieta da proteína: enxuga 7 quilos em 14 dias $^{8}$

Dieta Dukan elimina $5 \mathrm{~kg}$ em 15 dias $^{9}$

Dieta Nórdica: nova forma saudável de perder peso ${ }^{10}$

Dieta Viking: - $2 \mathrm{~kg}$ por semana! ${ }^{11}$

Dieta do GH: - 4 kg em 1 mês com cardápio que estimula o hormônio do crescimento $^{12}$

Dieta flex: - 4 kg em 30 dias. É só reduzir a carne do cardápio ${ }^{13}$

- $3 \mathrm{~kg}$ por semana! com a dieta da sopa detox ${ }^{14}$

Barriga chapada com a dieta das castanhas. Elas acabam com a fome e reduzem a vontade por doces. Veja como usar na sua receita ${ }^{15}$

- $5 \mathrm{~kg}$ em 21 dias com direito a pé na jaca ${ }^{16}$

As sequências discursivas acima indiciam que, ao serem empregadas/sustentadas pelo/no discurso midiático, as palavras de ordem “enxuga, elimina, reduzem”, atreladas à Formação Discursiva contemporânea sobre dieta, promovem um deslizamento para outros efeitos de sentidos que provavelmente são diferentes dos sentidos que os gregos atribuíam à dieta. A Formação Discursiva (FD) pode ser compreendida como o que, em um dado contexto sócio-histórico, define o que pode e deve ser dito, já que o sentido é afetado por meio da inscrição do discurso em uma determinada FD e não em outra(s), o que interfere na forma como o(s) sentido(s) são produzido(s) (Bastos, Garcia e Sousa, 2014). Uma FD não é atemporal, diz Indursky (1997), mas determina uma regularidade própria a processos temporais, construindo um esquema de correspondência entre diferentes séries temporais. Dependendo da Formação Discursiva na qual o enunciado está inscrito, teremos outras produções de sentidos, por isso o sentido sempre pode ser outro, mas nunca qualquer sentido (Bastos, Garcia e Sousa, 2014).

$\mathrm{Na}$ FD do universo das dietas, os sentidos que circulam na mídia estão relacionados estritamente à perda de peso subjacente aos padrões corporais atuais, o que se marca pelo uso numérico de quilos a serem perdidos em um determinado número de dias. A perda de peso deve ser rápida, eficaz e definitiva, o que marca um modo de inscrição do tempo na

\footnotetext{
8 Recuperado em 8 de janeiro de 2016, de http://mdemulher.abril.com.br/dieta/boaforma/anovadietadaproteinaenxuga7quilosem14dias

${ }^{9}$ Recuperado em 8 de janeiro de 2016, de http://mdemulher.abril.com.br/dieta/boaforma/anovadietadukanelimina5kgem 15 dias

10 Recuperado em 8 de janeiro de 2016, de http://mdemulher.abril.com.br/dieta/claudia/dietanordicanovaformasaudaveldeperderpeso

11 Os títulos para as matérias que são destaques de uma determinada edição impressa são denominados "chamadas de capa". O texto em questão é chamada de capa da revista Shape (edição n. 68).

${ }^{12}$ Chamada de capa da revista Boa Forma (edição n. 343).

${ }^{13}$ Chamada de capa da revista Boa Forma (edição n. 345).

${ }^{14}$ Chamada de capa da revista Shape (edição n. 69).

${ }^{15}$ Chama de capa da revista Dietas Já (edição n. 247).

${ }^{16}$ Chamada de capa da revista Shape (edição n. 67).
} 
contemporaneidade, qual seja, o tempo acelerado e com consequências próximas. A ideia em voga é subtrair: enxugar, eliminar, queimar ou perder peso; diminuir, saciar ou acabar com a fome; diminuir o número do manequim ou as medidas corporais. Nas marcas linguísticas materializadas no dicionário para a palavra "dieta" 17 , não constam perda de peso ou diminuição da massa corporal. Em comum, tais sequências reiteram que os efeitos de sentidos das dietas têm como objetivo fazer desaparecer ou definhar os contornos corporais até o "tamanho zero", expressão usada pela modelo Kate Moss que demonstra o culto ao estilo que tomou conta do universo das passarelas e da mídia nos últimos anos.

Um dos aspectos contraditórios que podemos observar em uma das chamadas acima é a sugestão de que é possível perder peso rapidamente (- $5 \mathrm{~kg}$ em 21 dias) ingerindo todo tipo de alimento e em qualquer quantidade (com direito a pé na jaca). Nas práxis do universo midiático das dietas, os sentidos transmitem a ilusão de que é possível emagrecer de forma fácil e rápida (como também veremos mais adiante). A expressão "pé na jaca" do recorte acima evoca efeitos que remetem ao exagero, dando uma espécie de "permissão" ao sujeito para que cometa abusos ou excessos alimentares, o que entra em choque com a possibilidade de emagrecer de forma rápida.

As contradições não param nas chamadas de capa. O interior do texto mostra a rotina de uma atriz para manter a forma. Em um dos trechos há o subtítulo "Menu Light", seguido da seguinte narrativa: "Filha de pai gaúcho e mãe pernambucana, Paloma revela que na sua casa é uma mistura de tapioca, churrasco, rabada, queijo coalho, e ela come de tudo" ${ }^{18}$. É como se o sujeito pudesse emagrecer ingerindo em algum momento alimentos de alto valor calórico e em grandes quantidades, o que vai na contramão das restrições impostas pelas dietas que circulam no ambiente midiático.

\subsection{Em busca da dieta perfeita (e do corpo-perfeito)}

\footnotetext{
Мeu corpo пão é meu corpo, é ilusão de outro ser. Sabe a arte de esconder-me e é de tal modo sagaz que a mim de mim ele oculta. Carlos Drummond de Andrade
}

\footnotetext{
${ }^{17}$ No capítulo 3, faremos uma análise e reflexão sobre os nomes das dietas e seus efeitos de sentidos.

${ }^{18}$ Matéria da revista Shape (edição n. 67, p. 12).
} 
Uma das teorias da mídia (que tenho pesquisado desde o mestrado) entende o corpo como "início e fim de toda comunicação" 19 . Em outras palavras, ela só ocorre se um corpo vivo consegue vincular-se a outro corpo vivo. Uma mensagem rupestre de uma caverna que nunca foi vista por ninguém, um livro que não é lido, uma carta que nunca foi aberta, uma mensagem de e-mail que não chega ao seu destinatário: onde não há corpo não há comunicação. A comunicação a que nos referimos é fora das categorias reducionistas de "produto" e de "código" ou, mais correntemente, de "linguagem", mas processo de construção de vínculos e ambientes de vínculos. Trata-se de algo muito mais abrangente composto pela história, cultura, imagens exógenas e endógenas (aqui estaria o inconsciente), também sujeito a falhas, equívocos, sombras, a aquilo que não foi dito ou revelado.

Durante minha pesquisa sobre os corpos que atuam como suportes midiáticos (Sanches, 2009), tendo como base outra perspectiva teórica que também entende o homem como um ser simbólico $^{20}$, assim como Orlandi (2012a) também o faz ao conceber os homens como seres simbólicos e histórico-sociais, havia relatado o corpo-mídia ou corpo-anúncio: corpos reconfigurados pela publicidade como uma realidade idílica, como um suporte sígnico para o que se pretende anunciar. Ao fazer uso do corpo como suporte sígnico para sua própria linguagem, a publicidade idealiza um corpo ideal (para o que se pretende anunciar/divulgar). Ao revisitar aquelas ideias para a concepção da atual pesquisa, entendo que já estava na base primordial daquelas reflexões a interpelação dos corpos pela ideologia (em especial às produzidas pela mídia e seus discursos). Não exatamente com esse gesto de leitura, mas durante aquele percurso investigativo a ideologia e a interpelação já estavam subjacentes aos objetos pesquisados. Quando havia dito, por exemplo, que um determinado corpo havia sido reconfigurado pela publicidade em um ideal de beleza, posso agora afirmar, ao trabalhar com a

\footnotetext{
${ }^{19}$ O clássico pensamento de que toda comunicação começa e termina no corpo foi formulado pelo cientista político, escritor, jornalista e comunicólogo alemão Harry Pross (Baitello, 2005).

${ }^{20}$ Minha pesquisa de Mestrado teve como referencial teórico a Semiótica da Cultura. Em poucas palavras, não se trata de uma ciência da estética ou uma história da arte, mas uma ciência que "pretende investigar como os processos culturais, como o cerne germinador da cultura - que é em essência artístico - opera em todas as épocas culturais" (Bystrina, 1995, p. 22). A cultura é entendida como o conjunto sincrônico dos textos imaginativos e criativos, o conjunto de textos produzidos pelo homem. Deve-se assim entender por "textos da cultura" não apenas aquelas construções da linguagem verbal, mas também imagens, mitos, rituais, jogos, gestos, cantos, rito, performances, danças etc. Segundo Baitello (1997), a cultura é um "conjunto de artifícios simbólicos, melhor ainda, um sistema simbólico que abriga o homem e sua complexa natureza, após seu nascimento, a um tempo moldado e moldador de uma rede interativa de grupos sociais em escala diversa, desde a familiar até a escala planetária. Esse sistema simbólico - como todos os sistemas de símbolos - está sujeito às transformações solicitadas pelas necessidades de seu criador e usuário [...] Assim, a cultura, como sistema comunicativo, tem como principal função a de ordenar as informações de uma sociedade [...] A cultura tem a função de "criar, transmitir e manter o presente no passado e no futuro, e criar, transmitir e manter o futuro no presente e no passado" (Baitello, 1997).
} 
Análise do Discurso, que aqueles corpos haviam sido interpelados pela ideologia do corposuporte proveniente dos discursos midiáticos e publicitários. Retomamos aqui o conceito de sujeito que abordamos no capítulo anterior. O sujeito, diz Pêcheux (2009, p. 148), é produzido com aquilo que lhe é dado ver, compreender, fazer, temer, esperar etc., reconhecendo a si mesmo (em si mesmo e em outros sujeitos) - posto que afetado pelos dois esquecimentos - mas também se reconhecendo, se identificando e desejando o corpo perfeito das revistas e sites de boa forma. Quem explica os conceitos de "esquecimento número um" e "esquecimento número dois" formulados por Pêcheux em Semântica e Discurso é Orlandi (2009): o número dois é da ordem da enunciação - ao falarmos, o fazemos de uma maneira e não de outra, o que produz em nós a impressão de realidade do pensamento, o que nos faz acreditar que há uma relação direta entre pensamento, linguagem e mundo, estabelecendo uma relação natural entre palavra e coisa. $\mathrm{O}$ esquecimento número um, também chamado de esquecimento ideológico, é da instância do inconsciente e resulta do modo pelo qual somos afetados pela ideologia; assim, temos a ilusão de ser a origem do que dizemos quando, na realidade, retomamos sentidos preexistentes; quando nascemos, os discursos já estão em processo é nós é que entramos nesse processo.

Esse é um dos aspectos que, nas duas pesquisas, permitem observar, em práticas e condutas corporais, o entrelaçamento entre sujeito e ideologia, pois ambas partem também do enlace entre imagem (discurso), corpo (sujeito) e mídia. Nesse mecanismo imaginário (portanto simbólico) o sujeito se imagina uno, fonte do dizer e senhor de sua língua. Dessa forma, apagase para o sujeito o fato de ele entrar nessas práticas histórico-discursivas já existentes (como a ideologia do corpo-perfeito presente nos discursos publicitários e midiáticos das dietas). É a ideologia, afirma Romão (2009), que tece a trama de que certos dizeres estão autorizados a serem tomados como próprios pelo/do sujeito em determinadas condições sócio-históricas, a partir do lugar de onde ele fala e das regiões de poder implicadas nesse falar. Orlandi (2012a) pontua que a ideologia não aparece como ocultação, nem tem um sentido negativo; também não se trata de uma falsa consciência ou uma pura alteridade, mas o modo através do qual os homens vivem suas relações em relação às suas condições de existência.

Durante o Mestrado, pude observar claramente que, na contemporaneidade, são vários os modelos de corpos impostos pela sociedade imagética. Não é possível abordá-los todos em um único trabalho, porque são inesgotáveis, nascem e morrem (re)criando tendências e padrões de beleza, estética e consumo. Um deles é o “corpo-cabide” (Campelo, 2003, p. 42), destinado a portar/desfilar roupas, grifes e acessórios em passarelas de todo o mundo. 
O que acontece, então, quando o sujeito contemporâneo, ao ser entrelaçado pela ideologia, depara-se, em seu processo de subjetivação, com os enunciados e as imagens midiáticas das dietas? Os blogs e revistas sobre "boa forma" e "vida saudável" trazem periodicamente um novo manual para emagrecer, muitas vezes endossado por celebridades de corpos esbeltos. Os tratamentos para perder quilos de forma rápida são diversos e mudam rapidamente, mas expõem características em comum: são lançados como a "última novidade", a mais "nova fórmula", imbuída da "mais recente descoberta". Podem ser novos exercícios, novos remédios, bebidas, alimentos ou novas maneiras de se alimentar (ou a combinação de vários métodos) ${ }^{21}$. "O desejo de alterar suas proporções corpóreas muitas vezes leva as pessoas a manipulações dietéticas" (Laus et al., 2013, p. 106).

Ao relacionar sujeito/corpo/linguagem/sociedade, Orlandi (2012a) atesta que podemos compreender como o corpo, pensando a materialidade do sujeito, sua historicidade, é significado em um ou outro espaço de existência, como o ambiente midiático das dietas e seus discursos. O sujeito é bombardeado por vários e conflitantes discursos, que muitas vezes se encontram em rota de colisão. Se por um lado ele é instigado a experimentar todo tipo de comida, com empresas de fast food oferecendo promoções do tipo "2 em 1" ou "coma isso mais aquilo", por outro o sujeito é conclamado a ser magro a qualquer custo. É justamente essa ordem de contradição que nos interessa analisar nos dados que se seguem.

\subsection{A imagem arde: dietas, corpo, memória, ideologia e discurso}

Nunca conheci quem tivesse levado porrada. Todos os meus conhecidos têm sido campeões em tudo.

Quem me dera ouvir de alguém a voz humana Que confessasse não um pecado, mas uma infâmia; Que contasse, não uma violência, mas uma cobardia! Não, são todos o Ideal, se os oiço e me falam.

Arre, estou farto de semideuses! Onde é que há gente no mundo?

Fernando Pessoa

\footnotetext{
${ }^{21}$ A questão do novo e da novidade é uma formação discursiva que perpassa diversas etapas deste trabalho. Uma reflexão mais aprofundada será mostrada no Capítulo 4 "O novo e a novidade".
} 
Uma das questões que norteiam nosso percurso investigativo é: qual a memória que o sujeito contemporâneo tem sobre o corpo e dietas? O cerne do nosso questionamento, direcionado ao corpo, dietas e mídia, teve como base a seguinte indagação, formulada por Payer (2005, p. 11): “Qual é o lugar da memória pessoal, cultural e social, em face da proliferação cotidiana de linguagens na mídia?" Primeiramente, memória aqui não deve ser entendida no sentido psicológico, da "memória individual", mas ao que Pêcheux (2010) denominou "memória social inscrita em práticas", que podem ser culturais, sociais, cotidianas, midiáticas. A memória - argumenta Pêcheux (2010) - tem o papel de estruturar a materialidade discursiva complexa, entendida em uma dialética da repetição e da regularização. "A memória discursiva seria aquilo que, face a um texto que surge como acontecimento a ler, vem restabelecer os 'implícitos' (quer dizer, mais tecnicamente, os pré-construídos, elementos citados e relatados, discursos-transversos, etc.)" (Pêcheux, 2010, p. 52). A memória faz parte da produção do discurso, o que em AD é denominado interdiscurso: aquilo que fala antes, em outro lugar, independentemente, mobilizando dizeres que afetam o modo como o sujeito significa em uma situação discursiva dada (Orlandi, 2009). O interdiscurso é o "saber discursivo, a memória do dizer, e sobre o qual não temos controle. Trata-se do que foi e é dito a respeito de um assunto qualquer", pondera Orlandi (2005, p. 180). Tanto a memória quanto o saber discursivo compõem a constituição do discurso, sua dimensão vertical (Orlandi, 2005). No nosso caso, o assunto envolve o universo midiático das dietas e boa forma e suas supostas novidades. No entanto, ao longo do tempo e do uso acabamos por esquecer o que foi dito (é praticamente impossível acompanhar o ritmo com que surgem novas dietas, como veremos mais adiante), esquecemos quem disse (é imensa a quantidade de notícias sobre o assunto, principalmente no mundo virtual), e em que circunstâncias; assim, o que foi dito por alguém em determinadas circunstâncias segue como um já-dito sobre o qual os sentidos sobre as dietas se constituem.

Uma vez que a interpelação ideológica do indivíduo inaugura a discursividade, "o trabalho ideológico é um trabalho da memória" (Orlandi, 2009, p. 49). Desse modo, não há sujeito sem ideologia e sem memória, assim como não há forma-sujeito sem ideologia e sem memória. A ideologia promove o efeito de evidência para que o sujeito diga de um modo (o corpo contemporâneo deve ser magro) e não de outro, diz Romão (2009), supondo serem suas as palavras, atrevendo-se à ilusão de que elas expressam seu pensamento com nitidez e exatidão. A ideologia é a grande artífice do mecanismo que permite ao sujeito enunciar e acreditar que sua palavra é idêntica à representação que faz do mundo, apagando possíveis modos de nomear e dizer (Romão, 2009). Assim, podemos inferir que:

- uma vez que não há sujeito sem ideologia e sem memória, 
- também não há forma-sujeito e posição-sujeito sem ideologia e sem memória,

- logo, não há corpo sem ideologia e sem memória.

Para tentar responder à questão: qual a memória que o sujeito contemporâneo tem sobre “corpo" e "dietas", discutiremos, em um primeiro plano teórico, a relação entre memória e imagem proposta por Orlandi (2012a). Em um segundo momento, mostraremos algumas imagens de corpos ao longo da história e na atualidade que podem dar pistas não para uma resposta única, mas para trilhar um caminho, elucidando alguns pontos que nos ajudarão a refletir sobre a relação sujeito/mídia/dietas na atualidade.

Enquanto materialidade significante, as imagens midiáticas (em especial àquelas que circulam em nosso corpus) são fundamentais para compreender o processo discursivo sobre o qual se insere nosso objeto de pesquisa (novas dietas), como veremos no capítulo 5 (A iconografia das dietas). Pensando na relação entre corpo, imagem e memória, partimos da reflexão postulada por Benedetti e Romão (2007, s/p): sendo o corpo um organismo mediador de saberes e resultado de uma construção sociocultural e histórica, podemos, neste trabalho de pesquisa, "mobilizar o conceito de memória discursiva, pois entendemos que tais discursos sobre o corpo possuem um domínio de memórias pré-construído e materializado por sua repetibilidade (ou não)”. Para estabelecer um vínculo entre imagem e memória, Orlandi (2012a) mobiliza duas reflexões, uma elaborada por Pêcheux e outra por Davallon na obra "Papel da Memória" (2010). Às reflexões sugeridas pela autora acrescentamos mais três. A primeira, de Georges Didi-Huberman, aponta que uma imagem não é um simples corte praticado no mundo dos aspectos visíveis, mas "uma impressão, um rastro, um traço visual do tempo que quis tocar, mas também de outros tempos suplementares - fatalmente anacrônicos entre eles, que não pode, como arte da memória, não pode aglutinar [...] Nisto, pois, a imagem arde" (Didi-Huberman, p. 11). A segunda é proposta por Norval Baitello Jr. (2005), ao considerar a irresistível pressão das imagens sobre os corpos verdadeiros, sujeitos ao tempo e ao envelhecimento. A terceira, postulada por Gregolin (2007, pp. 18-19), sustenta que a sofisticação técnica, como as que empregadas na construção do corpo-projeto, "produz uma verdadeira saturação identitária pela circulação incessante de imagens que têm o objetivo de generalizar os modelos. A profusão dessas imagens age como um dispositivo de etiquetagem e de disciplinamento do corpo social". O resultado dessa discussão, afirma Orlandi (2012a), deixando as divergências de lado, aponta para algumas leituras discursivas possíveis, nas quais destacamos os seguintes aspectos que levam em conta os conceitos e reflexões sobre as imagens que aqui mobilizamos:

- a imagem (nos) interessa pela sua eficácia simbólica; 
- como qualquer materialidade significante, também a imagem não é transparente, é materialidade; portanto, tem seu modo de funcionamento passível de interpretação;

- a imagem possui uma história, uma arqueologia; assim, Orlandi argumenta que Davallon aproxima a imagem do que diz Pêcheux sobre a memória como interdiscurso (algo fala antes, em outro lugar e independentemente);

- nessa linha de raciocínio desenvolvida por Orlandi, uma vez que a Análise do Discurso entende a memória discursiva como exterioridade constitutiva, a razão de ser da imagem está fora do espaço da imagem (não se trata de reduzir uma coisa à outra, mas procurar estabelecer que esses funcionamentos permitem pensar a imagem a partir da perspectiva da memória discursiva);

- face à interpretação, não podemos nos ater apenas à imagem como algo legível e transparente, mas devemos investigá-la em sua complexidade, tentando compreender os vários discursos que a atravessam e a constituem;

- no nosso caso, a iconografia das dietas não deve ser compreendida apenas na transparência das imagens, mas no jogo discursivo no qual elas estão inseridas;

- as imagens de corpos presentes no discurso midiático das dietas e boa forma exercem uma pressão sobre os corpos reais, indicando modelos a serem seguidos, copiados, de formatos corporais articulados pela mídia, através de um movimento incessante de generalização dos modelos corporais;

- a imagem, quando toca o real, arde;

- a imagem é discurso.

Enquanto discurso, a imagem não deve ser tratada como “"coisa' concreta, mas como objeto da ordem do imaginário, da antinomia entre visível e invisível e suas implicações ideológicas" (Vargas, Medeiros, \& Beck, 2011, p. 48). Nesse sentido, a imagem, para a Análise do Discurso franco-brasileira, vai ao encontro do que já entendíamos como conceito/noção de imagem, ancorando nossa concepção teórica nas pesquisas de Hans Belting, mais especificamente em sua obra Pour Une Anthropologie des Images, Dietmar Kamper (2002) e Norval Baitello Jr. (2005; 2012). Em outro texto, Belting assinala que as imagens "não existem por si mesmas, mas, sim, acontecem; elas ocorrem, sejam elas imagens em movimento (o que se torna tão óbvio), ou não" (2006; s/p). Por trás da visibilidade de uma imagem emergem numerosas configurações que a acompanham e nossa visão não consegue identificar: as camadas históricas, o imaginário, a cultura (Sanches, 2009), ou seja, àquilo que é da ordem do simbólico. Portanto, a maioria delas é invisível e pode apenas ser percebida por seus vestígios ou pelos outros sentidos que não a visão (Sanches, 2009). A imagem assume, assim, a 
perspectiva de um "objeto simbólico-ideológico", que apresenta um "espectro do visível e do invisível" e atua como produtora "tecnoideológica de sentidos"; em consequência, "reclama sentidos" que não estão, necessariamente, "dados, contidos ou mesmo escondidos nela" (Vargas et al., 2011, p. 43).

Uma vez que os enunciados sobre um tema, como dietas ou corpo, “apesar de recorrentes e repetíveis, não pertencem sempre à mesma enunciação, já que suas condições de produção e existência transformam-se historicamente" (Benedetti e Romão, 2007, s/p); assim, lançamos um olhar para o passado na tentativa de elucidar o presente. Esse exercício retrospectivo tem como objetivo resgatar alguns formatos de corpos que circularam em diferentes épocas, cujas condições de existência eram historicamente diferentes. Não temos a pretensão de estabelecer um tratado arqueológico das dietas, tampouco do corpo e suas representações artísticas. Para não nos alongarmos demais nesse tópico, fizemos um salto histórico relativamente grande. Pretendemos, apenas, pinçar alguns exemplos de como os corpos foram representados em diferentes momentos históricos - como argumenta DidiHuberman (2012, p. 7); selecionamos pequenos "encontros de temporalidades contraditórias" que afetam determinados objetos ou acontecimentos; representações que contrastam de forma veemente com o corpo e sua imagem idealizada na atualidade pela mídia.

Vejamos. No século XVII, Peter Paul Rubens pintou Vênus ao Espelho (1614-1615). A Vênus ao Espelho ${ }^{22}$ representa a deusa romana do amor, da beleza e da fertilidade reclinada languidamente na sua cama, com as costas para o espectador.

\footnotetext{
${ }^{22}$ Recuperado em 1 de dezembro de 2014, de http://www.psicanaliseebarroco.pro.br/Imagens/rub3.jpg
} 


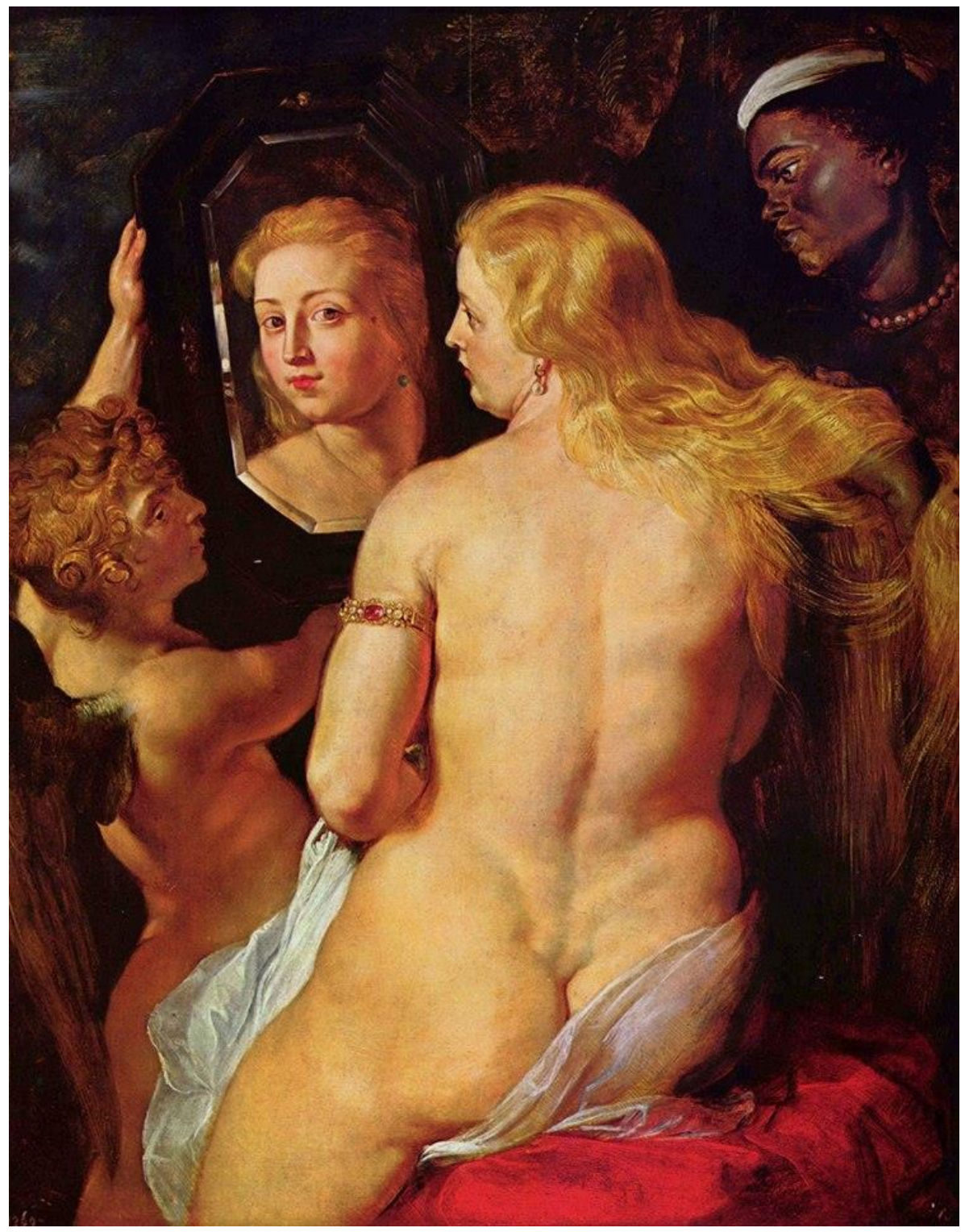

Figura 1. Vênus ao Espelho, de Paul Rubens

Provavelmente, a obra retrata um ideal de beleza, assim como também fora retratada por Diego Velázquez ainda no século XVII. A modelo, de costas, possui um corpo com curvas, dobras, algo natural e até envolvente para a época em que foi retratada. Mesmo que a Vênus de Rubens não representasse, necessariamente, um padrão de beleza de sua época, suas formas tiveram um espaço privilegiado no mundo das artes, sendo retratada por um notável artista da época. Foxcroft (2013) atribui à figura rechonchuda retratada por Rubens no período medieval à forma cobiçada da figura reprodutora - carnuda, cheia, fértil e redonda, percebida também nas pinturas de Rembrandt nos anos 1600 e Renoir nos anos 1800. 
Já no século XX, há pouco menos de cem anos, um ícone de beleza do cinema americano, Marilyn Monroe ${ }^{23}$ (Norma Jeane Mortenson), exibia curvas de um corpo mais volumoso em comparação aos corpos esguios de nossa época. Ainda era possível visualizar dobras, como as da barriga de Marilyn na foto abaixo:

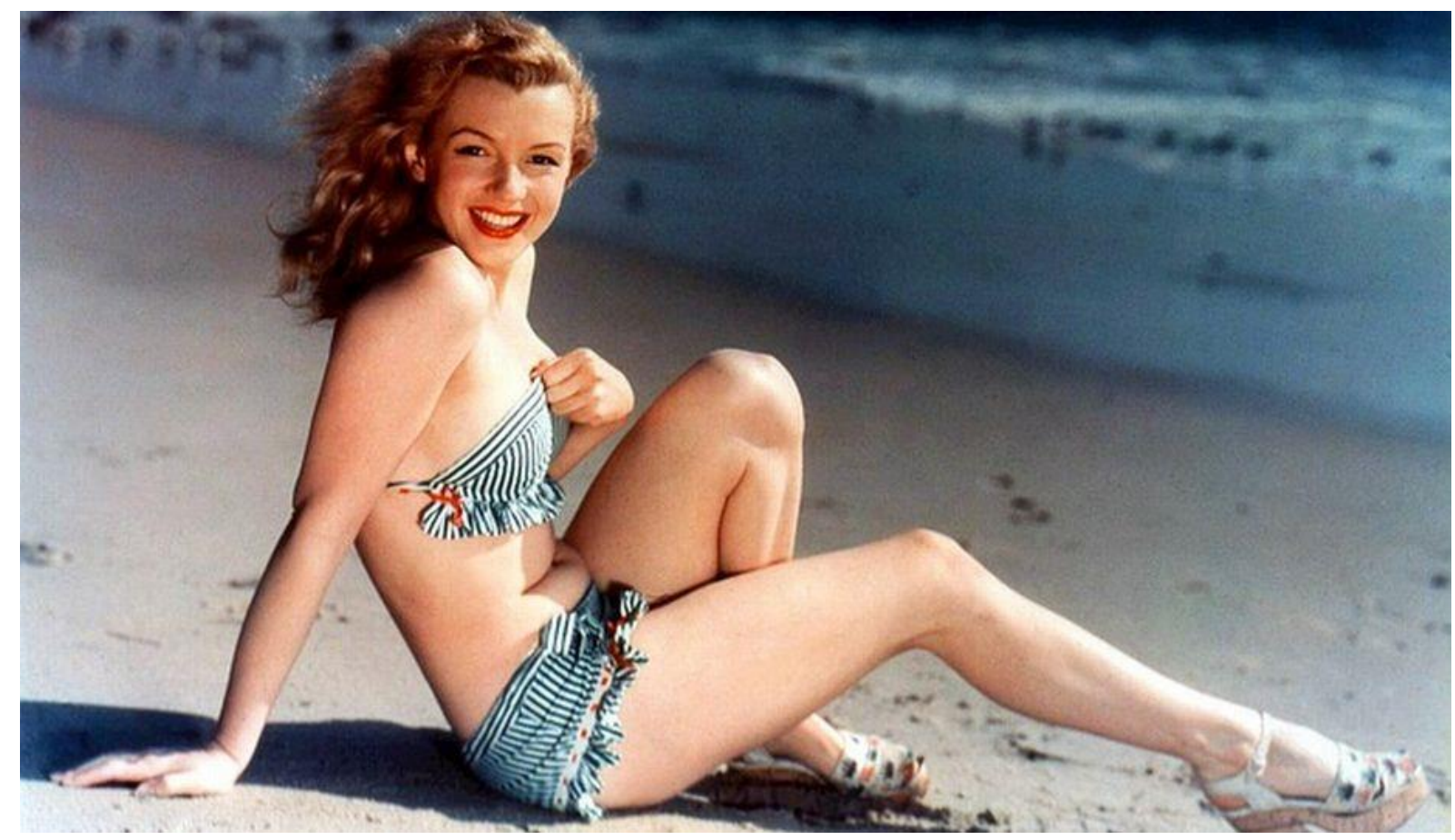

Figura 2. Marilyn Monroe exibe suas curvas em uma praia ${ }^{24}$

Dando um salto no tempo e pousando no século XXI, um evento de grande proporção midiática chamou atenção para um formato de corpo específico que, para espanto de uma parcela considerável dos jornalistas e comentaristas, não poderia estar ali. Em 29 de janeiro de 2017, o concurso Miss Universo causou alvoroço quando a representante do Canadá, Siera Bearchell, foi taxada de "maior que as outras". No Brasil, um dos comentaristas do canal responsável pela transmissão do evento disse que a participação da canadense era para "cumprir cota" (Resende, 2017).

\footnotetext{
${ }^{23}$ Aliás, o corpo da Marilyn Monroe enquanto imagem (corpo-imagem) vai ao encontro do que vamos discutir no decorrer deste trabalho. Como símbolo de beleza, "ela era bonita demais, suave demais, resplandecente [..] Que poder tinha para nos encantar tanto, nos arrebatar, nos dar tanto prazer?", questiona Boris Cyrulnik em sua obra $O$ murmúrio dos fantasmas (2005, p. 1). Ofuscados por tanta beleza, ressalta Cyrulnik (2005, p. 5), "não soubemos ver seu imenso desespero. Ela continuou sozinha na lama onde, de vez em quando, nós lhe jogávamos um diamante... até o dia em que ela se deixou ir embora".

${ }^{24}$ Recuperado em 18 de dezembro de 2017, de http://www.midiario.com/sites/default/files/monroe4.jpg
} 


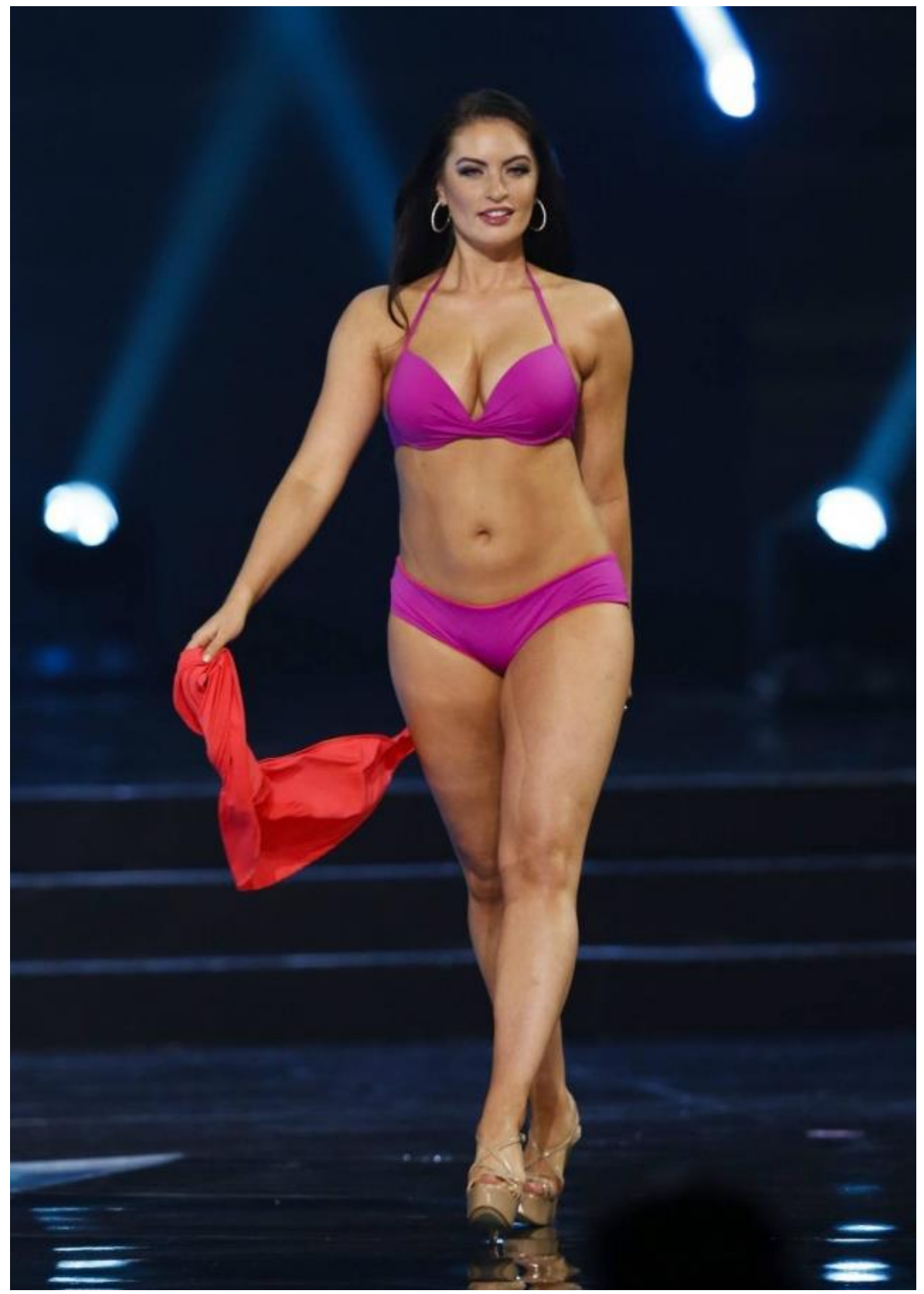

Figura 3. A representante do Canadá, Siera Bearchell, durante o concurso de Miss Universo ${ }^{25}$

Em 1966, as concorrentes a Miss Universo eram "vistosas", pois haviam desenvolvido corpos femininos ideais, com seios grandes e pontudos, cintura fina e quadris redondos. "Sua 
'medidas' eram de suma importância, e 90 centímetros de busto, 60 de cintura e 90 de quadris, o encantamento preferido" (Foxcroft, 2013, p. 15).

Em fevereiro de 2017, a edição brasileira da revista Playboy publicou o primeiro ensaio de uma modelo plus size. A notícia reverberou na mídia e na internet. Nas redes sociais da Playboy, ao anunciar o ensaio com a modelo Fluvia Lacerda, o primeiro comentário feito por um internauta foi: "gorda". "O público masculino quer ver é mulher gostosa", criticou outro leitor. Além dos comentários agressivos dos internautas, o que seria um ato de bravura da Playboy brasileira deixa entrever alguns indícios de que o corpo fora das medidas padronizadas ainda está longe de alcançar a mesma visibilidade dos corpos midiáticos. A edição da Playboy (n. 493) comercializada nas bancas com o ensaio da modelo plus size estampou, em sua capa, a modelo e blogueira Gabriela Rippi. A única menção à modelo plus size acontece em uma das quatro chamadas da capa (Fluvia Lacerda - Into the wild). 


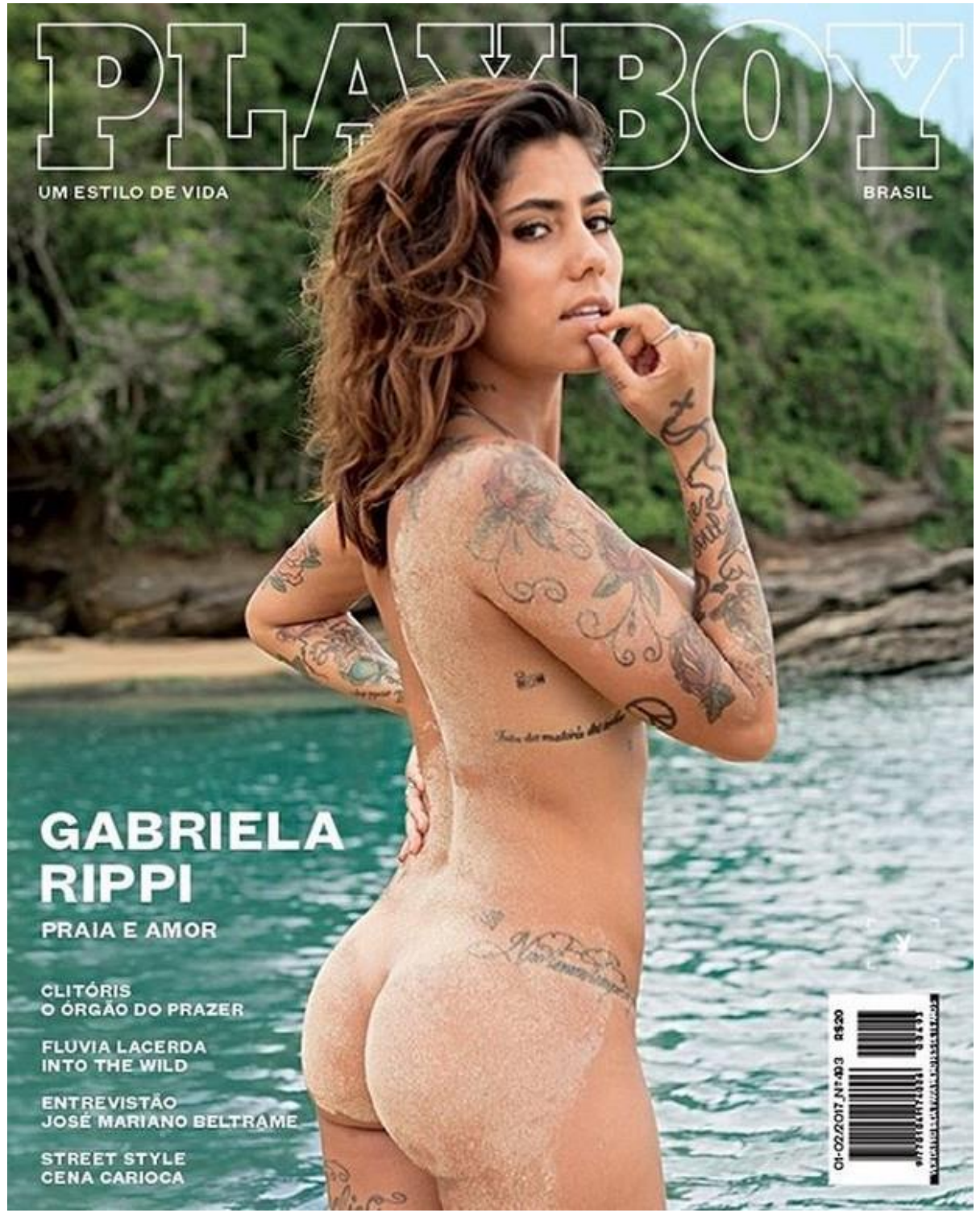

Figura 4. Capa da Playboy com uma pequena menção à modelo plus size Fluvia Lacerda ${ }^{26}$

A publicação que traz em sua capa a modelo Fluvia Lacerda, denominada "edição de colecionador", não circulou nas bancas e só poderia ser adquirida no site da Playboy. As capas das revistas também chamam a atenção pela forma com que expõem suas modelos: Gabriela Rippi está com o dorso nu, de costas, com praticamente todo o corpo à mostra (como disse um site de celebridades, ela está com o "bumbum de fora"). Na edição de colecionador, Fluvia Lacerda é retratada na capa apenas com o rosto (e parte dos seios à mostra).

\footnotetext{
${ }^{26}$ Recuperado em 20 de novembro de 2017, de http://ego.globo.com/famosos/noticia/2016/12/gabi-rippi-posacom-o-bumbum-de-fora-para-capa-da-playboy-veja.html
} 


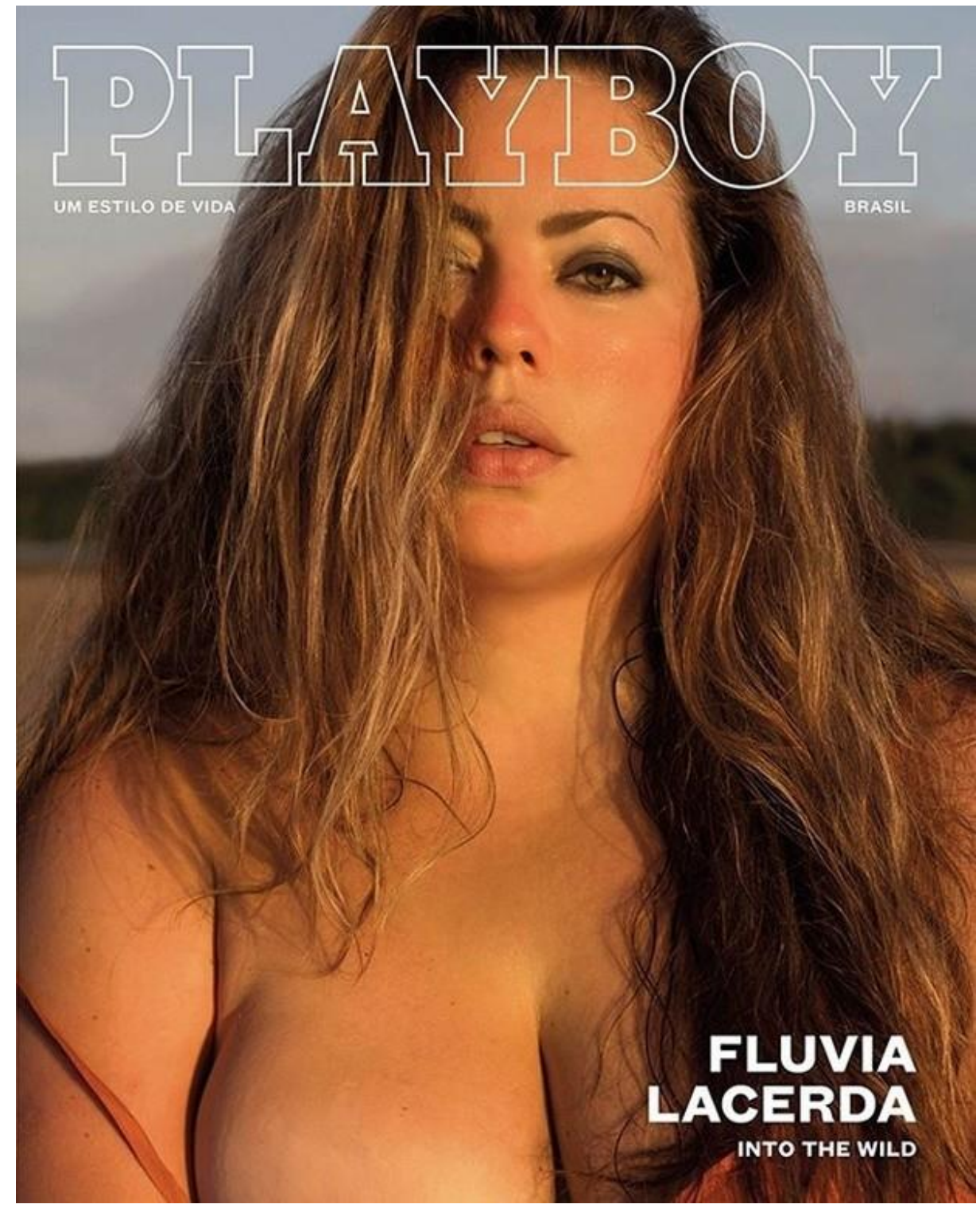

Figura 5. "Edição de colecionador" da revista Playboy com a modelo Fluvia Lacerda ${ }^{27}$

Diante de um cenário midiático que seleciona e incentiva a circulação de determinado formato de corpo, qual o retrato de beleza contemporâneo? Qual o modelo de corpo que preenche os espaços midiáticos? O que um corpo, na contemporaneidade, deve apresentar para ser considerado belo? Quais suas características? Suas proporções? Como a mídia, espaço privilegiado de reprodução e circulação de imagens, discursiviza o corpo feminino? A imagem abaixo fornece alguns indícios, como veremos no decorrer de nosso percurso, para responder a

27 Recuperado em 20 de novembro de 2017, de http://ego.globo.com/famosos/noticia/2016/12/playboydivulga-capa-com-modelo-plus-size-fluvia-lacerda.html 
essas questões. Tida como uma das modelos mais importantes de nossa época, Gisele Caroline Bündchenm foi, por diversas vezes, considerada pela mídia a "modelo mais bonita do mundo".

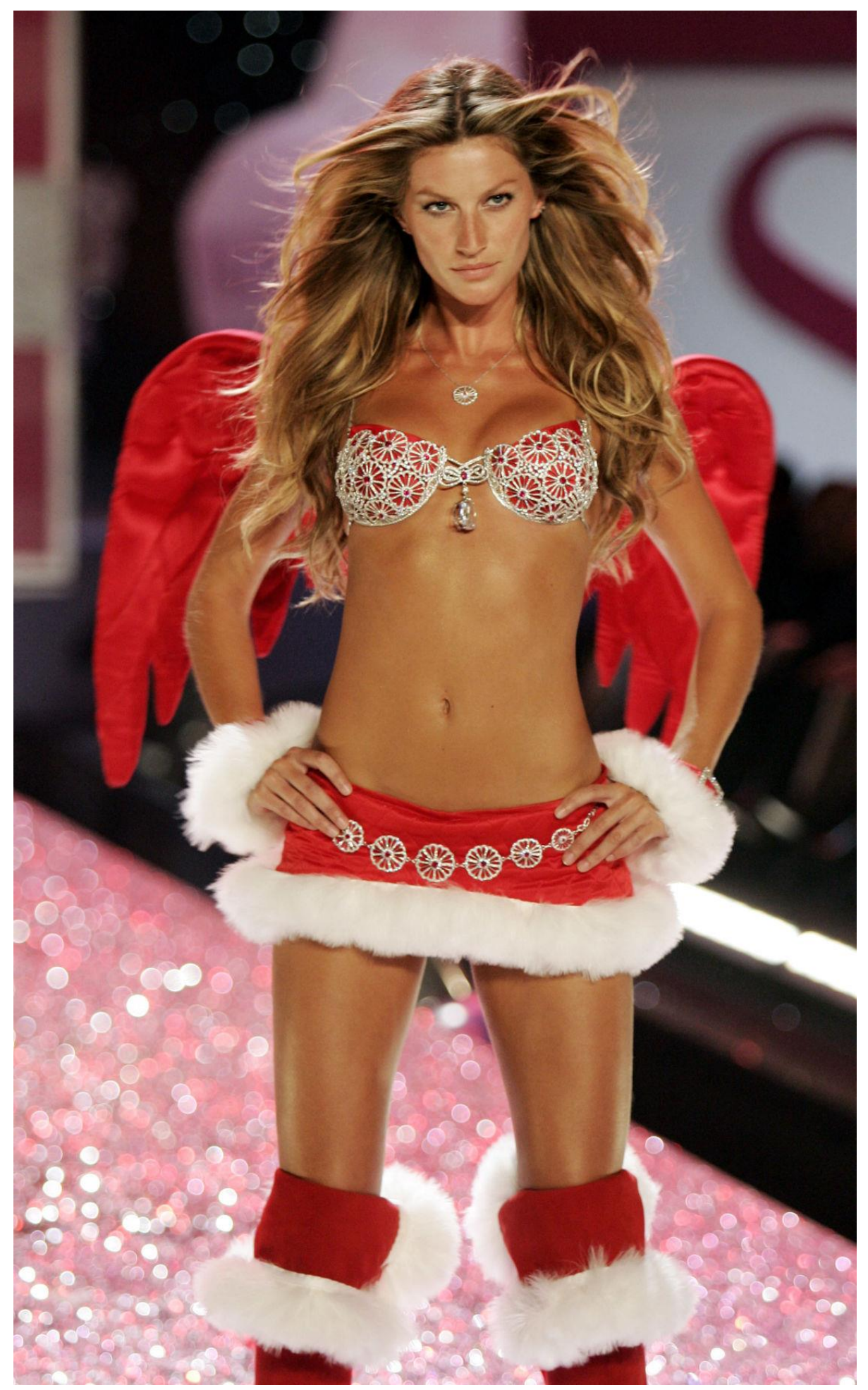

Figura 6. As curvas da modelo Gisele Bündchenm ${ }^{28}$

\footnotetext{
${ }^{28}$ Recuperado em 18 de dezembro de 2014, de http://gente.ig.com.br/giselebundchen/
} 
É fácil notar como o imaginário de beleza atual é o de um corpo que não possui dobras, liso, magro, sem marcas. Esse ideal de beleza contemporâneo também é um conceito importante que aqui trabalharemos: é o que Umberto Eco, em sua obra A História da Beleza (2010) denominou de "a beleza da mídia" ou ainda "a beleza de consumo", de e para o consumo. São efeitos de sentido atribuídos à beleza que consideramos ecléticos e voltados exclusivamente para o consumo. Diferente de ideais de outras épocas da humanidade, cuja beleza apresentava traços mais ou menos específicos, na beleza midiática:

Aqueles que visitam uma exposição de arte de vanguarda, que compram uma escultura "incompreensível" ou que participam de um happening vestem-se e penteiam-se segundo os cânones da moda, usam jeans ou roupas assinadas, maquiam-se segundo o modelo de beleza proposto pelas revistas de capas cintilantes, pelo cinema, pela televisão, ou seja, pelos mass media (Eco, 2010, p. 418).

Uma das vozes dissonantes na questão das dietas é a da nutricionista e pesquisadora Sophie Deram. Em sua obra $O$ peso das dietas: emagreça de forma sustentável dizendo não às dietas, (2014), Deram argumenta que os critérios de beleza atuais são muito diferentes dos de antigamente, quando um corpo mais cheio (especialmente o da mulher) era sinônimo de beleza, saúde e força, e também um sinal de que a mulher podia ter uma gravidez e filhos saudáveis. "Agora, a magreza é cada vez mais valorizada", pontua Deram (2014, p. 54). A beleza midiática é voltada para nichos específicos e assimila diferentes campos estéticos. Pode ser negra como a modelo Naomi Campbell ou a nórdica Claudia Schiffer. Pode conter em uma única peça publicitária elementos estéticos de diferentes estilos e épocas. A beleza midiática do corpoprojeto, que sustenta imaginariamente a Formação Discursiva do universo das dietas (com seu corpo magro e atlético, de dentes brancos e cabelos sedosos e brilhantes, desprovido de rugas e cicatrizes e manchas e dobras e gorduras aparentes) e seus efeitos de sentidos circulam na mídia e constituem um discurso que não dá margem a outros tipos de $\operatorname{corpos}^{29}$ (voltaremos a essa questão no capítulo 3, quando trataremos mais especificamente das condições de produção do discurso das dietas).

\footnotetext{
${ }^{29}$ Sabemos que há, sim, outros modelos de corpos em circulação na mídia, "corpos-de-resistência", como o das modelos "plus size". No entanto, sua circulação é pequena, restrita a nichos específicas do ambiente midiático, ou em alguns casos fazem parte de movimentos de resistência ancorados em sites, blogs ou redes sociais destinadas a combater o modelo de beleza sugerido pela mídia. Durante o desenvolvimento deste trabalho, outros exemplos desse "corpo-contradição" serão mostrados e trabalhados na trama discursiva que aqui pretendemos abordar. Reforçamos, no entanto, que o foco desta pesquisa é justamente os corpos que fazem circular sentidos no discurso midiático das dietas.
} 


\subsubsection{A triste silhueta da tristeza: a ideologia da magreza mira o público infantil ${ }^{30}$}

A valorização da magreza não atinge apenas o público adulto. Durante a realização desta pesquisa, este último nos chamou atenção pela capacidade de sugestionar a questão da magreza para o público infantil. A ideologia predominante do corpo magro faz circular sentidos em diferentes suportes midiáticos. Não apenas nas revistas e sites de boa forma (incluindo todo o espaço virtual como sites, blogs e redes sociais), mas também nos jornais diários, revistas semanais, programas de rádio e TV, cinema.

O filme Divertida Mente (Inside Out, 2015), de Pete Docter, grande sucesso de bilheteria mundial, mostra como as emoções de uma pré-adolescente funcionam em seu cérebro. Cada emoção é caracterizada por um personagem: estão lá raiva, nojinho, alegria, tristeza e medo.

Há cinco anos, o diretor do longa, Pete Docter, convidou o psicólogo americano Paul Ekman para ser consultor científico. Ekman é um dos pioneiros no estudo das emoções e expressões faciais. Em um artigo publicado no jornal New York Times (The Science of 'Inside Out', Keltner e Ekman, 2015) ${ }^{31}$, Ekman relata que discordou de alguns detalhes de como a tristeza foi retratada no filme. A tristeza - diz o psicólogo - é representada como um empecilho, um personagem lento que precisa ser literalmente arrastado pela alegria.

O que Ekman não aborda em seu artigo e que nos chama atenção é a caracterização física das emoções alegria e tristeza. A personagem que representa alegria é alta, magra, uma menina bonita. Já a tristeza é o oposto: uma garota baixinha, com grandes óculos... e gorda. A alegria usa um vestido justo, não muito comprido, que deixa suas pernas e braços magros à mostra. A tristeza usa uma blusa de tricô com gola rolê bem fechada e calça, o que não deixa nada à mostra. Não é uma composição, digamos, muito jovial. Enquanto a alegria possui cintura fina, pernas finas e pescoço alongado, a tristeza é "gordinha", praticamente sem pescoço. A garota responsável pelo nojo, a nojinho, tem cinturinha fina e também usa um vestidinho que deixa braços e pernas à mostra.

\footnotetext{
30 Sob o título "Cinema: triste silhueta", o texto que aborda a questão da escolha do formato dos corpos das personagens Alegria e Tristeza, do filme Divertida Mente, foi originalmente publicado por Rodrigo Daniel Sanches e Maristela Schaufelberger Spanghero no site sobrenossavisãodistorcida.com em 19 de janeiro de 2016. A versão que aqui apresentamos foi alterada em relação ao texto original. Recuperado em 30 de maio de 2016, de http://sobrenossavisaodistorcida.com/post/137580246676/cinematristesilhueta

31 Recuperado em 25 de novembro de 2013, de http://www.nytimes.com/2015/07/05/opinion/sunday/thescience-of-inside-out.html?_r=0
} 
Por que a depressão foi representada como gorda? Se os animadores tentaram caracterizar as emoções de forma a evocar uma imagem correspondente (como no caso do personagem da emoção raiva, vermelho e lembrando uma dinamite pronta a explodir), até acertaram na escolha das cores (azul=blue, é a cor que tradicionalmente representa a tristeza...), mas com certeza não foram precisos na escolha da forma física: é sabido que pessoas que sofrem de depressão, na maioria dos casos, perdem o apetite e emagrecem, às vezes chegando a perder muitos quilos, inclusive. Portanto, não há justificativa para a associação da emoção tristeza com o evidente excesso de peso da personagem. Por que não foi feito o inverso: caracterizar a alegria como uma mocinha baixinha e gordinha e a tristeza como uma garota esbelta e longilínea? Ou então, por que os personagens não foram caracterizados como criaturinhas não humanas como tantas que existem nas histórias infantis? Algo como os Minions (Universal Pictures), do filme de mesmo nome, que conseguem mostrar diferenças de temperamento mesmo sem serem retratados com forma humana? Os animadores de Divertida Mente optaram por caracterizar as emoções alegria, tristeza e nojinho como garotas, com fisionomias humanas, e optaram justamente por caracterizar a alegria com um corpo esbelto, popularmente almejado pelas mulheres, enquanto a tristeza... Por que não o inverso? Ou por que não as caracterizar com a mesma silhueta, com o mesmo "IMC"?

As mulheres consideradas acima do peso recebem vários apelidos nada agradáveis (Foxcroft, 2013): gorda, gorducha, rechonchuda, robusta, acima do peso, grandona, baleia, rolha de poço, fofa, barriguda, pançuda, barriga de cerveja, carnuda, de amplas proporções, obesa, corpulenta, balofa, elefante, jumbo, tamanho GG, bujão, avantajada, gorda feito uma porca, bolota, graúda, inchada, cheinha, volumosa, encorpada, forte, entre tantos outros. Imagine uma criança dizendo para seus pais: "Meu novo apelido na escola é tristeza. Sou baixinha e gordinha - só falta me pintarem de azul". Não bastassem todos os apelidos que uma criança acima do peso escuta durante sua vida escolar, agora elas podem ser chamadas por mais um. Os nomes pejorativos direcionados especialmente às mulheres tidas como gordas indicam que falar sobre gordura corporal implica tocar discursivamente em uma rede com inúmeros fios de tensão, cujos efeitos envolvem violência, intolerância, humilhação, ironia, chacota e repulsa. 


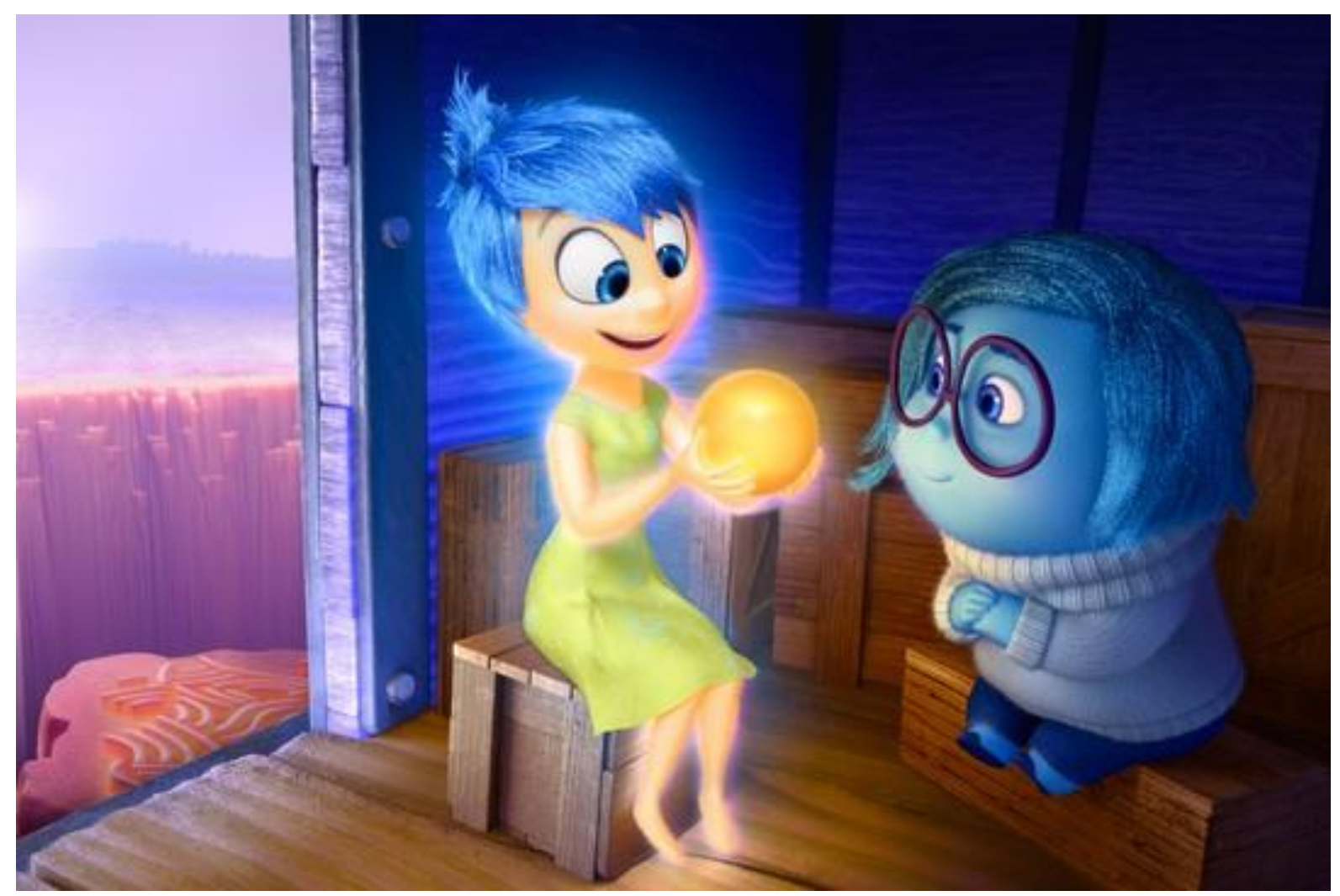

Figura 7. As personagens Alegria (esq.) e Tristeza do filme Divertida Mente ${ }^{32}$

\subsection{O mito do sucesso e da felicidade: Você. Só que melhor!}

A felicidade, diz Urania Tourinho Peres no posfácio da edição brasileira da obra Luto e Melancolia (2011), de Sigmund Freud, não se encontra no plano da criação: é necessário inventá-la. Citando o texto $O$ mal-estar na civilização, Peres relembra o questionamento de Sigmund Freud: "O que revela a própria conduta dos homens acerca de finalidade e intenção de sua vida, o que pedem eles da vida e desejam nela alcançar? É difícil não acertar a resposta: eles buscam a felicidade, querem se tornar e permanecer felizes" (Peres, 2011, p.132).

A explosão de revistas e sites (como o de celebridades americano tmz.com) tornou a mulher ideal menor, mais magra e mais doentia (Foxcroft, 2013). Porém nossos corpos (os não midiáticos) teimam em ser dobras, marcas, sinais, gorduras, manchas, cicatrizes. Uma das estratégias da mídia (que se estende ao mercado das dietas) é o de impor ao sujeito

\footnotetext{
32 Recuperado em 20 de junho de 2016, de https://www.google.com.br/search?q=alegria+e+tristeza+divertida+mente\&biw=1600\&bih=731\&source=Inms \&tbm=isch\&sa=X\&ved=0ahUKEwjj8c-w5oLNAhUHjpAKHXADCgkQ_AUIBygB\#imgrc=6z5G-II6pxaJ6M\%3A
} 
contemporâneo a meta de ser bem-sucedido, no sentido comum de funcionar bem, ter êxito, estar em acordo com certas condições de existência (Payer, 2005), como ter um corpo perfeito. Ao se referir ao mercado, Baitello (2005) argumenta que não é difícil entender as intenções manipuladoras desta pregação diária. Nesse aspecto, ter um corpo perfeito não significa necessariamente ter um corpo saudável, mas visualmente moldado a um determinado protótipo de beleza (os corpos musculosos dos halterofilistas são diferentes dos corpos delgados das modelos do mundo da moda). Esses ideais de beleza - aponta Laus et al (2013) - passam a ser almejados e cultuados, e a não correspondência a esses padrões pode influenciar a percepção da imagem corporal de sujeitos de todas as idades.

Como vimos no início desta pesquisa, se cada época tem um formato de corpo para chamar de seu, cada período da história exige dos sujeitos uma relação especial com as condições de existência mencionada por Payer. Essas condições de existência do sujeito na atualidade são denominadas pela filósofa e historiadora Jennifer Michael Hecht (2009) de "mito da felicidade", isto é, compõem o que uma determinada cultura entende por felicidade. Ela observou que nossa era acredita que a felicidade exige uma relação especial com o exercício físico, alimentos, etiqueta, cultura material e de mídia. Esses cinco aspectos que norteiam a "felicidade contemporânea" são como alicerces que sustentam o discurso midiático das dietas e boa forma, com destaque para o exercício físico, a alimentação e a mídia. Condições que se materializam no formato corporal tramado pela mídia e imposto à mulher como modelo a ser almejado.

E, se vivemos sob a égide do sistema econômico capitalista, essas condições de existência estão igualmente imersas na sociedade de consumidores. Um tipo de sociedade, explica Bauman (2008), formada por um conjunto peculiar de condições existenciais calcado na cultura consumista, cujos homens e mulheres obedecem aos seus preceitos com a máxima dedicação. Forma histórica sujeito-capitalista.

Como quase tudo na vida, há sempre polarizações: se o sujeito direciona suas energias para alcançar um estado de felicidade suprema, é justamente porque o contrário é subjacente a esse processo: quando não estamos felizes, a infelicidade pode se instalar. As condições existências de nossa época indicam ao sujeito "o que os excita e o que os deixa sem entusiasmo a agir e o que os incita a fugir, o que desejam, o que temem e em que ponto temores e desejos se equilibram mutuamente" (Bauman, 2008, p. 70). Como mostraremos durante este trabalho, ao mesmo tempo que o discurso das dietas aponta certas condições para o sujeito "estar no mundo com seu corpo", ao mesmo tempo que o faz desejar um corpo perfeitamente magro, o faz sentir medo e repulsa da gordura e do engordar. Repulsa estética. 
Freud teria elaborado três direções pelas quais o sofrimento nos ameaça. O primeiro deles estaria na fragilidade de nosso corpo, condenado ao envelhecimento e à morte. E a mídia parte justamente dessa premissa, articulando o discurso midiático das dietas e boa forma tendo como alvo a melhoria contínua do corpo, cuja postura é contrária. Envelhecemos. O corpoperfeito enaltecido pela mídia não pode engordar, envelhecer, adoecer, entristecer. O mito da felicidade vai ao encontro do fascínio do sujeito coetâneo por uma condição imposta pelo “enunciado todo-poderoso do mercado, que funciona como lugar máximo de interpelação, e pode ser resumido em uma palavra: sucesso" (Payer, 2005, p. 18). O sucesso é o combustível que move a forma-histórica sujeito-capitalista ou forma sujeito-consumidor-moderno. A felicidade midiática é impregnada de dogmas, que faz reverberar efeitos de sentidos nos quais o agir e o viver na sociedade atual só são possíveis mediante a plenitude em todos os aspectos da vida, uma sensação de potência que é inerente ao sucesso pregado pela mídia e o mercado. E o sucesso se faz presente no formato corporal. A pesquisadora observou que os enunciados de sucesso são produzidos por inúmeros textos que circulam de muitos modos, mas sobretudo através da mídia, no que denominamos ambiência midiática. Um espaço privilegiado que permite, através das tecnologias de informação, produzir, reproduzir e acessar enunciados sobre determinados assuntos a qualquer momento, em qualquer lugar, extinguindo-se as barreiras impostas pelo tempo e espaço. São incontáveis os exemplos que ensinam ao sujeitoleitor como obter sucesso em diferentes áreas, por intermédio de práticas discursivas que circulam em lugares específicos e são construídas especificamente para propagar certos enunciados (Payer, 2005).

As publicações impressas e virtuais que compõem nosso corpus constituem um exemplo claro de espaços midiáticos estruturados para fazer circular enunciados sobre dietas e boa forma. Diz Payer que assim como o templo é o lugar do enunciado religioso, o tribunal é o lugar do enunciado jurídico e o shopping é o lugar dos enunciados do mercado, na nossa análise as publicações sobre dieta e boa forma constituem o lugar por excelência dos enunciados sobre o corpo-perfeito. Ela faz uma ressalva importante: a circulação dos enunciados do mercado não ocorre em um lugar único, mas encontra-se disperso e onipresente através da mídia. Entendemos que os lugares físicos (templos, tribunais, shoppings ou qualquer outra estrutura física), nos dias atuais, têm suas atividades perpassadas pela mídia, uma vez que a ambiência midiática não respeita barreiras físicas, estendendo seus tentáculos a toda ação pública ou privada. Tomamos, como exemplo, o porn revenge (pornografia da vingança), quando um ato que seria praticado na intimidade do sujeito, algo da ordem do privado, passa a ser público e a circular no mundo virtual quando um dos envolvidos decide gravar ou fotografar 
um relacionamento sexual, íntimo, muitas vezes sem o consentimento dos demais envolvidos, e espalhar as imagens pela internet.

No decorrer do nosso caminho de pesquisa, vamos mostrar como as publicações impressas ou virtuais sobre dietas e boa forma ensinam o sujeito-leitor a obter sucesso na formatação do corpo através de regimes, exercícios, alimentação, procedimentos estéticos, etc. Nos dias de hoje, o (re)fabricar-se a si mesmo, como veremos no decorrer de nossas reflexões, é um dos mantras dessas publicações, e isso se materializa no corpo-perfeito. Um corpo que "entra na lógica da circulação e do consumo, tornando-se um empreendimento" (Dias, 2012, p.38). Você está em forma? questiona a todo instante o discurso midiático das dietas e boa forma.

Há vários sites e blogs - todo um universo virtual da boa forma e vida saudável. Somos bombardeados constantemente por um dilúvio de informações sobre dietas, boa forma e vida saudável. Constantemente, diz Botton (2015), o noticiário (seja ele virtual ou não) nos apresenta a um desfile de homens e mulheres extraordinárias, gente capaz de correr mais depressa que qualquer um, que sabe nos fazer rir, que empreendeu negócios revolucionários ou que tem um rosto impecavelmente belo. "Hoje muitas mulheres falham em seus objetivos físicos, gastam muito dinheiro em mensalidades de academia que só usam pela metade e em programas de dieta e, o pior de tudo, se sentem torturadas por seu fracasso" (Hecht, 2009, p. 10). A polarização que abordamos logo acima se faz constantemente presente no discurso das dietas: se a mulher não alcança o corpo-perfeito propagado pelas revistas e sites de boa forma, pode se entristecer com isso. Se um dos pilares do sucesso é o corpo-em-forma, não conseguir formatá-lo de acordo com os ideais de beleza promulgados pela mídia é sinônimo de fracasso. O sucesso e o fracasso são como dois lados da mesma moeda: ou eu tenho sucesso ou me considero (ou sou considerado pela sociedade) um fracassado. Ou a mulher é magra (sucesso) ou gorda (fracassada). Como se a complexidade da vida pudesse se resumir a duas únicas possibilidades.

A capa de todas as edições da revista Women's Health traz, acima do nome da publicação, os dizeres "Você. Só que melhor". Um rol de frases de efeito estampado nas capas sugere ao sujeito um arsenal de exercícios, dietas, procedimentos médicos e estéticos destinados a esculpir o corpo. Para que esse corpo se torne uma versão melhorada, aprimorada, redesenhada, (re)fabricada de acordo com as linhas padronizadas do corpo midiático, do corpoimagem.

E a sociedade midiática é implacável nesse quesito: faça sucesso você também, você pode alcançar o sucesso, tenha sucesso profissional, você pode chegar lá (Payer, 2015). Na 
esteira do sucesso alardeado pela mídia está o corpo-perfeito, magro, atlético, com seus dentes brancos, cabelos sedosos e brilhantes. É o que Baitello denomina “corpo-imagem”:

Cedendo ao assédio, em primeiro lugar, nos transformamos em imagens, seres sem interioridade, sem tempo, que ocupam o espaço reivindicado apenas pelas superfícies. Somos obrigados a viver uma abstração, um corpo sem matéria, sem massa, sem volume, apenas feito de funções abstratas como trabalho, sucesso, visibilidade, carreira, profissão, fama. [...] O destino dos corposimagens é o do envelhecimento precoce das ondas da moda (Baitello, 2005, p. 56).

$\mathrm{Na}$ contemporaneidade, podemos dizer que esse corpo-imagem discursivizado no universo midiático das dietas está intrinsicamente ligado a uma beleza impecável naturalizada pela mídia. Conforme argumenta Sousa (2009), um conjunto de discursos faz os corpos comportarem-se de uma determinada forma ou de outra, ou seja, modelos discursivizados desencadeiam formas-sujeito de um corpo-perfeito (para determinados ambientes da esfera social). E a forma-sujeito histórica tem sua materialidade, diz Orlandi: "o indivíduo, interpelado em sujeito pela ideologia, traz seu corpo por ela também interpelado" (2012a, p. 87). Na perspectiva discursiva, a ideologia é uma prática que constitui, afeta e faz parte do processo de significação do corpo do sujeito (Orlandi, 2012a). Podemos pensar na forma-sujeito corpooperário (para os trabalhadores das fábricas); corpo-executivo (com seus ternos e gravatas de grife); corpo-cabide (modelos extremamente magras que servem de suporte para as roupas mostradas nas passarelas de moda); corpo-placa (homens-placas que anunciam produtos, mais comuns nas grandes cidades); corpo-wearable (corpo atraente não apenas para a passarela, mas para programas de TV, cinema, etc.), entre tantos outros. Não seria possível esgotar, em uma única pesquisa, a infinidade de formas-sujeito e seus corpos.

Somos levados a colocar as doenças que retorcem a figura humana como sinônimo de fracasso pessoal (Sousa, 2009). Estar acima do peso é, na esmagadora maioria das vezes, visto como falta de esforço, comprometimento consigo mesmo ou desleixo do sujeito-capitalista. $\mathrm{O}$ sucesso do qual falamos logo acima está atrelado ao corpo. Um profissional que alcançou o sucesso em sua área de atuação não é bem visto se estiver acima do peso. Em estudos anteriores (Sanches, 2009), já havíamos observado que o sujeito contemporâneo, ao ser interpelado pela ideologia capitalista, é impelido a conceber a si mesmo, a imagem de si mesmo - belo, inteligente, viril, saudável, audacioso, sempre conectado às novas tecnologias ${ }^{33}$. Uma vez que

\footnotetext{
${ }^{33}$ Descrevemos apenas alguns dos inúmeros adjetivos que a publicidade impõe ao sujeito moderno. Há revistas ditas "especializadas" que repisam constantemente as qualidades que o indivíduo contemporâneo deve ter para sobreviver no mundo das grandes corporações. E não basta apenas "ser", é preciso "aparentar" (Sanches, 2009).
} 
o consumidor deve produzir-se segundo a imagem de si mesmo que lhe propõe a publicidade (e a mídia em geral), não há espaço para os corpos distantes dos padrões ideais de beleza, moda e trabalho.

\subsection{A submissão ao design do momento: o corpo magro}

O corpo nada belo

abriga a imperfeição da alma

que busca seu complemento

na insana convivência hipócrita do vazio amor entre as pessoas.

$\mathrm{Bia}^{34}$

Em sua arqueologia das dietas, Foxcroft revela que a formação social e ideológica na qual estamos imersos hoje (dos corpos femininos extremamente magros) teve início nos anos 1920, quando hordas de mulheres solteiras, com suas vidas e expectativas de futuro modificadas pela guerra, propiciaram grandes lucros para o negócio das dietas (como veremos mais adiante, foi também no início dos anos 1920 que a publicidade assumiu as características que a tornam, nos dias atuais, um dos métodos mais eficazes de interpelação do sujeito na direção do consumo e consumismo, uma agência humana, como diz Bauman (2008), dotada de instrumentos de coerção e persuasão).

As lutas da primeira onda feminista e a expansão do consumo, tanto nos Estados Unidos quanto em diversos países, são "dois fenômenos que dialogavam no engendramento de um imaginário sobre a mulher moderna e sua relação emancipadora com o mundo dos bens" (Leal, Freire, \& Rocha, 2016, p. 50). Foi em 1929, por exemplo, que Edward Bernays (voltaremos a falar sobre ele mais adiante) arquitetou um dos grandes episódios de marketing conhecido como Torches of Freedom, quando um grupo de mulheres portando cigarros participou do Easter Sunday Parade, desfile realizado no domingo de Páscoa em Nova Iorque (Estados Unidos). O tabagismo, que até então fazia parte do universo masculino, passava para as mãos femininas como um ato simbólico que reunia rebeldia, liberdade e feminismo. O que estava por trás desse

\footnotetext{
34 Esse pequeno verso estava em uma espécie de "livro" chamado "Corpo", exposto no Museu da Língua Portuguesa da cidade de São Paulo (SP). Não se trata, necessariamente, de uma publicação. Suas páginas em branco podiam ser usadas pelos visitantes, que ali escreviam textos, poemas ou recados, deixando vestígios de sua passagem pelo Museu. A autora do verso identificou-se apenas por "Bia". O museu foi destruído por um incêndio em 21 de dezembro de 2015.
} 
ato: um plano publicitário para expandir o consumo do tabaco tendo como público-alvo as mulheres.

São movimentos como esse que nos levam, a cada dia, a refletir sobre o impacto da mídia (e seus meios de atuação: publicidade, jornalismo, relações públicas, gestão de mídias sociais, etc.), na sociedade contemporânea. Como não é possível prever o futuro, podemos fazer um exercício curioso: daqui a 100 anos, como os pesquisadores abordarão os dias atuais, notadamente marcados pela esfera midiática? Como os historiadores, antropólogos, sociólogos, filósofos, psicólogos e psiquiatras, comunicólogos ou tantos outros pesquisadores das Ciências Sociais (existirão as Ciências Sociais?) irão descrever nossa época? Há algum evento cotidiano na atualidade que não seja marcado pela mídia? O sujeito do século XXI, do despertar ao adormecer, consegue passar um único instante sem ser afetado pela mídia em toda a sua dimensão? A atmosfera midiática que nos envolve será, no futuro, objeto de investigação científica?

A mídia é como um ferrete em brasas: ela nos prensa e deixa marcas. Os fatos históricos de nossa época não podem ser pensados sem o viés ou interferência dos aparatos midiáticos. Não é diferente com as dietas e com os cuidados com o corpo. Enquanto fenômeno midiático, foi nos anos 1920, quando "os papéis femininos vinham sendo discutidos e ressignificados na esfera pública" (Leal et al., 2016, p. 50) que floresciam as novas modas de produtos antigordura. “A expansão da chamada sociedade de consumo no início do século XX foi um elemento importante entre as condições para a emergência de novas subjetividades feminina" (Leal et al., 2016, p. 55).

Em 1922, a revista Vogue questionava se, em breve, haveria uma nova raça de mulheres magras e esbeltas com a ajuda de artifícios como o espartilho, o fisiculturista e a dieta sem amido, já que "a vida era muito mais agradável para as magras e ativas, e um excesso de peso significava inatividade e tédio" (Foxcroft, 2013, p. 136). A modelagem do corpo e a consciência do peso haviam se tornado, nos anos 1920, assuntos de interesses populares de uma forma inédita, e uma das principais razões para isso era a profusão de meios para veicular mensagens sobre emagrecimento.

Em um primeiro aspecto, o corpo vigente na sociedade contemporânea apresenta alguns traços específicos, mas um se sobrepõe de maneira contundente: a magreza. O corpo do sujeito de nossa época deve ser magro. E o indivíduo deve fazer todo o esforço necessário para moldar seu corpo ao padrão vigente da magreza e, portanto, de beleza. Um exemplo é a imagem abaixo, que mostra o esforço de uma celebridade para emagrecer em um curto espaço de tempo: 


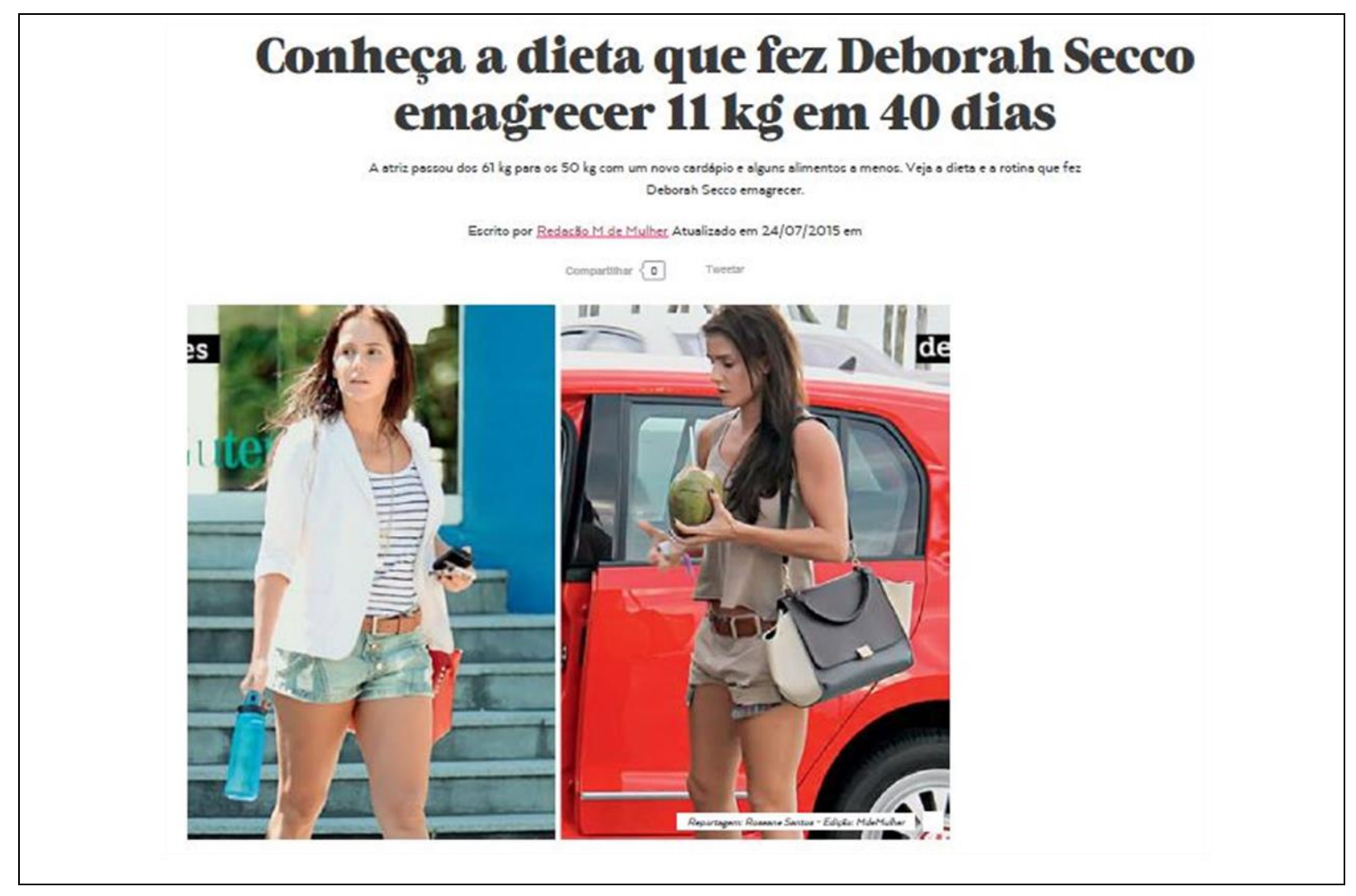

Figura 8. Imagem reforça a magreza da celebridade após regime ${ }^{35}$

O segundo aspecto não está, necessariamente, no formato do corpo, mas nas supostas facilidades que a contemporaneidade oferece ao indivíduo que busca moldá-lo ao parâmetro vigente em nossa época. E isso ocorre principalmente por intermédio do virtual, ou melhor, do entrelaçamento do sujeito com o virtual - a conexão permanente que permite receber, produzir e disseminar todo tipo de informação em uma velocidade jamais vivenciada pela humanidade. A notícia da celebridade que emagreceu 11 quilos em 40 dias está à disposição de todos, em qualquer lugar, a qualquer hora. Basta um dispositivo tecnológico (computador, celular, tablet) e acesso à internet e, em alguns segundos, o sujeito tem acesso ao texto e a imagem que, no recorte acima, mostra o formato do corpo da atriz antes e depois da dieta, vangloriando sua nova silhueta. Diz Le Breton (2003) que, em nossas sociedades, a parcela de manipulação simbólica ampliou-se a tal ponto que o reservatório de conhecimento e de serviços à disposição dos indivíduos estendeu-se desmesuradamente ${ }^{36}$.

\footnotetext{
${ }^{35}$ Recuperado em 20 de junho de 2016, de http://mdemulher.abril.com.br/dieta/m-trends/conheca-dieta-quefez-deborah-secco-emagrecer-11-kg-em-40-dias

${ }^{36}$ Michel Pêcheux (2011) enfatiza que a propaganda (o que também pode ser empregado na publicidade) e suas práticas estão ancoradas em uma "bio-psicologia", dando sustentação as condições técnicas-discursivas de
} 
Não seria possível esgotar em um único trabalho todos os aspectos relacionados a essa questão (que venho me debruçando desde o Mestrado). No entanto, no enredo midiático das formações ideológicas da boa forma podemos destacar alguns cenários e protagonistas:

- o interesse do indivíduo em adequar-se ao padrão corporal vigente;

- a indústria das celebridades, com seus corpos perfeitos estampando revistas, publicidade de produtos de todo tipo, sites e blogs que impõem um determinado formato de corpo. Há uma gama de profissionais que oferecem os recursos necessários (e cobram caro por isso), sugerindo "as loucas dietas da moda, os remédios para emagrecimento e as manipulações artificiais - necessários para nos espremer e nos obrigar a corresponder a uma norma inatingível de perfeição que nos rouba a dignidade, o dinheiro e a saúde" (Foxcroft, 2013, p. 21);

- o virtual que, na esteira das tecnologias de comunicação e informação, pode ser acessado a qualquer momento e lugar, sempre com informações sobre as últimas novidades das dietas, exercícios, produtos, celebridades que emagreceram, blogs de compartilhamento de informações entre sujeitos que pretendem emagrecer. 


\section{Capítulo 3}

\section{ALGUMAS QUESTÕES QUE NOS INCOMODAM, E (RE)CLAMAM POR INTERPRETAÇÃO}

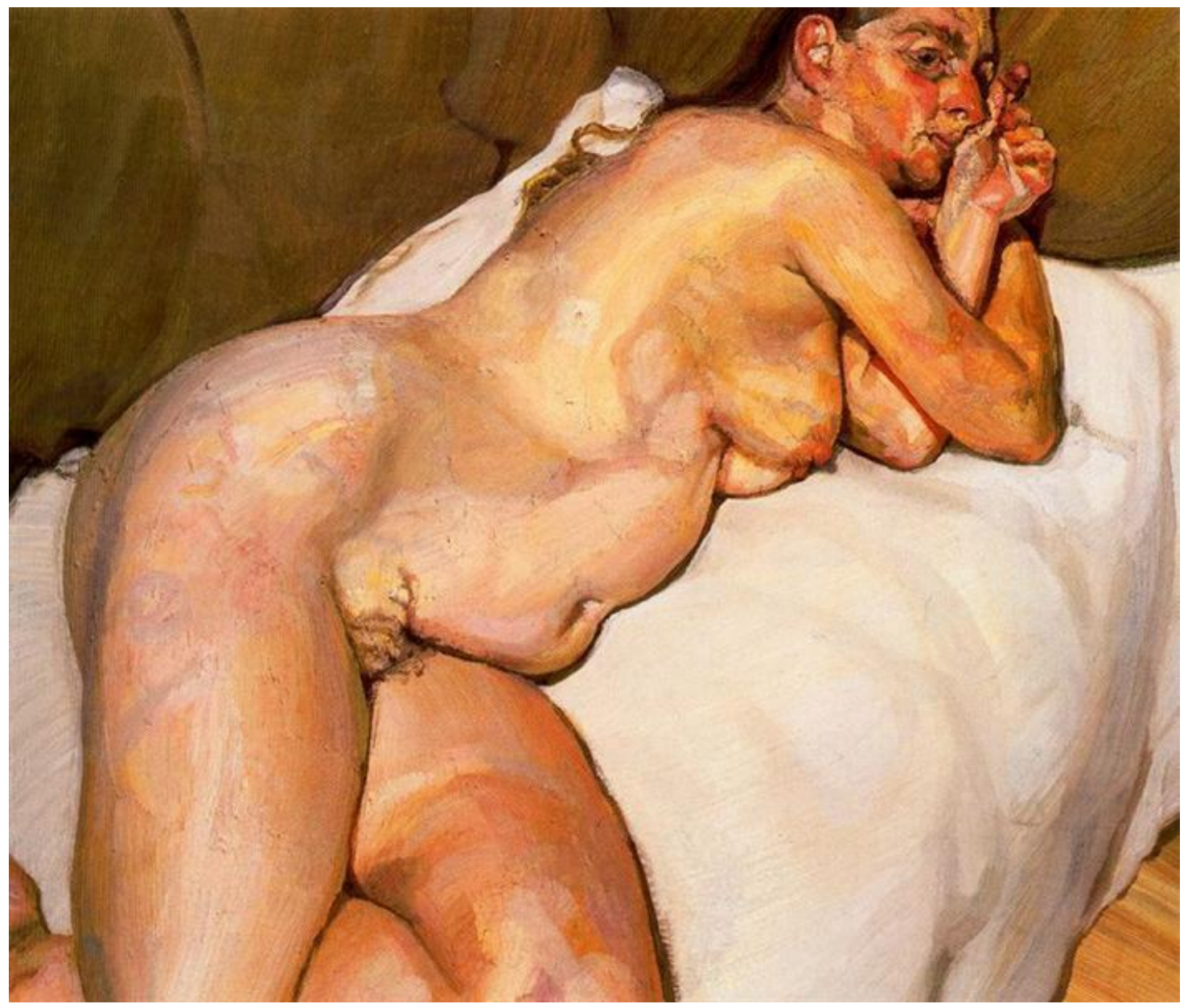

Naked Woman on a Sofa (Lucian Freud, 1984-1985)

A palavra escrita representa algo que eternamente nos engana.

Henry James

Deve haver, ainda assim, na palavra um conceito. Johann Wolfgang von Goethe 


\subsection{As condições de produção do discurso midiático das dietas: a naturalização de alguns sentidos e o silenciamento de outros}

O trajeto percorrido até este momento e que continuaremos a percorrer aponta que o discurso midiático das dietas e boa forma, presente em nosso corpus, é produzido sob certas condições de produção, fios que se entrelaçam e resultam em um tecido de evidências no qual se constituem os sentidos e o sujeito-consumidor das dietas. As condições de produção, afirma Orlandi (2009), compreendem os sujeitos, a situação e a memória. Em sentido estrito, temos as circunstâncias da enunciação. Em sentido amplo, as condições de produção incluem o contexto sócio-histórico e ideológico. A questão da memória (interdiscurso) das dietas e do corpo foi abordada no capítulo 2 (efeitos midiáticos da perda de peso; a imagem arde).

Para compreendermos as condições de produção do discurso das dietas, partiremos do contexto amplo para depois analisarmos o contexto estrito, imediato. Podemos afirmar que o contexto sócio-histórico e ideológico é formado por vários elementos condicionados ao funcionamento da sociedade. É nesse contexto mais amplo que reside a constituição dos dizeres sobre dietas e corpos, a partir de uma memória do dizer que faz intervir o contexto históricoideológico mais amplo (Orlandi, 2005). Até o momento, já discorremos sobre alguns deles. Primeiro: o corpo é resultado de uma construção sócio-histórica. O segundo aspecto repousa no fato de que nossa época abomina a gordura e os corpos gordos; o formato do corpo contemporâneo deve ser magro. Terceiro: vivemos sob o domínio ideológico do capitalismo e do consumo, isto é, sob a forma sujeito-capitalista. A partir de agora, abordaremos outros elementos que compõem, no nível mais amplo, as condições de produção do discurso das dietas. São eles: o texto da mídia (Payer, 2015), ferramenta do mercado que trabalha incessantemente para incitar o consumo, em especial à publicidade, em uma ambiência midiática de produção e circulação de informações; a ambiência tecnológica, midiática por essência, que estabelece um fluxo contínuo de produção e circulação da informação ao invadir os ambientes públicos e privados através das tecnologias de comunicação, especialmente as sem fio. Forma histórica sujeito-conectado. Durante este trabalho, falaremos mais sobre as condições de produção em sentido estrito, como a linguagem publicitária.

Ao impor ao sujeito coevo a meta de ser bem-sucedido, o texto da mídia faz circular efeitos de sentidos de auto realização: só depende de cada um obter as medidas do corpoperfeito, da forma sujeito corpo-projeto (você, só que melhor!). Um corpo feito de imagens e imaginários produzidos pela mídia, inalcançável para a maioria de nós. Mas a mídia (em 
especial o marketing) insiste em usar todos os subterfúgios possíveis para interpelar o sujeito e dizer-lhe que seu corpo ainda não alcançou os patamares de excelência: faça mais exercícios, compre novos medicamentos para emagrecer, alimente-se adequadamente, consuma todas as novidades para você sonhar acordado com o projeto de um corpo soberano.

Nesse contexto observamos e continuaremos a focar na ideologia do corpo-projeto (um corpo-imagem), que fornece evidências que fazem com que os enunciados das dietas e suas novidades queiram dizer o que realmente dizem, sob o efeito da transparência da língua. Atuando segundo certas condições de produção, as formações ideológicas das dietas favorecem um ambiente do que pode e deve ser dito sobre o corpo na atualidade, interpelando o sujeito e interferindo em suas formas de assujeitamento. Não se pode quantificar o assujeitamento, explica Orlandi (2005, p. 100): “a subjetivação é uma questão de qualidade, de natureza: não se é mais ou menos sujeito, não se é pouco ou muito subjetivado [...] Não há nem sentido nem sujeito se não houver assujeitamento à língua”. Um grupo de mulheres discutindo sobre dietas e emagrecimento está, necessariamente, assujeitando-se à linguagem presente no discurso midiático das dietas e boa forma. Como mostramos no início de nossa reflexão, a dieta, para os gregos, não estava necessariamente atrelada à perda de peso. $\mathrm{Na}$ atualidade, com a ressignificação dos efeitos de sentidos da dieta pela mídia, dedicar-se a uma dieta é sinônimo de EMAGRECIMENTO. Sujeito e sentido se constituem mutuamente. Pêcheux (2009) ilustra que é trabalho da ideologia criar e sustentar um efeito de evidência nos sentidos, velando ao sujeito outros sentidos diferentes dos legitimados (dieta é o ato de emagrecer; um corpo belo é um corpo magro; estar acima do peso é sinônimo de desleixo). "Quando dizemos que o sujeito, para se constituir, deve-se submeter à língua, ao simbólico, é preciso acrescentar que não estamos afirmando que somos pegos pela língua formal, mas sim pelo jogo da língua na história, na produção de sentidos" (Orlandi, 2005, p. 102).

O sujeito moderno, teoriza Gregolin (2007, p. 21), “é um consumidor de subjetividade: ele consome sistemas de representação, de sensibilidades”. Como já vimos anteriormente em alguns recortes e veremos nos próximos, a formação ideológica do corpo-projeto faz circular formações discursivas que cristalizam determinados dizeres e efeitos de sentidos sobre dietas, apagando tantos outros possíveis. No discurso das novas dietas, dieta é sinônimo de emagrecimento. Emagrecer é sinônimo de beleza e vida saudável. Para ser saudável não é possível estar acima do peso. A ambiência midiática das dietas promove a saturação dos sentidos. O ciclo das evidências é encerrado em torno de si mesmo. O corpo-projeto é similarmente um protótipo de corpo, um exemplar exato cujas proporções devem ser reproduzidas à exaustão. 
Conforme relatei no início deste trabalho, em uma primeira tentativa de abordar práticas socioculturais e sua relação com a linguagem contemporânea, procurei investigar como o discurso publicitário e a cultura tecnológica operam para criar imagens, conceitos, discursos para um mundo do consumo (de imagens e coisas). Durante todo processo de desenvolvimento daquela pesquisa, dediquei-me aos estudos do discurso publicitário e midiático e suas consequências: como as imagens pré-concebidas e distribuídas pelos dispositivos (dos mais arcaicos aos revestidos de alta tecnologia e performance) moldam e modificam a percepção do corpo contemporâneo, afetando processos culturais e de subjetivação (Sanches, 2009). A base daquele estudo foi a análise de corpos que podem ser entendidos como suportes midiáticos (homem-placa, homem-placa-virtual, garotas-panfleto, corpo-cabide, corpo-executivo, corpomáquina, entre outros).

Como pude observar naquele primeiro momento, a mídia implica em uma nova qualificação da vida através de novos processos culturais. Ao refletir sobre a relação íntima e estreita entre linguagem, sujeitos e sociedade, Payer (2005) aponta que a contemporaneidade oferece muitas questões que nos incomodam, e cabe a cada um de nós tentar identificar e prover de sentidos em alguma direção que valha a pena. Neste trabalho, apontaremos para uma direção específica na tentativa de compreender alguns dos sentidos produzidos pelas atuais pautadas na economia de mercado: a relação do sujeito e os sentidos provenientes do discurso midiático das dietas e suas novidades. As condições de produção do discurso das dietas são marcadas profundamente por alguns aspectos que efetivamente nos incomodam: o "texto do mercado" ou "texto da mídia", a publicidade e sua linguagem (materialidade significante composta por imagens e textos atuando em conjunto), o consumo e a tecnologia. Vamos nos ater a cada uma delas, porém sabemos que são pontos que se entrelaçam, atuando sob um grande guarda-chuva que compõe as formações social, ideológica e discursivas do universo das dietas.

Antes de avançarmos, precisamos fazer uma ressalva em relação ao nebuloso conceito de "mercado". Quantas vezes lemos nos jornais notícias com os títulos: "Mercado ignora exterior e reage a eleição"; "Mercado reage a especulações e juros futuros sobem"; "Mercado reage bem à queda nos juros; dólar cai e Bolsa sobe". Mas quem é ou o que é o "mercado"? Quando Payer refere-se ao "texto do mercado", o que vem a ser essa instituição? O mercado, explica Baitello (2005), é um entre tantos textos culturais elaborados pela inventividade humana: é uma relação comunicativa, uma criação social, uma rede complexa de relações comunicativas, um ser de ficção, não uma entidade autônoma com poderes para isso ou aquilo. “Será um exercício de pensamento mágico-mítico acreditar que ele em si possa regulamentar 
algo, já que sua intencionalidade reside na intencionalidade de seus participantes" (Baitello, 2005, p. 77).

Por sua vez, ao operar discursivamente o mercado produz efeitos de sentidos ao exigir dos sujeitos certas condições de existência. "Quais são as formas de linguagem e de sujeito que vêm sendo requisitadas nas atuais condições de produção, que se apresentam fundamentalmente nas formas da globalização econômica?”, questiona Payer (2005, p. 11). Em outras palavras, qual a influência que o entrelaçamento entre mercado, capitalismo, globalização e mídia exercem sobre os sujeitos na contemporaneidade? Uma das possíveis respostas a essa questão está no filme Rede de Intrigas (Network, 1976), dirigido por Sidney Lumet. Howard Beale, um apresentador de uma rede de televisão que é demitido devido à baixa audiência do programa, anuncia que irá cometer suicídio no ar. Os índices de audiência do programa voltam a crescer, e ele passa a ser conhecido como o "Profeta Louco". Em um de seus programas, Beale faz duras críticas a um negócio milionário envolvendo a companhia para o qual trabalha e um grupo árabe. Após esse episódio, ele é chamado a ter uma conversa com Arthur Jensen, um dos homens que controlam o conglomerado de mídia detentor da emissora de TV onde Beale apresenta seu programa. Alternando berros e uma cínica e meticulosa calmaria, Jensen explica ironicamente à Beale o que significa a economia no mundo globalizado:

You have meddled with the primal forces of nature, Mr. Beale. And I won't have it! Is that clear? You think you've merely stopped a business deal. That is not the case. The Arabs have taken billions of dollars out of this country and now they must put it back! It is ebb and flow, tidal gravity, it is ecological balance! You are an old man who thinks in terms of nations and peoples. There are no nations, there are no peoples! There are no Russians! There are no Arabs! There are no Third Worlds! There is no West! There is only one holistic system of systems. One vast and immane, interwoven, interacting, multi-variate multinational dominion of dollars. Petrol dollars, electrodollars, multi-dollars. Reichsmarks, rins, rubles, pounds and shekels! It is the international system of currency which determines the totality of life on this planet. That is the natural order of things today! That is the atomic and subatomic and galactic structure of things today! And you have meddled with the primal forces of nature! And you will atone! Am I getting through to you, Mr. Beale? You get up on your little 21-inch screen and howl about America and democracy. There is no America. There is no democracy. There is only IBM and ITT and AT\&T and Dupont, Dow, Union Carbide, and Exxon. Those are the nations of the world today. What do you think the Russians talk about in their councils of state? Karl Marx? They get out their linear programming charts statistical decision theories, minimax solutions and compute the price-cost probabilities of their transactions and investments just like we do. We no longer live in a world of nations and ideologies, Mr. Beale. The world is a college of corporations inexorably determined by the immutable bylaws of business. The world is a business, Mr. Beale. It has been since man crawled out of the slime. And our children will live, Mr. Beale, to 
see that perfect world in which there's no war or famine, oppression or brutality! One vast and ecumenical holding company for whom all men will work to serve a common profit in which all men will hold a share of stock, all necessities provided, all anxieties tranquillized, all boredom amused ${ }^{37}$.

Quando nos deparamos com a palavra "mercado", descreve Sodré (2003), estamos diante de um paradigma, "voltado para a estruturação das formas de elaboração da realidade" (p. 28). A economia de mercado, continua, pode ser "traduzida como resultado de uma natureza eterna e imutável do homem e, assim, legitimada com todas as suas distorções junto à consciência do homem comum, pouco afeito à complexidade técnica do processo econômico" (Sodré, 2003, p. 35). E a economia não é algo estanque, apartado do cotidiano, mas imerso nas relações sociais. "It is the international system of currency which determines the totality of life on this planet. That is the natural order of things today", explica Jensen à Beale. Resume Sodré (2003, p. 32): “de simples função da organização social, o sistema econômico, por intermédio do mercado, faz da sociedade humana seu acessório". Toda vez que citarmos neste trabalho os conceitos mercado, capitalismo, economia ou globalização, lembremos do diálogo entre Jensen e Beale.

\subsection{O texto da mídia}

\footnotetext{
37 "Você se meteu com as forças primárias da natureza, Sr. Beale, e não permitirei isso. Está claro? Acha que simplesmente impediu um negócio. Não é este o caso. Os árabes já tiraram bilhões de dólares deste país, e agora precisam colocá-los de volta! É fluxo e refluxo, a maré. É equilíbrio ecológico! Você é um velho que pensa em termos de nações e povos. Não há nações. Não há povos. Não há russos. Não há árabes. Não há Terceiro Mundo. Não há ocidente. Há apenas um único sistema holístico de sistemas! Um domínio vasto e total, entrelaçado, interagindo, multi-variante, multinacional de dólares! Petrodólares, eletrodólares, multidólares, marcos, rublos, libras e shekels! É o sistema monetário internacional que determina a totalidade da vida neste planeta. Essa é a ordem natural das coisas hoje em dia. Essa é a estrutura atômica e subatômica e galáctica das coisas hoje em dia! E o senhor se meteu com as forças primárias da natureza! E vai pagar por isso! Está me entendendo, Sr. Beale? O senhor vai na sua televisão de 21 polegadas e rosna sobre a América e a democracia. Não existe América. Não existe democracia. Existe apenas IBM, ITT e AT\&T e Dupont, Dow, Union Carbide e Esso. Essas são as nações do mundo de hoje. Do que você acha que os russos falam nos conselhos de estado? Karl Marx? Eles pegam seus gráficos lineares de programação, teorias estatísticas de decisão, soluções minimax e calculam as probabilidades do preço e do custo de seus investimentos, assim como nós! Não vivemos mais em um mundo de nações e ideologias, Sr. Beale. O mundo é um grupo de corporações inexoravelmente determinadas pelos estatutos imutáveis dos negócios. O mundo é um negócio, Sr. Beale. E tem sido assim desde que o homem saiu do lodo. E nossos filhos viverão, Sr. Beale, para ver um mundo perfeito no qual não há guerra ou fome, opressão ou brutalidade. Uma companhia controladora vasta e ecumênica para a qual todos os homens servirão para o lucro comum da qual todos terão uma parcela, todas as necessidades serão satisfeitas, todas as ansiedades serão tranquilizadas. Todo tédio será exterminado". Livre tradução do autor.
} 
Em Psicobiologia do Comportamento Alimentar (Laus et al, 2013), os autores empregam o termo mídia a todos os veículos utilizados para divulgação de conteúdos de publicidade e propaganda, alertando para a frequente veiculação de mensagens com efeitos bastante persuasivos. Trata-se de um conceito correto, mas que deve ser ampliado. Norval Baitello Jr. (2005) explica que a palavra 'mídia' tem uma história bastante simples, significa 'meio'. É uma palavra antiquíssima: vem do latim medium, que deu em português também a palavra médium e, nos Estados Unidos, retornou ao espaço latino com pronúncia americanizada. A pronúncia americanizada, ou anglicizada, se transformou em escrita. No Brasil, onde perde o sentido plural, passou a se escrever mídia, transcrição da pronúncia inglesa para o plural latino de medium, que tanto em latim quanto em inglês se escreve media. Mas a palavra tem raiz no indo-europeu, a língua ancestral da qual vêm o latim e quase todas as outras línguas europeias, sendo grafada medhyo, e já significava meio, espaço intermediário (Baitello, 2005). Em uma primeira análise, a mídia é aquilo que está entre um indivíduo ou organização que pretende veicular algo e o espectador.

Em muitos casos a palavra mídia arrasta consigo efeitos de sentidos atrelados à comunicação, aquilo que faz o meio de campo comunicacional. Portanto, não se refere apenas à publicidade e propaganda, mas a todo sistema de veiculação de mensagens, que pode ser jornalístico, radiofônico, virtual (internet), entre outros. Pode ser uma simples troca de mensagens entre dois indivíduos através de um aparelho celular. Ou um bilhete escrito à mão e grudado na geladeira. Muitas vezes a palavra mídia é reduzida ao mero sentido de suporte midiático: a mídia rádio, a mídia televisiva, a mídia impressa. Silverstone (2005) salienta que a mídia deve ser estudada não apenas como divulgação de conteúdo, mas também em sua dimensão social, cultural, política e econômica, como algo que contribui para nossa capacidade de compreender o mundo, produzir e partilhar significados sobre o mundo. Ampliamos a nossa reflexão do conceito mídia para citar algo ainda mais importante do ponto de vista dos processos de produção e circulação dos sentidos: o ambiente comunicacional ou ambiência midiática. Um ambiente complexo, onde "cada coisa ou pessoa gera em torno de si um ambiente saturado de possibilidades de comunicação" (Baitello, 2010), de possibilidades de produção e circulação de sentidos.

A sociedade sem fio (Bauman, 2008), em alusão à sociedade cada vez mais conectada, exige dos sujeitos novas maneiras de se relacionar com o ambiente midiático, demanda do sujeito um certo tido de competência comunicativa multifacetada, "requisito indispensável para as relações entre interlocutores de um novo mercado global” (Payer, 2005, p. 12). Se as condições de existência na atualidade, o "estar no mundo" exige uma afiliação à forma histórica 
sujeito-capitalista, elas impõem ao homem, igualmente, a forma histórica sujeito-conectado. Como vimos anteriormente, as revistas de boa forma recebem dos seus sujeitos-leitores as mensagens que podem ser publicadas nas próximas edições através de redes sociais. Com o advento das redes sem fio (wireless), essa mensagem pode ser enviada através de um suporte midiático conectado à internet (smartphones, tablets, notebooks), a qualquer hora e em qualquer lugar. Como veremos no decorrer deste trabalho, a sociedade sem fio trouxe profundas mudanças no tecido social, influenciado a maneira como o sujeito consome, produz e faz circular discursos. Em especial no que tange à velocidade de produção e circulação dos discursos no ambiente virtual.

Esse cenário midiático (que abrange as tecnologias de comunicação e informação e todas as formas de formulação e circulação dos discursos) faz emergir o que Payer (2005) denominou "texto da mídia", um conceito que ecoa nas reflexões de Botton (2015) acerca do noticiário veiculado pelos mais diferentes suportes midiáticos. Ele argumenta que, segundo Hegel, as sociedades se modernizaram quando o noticiário passou a ocupar o lugar da religião como principal fonte de orientação e como referência de autoridade. Se há algo que o noticiário sabe habilmente evitar, diz Botton (2015), é a posição predominante que passou a ocupar em nossas vidas.

Segundo Payer (2005), por volta do século XVI produziu-se socialmente uma transformação histórica do predomínio do poder, que se transferiu da Religião para o Estado. Na Idade Média, a forma da estrutura social era organizada segundo a obediência às leis divinas. Com a Revolução Francesa, transferiu-se o poder de organização social para o Estado. Através de regulamentações jurídicas, os indivíduos deixaram de ter o estatuto de escravos para se tornarem cidadãos. Na sociedade contemporânea - conclui Payer (2005) - alguns fatos da linguagem indicam uma nova transformação nas formas de poder, acompanhadas por mutações na constituição da forma do sujeito. Em cada período da história, há enunciados que funcionam como fundamentais, enquanto máximas capazes de condensar o conteúdo a exercer a interpelação ideológica dos sujeitos.

Podemos dizer que a mídia ocupa hoje, portanto, o status do discurso religioso na Idade Média e da lei jurídica na ordem do Estado Moderno ${ }^{38}$ :

Este grande texto da atualidade, no meu modo de entender, consiste da Mídia, daquilo que está na mídia, em um sentido amplo, e em especial no marketing, na publicidade. $\mathrm{O}$ valor que a sociedade vem atribuindo à mídia - ou o poder

\footnotetext{
${ }^{38}$ Tanto as religiões quanto o Estado seguem ocupando papéis importantes na atualidade. No entanto, a mídia tem se mostrado, por suas especificidades, extremamente eficaz na interpelação do sujeito contemporâneo.
} 
de interpelação que a Mídia vem exercendo na sociedade - passa a assegurarlhe o papel de Texto fundamental de um novo grande Sujeito, o Mercado, agora em sua nova forma globalizada (Payer, 2005, p. 16 - grifos nossos).

A mídia coloca-se como autoridade ao ocupar a posição de relator de dizeres que circularão no espaço público, um "poder-dizer" que ocupa uma posição que poucos podem ocupar, fazendo circular um discurso que é considerado mais confiável, fiel e digno de crédito (Romão, 2009). A comunicação em nossa época é, inevitavelmente, marcada pela mídia, que exerce influência direta na configuração dos imaginários sociais (Moraes, 2003). Nesse sentido, Botton (2015) ironiza ao dizer que a manchete "Metade da humanidade é hipnotizada todos os dias pelo noticiário" tem poucas chances de algum dia ser noticiada por empresas que em geral se dedicam a relatar o que consideram digno de nota.

O texto da mídia, em suas novas formas proporcionadas pelo desenvolvimento da tecnologia, e sobretudo da imagem, opera com especial força pragmática sobre os indivíduos. É o que Kamper (2016, p.70) intitulou “máquinas de olhar e de imagem”, que não são apenas instrumentos ou ferramentas, mas "projetos de mundo com ambições totalitárias". Para o pesquisador da comunicação Muniz Sodré, a mídia é a boca do mercado. Payer (2005) também confere à mídia o mesmo status, argumentando que ela pode ser considerada como o texto fundamental do mercado. Mídia e mercado atuam em uma via de mão dupla: a mídia funciona legitimando as ações do mercado, atuando na constituição e naturalização de sentidos vistos como necessários ao processo de organização e atuação das corporações, que usam os recursos midiáticos para legitimar sentidos e garantir as condições para a realização de suas ações. Em síntese, para promover e expandir o consumo.

Em relação ao ambiente midiático, podemos observar as condições de produção do discurso das dietas tanto no contexto imediato quanto no contexto mais amplo. Expliquemos. O contexto sócio-histórico e ideológico do discurso das dietas é constituído, como vimos, pelas questões históricas e culturais sobre o corpo, o domínio ideológico do capitalismo e a incitação ao consumo. Já a ambiência midiática tem seu núcleo composto pelas empresas de mídia, atuando em um cenário no qual o texto da mídia se faz onipresente na vida social e prática. Soma-se a isso a facilidade e velocidade com que os discursos midiáticos circulam na atualidade, ancorados nas tecnologias de informação e comunicação. Em um contexto estrito, podemos observar a formulação do discurso das dietas, que acontece em condições de produção e circunstâncias de enunciação específicas (Orlandi, 2005). Esse discurso é formulado por publicações (impressas e virtuais) que se auto intitulam "boa forma" e "vida saudável". Esse discurso nasce de corporações de comunicação que tomam para si o poder de ensinar a mulher 
sobre emagrecimento, vida saudável, alimentação, beleza, relacionamento, sexo, atividade física, carreira, entre outros tantos temas. Tanto no texto midiático das dietas quanto nos comentários dos sujeitos-leitores produzidos nas plataformas de mídia (sejam elas impressas ou virtuais), a linguagem sobre dietas "ganha vida, que a memória se atualiza, que os sentidos se decidem, que o sujeito se mostra - e se esconde”, diz Orlandi (2005, p. 9). Isso ocorre em uma via de mão dupla, continua a pesquisadora, tanto na materialização da linguagem em sentidos quanto nos sentidos tomando corpo, em um transcurso no qual corpo e sentido se atravessam.

As publicações assumem um "poder dizer", um status poderoso e lucrativo que influencia diretamente a linguagem (como veremos mais adiante) e os efeitos provenientes desse discurso. Esses manuais sobre dietas e boa forma englobam uma série de dicas, discursivizando sentidos naturalizados sobre o corpo, beleza e saúde. Essas dicas midiáticas, ressalta a nutricionista Sophie Deram (2014), essas informações que as publicações divulgam são, na maioria das vezes, sensacionalistas, simplificadas, às vezes contraditórias, baseadas em uma pseudociência: “a mensagem não é tão precisa e pode incentivar comportamentos contraditórios" (p.60). Como mostramos no capítulo 1, algumas publicações estão há mais de três décadas produzindo discursos e sentidos sobre dietas, e lucrando com isso.

As empresas que constituem a chamada mídia também fazem parte deste mesmo mercado, ou seja, são organizações com fins lucrativos. E funcionam em uma mecânica quase invisível, difícil de questionar, dirigindo-se "a nós com uma voz natural e transparente, sem qualquer referência à própria perspectiva tendenciosa" (Botton, 2015, p. 11). A imprensa, diz Mariani (2007), realiza uma espécie de catalogação do real, deixando-o simbolicamente disciplinado ao formular enunciados que estabilizam certos sentidos, sustentando-se no imaginário da transparência da linguagem e objetividade da notícia. "A criação dessa ilusão de 'unidade' do sentido é um recurso discursivo que fica evidente nos textos da mídia”, diz Gregolin (2007, p. 16), ao enfatizar que aquilo que "os textos da mídia oferecem não é a realidade, mas uma construção que permite ao leitor produzir formas simbólicas de representação da sua relação com a realidade concreta".

As empresas de comunicação fazem um esforço significativo para transmitir a ideia de isenção e equidade em suas atividades. Porém, toda instituição cuja finalidade é obter lucro age de acordo com seus próprios interesses. Não importa se o produto final oferecido ao consumidor é uma sandália (falaremos sobre o caso das havaianas logo adiante), um refrigerador, um automóvel, uma revista ou um pacote de viagens, um bem tangível ou intangível. As empresas de bens materiais ou imateriais devem se submeter ao jugo dos ambientes e das forças 
econômicas, sociais, políticas, culturais, demográficas ou naturais que condicionam a produção de algo para a obtenção de lucro.

Se a indústria da dieta e boa forma está centrada na exploração e no lucro, conforme alerta Foxcroft (2013), as publicações impressas e virtuais são a “boca desse mercado". Moraes (2003) observa que as corporações de mídia e entretenimento exercem um duplo papel estratégico nos dias atuais, e entender a interface entre eles é fundamental para compreender a força das organizações de mídia. Elas projetam-se ao mesmo tempo como agentes discursivos (o que podemos ver claramente em nosso trabalho de pesquisa), com uma proposta de coesão ideológica em torno da globalização, direcionando os sentidos sobre um assunto ou tema, e como agentes econômicos, vendendo produtos e intensificando a visibilidade de seus anunciantes (Moraes, 2003).

A nossa hipótese é a de que o discurso midiático contemporâneo das novas modalidades de regime (alicerçado nas tecnologias de informação, na velocidade e na repetição) enseja novas práticas culturais, o que afetaria a constituição do sujeito e sua relação com o corpo na contemporaneidade.

\subsubsection{O texto midiático das dietas e boa forma: a exploração (linguística e visual) do ser vivo}

Como dissemos anteriormente, cada período e cultura têm sua obsessão com uma forma corporal específica. Nos dias de hoje, pesquisadores como Maria Fernanda Laus (2013) apontam que a mídia pode ser a principal responsável pela propagação de um indicador de beleza hiperfísica e, muitas vezes, inatingível, ao estabelecer e divulgar ideais de forma física que enfatizam a extrema magreza para mulheres. É o que vamos mostrar nas análises e reflexões que se seguem. Na esteira do conceito de "texto da mídia" (Payer, 2015), a divulgação de um padrão de beleza inigualável de forma física está à cargo do que denominamos "texto midiático das dietas e boa forma", afetando diretamente a relação da mulher com o seu corpo na atualidade. Ao analisar os paradoxos e os contrates de que é feita a história do corpo no século XX e seguindo para o século XXI, Courtine (2008) levanta um importante questionamento:

Na hora em que se multiplicam os corpos virtuais, em que se aprofunda a exploração visual do ser vivo, em que se comerciam o sangue e os órgãos, em que se programa a reprodução da vida, em que se vai apagando a fronteira 
entre o mecânico e o orgânico mediante a multiplicação dos implantes, em que a genética se aproxima da replicação da individualidade, é mais que nunca necessário interrogar, experimentar o limite do humano: "Meu corpo será sempre meu corpo?” A história do corpo está apenas começando (p. 12).

Ao relacionar a insatisfação das mulheres com o próprio corpo, Deram (2014) faz um alerta: "Fique longe dos discursos das revistas, dos ambientes ou de pessoas que desvalorizam você” (p. 54). Pena que ficar longe do discurso e da ideologia divulgada pela mídia na sociedade atual é praticamente impossível, como veremos no decorrer deste trabalho. Segundo Payer (2005), a mídia é onipresente (seu poder alcança tanto a esfera pública quanto privada), no qual o público e o privado se entrelaçam narrativamente (Silverstone, 2005). Ela também é produtora de sentidos: um lugar privilegiado (por sua extensão massificante) para a manutenção de ideologias, ao estabelecer "uma relação imaginária entre o sujeito e suas condições de existência, uma relação simbólica que recai sobre seu principal - ou único - 'instrumento de produção’: o corpo" (Benedetti e Romão, 2007, s/p). Mais importante do que pensar na mídia é preciso refletir sobre a ambiência midiática (que falamos anteriormente), já que a mídia se estende para além do ponto de contato entre nós e seu discurso.

Para entender esse fenômeno midiático da boa forma, questionamos: Qual a relação do sujeito com o seu corpo na contemporaneidade? Com o advento do virtual, como nos relacionamos com nosso corpo? Ou ainda, ancorando-nos nas indagações de Orlandi (2012a, p. 87): Qual a relação do corpo com a ideologia? No nosso caso, qual a relação do corpo com a ideologia das dietas e da boa forma? A resposta para essas indagações assenta na relação entre a mídia e o corpo na contemporaneidade, intimamente atrelada a um processo de "construção do corpo". Neste processo de formatação corporal, "nos interessa o discurso produzido pela mídia e materializado em práticas sociais e condutas corporais” (Benedetti e Romão, 2007, s/p), como, por exemplo, o ato de emagrecer através das dietas sugeridas pela mídia. O corpo é o lugar no qual se inscrevem/escrevem leis sociais por meio de práticas e discursos. Ele é o resultado de um discurso social, cultural, histórico, político, econômico, medicinal, midiático. "Sendo a linguagem uma forma de ação e prática social, o corpo se faz meio e instrumento da linguagem, lugar no qual se organizam os significados sociais e culturais, lugar que explicita o discurso" (Benedetti e Romão, 2007, s/p).

Uma das especificidades da mídia na eficácia de interpelação dos sujeitos é que ela parece "não deixar espaços para além de si para nenhum outro discurso, para nenhuma outra forma de sujeito, para nenhum corpo que lhe sirva como suporte" (Payer, 2005, p. 19). 
Suspeitamos que o discurso midiático das novas dietas se legitima pela saturação que se dá pela repetição.

Se estamos diante de uma nova prática discursiva, diz Payer (2005), se estamos em outro real sócio-histórico, esse real também é impiedoso. No caso do mercado das novas dietas, Foxcroft (2013) é enfática: Gordura é "ruim" e fazer dieta é a norma, mas poucas pessoas nas últimas décadas tiveram o que poderíamos denominar uma relação "normal" com a comida, o fluxo incessante de informações sobre dietas, refeições rápidas e um ambiente alimentar radicalmente diverso do que existira há apenas uma geração anterior à nossa.

Segundo Payer (2005), é difícil nos esquivarmos dos efeitos dos enunciados do mercado (Payer, 2005), e isso tem implicações diretas nos processos de subjetivação do sujeito nos dias de hoje. Um levantamento feito pela Secretaria de Saúde do Governo do Estado de São Paulo com 50 pacientes entre 10 a 24 anos de idade, atendidas no ambulatório de Ginecologia do Hospital das Clínicas e do hospital estadual Pérola Byington, na cidade de São Paulo ${ }^{39}$, revelou que $85 \%$ acreditam que existe um padrão de beleza imposto pela sociedade, $46 \%$ acreditam que mulheres magras são mais felizes e 55\% delas adorariam simplesmente acordar magras. Diante desse cenário, $77 \%$ das jovens do Estado de São Paulo estão propensas a desenvolver algum tipo de distúrbio alimentar, como anorexia ou bulimia.

Como consequência do reforço dado pela mídia em mostrar corpos atraentes - alerta Laus et al (2013) - uma parcela da nossa sociedade se lança na busca de uma aparência física idealizada, determinado valores e normas que condicionam atitudes e comportamentos relacionados ao formato do corpo, sua aparência e seu peso.

\subsubsection{Afine com a berinjela: a linguagem publicitária nos discursos das dietas (corpo- imperativo-condicional)}

Antes de tecer algumas considerações sobre a linguagem publicitária, vou relembrar um episódio que ocorreu 2014, em um evento internacional de estudos discursivos. Na ocasião, apresentamos o trabalho $O$ discurso contemporâneo do novo e da novidade: memória, acúmulo e repetição, com questões embrionárias que foram sendo desenvolvidas no decorrer desta

\footnotetext{
${ }^{39}$ Recuperado em 13 de maio de 2016, de http://www.saopaulo.sp.gov.br/spnoticias/lenoticia.php?id=235488
} 
pesquisa. Ao término da apresentação oral, uma participante do evento fez várias considerações ao tema apresentado. Segundo a sua linha de raciocínio, os sentidos que circulam na mídia sobre o novo e a novidade e os sentidos que circulam na mídia em geral, em especial os produzidos pela publicidade e propaganda, nada mais são do que o reflexo da vontade do sujeito atual. Em suas observações, as agências de publicidade baseiam suas campanhas publicitárias em pesquisas que refletem a vontade do sujeito (seus gostos, idiossincrasias e desejos). Aquelas observações suscitaram uma série de reflexões sobre o poder da mídia, em especial na contemporaneidade.

Em parte, concordamos com suas observações. O sujeito é dotado de vontade. Deseja, reflete, opina, escolhe. Mas é um sujeito atravessado pela ideologia, pela história, pelo imaginário e inconsciente. As agências de publicidade fazem pesquisas para detectar aspectos relativos as vontades, carências, ambições e inseguranças do consumidor, mas não param por aí. O aparato midiático é, nos dias atuais, dotado de incrível capacidade técnica de manipular o imaginário simbólico para suscitar vontades e desejos voltados exclusivamente para o consumo.

Um caso clássico da publicidade brasileira que nos ajuda a explicitar nosso raciocínio é o da sandália havaianas. Até o início dos anos 1990, o produto era consumido principalmente pela base da pirâmide social. Portanto, um produto voltado para as classes menos favorecidas economicamente. Em 1994, uma estratégia publicitária deu início ao que, em publicidade, denomina-se "reposicionamento" da marca. Uma revista especializada no mercado publicitário conta como essa mudança de posicionamento da marca ocorreu ${ }^{40}$ :

A AlmapBBDO assumiu a conta, dando início a um casamento bem-sucedido que dura mais de duas décadas. "Fomos procurar as Havaianas dentro dos armários das celebridades. A base da pirâmide já usava as sandálias e buscamos a ponta, que tinha uma memória afetiva dos anos de 1960 e 1970. Partimos, então, para a relação aspiracional e criamos uma campanha com Luiz Fernando Guimarães mostrando personalidades como Malu Mader, Vera Fischer, Maurício Mattar e Bebeto com suas Havaianas", conta Marcello Serpa, sócio e co-presidente do board da AlmapBBDO. Este foi o primeiro passo para que a marca deixasse de ser commodity e criasse uma conexão emocional com o consumidor. "Passamos a abordar os valores intangíveis e a mostrar quem usa Havaianas", comenta Rui Porto. A partir de 1994, a mudança de posicionamento envolveu a diversificação de públicos com lançamentos de produtos para mulheres, homens e crianças. A moda passou a ser um pilar forte de atuação, com campanhas em revistas femininas. "Novos modelos de sandálias surgiram - femininos, masculinos, infantis - e fomos nos adaptando ao que estava ocorrendo. As campanhas de Havaianas são como uma novela, elas têm uma relação com o brasileiro. Era contraproducente

\footnotetext{
${ }^{40}$ Recuperado em 13 de maio de 2016, de http://marcas.meioemensagem.com.br/brands/cases/havaianas
} 
mudar", diz Serpa. [...] Os casais famosos também são personagens frequentes de campanhas. Leticia Spiller e Marcelo Novaes, por exemplo, estrelaram um filme em 1996. Recentemente, a atriz voltou ao ar em um comercial da marca, desta vez com o seu filho com Novaes, Pedro. Fernanda Tavares e Murilo Rosa também participaram de anúncios da marca. Atualmente, a campanha de Alpargatas, modelo fechado de Havaianas, traz dois casais do momento: Cléo Pires e Rômulo Arantes Neto e José Loreto e Débora Nascimento. A campanha - a primeira de Alpargatas - segue a linha da irreverência e brinca com a inversão de gêneros.

A mudança de posicionamento da marca (e todas as estratégias desenvolvidas pelos profissionais de comunicação para que os novos efeitos de sentido sobre as havaianas circulassem e aumentassem as vendas) expõem que o produto era consumido, até 1994, por um estrato social específico. Após a campanha publicitária, um outro grupo de consumidores (desta vez de classes mais altas) sentiu-se seduzida, autorizada e confortável a consumir, usar e exibir o produto. Esse grupo social provavelmente apresentava o desejo de consumir os chinelos havaianas, mas não o faziam por que o produto se destinava a outra esfera social, da qual a classe alta precisa distinguir-se.

Os bens de consumo são também um divisor de classes: diga qual marca ostentas (ou pretende ostentar) e direi a qual classe social você pertence (ou aparenta pertencer). Não se trata de uma regra, mas de um forte indicativo social. Mesmo que as classes sociais mais abastadas tinham um desejo intrínseco de consumir as sandálias havaianas, isso só ocorreu por uma ação midiática, que teve como objetivo alterar os vetores simbólicos de um objeto físico: antes um produto destinado "aos mais pobres", após ser mostrado como parte do universo das celebridades passou a ser, do mesmo modo, desejado por um público de maior renda. "A marca tem a clareza de quem é o seu consumidor e conseguiu aprender com ele. Ela sabe como interferir no hábito (de consumo) de maneira positiva", diz Rui Porto, consultor de comunicação da Alpargatas, ao acrescentar que os clientes compram, mais do que um simples produto, um estilo de vida ${ }^{41}$. Como mostraremos neste trabalho, não entendemos que essa faculdade da publicidade em intervir nas escolhas do sujeito seja algo positivo ou inofensivo. Há exemplos questionáveis de campanhas publicitárias voltadas para o público infantil, anúncios que usam corpos de modelos extremamente magros na divulgação de produtos de grandes marcas de vestuários. Além, é claro, do discurso publicitário das dietas, que promove um formato corporal inacessível e que pode estar subjacente ao crescimento de transtornos de imagem corporal, como anorexia e bulimia. É impossível negar a força da publicidade enquanto matriz criadora

\footnotetext{
${ }^{41}$ Recuperado em 13 de maio de 2016, de http://marcas.meioemensagem.com.br/brands/cases/havaianas
} 
de valores simbólicos, estéticos e sociais. Discursivamente, o discurso publicitário tem se mantido de modo a fazer circular certos efeitos de sentido sobre o mundo, fazendo-os parecer naturais e evidentes como se não houvessem outras formas de enunciá-lo.

O que pretendemos mostrar com esse exemplo é que não importa o produto, serviço, ideia ou conceito a ser transmitido: seja uma sandália ou uma suposta nova dieta, uma publicação mensal sobre boa forma ${ }^{42}$ ou um automóvel, no gesto de leitura que empreendemos sobre o aparato midiático seria reducionista ou até ingênuo acreditar que a mídia capte a vontade do sujeito e entregue, apenas, aquilo que ele já gostaria de consumir. Teríamos, assim, que descartar a capacidade das organizações de mídia em manipular o simbólico, construir identidades e influenciar subjetividades, suscitar desejos e atitudes de e para o consumo. Em nossa época, diz Gregolin (2007, p. 24), “a mídia é uma fonte poderosa e inesgotável de produção e reprodução de subjetividades, evidenciando sua sofisticada inserção na rede de discursos que modelam a história do presente".

O marketing tem sido definido ao longo da história como um conjunto de teorias e técnicas capazes de satisfazer os desejos e as necessidades dos consumidores. Um dos expoentes das teorias do marketing é o professor universitário americano Philip Kotler, considerado um dos maiores especialistas nas práticas do marketing e uma das pessoas mais influentes no mundo dos negócios. Ele é conhecido, especialmente no ensino do marketing e publicidade, pela sua obra Administração de Marketing, um best-seller do mundo corporativo. Em uma edição recente, os autores questionam:

O marketing cria ou satisfaz necessidades? De modo geral, o marketing vem sendo definido como algo que satisfaz os desejos e as necessidades dos clientes. Alguns críticos, contudo, sustentam que ele vai muito além disso e cria necessidades e desejos antes inexistentes. De acordo com esses opositores, os profissionais de marketing incentivam o consumidor a gastar mais dinheiro do que deveria em bens e serviços de que não precisa. [...] $\mathrm{O}$ marketing molda as necessidades e os desejos do consumidor? Ou o marketing simplesmente reflete as necessidades e os desejos do consumidor? (Kotler \& Keller, 2012, p. 27)

Ao empregar os termos "críticos" e "opositores", os autores sinalizam de forma óbvia qual a posição deles em relação ao tema. Diferentemente de Kotler e Keller, Benjamin Barber (2003) expõe sua indignação quando ouve os ativistas dos mercados defenderem a pretensa

\footnotetext{
42 Como veremos mais adiante no capítulo 3, quando empreendemos uma análise e reflexão sobre os nomes próprios das dietas, as publicações que compõem nosso corpus fazem parte da lógica do mercado, e seu funcionamento deve ser condizente com o sistema econômico vigente.
} 
autonomia dos consumidores: "Como se os gostos dos consumidores fossem criados partir do nada! Como se os desejos e as necessidades sobre as quais prosperam os mercados não fossem, eles mesmos, engendrados e moldados por estes mesmos mercados" (p. 50). Concordamos com Barber e tentaremos mostrar, no decorrer desta pesquisa, como o discurso midiático do mercado das novas dietas e boa forma vai muito além do que simplesmente atender as necessidades, anseios e desejos da mulher nos dias de hoje.

A publicidade como operadora de vetores simbólicos surge, segundo André Gorz (2005), com um sobrinho de Sigmund Freud, Edward Barnays, no início dos anos 1920. Ela passa a funcionar como um meio de produzir consumidores:

[A publicidade] funciona para produzir desejos e vontades de imagens de si e dos estilos de vida que, adotados e interiorizados pelos indivíduos, transformam-nos nessa nova espécie de consumidores que "não necessitam daquilo que desejam, e não desejam aquilo de que necessitam”. É a definição do consumidor [...] É às instâncias inconscientes, às motivações irracionais, aos fantasmas e aos desejos inconfessáveis das pessoas que era preciso apelar. Em vez de se dirigir, como se havia feito até então, ao senso prático dos compradores, a publicidade deveria conter uma mensagem que transforma os produtos, mesmos os mais triviais, em vetores de um sentido simbólico. Era preciso apelar às "condições irracionais", criar uma cultura do consumo, produzir o consumidor-tipo que procura e encontra, no consumo, um meio de exprimir seu innermost self (seu "eu mais íntimo") (Gorz, 2005, p. 48).

A propaganda ${ }^{43}$ (o que também pode ser empregado para a publicidade e todo processo de marketing) e suas práticas estão ancoradas em uma "bio-psicologia" alicerçadas em três teses:

1 - [a primeira tese é que] a natureza humana é constituída de pulsões, sendo que as duas principais, instaladas em todo indivíduo, são:

- a pulsar alimentar, econômica, lógica [...];

- a pulsão afetiva, agressiva, combativa [...];

2 - a segunda é que o processo objetivo dessas pulsões, seu jogo no cerne da natureza humana, pode, desde que é conhecido pela ciência moderna, ser controlado, instrumentalizado e colocado a serviço de qualquer política: as "técnicas de propaganda" são armas, como o canhão de 75, a grande Bertha, o carro de Patton ou a máquina de Guerra de Stalin (...);

3 - a terceira tese é que esta guerra metafórica engaja o destino de milhões de homens e mulheres que, segundo a estratégia de uma "campanha de propaganda", farão balançar este ou aquele lado, tomarão este ou aquele caminho, seguirão esta ou aquela direção (Pêcheux, 2011, pp. 78-79).

\footnotetext{
${ }^{43}$ No jargão publicitário brasileiro, a publicidade pode ser entendida como técnica de comunicação destinada a fornecer informações sobre produtos ou serviços com fins comerciais, enquanto a publicidade é voltada para a divulgação de ideias; daí a expressão "propaganda política" e não "publicidade política". Por isso entendemos que Pêcheux estava referindo-se tanto à publicidade quanto à propaganda.
} 
As três teses de Pêcheux incidem sobre a partilha do racional e do irracional do sujeito, formando um corpo teórico profundamente instalado nas evidências de nosso tempo. O que nos interessa aqui é que esse conjunto de mecanismos que operam nas instâncias irracionais do sujeito, como disse Barnays, e que é corroborado por Pêcheux na bio-psicologia da propaganda, criaram as condições técnicas-discursivas de assujeitamento político e ideológico. Enquanto a antiga economia de bens materiais visava ao corpo, observa Barber (2003, p. 51), a nova economia dos serviços imateriais toma como alvo a cabeça e o espírito.

Diz Pêcheux (2011, p. 87) que, após a Segunda Guerra Mundial, uma nova articulação se instituía entre o "racional" e o "irracional", entre a objetividade dos fatos e a subjetividade das experiências. É exatamente isso que pretendemos explicitar neste trabalho de pesquisa: a subjetividade, reporta Gregolin (2007), “está em circulação, é essencialmente social, assumida e vivida por indivíduos em suas existências particulares" (p. 21), e a mídia, ao colocar em circulação enunciados que regulamentam as formas de ser e agir, como o discurso midiático das novas dietas, realiza "um agenciamento coletivo de enunciação, entrecruzando determinações coletivas sociais, econômicas, tecnológicas etc.” (p. 21). Como veremos no capítulo 5 (Expandir para lucrar: a metáfora do elástico), a saturação dos mercados tradicionais e a superprodução de bens fez com que o capitalismo sirva não apenas às necessidades reais dos consumidores. Os interesses do consumidor do século XXI não são exclusivamente inerentes à sua vontade, mas igualmente "criadas pela promoção, pelo condicionamento, pela publicidade, pela persuasão cultural” (Barber, 2003, p. 51).

Se entendemos que a ambiência midiática é um espaço privilegiado de circulação de objetos de saber (conhecimento), a mídia atua "como lugar ideológico de representação dos padrões sociais sobre os saberes constituídos" (Medeiros, 2008, p. 52). Como ferramenta midiática, a publicidade opera discursivamente invadindo todos os espaços e criando discursos que miram os sentimentos, desejos, motivações, afetando o imaginário e a subjetividade. "A mídia leva essa operação a seu nível exponencial, fornecendo verdadeiras próteses de identidade, 'identidades prêt-à-porter', conclui Gregolin (2007, p. 21).

Ao fazer parte do mundo da comunicação, portanto, da mídia, e ter papel crucial na formação e circulação dos sentidos que transitam na/através da ambiência midiática, podemos afirmar que a publicidade atua como "aparato ideológico do sistema" (Ramonet, 2003, pp. 243244). Daí a necessidade de mobilizarmos o conceito de ideologia, que orienta a produção do saber (no nosso caso, um saber sobre as novas dietas e a boa forma), e interpela o sujeito a todo 
momento e em todo lugar, estabelecendo o que deve ou não ser aceito (Medeiros, 2008), ou, no caso midiático, o que pode ou não ser veiculado.

Tomemos como exemplo o corpo: a objetividade nos coloca diante de uma estrutura física individual, em que pesam diversas características singulares como fatores genéticos, ambientais, culturais e de estilos de vida; podemos estar acima do peso inclusive por alterações biológicas. Em suma, o formato do nosso corpo pode estar aquém da nossa capacidade de emagrecer e não depende exclusivamente de nossa vontade em seguir a dieta da moda. Já o aparato midiático faz circular um discurso sobre dietas fundamentado na subjetividade das experiências com o corpo, e não na objetividade dos fatos. Na publicidade das dietas, as condições técnicas-discursivas a que se referem Pêcheux podem ser imagens retocadas de corpos artificiais ou textos milimetricamente estruturados para convencer o sujeito de que aquilo que está sendo veiculado deve ser prontamente interiorizado. Esse discurso ideológico interpela o sujeito a emagrecer com a mais nova dieta, a consumir o alimento da moda, a praticar o exercício das celebridades. O discurso publicitário das dietas e do corpo perfeito mascara a realidade dos fatos e distorce a banalidade da vida comum.

Essa análise também é feita por Dênis de Moraes (2003), ao enfatizar que a mídia e suas corporações exercem papéis estratégicos na contemporaneidade:

O primeiro diz respeito à sua condição peculiar de agentes operacionais da globalização, do ponto de vista da enunciação discursiva. Não apenas legitimam o ideário global, como também o transformam no discurso social hegemônico, propagando visões de mundo e modos de vida que transferem para o mercado a regulação das demandas coletivas. A retórica da globalização intenta incutir a convicção de que a fonte primeira de expressão cultural se mede pelo nível de consumo dos indivíduos (p. 187).

As revistas de boa forma e vida saudável atuam no contexto midiático legitimando um ideário sobre o corpo-projeto e como fazer para alcançá-lo. É difícil caracterizar as revistas e sites de boa forma quanto ao seu conteúdo. Os textos e as imagens das revistas e seus pares virtuais (blogs, sites, redes sociais, entre outros) nos levam a crer que estamos diante de um discurso jornalístico que faz funcionar os sentidos de beleza, perfeição, magreza, atitude, vitalidade, jovialidade, entre tantos outros associados ao corpo-projeto. O deslizamento dos efeitos de sentidos provocados por essas revistas permite, nas arestas dos discursos, entrever o seu teor publicitário, uma publicidade travestida de jornalismo.

Uma das características da linguagem publicitária é o verbo no imperativo. Faça, compre, emagreça. Vejamos alguns exemplos de textos que circulam em nosso corpus e abusam de recursos claramente publicitários: 


\section{Recorte 3 (grifos nossos):}

Afine com a berinjela - cardápio de fim de semana diminui $2 \mathrm{~cm}$ na cintura ${ }^{44}$ Apaixone-se pela corrida - a gente ensina ${ }^{45}$

Perca 5 centímetros de cintura com nosso cardápio ${ }^{46}$

Copie o prato das mulheres mais magras do mundo ${ }^{47}$

Realize seus desejos! Como usar o aparelho mais power da academia para emagrecer e definir ${ }^{48}$

Conquiste sua barriga chapada ${ }^{49}$

O uso do imperativo na linguagem publicitária tem como objetivo produzir efeitos de certeza, evidência, convicção. Essas formulações no imperativo indicam ordens ao sujeito que deve obedecê-las, segui-las cegamente, sendo conduzido por aquilo que o discurso midiático propõe como efeito de verdade. Aquilo que está sendo dito deve ser entendido tal qual a publicação propõe. No decorrer de nosso percurso, a análise dos enunciados traz à tona o que Payer (2005, p. 12) chamou de "performance de linguagem", a articulação de palavras com o intuito de convencer o interlocutor "através da produção de evidência dos sentidos". O objetivo dos redatores é não deixar margem para o consumidor/leitor duvidar daquela informação. Daí a diferença entre enunciados teoricamente jornalísticos ou publicitários. Concordamos com a perspectiva de Ramonet (2003) ao defender que, como consequência da revolução digital, passou a ser extremamente difícil, tanto intelectual quanto objetivamente, estabelecer distinções nítidas entre o mundo da mídia, o mundo da comunicação, o mundo da cultura de massas e o mundo da publicidade. Mas tentaremos estabelecer algumas particularidades observando os títulos das reportagens abaixo:

\section{Recorte 4 (grifos nossos):}

Tomate pode ajudar a preservar pulmão de ex-fumante e $^{50}$

Bruna Marquezine explica corpo mais magro e conta sobre problema na tireoide $^{51}$

\footnotetext{
${ }^{44}$ Chamada de capa da revista Corpo a Corpo (edição n. 306).

${ }^{45}$ Chamada de capa da revista Boa Forma (edição n. 340).

${ }^{46}$ Chamada de capa da revista Boa Forma (edição n. 342).

${ }^{47}$ Chamada de capa da revista Corpo a Corpo (edição n. 315).

${ }^{48}$ Chamada de capa da revista Boa Forma (edição n. 350).

${ }^{49}$ Chamada de capa da revista Womne's Health (edição n. 86).

${ }^{50}$ Recuperado em 18 de janeiro de 2017, de http://www1.folha.uol.com.br/equilibrioesaude/2017/12/1946253tomate-pode-ajudar-a-preservar-pulmao-de-ex-fumante.shtml

51 Recuperado em 18 de janeiro de 2017, de https://f5.folha.uol.com.br/celebridades/2018/01/brunamarquezine-explica-magreza-excessiva-e-conta-sobre-problema-na-tireoide.shtml
} 
As 5 dietas dos famosos que você deve evitar em 2018, segundo especialistas em nutrição ${ }^{52}$

Estudo mostra que dieta mediterrânea pode tratar a depressão ${ }^{53}$

Em sua maioria, os títulos jornalísticos empregados em reportagens de cunho noticioso contêm verbo na voz ativa, estão no tempo presente e não usam pontuação (ponto, dois pontos, ponto de interrogação, exclamação, reticências, travessão ou parênteses). Já para os artigos assinados pelos colunistas são permitidas outras construções linguísticas. Segundo o manual de redação de um jornal brasileiro (2007), os títulos devem ser capazes de tornar claro, em poucas palavras e em ordem lógica, o objeto da notícia, ao mesmo tempo que atraem o leitor e incitam seu interesse. Há ainda um cuidado do fazer jornalístico para não impor uma determinada conduta, ao explorar recursos linguísticos como "Tomate pode ajudar" ou "dieta mediterrânea pode tratar". O verbo no interativo ordena que o interlocutor realiza uma ação, expressando o que quer que ele fação por meio de uma ordem, pedido ou exortação.

Os enunciados acima reverberam sentidos de um corpo que necessita de tempo, investimento e esforço do sujeito para obtê-lo (conquiste sua barriga chapada!). O sujeito é interpelado pela ideologia do mercado e convocado a "realizar seus desejos" na busca do corpoperfeito. No entanto, como veremos nos próximos itens, o corpo-perfeito demanda condições financeiras e tempo em academias, procedimentos estéticos e toda uma gama de recursos remotos à imensa maioria dos sujeitos. Há ainda o fator "alcance o sucesso", como veremos ainda neste capítulo. E lembremos sempre: enquanto discurso (textos e imagens adulteradas eletronicamente), o corpo-perfeito (corpo-imagem) não é análogo ao corpo da realidade, simplesmente porque ele não existe enquanto organismo vivo.

\subsubsection{Nome próprio: efeitos de potência, facilidade, eficiência, rapidez}

Quem nunca se deparou com uma revista, livro, blog, site, alguém do nosso convívio próximo ou alguma personalidade pronunciando o nome de algum tipo de dieta para emagrecer. Em um artigo publicado em uma revista semanal de grande circulação no país, "uma das

\footnotetext{
${ }^{52}$ Recuperado em 18 de janeiro de 2017, de http://www1.folha.uol.com.br/equilibrioesaude/2018/01/1947459as-5-dietas-dos-famosos-que-voce-deve-evitar-em-2018-segundo-especialistas-em-nutricao-shtml

${ }^{53}$ Recuperado em 18 de janeiro de 2017, de https://oglobo.globo.com/sociedade/saude/estudo-mostra-quedieta-mediterranea-pode-tratar-depressao-22181779\#ixzz54Y8qwdcLstest
} 
grandes ambições da humanidade é achar uma panaceia universal, uma fórmula capaz de combater todos os males que afligem nosso corpo" ${ }^{" 54}$. O texto cita algumas das promessas para emagrecer que surgiram nos últimos cem anos: "Dieta Master Cleanse" (1940), "Dieta Atkins" (1972), “Dieta da Princesa” (1975), “Dieta Ornish” (1990), “Dieta do Tipo Sanguíneo” (1996) e "Dieta da Banana Matinal" (2008). Menos de um mês depois, outra revista publicou uma matéria de capa: "A Dieta Paleolítica" 55 . Os nomes das dietas que aparecem no quadro abaixo foram sendo colecionados durante a pesquisa, incialmente de forma despretensiosa, apenas como exercício de observação. Com o decorrer do trabalho, eles se mostraram uma importante fonte para entendermos alguns dos efeitos de sentidos gerados por essa linguagem, que é renovada incessantemente pelas publicações de dietas e boa forma. Selecionamos somente aqueles que foram publicados na mídia; as dietas que chegaram ao nosso conhecimento e não foram passíveis de verificação ou não apareceram publicadas em nenhum canal midiático foram descartadas.

Ao circularem na ambiência midiática dos regimes de emagrecimento e boa forma, essas designações fazem ressoar efeitos de sentidos que permeiam não somente o nome de cada uma, mas os enunciados de uma forma geral. Lembrando que tanto os enunciados quanto as imagens são trabalhados pelos editores/jornalistas/publicitários/redatores/fotógrafos para direcionar cirurgicamente os sentidos. $\mathrm{O}$ antropônimo das dietas é assinalado propositalmente de modo a personificar a nova modalidade de emagrecimento, conferindo-lhe um sentido apurado e distinto. Provavelmente, esse efeito não seria marcado apenas com emprego do substantivo feminino dieta. É importante frisarmos que estamos considerando a palavra dieta em nosso corpus de análise, dentro de um fenômeno complexo que abrange uma série de questões. Portanto, não é possível observá-la de forma estanque, mas atuando em conjunto com os enunciados, as imagens, o contexto sócio-histórico, político, econômico e cultural, atrelada ao formato do corpo que circula na ambiência midiática das novas dietas e boa forma. Ressaltamos que os nomes das dietas aparecem em recortes anteriores e posteriores. Se a análise que aqui empreendemos ocorre em um determinado momento, isso se faz apenas como estratégia metodológica e de análise.

\footnotetext{
${ }^{54}$ Recuperado em 8 de fevereiro de 2014, de http://veja.abril.com.br/noticia/saude/dietas-na-corda-bamba

55 Recuperado em 10 de fevereiro de 2014, de http://epoca.globo.com/vida/vida-util/saude-e-bemestar/noticia/2014/02/dieta-bpaleoliticab.html. Tanto as revistas Veja quanto Época são consideradas publicações de informação e opinião gerais, e não voltadas apenas para o segmento "bem estar" ou "boa forma". Ainda assim, ambas têm publicado com frequência reportagens relacionadas às dietas. As duas matérias acima são exemplos dessa pauta jornalística: a revista Veja publicou o texto sobre as dietas em 18/01/2014, e menos de um mês depois (07/02/2014) Época estampou em sua capa a reportagem "A Dieta Paleolítica".
} 
Dieta alcalina;

Dieta Atkins;

Dieta Clean;

Dieta da argila;

Dieta da banana;

Dieta da banana matinal;

Dieta da batata doce;

Dieta da berinjela;

Dieta da berinjela turbinada;

Dieta da cabala;

Dieta da caloria negativa;

Dieta da castanha-dopará;

Dieta cetogênica;

Dieta da chia;

Dieta chinesa;

Dieta da fibra verde;

Dieta da hora;

Dieta da idade verdadeira;

Dieta da juventude;

Dieta da lua;

Dieta da papinha de bebê;

Dieta da pílula;

Dieta da placenta;

Dieta da princesa;

Dieta da proteína;

Dieta da sopa;

Dieta da tapioca;

Dieta da USP;

Dieta das castanhas;

Dieta das sementes;

Dieta das 5 superproteínas;

Dieta das 8 horas;

Dieta de emergência;

Dieta de 1000 calorias;

Dieta de 900 calorias;
Dieta de baixo consumo de carboidratos;

Dieta de Beverly Hills;

Dieta de fim de ano;

Dieta definitiva de Beck;

Dieta de South Beach;

Dieta Decrescente -

Crescente (DC);

Dieta definitiva de Beck;

Dieta derrete-gordura;

Dieta desintoxicante;

Dieta detox;

Dieta dissociada;

Dieta do açaí;

Dieta do atum;

Dieta do baixo índice glicêmico;

Dieta do carboidrato;

Dieta do carvão;

Dieta do chá matcha;

Dieta do cortisol;

Dieta do equilíbrio;

Dieta do freekeh;

Dieta do futuro;

Dieta do GH;

Dieta do índio;

Dieta do mediterrâneo;

Dieta do mel;

Dieta do metabolismo rápido;

Dieta do miojo milagroso;

Dieta do ovo;

Dieta do sanduba;

Dieta do tipo sanguíneo;

Dieta dos 17 dias;

Dieta dos 30 minutos;

Dieta dos cabelos;

Dieta dos carboidratos balanceados;

Dieta dos casais;

Dieta dos nutrientes;
Dieta dos passos;

Dieta dos pontos;

Dieta dos shakes;

Dieta dos vigilantes do peso;

Dieta Dukan;

Dieta em circuito;

Dieta fracionada;

Dieta francesa;

Dieta friendly;

Dieta funcional;

Dieta ideal;

Dieta low carb;

Dieta Master Cleanse;

Dieta meta real;

Dieta metabólica;

Dieta noturna do tomate;

Dieta orgânica;

Dieta Ornish;

Dieta ortomolecular;

Dieta para antes e depois do parto;

Dieta para emagrecer;

Dieta para regular e acalmar o intestino;

Dieta parisiense;

Dieta Pegan;

Dieta pós-festas ou desintoxicante;

Dieta pró-músculos;

Dieta que blinda o cérebro;

Dieta Ravenna;

Dieta sem glúten;

Dieta sugar free;

Dieta vegetariana;

Dieta volumétrica;

Dietoterapia;

Não-Dieta;

Mind diet. 
As adjetivações remetem a efeitos de singularidade, como se aquela dieta específica possuísse todos as qualidades necessárias para funcionar e fazer emagrecer de forma rápida. Sobre a marca "dieta", anotamos que a denominação está sempre ligada ao funcionamento de um nome próprio que, como por efeito de autoridade, atribui imaginariamente importância e legitimidade ao programa de emagrecimento. Também observamos a partícula "de" acrescida de certo artigo definido, ou seja, "das castanhas", "da proteína”, "da sopa”, o que marca um alimento ou receita que seria capaz de assegurar o emagrecimento e se tornaria de saída a solução para o problema do peso. São atributos que dão às dietas efeitos de superpoderes, algo mágico, intenso e poderoso. E isso se faz em um recorte de tempo, que é a data da publicação: naquele determinado momento, o da publicação de um conteúdo em uma revista impressa ou site, a dieta surge com poderes capazes de suplantar todas as ideias anteriores para emagrecer.

A presunção dos editores não tem limites. Recordamos que tudo isso ocorre sob a égide do capitalismo, e as publicações impressas ou virtuais são produtos midiáticos com fins econômicos. A edição de uma revista de dieta e boa forma deve chegar aos seus assinantes e alcançar boas vendagens em bancas de jornais, livrarias ou mercados. E devem fazer circular todos os produtos e serviços dos anunciantes que compraram espaços publicitários na revista ou site para que os consumidores conheçam e comprem aquilo que está sendo anunciado. Tudo funciona em uma engrenagem para obtenção de lucro.

Para pensarmos os efeitos de sentidos dos nomes atribuídos às dietas, vamos empreender uma análise de alguns nomes, agrupando-os ou analisando-os separadamente. Um dos grupos é composto pelas dietas formuladas por médicos ou profissionais da saúde que alcançaram o status de celebridade. Esses profissionais fazem parte de um grupo de "especialistas midiáticos", credenciados pela mídia a comentar, elucidar ou opinar sobre determinado tema por força do reconhecimento profissional ou sucesso na mídia. Não faltam exemplos desses profissionais nas mais diversas áreas. Essa é uma das premissas da sociedade midiatizada: não basta ser um excelente profissional, é preciso aparentar e aparecer (na mídia, claro!).

Algumas das mais famosas dietas do grupo dos especialistas midiáticos são: Dieta Dukan (médico argelino Pierre Dukan), Dieta Atkins (Robert Coleman Atkins, médico e cardiologista americano) e Dieta definitiva de Beck (psicóloga americana). Vamos nos ater a duas delas: Dukan e Atkins. Provavelmente o caso mais famoso é também o mais controverso. Pierre Dukan já vendeu milhões de livros em todo o mundo, mas sua dieta recebe inúmeras críticas, como a de causar danos à saúde quando mantida no longo prazo. A Agence Nationale de Sécurité Sanitaire de l'Alimentation, de l'Environnement et du Travail (Anses), órgão que funciona como uma agência de segurança alimentícia francesa, tachou o regime de Dukan de 
“desequilibrado", enquanto a Agencia Española de Consumo, Seguridad Alimentaria y Nutrición (Aecosan) incluiu a Dieta Dukan em uma lista negra junto com outras dietas tidas como milagrosas (Sahuquillo, 2012).

Assim como o universo das dietas está atrelado às condições de produção desse mesmo discurso, sendo um dos fatores principais a tecnologia, da mesma forma o império construído por Dukan está centrado em seu site. No Brasil, o site (www.dietadukan.com.br) convoca o sujeito a praticar a Dieta Online (Dieta agora é online!). Ao comprar o pacote de emagrecimento, o sujeito receberá diariamente instruções de como emagrecer seguindo os passos criados por Dukan. Robert Atkins foi, segundo Foxcroft (2013, p. 239), "mais um guru de uma longa linhagem: uma pessoa que descobriu um regime, experimentou-o em si mesmo, aparentemente teve sucesso e passou a vende-lo para outros". Atkins alavancou sua dieta por intermédio da mídia:

Em 1965, Atkins apareceu no programa de TV Tonight, e um artigo sobre ele e seu regime foi publicado na revista Vogue, em 1970 (durante algum tempo, sua dieta foi conhecida como "dieta Vogue"). [...] No auge da popularidade da sua dieta, em 2003 e 2004, estimava-se que um em cada onze americanos a adotasse. Ela é propagandeada como "o plano de redução sem fome, luxuoso, que realmente funciona" e é o que se conhece como dieta cetogênica (Foxcroft, 2013, p.238).

O discurso do novo e da novidade, que abordaremos no capítulo 4, não é recente. Em 1972, Atkins lançou o livro Dr. Atkins' Revolution Diet, que vendeu milhões de exemplares. Vinte anos depois, lançou Dr. Atkins' New Revolution Diet. Gurus das dietas aparecem constantemente há quase 200 anos vendendo regimes e alimentos especiais, alerta Foxcroft. As dietas associadas a um profissional renomado sugere ao leitor efeitos de que as instruções para emagrecer provêm de uma fonte fidedigna, de estudos e práticas clínicas validadas por especialistas experientes. São efeitos de sentidos que evidenciam uma certa dose de credibilidade advinda de uma espécie de "autoridade adicional", um "conhecimento especializado" (Foxcroft, 2013, p. 238), já que seus criadores são médicos e teriam, portanto, o conhecimento necessário para elaborá-las.

Outro grupo é formado pelas dietas atreladas a um ou mais alimentos (açaí, atum, banana matinal, banana, batata doce, berinjela turbinada, berinjela, castanha-do-pará, chia, mel, miojo milagroso, ovo, sanduba, sementes, entre tantas outras). As dietas atreladas aos alimentos sugerem que a ingestão de um deles pode emagrecer rapidamente. São efeitos de sentidos que 
atribuem a determinados alimentos, em certas épocas, aptidão para reduzir o peso de quem os ingere. Vamos destacar três dessas dietas que circulam em nosso corpus:

Recorte 5:

GANHE MAIS MÚSCULOS COM A DIETA DO OVO. É fácil e ainda emagrece $^{56}$

DIETA DA BATATA-DOCE. Você vai ganhar mais músculos ${ }^{57}$

DIETA DAS ERVAS FUNCIONAIS. Seca e desincha $8 \mathrm{~kg}$ em 30 dias $^{58}$

$-3 \mathrm{KG}$ por semana! com a dieta da SOPA DETOX ${ }^{59}$

O recorte acima fornece pistas que mostram a regularidade com que certos enunciados são elaborados e circulam na mídia, tendo como base os mesmos recursos linguísticos de outros enunciados, em um trabalho contínuo de repetição, estabilizando os dizeres e direcionando os sentidos sobre dietas. Acima, as chamadas de capa das dietas do ovo, batata-doce e ervas funcionais fazem ressoar efeitos de facilidade e rapidez, como se a ingestão desses produtos pudesse proporcionar ganho muscular e facilitar o emagrecimento de forma rápida e prática. Abaixo, observamos como cada publicação desenvolveu os enunciados sobre essas dietas:

\section{Recorte 6:}

Nem carrne nem whey protein: o grande aliado dessa dieta é o ovo. A BF mostra como incluir esse alimento no dia a dia de um jeito gostoso e eficiente para os músculos. Você ainda vai ficar magra (sim, dá para enxugar gordurinhas) e definida! ${ }^{10}$

I LOVE BATATA-DOCE. O carboidrato dos músculos. Ela é perfeita para quem quer ganhar músculos. Saiba o jeito certo de incluí-la no cardápio e conquiste um corpo firme e definido! ${ }^{61}$

ERVAS QUE AFINAM. Para mandar embora até 4 quilos em apenas 15 dias, aposte nessas benfeitorias tanto no preparo do arroz quanto na hora de fazer o chá da tarde ${ }^{62}$

Dieta da SOPA. Afine $3 \mathrm{~kg}$ por semana! Acabar com o excesso de peso parece ser uma missão quase impossível. Mas não para esta dieta que promete secar de 3 a $7 \mathrm{~kg}$ em uma semana. Sim, você leu certo! Pronta para conhecê-la? ${ }^{63}$

\footnotetext{
${ }^{56}$ Chamada de capa da revista Boa Forma (edição n. 346).

${ }^{57}$ Chamada de capa da revista Boa Forma (edição n. 342).

${ }^{58}$ Chamada de capa da revista Corpo a Corpo (edição n. 306).

${ }^{59}$ Chamada de capa da revista Shape (edição n. 69)

${ }^{60}$ Matéria da revista Boa Forma (edição n. 346, p. 60).

${ }^{61}$ Matéria da revista Boa Forma (edição n. 342, p. 41).

${ }^{62}$ Matéria da revista Corpo a Corpo (edição n. 306, p. 74).

${ }^{63}$ Chamada de capa da revista Shape (edição n. 69, p. 64)
} 
Em um primeiro momento, as publicações convocam o leitor a ganhar músculos e perder peso rapidamente, usando sempre o imperativo da velocidade. Perca peso e ganhe músculos, mas em pouco tempo e sem muito esforço. Os efeitos de sentidos estão atrelados às condições de existência da mulher na atualidade. A perda dos quilos tem que acompanhar e funcionar atrelada ao efeito de velocidade (falaremos disso mais adiante e mais precisamente no capítulo 5). Outros efeitos característicos do discurso das dietas e boa forma estão igualmente presentes, como secar, afinar, definir, conquistar os atributos do corpo-projeto, firme e definido.

Os alimentos acima, quando consumidos com moderação e de forma balanceada com outros alimentos, são importantes para o bom funcionamento do organismo. Isso é fato. O que questionamos é a forma como essa linguagem é trabalhada, recortada de modo a conferir ao consumo de um tipo de alimento tantos benefícios (estéticos) em tão curto espaço de tempo. É como se os efeitos de sentidos das dietas do ovo, batata-doce e ervas funcionais, entre tantas outras dietas que surgem a cada nova publicação, atribuíssem a esses alimentos virtudes mágicas, fazendo-os funcionar no imaginário como um elixir do corpo-perfeito.

Antes de falarmos sobre outros nomes de dietas, façamos um exercício comparativo para mostrar como a linguagem desse discurso é trabalhada de forma repetida, usando os mesmos recursos (que na nossa visão são técnicas publicitárias) para falar de praticamente tudo que envolve esse universo. Expliquemos: seja para falar da dieta da sopa (ou de qualquer outro alimento) ou para contar a história de superação de uma celebridade que emagreceu após a gravidez e está mais linda do que nunca (trataremos esse tópico mais para frente), o enredo é praticamente o mesmo:

\begin{abstract}
Recorte 7:
Dieta da SOPA. Afine $3 \mathrm{~kg}$ por semana! Acabar com o excesso de peso parece ser uma missão quase impossível. Mas não para esta dieta que promete secar de 3 a $7 \mathrm{~kg}$ em uma semana. Sim, você leu certo! Pronta para conhecê-la?

Nesse corpão, agora habitam a Ana mulher, a profissional e a mãe. Ela lembra que, depois de ter ganhado 30 quilos na gravidez, o quadril foi o primeiro a voltar à medida anterior [...]. A batalha foi grande, mas em sete meses ela já pesava 69 quilos de novo. Como chegou lá? Vem descobrir.
\end{abstract}

A homogeneização é um dos princípios dos discursos das dietas. O enredo é construído mostrando os quilos que podem (ou foram) perdidos por uma celebridade ou pela ingestão de um alimento que constitui a base de uma nova dieta. Os números fazem parte de uma estratégia para quantificar a perda: o objetivo é diminuir, enxugar, afinar. Eles indicam efeitos de sentidos que apontam para uma única direção: o emagrecimento. Se o sujeito-leitor é convidado a 
experimentar a Dieta da Sopa e emagrecer entre 3 e 7 quilos em uma única semana, através do deslizamento dos sentidos é possível aplicar os mesmos efeitos ao corpo antes e após a gravidez, que engordou 30 quilos e, também de forma veloz (em apenas sete meses), retornou ao peso anterior à gestação (69 quilos).

Ao agrupar algumas dietas que circulam em nosso corpus em diferentes épocas e publicações, é possível visualizar a repetição estabilizadora desse discurso, dizeres que geram efeitos de sentidos pela insistência e exaustão com que circulam e promovem valores sobre o corpo da mulher. Não se trata de uma análise de conteúdo, muito pelo contrário. Após quatro anos debruçados sobre esse corpus, muitas vezes não percebemos o quanto os textos se repetem, em uma regularidade enunciativa nauseante. O que pretendemos mostrar é a corrupção simbólica promovida pelos criadores das novas dietas, materializando diferentes recortes de diferentes épocas e publicações em um quadro cronológico/linguístico/enunciativo:

\begin{tabular}{|c|c|c|c|c|}
\hline $\begin{array}{c}\text { Data da } \\
\text { publicação }\end{array}$ & Publicação & Nome da dieta & $\begin{array}{c}\text { Enunciado } \\
\text { instigante/convocatório }\end{array}$ & $\begin{array}{l}\text { Promessas } \\
\text { atribuídas à } \\
\text { dieta }\end{array}$ \\
\hline $\begin{array}{l}\text { agosto/ } \\
2014\end{array}$ & $\begin{array}{l}\text { Corpo a } \\
\text { Corpo }\end{array}$ & $\begin{array}{l}\text { Dieta Dash } \\
\text { (Dietary } \\
\text { Approaches to } \\
\text { Stop } \\
\text { Hypertension) }\end{array}$ & $\begin{array}{l}\text { Siga os princípios da dieta } \\
\text { que ocupa o primeiro lugar } \\
\text { entre os métodos mais } \\
\text { eficazes de emagrecimento }\end{array}$ & $\begin{array}{l}\text { Elimine } 5 \text { quilos } \\
\text { em um mês sem } \\
\text { perceber }\end{array}$ \\
\hline $\begin{array}{c}\text { fevereiro/ } \\
2015\end{array}$ & Boa Forma & Dieta Clean & $\begin{array}{l}\text { Você perde peso e ganha } \\
\text { pique! }\end{array}$ & $-5 \mathrm{~kg}$ em 21 dias \\
\hline $\begin{array}{c}\operatorname{março/} \\
2015\end{array}$ & Boa Forma & $\begin{array}{l}\text { Dieta do } \\
\text { Metabolismo } \\
\text { Rápido }\end{array}$ & $\begin{array}{l}\text { Então, bora lá incinerar as } \\
\text { gordurinhas? }\end{array}$ & $\begin{array}{l}\text { Funciona como } \\
\text { palha seca na } \\
\text { fogueira: queima } \\
\text { até } 10 \text { quilos em } \\
28 \text { dias! }\end{array}$ \\
\hline $\begin{array}{c}\operatorname{marcço} / \\
2015\end{array}$ & Shape & Dieta Ravenna & $\begin{array}{l}\text { Descobrimos todos os } \\
\text { segredos desse método de } \\
\text { sucesso para você afinar } \\
\text { também. Vem com a gente! }\end{array}$ & $\begin{array}{l}\text { A SHAPE } \\
\text { conversou com } \\
\text { duas leitoras que } \\
\text { detonaram mais } \\
\text { de } 30 \mathrm{~kg} \text { com o } \\
\text { método. Elas } \\
\text { contam tudo! }\end{array}$ \\
\hline $\begin{array}{c}\operatorname{março/} \\
2015\end{array}$ & Dieta Já! & $\begin{array}{l}\text { Dieta das } 5 \\
\text { Superproteínas }\end{array}$ & $\begin{array}{l}\text { Saiba como fazer um } \\
\text { programa alimentar baseado } \\
\text { nas proteínas }\end{array}$ & $\begin{array}{l}\text { Enxugue até } 4 \mathrm{~kg} \\
\text { em um mês }\end{array}$ \\
\hline
\end{tabular}




\begin{tabular}{|c|c|c|c|c|}
\hline $\begin{array}{l}\text { abril/ } \\
2015\end{array}$ & Dieta Já! & $\begin{array}{l}\text { Dieta para } \\
\text { hipertensas }\end{array}$ & $\begin{array}{l}\text { Separamos um plano } \\
\text { alimentar exclusivo para } \\
\text { você controlar a hipertensão } \\
\text { [...] } \\
\text { Quer conhecer mais do } \\
\text { cardápio exclusivo para } \\
\text { hipertensos da Dieta Jál? } \\
\text { Então, confira nas páginas a } \\
\text { seguir }\end{array}$ & $\begin{array}{l}\text { É possível } \\
\text { eliminar até } 6 \mathrm{~kg} \\
\text { em um mês }\end{array}$ \\
\hline $\begin{array}{l}\text { maio/ } \\
2015\end{array}$ & Boa Forma & Dieta do GH & $\begin{array}{l}\text { Quer deixar seu corpo assim: } \\
\text { magro e bem definido? } \\
\text { O que você ganha com isso? } \\
\text { Ops, perde! Pelo menos } 4 \\
\text { quilos em } 30 \text { dias }\end{array}$ & $\begin{array}{l}\text { - } 4 \text { kg em um } \\
\text { mês com } \\
\text { cardápio que } \\
\text { estimula o } \\
\text { hormônio do } \\
\text { crescimentos }\end{array}$ \\
\hline $\begin{array}{l}\text { julho/ } \\
2015\end{array}$ & Boa Forma & Dieta Flex & $\begin{array}{l}\text { Procurando um programa } \\
\text { detox que não corte } \\
\text { totalmente a carne do } \\
\text { cardápio? Então essa dieta é } \\
\text { para você }\end{array}$ & $\begin{array}{l}\text { - } 4 \text { quilos em } 30 \\
\text { dias }\end{array}$ \\
\hline $\begin{array}{l}\text { setembro/ } \\
2015\end{array}$ & Boa Forma & Dieta do Cortisol & $\begin{array}{l}\text { Controle o hormônio do } \\
\text { stress e não deixe que ele } \\
\text { engorde você }\end{array}$ & $\begin{array}{l}\text { Enxugue } 4 \mathrm{~kg} \\
\text { (ou mais) em } 1 \\
\text { mês }\end{array}$ \\
\hline $\begin{array}{l}\text { outubro/ } \\
2015\end{array}$ & $\begin{array}{l}\text { Corpo a } \\
\text { Corpo }\end{array}$ & $\begin{array}{l}\text { Dieta da Caloria } \\
\text { Negativa }\end{array}$ & $\begin{array}{l}\text { Ficou animada? Então, adote } \\
\text { o cardápio [...] e dê adeus aos } \\
\text { pneuzinhos! }\end{array}$ & $\begin{array}{l}\text { Siga o cardápio } \\
\text { que você verá } \\
\text { nas próximas } \\
\text { páginas e } \\
\text { enxugue } 4 \text { quilos } \\
\text { em um mês! }\end{array}$ \\
\hline $\begin{array}{c}\text { novembro/ } \\
2015\end{array}$ & Boa Forma & Dieta em Circuito & $\begin{array}{l}\text { Não, você não vai ficar sem } \\
\text { comer (nem deve!). A } \\
\text { proposta é fechar a boca } \\
\text { numa faixa de horário para } \\
\text { que o organismo reequilibre } \\
\text { os hormônios e, assim, } \\
\text { elimine os excessos mais } \\
\text { facilmente }\end{array}$ & $\begin{array}{l}\text { Depois de um } \\
\text { mês, a balança } \\
\text { aponta } 1,5 \text { quilo } \\
\text { a menos }\end{array}$ \\
\hline $\begin{array}{l}\text { maio/ } \\
2017\end{array}$ & $\begin{array}{l}\text { Corpo a } \\
\text { Corpo }\end{array}$ & Dieta Budista & $\begin{array}{l}\text { Emagreça com a Dieta } \\
\text { Budista. } \\
\text { Faça e comprove! }\end{array}$ & $\begin{array}{l}\text { Focar a atenção } \\
\text { nos intervalos em } \\
\text { que ingerimos as } \\
\text { refeições é capaz } \\
\text { de eliminar até } 5 \\
\text { quilos na balança } \\
\text { em apenas } 30 \\
\text { dias }\end{array}$ \\
\hline
\end{tabular}




\begin{tabular}{|c|c|c|c|c|}
\hline $\begin{array}{c}\text { dezembro/ } \\
2017\end{array}$ & $\begin{array}{c}\text { Corpo a } \\
\text { Corpo }\end{array}$ & Dieta Alcalina & $\begin{array}{l}\text { Ainda dá tempo de dar um } \\
\text { jeito nos quilinhos extras } \\
\text { sempre precisar se cobrir } \\
\text { com a toalha. Como? }\end{array}$ & $\begin{array}{l}{[\ldots] \text { de quebra, }} \\
\text { resulta em um } \\
\text { emagrecimento } \\
\text { mais rápido que } \\
\text { o normal - dá } \\
\text { para eliminar até } \\
3 \text { kg por semana }\end{array}$ \\
\hline
\end{tabular}

Um efeito de evidência ideológica nesse discurso é a convocação peremptória e contínua, gerando efeitos de que a mulher precisa estar sempre up to date, em sintonia com as novidades sobre o corpo, moda, estilo, aparência, ou seja, de acordo com as condições de existência vigentes no momento. A ambiência midiática, em que as informações sobre as dietas circulam, parecem impor ao sujeito o desenvolvimento de uma nova capacidade, típica dos dias atuais: é preciso tudo saber, tudo conhecer, para tudo comentar, postar, reproduzir. É o que Payer (2005) denomina "sujeitos polivalentes", inseridos em um "ideal de uma supercomunicação, transparente, universal, polivalente e onipresente" (p. 22). Nos dias atuais, em que a informação está disponível a todo momento, não saber opinar sobre um determinado assunto é tido como desleixo ou falta de interesse, como se o sujeito não pudesse se desconectar de modo algum do mundo conectado.

Um outro grupo de nomes que elencamos não confere habilidades a um alimento específico, mas a um grupo de alimentos que, combinados, teriam a capacidade de emagrecer. De que maneira? Rapidamente, claro. Vejamos dois exemplos:

\section{Recorte 8:}

Dieta Clean $-5 \mathrm{~kg}$ em 21 dias. Este programa detox aposta nos alimentos "limpos" para livrar o organismo das toxinas e acelerar o metabolismo. Você perde peso e ganha pique! ${ }^{64}$

+ magra e + saudável com a Dieta Viking. Além de afinar $2 \mathrm{~kg}$ por semana, o estilo de alimentar dos povos escandinavos ainda ajuda a diabete, o colesterol, a pressão alta e as inflamações. Então prepare-se, pois chegou a hora de vencer essa batalha! [...] Pronta para ficar mais magra e saudável? ${ }^{65}$

Se a reportagem sobre a Dieta Clean fosse o roteiro de um filme, poderíamos dizer que o roteirista teria abusado dos clichês e chavões. De acordo com a matéria publicada na revista Boa Forma, a Dieta Clean sugere uma faxina no organismo, eliminando toxinas e

\footnotetext{
${ }^{64}$ Matéria da revista Shape (edição n. 68, p. 61).

${ }^{65}$ Matéria da revista Boa Forma (edição n. 640, p. 82-83).
} 
reestabelecendo o ritmo (ela não explica exatamente o que vem a ser esse ritmo) do metabolismo em três semanas. Conforme explicita o título da reportagem, o praticante poderia perder 5 quilos em 21 dias. A dieta - continua a reportagem - foi criada por um cardiologista uruguaio, Alejandro Junger, radicado em Nova York (escrita dessa forma, metade em português: "Nova", e metade em inglês, "York"). O fato do médico uruguaio não morar em um país latinoamericano como o Uruguai, mas sim nos Estados Unidos, e não em qualquer cidade, mas em Nova Iorque, confere efeitos de superioridade e prestígio ao criador da fórmula para emagrecer. Continua a reportagem: "dizem até que conquistou celebridades como as atrizes Demi Moore e Gwyneth Paltrow". Mais uma vez, a repetição discursiva apela para o endosso das celebridades, atrelando à dieta efeitos de eficácia, já que supostamente foi adotada por famosas atrizes do cinema americano. Curiosamente, a reportagem não confirma o fato, apenas joga a informação para o leitor de forma despretensiosa, porém sabemos que cada letra inserida nesses textos busca suscitar certos efeitos de sentidos, em detrimento de tantos outros.

Na Dieta Clean, temos o uso da palavra "detox" (programa detox aposta nos alimentos "limpos"). O "detox" está atrelado a uma série de possibilidades dietéticas: "semana detox", "programa detox", "suco detox", "alimento detox", "dieta detox”, "dieta clean”. Ao acrescentar o adjetivo "novo" à expressão "detox", mais possibilidades para emagrecer são colocadas à disposição do sujeito. A palavra "detox" como um dos recursos para perder peso é oriunda da língua inglesa (detox), uma maneira informal e abreviada da expressão detoxification (o processo de remover substâncias tóxicas de um determinado organismo) como o corpo. Ao atribuir à determinados alimentos ou exercícios o efeito de "desintoxicar" o corpo, o discurso midiático das dietas faz circular efeitos de sentidos de que o processo de emagrecimento passa por uma "limpeza" do organismo.

O corpo magro, esbelto, é um corpo "limpo", livre de toxinas e, desta forma, saudável. Os efeitos de sentidos sobre o gordo e a gordura são atrelados a um organismo "envenenado", “intoxicado". Gordo - ressalta Foxcroft (2014) - é um sinônimo para os imprestáveis, lentos, inertes, fracos, pobres, burros e sem atrativos. E também “intoxicados". No entanto, “o corpo não se desintoxica com suco", afirma a nutricionista Sophie Deram (Vines, 2016), ou provavelmente não se desintoxica com nenhum dos componentes sugeridos por dietas mirabolantes. Assim, o discurso das dietas inscreve sentidos dominantes:

\section{Recorte 9:}


Aproveite o sol com tudo em cima. Coloque em prática a dieta que seca 3 quilos por semana e turbina a saúde. Assim, você aproveita as férias mais magra e cheia de energia ${ }^{66}$

Traçando um paralelo com os enunciados anteriores (recorte 8), o corpo esbelto é um corpo "limpo", livre de toxinas, que está com "tudo em cima", com a saúde "turbinada" e "cheio de energia". Ao fazer ressoar efeitos sobre o corpo esbelto, o discurso das dietas reforça sentidos dominantes sobre um organismo que, ao desfrutar de determinado formato corporal (magro), goza de boa saúde e disposição. Há ainda um efeito de potência: o ato de emagrecer é fixado a uma saúde "turbinada", que está além de um organismo apenas saudável. Uma saúde turbinada nos remete a efeitos de um organismo extremamente ativo, destemido, robusto, inquebrável. Um organismo que tudo pode realizar, já que está repleto de energia e vigor. Ao indicar e fazer circular certos sentidos sobre o corpo magro, as formulações discursivas também marcam efeitos sobre a condição contrária. O corpo gordo é, assim, um corpo intoxicado, flácido (ao contrário de tudo em cima, ostenta um formato caído) e indisposto.

Um dos recursos linguísticos e discursivos é a dieta com o nome de um país ou região. Um exemplar é a Dieta Viking ou Dieta Nórdica, estruturada na alimentação praticada pela população de países como a Dinamarca, Suécia, Noruega, Finlândia e Islândia:

\footnotetext{
Recorte 10:

+ magra e + saudável com a Dieta Viking. Além de afinar $2 \mathrm{~kg}$ por semana, o estilo de alimentar dos povos escandinavos ainda ajuda a diabete, o colesterol, a pressão alta e as inflamações. Então prepare-se, pois chegou a hora de vencer essa batalha! [...] Pronta para ficar mais magra e saudável ${ }^{67}$
}

Segundo a matéria publicada na revista Shape (recorte acima), a dieta prioriza o consumo de alimentos naturais e orgânicos, com preferência para os grãos, frutos do mar, frutas, verduras e gorduras "boas". Provavelmente o consumo desses alimentos deve ser saudável do ponto de vista nutricional, e não faz parte deste trabalho fazer esse tipo de análise ou julgamento. O que nos chama atenção é a forma como a dieta é retratada em um espaço privilegiado de divulgação desse tipo de informação. Novamente podemos perceber todos os componentes dos enunciados atrelados à Formação Discursiva das dietas e boa forma. A Dieta Viking é discursivizada como um plano para emagrecer, afinar, perder quilos de forma rápida. Comparando os enunciados analisados até aqui, nenhuma novidade. Outro aspecto é que a

\footnotetext{
${ }^{66}$ Matéria da revista Corpo a Corpo (edição n. 348, p .42).

${ }^{67}$ Matéria da revista Boa Forma (edição n. 640, p. 82-83).
} 
relação da mulher com seu corpo é atrelada a uma batalha, que deve ser vencida. É preciso batalhar para emagrecer. Os sentidos inerentes à gordura corporal reforçam que a adiposidade é um inimigo a ser vencido. O que vai na contramão dos sentidos de facilidade e agilidade promulgadas por esses mesmos agentes discursivos. No discurso das dietas, aspectos contraditórios estão sempre adjacentes: de um lado, sugere a adoção de um regime para emagrecer rapidamente. Por outro, alerta: é preciso batalhar, isto é, empreender grandes esforços para superar grandes dificuldades. Afinal, emagrecer é fácil ou não? Essa tensão é constitutiva desse discurso. Ao indicar que a mulher deve travar uma batalha para perder peso, o enunciado produz ainda efeitos ao enaltecer o sujeito que conseguiu emagrecer e é visto como um batalhador, um vencedor.

O que mais nos chama atenção e está subjacente aos discursos como o da Dieta Nórdica, que se apropria de um país ou região para nomear uma modalidade de regime, são os efeitos de superioridade oriundos de uma nação que se supõe ser superior à nossa. Efeitos atribuídos ao estrangeirismo. Durante anos o mundo foi dividido geofisicamente em Primeiro, Segundo e Terceiro mundo. Este último, do qual estavam muitos países da América Latina, inclusive o Brasil, eram marcados por economias pouco desenvolvidas, fortes disparidades econômicas, baixa expectativa de vida e inúmeros problemas sociais. Mesmo que o Brasil tenha avançado em alguns quesitos, ainda continua longe de ser uma sociedade avançada em comparação a outras nações. O imaginário brasileiro carrega esse simbolismo. Apropriar-se discursivamente de algo adventício, "internacional", valorizando seu funcionamento, é conferir uma aura de sofisticação e distinção a um produto ou ideia. Há empresas que valorizam discursivamente o fato de serem brasileiras e produzirem artigos genuinamente nacionais. Porém ainda podemos notar, na mídia, enunciados que recorrem ao estrangeirismo como forma de valorizar certos aspectos na abordagem de um tema específico. A Dieta do Cortisol, proposta por outra publicação, aposta em uma vertente que sugere à leitora superar um dos problemas emocionais da atualidade: a tensão e o estresse.

\section{Recorte 11: \\ KEEP CALM AND PERCA PESO. Sabia que a culpa pelos quilos extras pode estar na pilha de relatórios em cima da sua mesa de trabalho? Stress engorda! Mas o que você coloca no prato é capaz de controlar o cortisol e reduzir a tensão - e o excesso de peso ${ }^{68}$}

\footnotetext{
${ }^{68}$ Matéria da revista Boa Forma (edição n. 347, p. 64).
} 
Todo discurso está inserido em um contexto. Ele não é produzido de forma estanque, mas embebido na/da totalidade das experiências perceptíveis e pelas realidades que o afetam e que nos afetam. Os fatos econômicos, sociais, políticos, culturais, etc., de uma época e de uma cultura interferem na produção e circulação dos discursos e, consequentemente, dos sentidos. Ora, se postulamos anteriormente que a mídia é a boca do mercado, e a indústria da dieta e boa forma está centrada na exploração e no lucro, as publicações impressas e virtuais são a "boca desse mercado". São elas que promovem a circulação dos discursos sobre dietas e boa forma, uma circulação que "se dá em certa conjuntura e segundo certas condições" (Orlandi, 2005, p. 9). Uma vez que a circulação "diz respeito aos trajetos dos dizeres que se dão em certas conjunturas”, constata Nunes (2008), ela “ocorre por 'meios' que nunca são neutros” (p. 86). Enquanto produto, uma publicação precisa produzir efeitos sobre um assunto que está produzindo sentidos (e, de certa forma, faz sentido) para um povo. Um discurso não é alheio à realidade, em especial a econômica. Tudo está conectado. "The world is a college of corporations inexorably determined by the immutable bylaws of business. The world is a business", argumenta o executivo Arthur Jensen no filme Rede de Intrigas.

A publicação onde o recorte acima foi veiculado é de setembro de 2015, período em que o Brasil enfrentava uma crise econômica, com forte recessão e aumento do desemprego. Não pretendemos, aqui, discutir a questão econômica ou política da crise, mas o aproveitamento cultural, simbólico e discursivo de um fato histórico por parte da mídia. A crise foi amplamente divulgada, debatida, questionada pelos mais diversos setores midiáticos. Cada qual com seu interesse. O fato histórico "crise" se tornou um produto midiático vendável. A circulação dos mais diversos discursos sobre a crise faz circular diferentes efeitos de sentidos sobre o momento que o país atravessou e parece ainda atravessar em 2017, agora em outra conjunção econômica e política. A questão é que quando a mídia aborda um assunto como uma crise econômica, ela ressalta principalmente os danos causados por essa mesma crise. Portanto, apela para os medos e anseios da população. O medo é um excelente insumo na venda de informação. O público não para de olhar o noticiário e isso tem a ver com o medo, diz Botton (2015, p. 46), pois o noticiário tem "fortes motivações comerciais para exagerar nossa vulnerabilidade. Naturalmente, ele precisa que seu público se sinta agitado, assustado e incomodado boa parte do tempo”. O medo da instabilidade econômica, por exemplo, é intrínseco ao receio do sujeito de perder o emprego e não conseguir manter o padrão de vida.

Outro aspecto é o estresse proveniente da pressão no trabalho, fator potencialmente agravado em um período de crise e desemprego. "Além de ocupar uma significativa parcela de tempo do dia, é nele [emprego] que o indivíduo vai lidar com prazos, cobranças, pressão, 
sucessos e falhas, entre muitas outras coisas que mexem com o emocional de qualquer um" (Oliveira, 2013, s/p), como o risco iminente de perder a ocupação. No primeiro parágrafo da reportagem sobre a Dieta do Cortisol, o texto fisga a leitora com um discurso relacionando a pressão no trabalho ao ganho de peso:

\section{Recorte 12: \\ Não é coincidência se, desde que você mudou de emprego, seu jeans ficou mais apertado. A pressão no trabalho e a correria do dia a dia podem fazer o ponteiro da balança subir. A culpa é do stress físico e emocional, que estimula a produção do cortisol - hormônio que, ao circular no nosso organismo em excesso, breca a perda peso e, pior, engorda ${ }^{69}$}

Certos discursos adquirem uma potência, uma força discursiva que faz circular efeitos sobre um assunto específico. Isso pode ser provocado por um fato concreto, como uma tragédia de grandes proporções, ou um movimento cultural que tem ganhado força como a discussão sobre gêneros sexuais na atualidade ${ }^{70}$. A relação entre a mídia e o mundo concreto se estabelece por uma via de mão dupla: tanto a mídia tem o poder de destacar a pauta mais importante em uma circunstância específica, quanto os fatos pautam a mídia. Mas a escolha nunca é ingênua. E os discursos sobre um tema ganham força por vários motivos, sendo um deles a capacidade midiática em estabelecer uma agenda para alguns assuntos em determinados momentos, balançando a atenção do leitor para um ou outro lado, para um ou outro tópico. Alguns temas terão mais audiência, outros serão esquecidos rapidamente.

O ambiente midiático, diz Silverstone (2005), está cada vez mais insistente e intenso, um elemento onipresente, uma dimensão essencial de nossa experiência diária, sendo praticamente impossível escapar à sua presença e a forma como apresente e representa o mundo. Claro que há sujeitos, espaços, textos que não estão submetidos ao jugo da mídia. No entanto, a força do texto da mídia, como bem define Payer (2005), passa a ter uma existência no meio social porque está apoiado em uma formação discursiva que os produz, os sustenta e os propaga. A linguagem e o sujeito, explica Payer (2005), podem ser "considerados como elementos a partir do interior dessa formação discursiva e que, apoiados nela, não existem independentemente dos discursos que os sustentam" (p. 21).

O oportunismo midiático pega carona em um momento sócio-histórico, como a crise econômica brasileira, que funciona discursivamente produzindo efeitos de sentidos, para vender

\footnotetext{
${ }^{69}$ Matéria da revista Boa Forma (edição n. 347, p. 64).

${ }^{70}$ Sobre esse tema destacamos a obra Do cárcere à invenção: gêneros sexuais na contemporaneidade (Garcia, Biziak e Sousa, 2017).
} 
a ideia de uma dieta vinculada a um hormônio capaz de controlar o estresse físico e emocional e, consequentemente, induzir a redução de peso. Tópicos como tensão, estresse, mudança de emprego, fadiga, alterações de humor, entre outros, são questões complexas e deveriam ser avaliadas e discutidas na mídia para fomentar um conteúdo capaz de ajudar a leitora em um momento de dificuldade. Orientar, por exemplo, quando e como procurar ajuda profissional. Contudo, o discurso midiático das dietas costuma recortar um ou outro aspecto que ele julga interessante para estabelecer uma ponte entre um fato real e histórico e o ato de emagrecer. $\mathrm{O}$ tema "estresse" é discutido em poucas linhas, funcionando como um gancho para o que vem a seguir: o texto convida a leitora a "virar a mesa" e "solucionar os estragos na cintura" por meio de um "cardápio anti-stress" e um "treino antitensão". "Desconecte-se dos seus problemas e mande embora o stress" $" 71$, ordena o texto.

Paradoxalmente, propor uma nova dieta sugerindo discursivamente que a mulher precisa “acalmar para emagrecer" pode ter o efeito oposto. As pessoas submetidas às dietas podem "perder o contato com seu apetite normal e ser capazes de manter apenas um arremedo de controle ao seguir as diretrizes de um plano de dieta" (Foxcroft, 2005, p. 250). Diante da autodepreciação de estar acima do peso e do anseio gerado por um processo dietético, que talvez funcione ou não, as pessoas que passam por um regime "têm mais probabilidade de apresentar um desempenho mental deficiente - a tensão de restringir o alimento é contínua e prejudicial" (Foxcroft, 2013, p. 250).

No interior dessa prática sócio-histórica, Payer (2005, p. 23) alerta que "fíca difícil nos esquivarmos dos efeitos dos enunciados do mercado, uma vez que a própria sobrevivência parece não poder se dar desvinculada dele, tal é a sua dinâmica”. Mas como a mulher atual pode escapar dos efeitos desse corpo que, segundo Goldenberg (2002), está cada vez mais submetido a coecções estéticas imperativas e geradoras de ansiedade? Coadunar um fato sócio-histórico ao ato de emagrecer (e permanecer em forma) seria a melhor forma de ajudar a leitora a atravessar um período de ansiedade e estresse? Provavelmente não! Há ainda um aspecto importante a ser considerado: praticar reiteradamente métodos dietéticos "põe em risco a saúde, mais até, talvez, do que ficar um pouco acima do peso. Já se determinou que ele está ligado a doenças cardiovasculares, derrames, diabetes - todos em ascensão no mundo ocidental" (Foxcroft, 2013, p. 249). "Difamar ou julgar o físico herdado de uma mulher é criar gerações e mais gerações de mulheres ansiosas e neuróticas”, defende Estés (2014, p. 233). Enquanto prática discursiva dotada de exponencial capacidade de interpelação dos sujeitos, o texto

\footnotetext{
${ }^{71}$ Matéria da revista Boa Forma (edição n. 347, p. 64).
} 
midiático das dietas e boa forma deveria repensar a formulação dos enunciados e das ideologias que apregoam.

\subsection{Acesso, logo emagreço: tecnologia, informação e celebridades}

Todas as revistas que compõem nosso corpus possuem site e redes sociais (facebook, instragam e twitter). Sodré (2002) adverte que, na contemporaneidade, a reflexividade institucional é agora o reflexo tornado real pelas tecnointerações, o que implica um grau elevado de indiferenciação entre o homem e sua imagem - o indivíduo é solicitado a viver, muito pouco autorreflexivamente, no interior das tecnointerações, cujo horizonte comunicacional é a interatividade absoluta ou a conectividade permanente. "Vídeo, tela interativa, multimídia, Internet, realidade virtual: a interatividade nos ameaça de toda parte”, atesta Baudrillard (2011, p. 129).

A tecnologia e, consequentemente, o espaço midiático virtual tornaram-se uma arma poderosa da indústria da boa forma na venda de produtos, exercícios, dietas e informações das mais diversas:

Somos bombardeados por meio da tecnologia, desde a série de discos de autoaprimoramento em vinil dos anos 1690, como "Reduce Through Listening" [Perca peso enquanto escuta], de Edward L. Baron, que "ajuda você a desenvolver aversão por alimentos que engordam", até os aplicativos de iPhone de hoje. Sempre no seu bolso, seu iPhone pode controlar sua ingestão de alimentos, e seu consumo de calorias. Você sempre pode sacá-lo quando um pedaço de comida o ameaçar ou quanto sentir vontade de comer algo inadequado. É possível estabelecer seus objetivos, registrar cada mordida, seguir diligentemente seu progresso e ver quanto peso você está perdendo ou ganhando, conseguir ajuda instantânea pela internet e ligações com empresas de regimes patenteados, alguns gratuitos, outros não, e afogar-se em propaganda (Foxcroft, 2013, p. 21 - grifos nossos).

Durante nossa pesquisa, a capa da revista Women's Health (edição n. 83) chamou nossa atenção por personificar a forma sujeito-celebridade-fitness, tão presente em nosso mundo tecnológico-virtual. É a forma sujeito que quanto mais aparece, mais vende. A capa estampou Gabriela Pugliesi ${ }^{72}$, definida pelas publicações de boa forma como "musa da vida saudável" e

\footnotetext{
72 Recuperado em 20 de maio de 2016, de http://www.tips4life.com.br/
} 
"top blogger"73, entre outros adjetivos. Através de um deslizamento de sentidos pelo efeito metafórico, a máxima "você pode chegar lá" ou "tenha sucesso profissional" (todas atreladas ao sucesso) são substituídas no universo da boa forma por expressões criadas por Pugliesi como "BundanaNuca", "FrangasSim MolengasJamais", "Asbundasagradecem”, "projetobundura"74 entre outras. Segundo Pugliesi, são manifestações desse tipo que a tornaram "popular" no universo virtual. A mídia é pródiga em produzir metáforas para incentivar o sujeito que persiste em alcançar o sucesso da boa forma, cujo ápice é o corpo-perfeito, moldando seu corpo ao ideal incentivado pela indústria da beleza. Em Análise do Discurso a metáfora não funciona como comparação ou substituição, mas como transferência que se produz num processo intermitente entre deslizamentos de sentidos (Brasil, 2011).

Uma reportagem sobre Pugliesi exalta a blogueira como alguém que tem se superado constantemente na busca de um "corpo ideal". A jornalista a define "\#Anovapugli", que dia após dia busca uma versão melhorada de si mesma. Aqui temos a ideologia do novo e da novidade (que veremos no próximo capítulo) fazendo ressoar sentidos na re(fabricação) do sujeito. O texto exalta ainda os resultados alcançados pela blogueira: “em um ano, ela mudou o corpo (que já era bonito e ficou escandalosamente definido) e reforçou suas atitudes positivas"75. Mudar no sentido de melhorar o formato, redesenhar suas curvas, atrelando essa re(significação) do corpo a um estado de espírito também melhorado.

Com as informações disponíveis no universo virtual sobre praticamente tudo, o sujeito não pode se dar ao direito de não obter sucesso - seja ele profissional ou pessoal (como um corpo-perfeito). Retomamos a máxima do mercado - o sucesso a todo custo. "Hoje, a aparência se tornou a coisa mais importante do mundo. [...] Tudo se concentra na aparência, ou no peso. Como se a balança fosse o indicador de estado de felicidade, bem-estar ou saúde e sucesso" (Deram, 2014, p.56). Os gordos não são bem vistos em nossa sociedade, e normalmente seus traços são considerados incompatíveis com o ideal do corpo-imagem imposto pela mídia. A falta de cuidado com o corpo como, por exemplo, a incapacidade de emagrecer, é frequentemente relacionado a desleixo e falta de comprometimento pessoal.

\subsubsection{Mais algumas considerações sobre a tecnologia: fé cega, faca amolada!}

\footnotetext{
73 Gabriela Pugliesi foi capa da revista Women's Health (edição n. 83), que faz parte do nosso corpus.

74 Recuperado em 1 de dezembro de 2015, de http://www1.folha.uol.com.br/colunas/monicabergamo/2015/09/1683683-sucesso-na-internet-gabrielapugliesi-sonha-com-televisao-sou-aparecida.shtml

${ }^{75}$ Matéria da revista Women's Health (edição n. 83, p. 48).
} 
Antes de continuar, vamos tecer algumas considerações sobre o gesto de leitura que fizemos e continuaremos a fazer sobre a tecnologia. Em primeiro lugar, não somos contra a tecnologia e seus avanços em diversas áreas. Não é possível negar a irrupção da internet na vida cotidiana. A professora e pesquisadora Lucília Maria Abrahão e Sousa, orientadora deste trabalho de pesquisa, já havia sinalizado que o século XXI nasceu:

\begin{abstract}
Com marcas de silício nas veias, embalado pelo ideário de liberdade, construído a partir da explosão das tecnologias de comunicação, especialmente aquelas que proporcionam velocidade, mobilidade $\mathrm{e}$ ubiquidade. A aldeola global e a Internet seriam as vedetes do novo tempoespaço e da modernidade-mundo, nas quais barreiras, diferenças e distâncias aparecem diluídas. Nesse contexto, emerge a textualidade eletrônica, remodelando os processos de leitura e escritas tais como os conhecemos. Os nós, em que os sujeitos se prendem nessa teia, são tão complexos quanto a conexão entre links na galáxia-internet; complexos, sobretudo, pela topologia multilinear que a rede inaugura, pela fragmentação de sentidos que ela proporciona e pelo apagamento das condições sócio-históricas de produção dos dizeres que ela promove. (Romão, 2014, p. 71).
\end{abstract}

A tecnologia e seus suportes midiáticos nitidamente influenciam o viver contemporâneo. Contudo, todo aspecto social pode e deve ser analisado sob vários ângulos e diferentes perspectivas. Com pertinência, Cristiane Dias (2012) aponta para o fato de que a tecnologia e a sociedade constituem um conjunto de questões importantes para se pensar o corpo, produzindo sintomas sociais como o emagrecimento através das dietas que circulam no ambiente virtual. No contexto da forma-histórica capitalista, que espécie de sujeito e de sentidos as novas tecnologias produzem? questiona Orlandi (2010, p. 16). A própria pesquisadora responde:

As TI cedem a um equívoco histórico, que é considerar o sujeito da ciência (da informação, no caso) como curiosamente autônomo pare escolher, se informar, e agir. De fato, ao produzir um modelo comunicativo de perfil individual, as TI oferecem como a "tomada" desde modelo informacional por uma prática de linguagem que acabe funcionando de forma normativa no ambiente eletrônico. [...] É bom lembrar que a posição do sujeito da informação e o modelo tecnológico disponível atualmente estão constituídos em um mesmo funcionamento discursivo histórico (Orlandi, 2003, p. 17).

Esse funcionamento nos faz retomar aqui a questão da ambiência midiática na qual o sujeito contemporâneo está mergulhado: basta um dispositivo eletrônico integrado à internet 
por uma rede de conexão sem fio e estamos diante de algo inimaginável cinquenta anos atrás. Isso é algo que faz parte das condições de produção de praticamente qualquer discurso que circula na atualidade. Se entendemos que as condições de produção compreendem fundamentalmente os sujeitos e a situação, o contexto sócio-histórico e ideológico no qual eles estão inseridos (Orlandi, 2009), não é possível pensar a produção de um discurso como o das dietas sem pensar no modo de circulação desse mesmo discurso proporcionado pelas novas tecnologias.

O lado positivo das tecnologias já é amplamente alardeado pelas corporações que as criam e promovem suas utilidades. Nossa reflexão tem como foco investigar o lado sombrio das tecnologias e do espaço virtual no universo midiático das dietas. Não se trata de um embate, apenas de delinear nosso campo investigativo e reflexivo, nosso gesto de leitura diante de nosso corpus. Não se trata, ainda, de divagar sobre qual período da história o sujeito teve melhores condições de vida, liberdade e autonomia. Éramos mais felizes antes do advento das tecnologias e do ambiente midiático tal qual o conhecemos atualmente? Não importa. As facilidades, os prazeres, as realizações pessoais e conquistas individuais e coletivas proporcionadas pela tecnologia e seus avanços não cabem nessa discussão (enquanto observados apenas pelo seu lado positivo). Esclarecido esse ponto, avancemos!

Como vimos anteriormente, foi no início dos anos 1920, após a Primeira Guerra Mundial, que se intensificou as formações sociais e ideológicas da era da esbelteza, do corpo magro (Foxcroft, 2013), juntamente com a ascensão da publicidade moderna (Gorz, 2005), apontada por Pêcheux (2011) em sua reflexão sobre a bio-psicologia da publicidade e propaganda. A publicidade é uma das principais ferramentas do capitalismo para aliciar o sujeito contemporâneo a consumir produtos e conceitos. Para os profissionais dessa área, as campanhas publicitárias (e todo processo de marketing) tem como objetivo ajudar o consumidor a fazer a melhor escolha no momento de adquirir um determinado produto. Não é bem assim. A guerra metafórica criada pelos profissionais do marketing, como bem ressaltou Pêcheux (2011), tem o poder de engajar o destino de milhões indivíduos, que tomarão esta ou aquela decisão. Na era da visibilidade exacerbada, a publicidade e a mídia aparecem como instrumentos capazes de influenciar campanhas políticas, derrubar governos, arruinar a vida de pessoas na internet ${ }^{76}$ e, principalmente, influenciar o ato de consumir. Na civilização avançada, diz Kamper (2016), a violência se manifesta no olhar - portanto, no ato de ver, na produção exacerbada de imagens que nos interpelam, no ato de ser e viver resumido à exterioridade.

\footnotetext{
${ }^{76}$ Sobre esse sugerimos a obra Humilhado: Como a era da internet mudou o julgamento público (Ronson, 2015).
} 
Em sua obra Vida para Consumo: a transformação das pessoas em mercadoria, Zygmunt Bauman (2008) assinala a transformação da sociedade de produtores em sociedade de consumidores ainda no final da década de 1920. Nessa nova sociedade de consumidores, "ninguém pode se tornar sujeito sem primeiro virar mercadoria, e ninguém pode manter segura sua subjetividade sem reanimar, ressuscitar e recarregar de maneira perpétua as capacidades esperadas e exigidas de uma mercadoria vendável” (Bauman, 2008, p. 20). Seguindo o raciocínio de Bauman, podemos inferir no caso das dietas o surgimento da forma sujeito corpo(re)fabricado, obrigado a um contínuo (re)fazer e (re)aperfeiçoar de si mesmo ${ }^{77}$. Corpo up-todate. A principal característica da sociedade de consumidores é, portanto, a transformação dos consumidores em mercadorias, impelidos a consumir incessantemente para sair da invisibilidade. Na era da informação, diz Bauman (2008), a invisibilidade é a morte. Na sociedade de consumidores, habitamos o espaço social do mercado, do sistema capitalista, que tem na obtenção do lucro sua principal finalidade.

Nesse contexto, nossas práticas sociais e nossos processos de subjetivação ocorrem sob a égide do mercado, do sistema capitalista, cujas armas para incitar o consumo são as técnicas publicitárias que circulam no ambiente midiático. Esse cenário tem o poder de influenciar a relação do sujeito contemporâneo com o seu corpo, já que

Não há corpo que não esteja investido de sentidos, e que não seja o corpo de
um sujeito que se constitui por processos nos quais as instituições e suas
práticas são fundamentais para a forma com que ele se individualiza, assim
como o modo pelo qual, ideologicamente, somos interpelados em sujeitos,
enquanto forma sujeito histórica [...] O corpo do sujeito é um corpo ligado ao
corpo social (Orlandi, 2002) e também isso não lhe é transparente, porque as
instituições com seus discursos silenciam isto, tratando o social
individualizado. O corpo do sujeito é, nas condições sócio-histórica em que
vivemos, parte do corpo social tal como ele está significado na história. Isto
quer dizer, entre outras coisas, que o sujeito relaciona-se com o seu corpo já
atravessado por uma memória, pelo discurso social que o significa, pela
maneira como ele se individualiza (Orlandi, 2012a, p. 93).

Retomamos o que já dissemos anteriormente: a memória do formato contemporâneo do corpo e o discurso social que o significa produz e faz circular sentidos de um corpo magro, enxuto, esbelto, indiferente aos resquícios do viver, como se o corpo não sofresse as vicissitudes da vida e do seu próprio envelhecimento. O corpo do qual tratamos, discursivizado, um texto da cultura que ora revela, ora esconde, é o corpo produzido pela ideologia capitalista, em que

\footnotetext{
${ }^{77}$ Voltaremos a abordar a forma sujeito corpo-(re)fabricado no capítulo 4.
} 
pesam as coerções e imposições do econômico, a tirania do consenso, a crença nas soluções autoritárias, o peso do midiático, a inflação da imagem, a alienação no virtual, entre tantos outros aspectos (Orlandi, 2012a).

Se o indivíduo é interpelado pela ideologia capitalista, que tem no consumo sua principal finalidade, e seu corpo está atado ao corpo social, o sujeito e seu corpo funcionam estruturados "pelos modos de produção da vida material que condicionam o conjunto dos processos da vida social e política" (Orlandi, 2012a, p. 95). O universo midiático das dietas compõe, assim, uma gigantesca possibilidade do mercado de produtos para emagrecimento de incitar o consumo de tudo aquilo que o sujeito pode lançar mão para tentar moldar sua estrutura física ao corpo da ideologia dominante - o corpo perfeitamente magro. E isso se reflete de forma concreta, movimentando expressivos valores econômicos na venda de produtos destinados a alterar a imagem corporal. Se "as dietas da moda são pouco mais que inúteis", "são as que rendem melhores negócios" argumenta Foxcroft (2013, p. 11). Um exemplo ocorre aqui mesmo, no Brasil, terceiro maior mercado consumidor de produtos ligados à beleza. Cerca de 4,8 milhões de pessoas trabalham nesse setor no país (dados de 2015), cujo faturamento em 2014 foi de R 101 bilhões, 1,8\% por cento do PIB nacional ${ }^{78}$. "A cobiça e o lucro movem o mercado das dietas", afirma Foxcroft (2013, p. 22).

Até produtos que atualmente são considerados vilões da saúde já foram anunciados por campanhas publicitárias como sendo benéficos na luta contra a balança. Anúncios dos anos 1920 e 1930 promovendo a marca de cigarros Lucky Strike diziam: "Pegue um cigarro em vez de um doce" (Foxcroft, 2013). As revistas de boa forma e seus tentáculos virtuais (sites e redes sociais) oferecem diversos produtos (de cremes à equipamentos de radiofrequência para acabar com a celulite), modalidades de regime (novas dietas e suas supostas novidades), exercícios (e todos os itens necessários à prática de atividades físicas), alimentos (que agora são denominados "funcionais").

O que a celebridade estampada na edição deste mês usa para ter esse corpinho sequinho e definido? Ela revela seus segredos: sua alimentação, os exercícios que pratica e produtos que usa para modelar seu corpo. Compre determinados produtos e emagreça! Faça exercícios e emagreça! Alimente-se igual à celebridade e obtenha o mesmo corpo que estampamos na capa de nossa revista. O sujeito é interpelado a ter um corpo magro. Não há espaços para o corpo que esbarra na realidade, mas falaremos isso mais adiante. A performance da linguagem

\footnotetext{
78 Recuperado em 8 de setembro de 2013, de http://g1.globo.com/globonews/contacorrente/noticia/2015/03/setor-de-higiene-perfumaria-e-cosmeticos-faturou-r-101-bi-em2014.html
} 
midiática/publicitária faz parte de "um modo de enunciação certeiro e firme, sem indecisões, tropeços, sem reticências ou rupturas sintáticas. Em suma: um modo de enunciação determinado, que produza efeitos de certeza" (Payer, 2005, p. 12). Essas formulações no imperativo indicam, discursivamente, um conjunto de preceitos e ordens que devem ser seguidos pelo sujeito; este, por sua vez, deve obedecê-las, segui-las cegamente, sendo conduzido pelo que o discurso midiático propõe como efeito de verdade. No discursivo das dietas, não é possível - e estamos batendo nesta tecla desde o início de nossas reflexões distinguir jornalismo de publicidade.

O que entendemos por tecnologia, portanto, está além dos chips, cabos, circuitos, redes de fibra ótica, wireless e máquinas cada vez mais complexas como computadores ou aparelhos de celular. A tecnologia abarca tudo aquilo que potencializa o discurso e promove sua eficácia discursiva, englobando a "área político-econômica (globalização) e científica" (Dias, 2012, p. 43), a apuração e o refinamento da linguagem, a alteração técnica das imagens, a ambiência midiática ${ }^{79}$. Um exemplo das formações sociais e condições de produção do discurso produzido pelo mercado das dietas (mídia, publicidade, tecnologia e consumo) é a anteriormente citada Gabriela Pugliesi. Exemplo de celebridade virtual, com 1,5 milhão de "seguidores" em dispositivos virtuais, tem sido destaque em várias publicações. Estampou a capa da revista Women's Health (edição de setembro de 2015) e, em menos de um mês, foi destaque em jornais e revistas de grande circulação no País, como o jornal Folha de S. Paulo ${ }^{80}$ e Revista Veja ${ }^{81}$.

\footnotetext{
79 Ainda sobre a tecnologia pensada em um conceito mais amplo, no próximo capítulo falaremos sobre os Tecnobergs (montanhas tecnológicas).

80 Recuperado em 30 de outubro de 2015, de http://www1.folha.uol.com.br/fsp/ilustrada/233631-monicabergamo.shtml

81 Recuperado em 15 de novembro de 2015, http://vejasp.abril.com.br/materia/rotina-musas-fitness-jujusalimeni-karina-bacchi-gabriela-pugliesi
} 


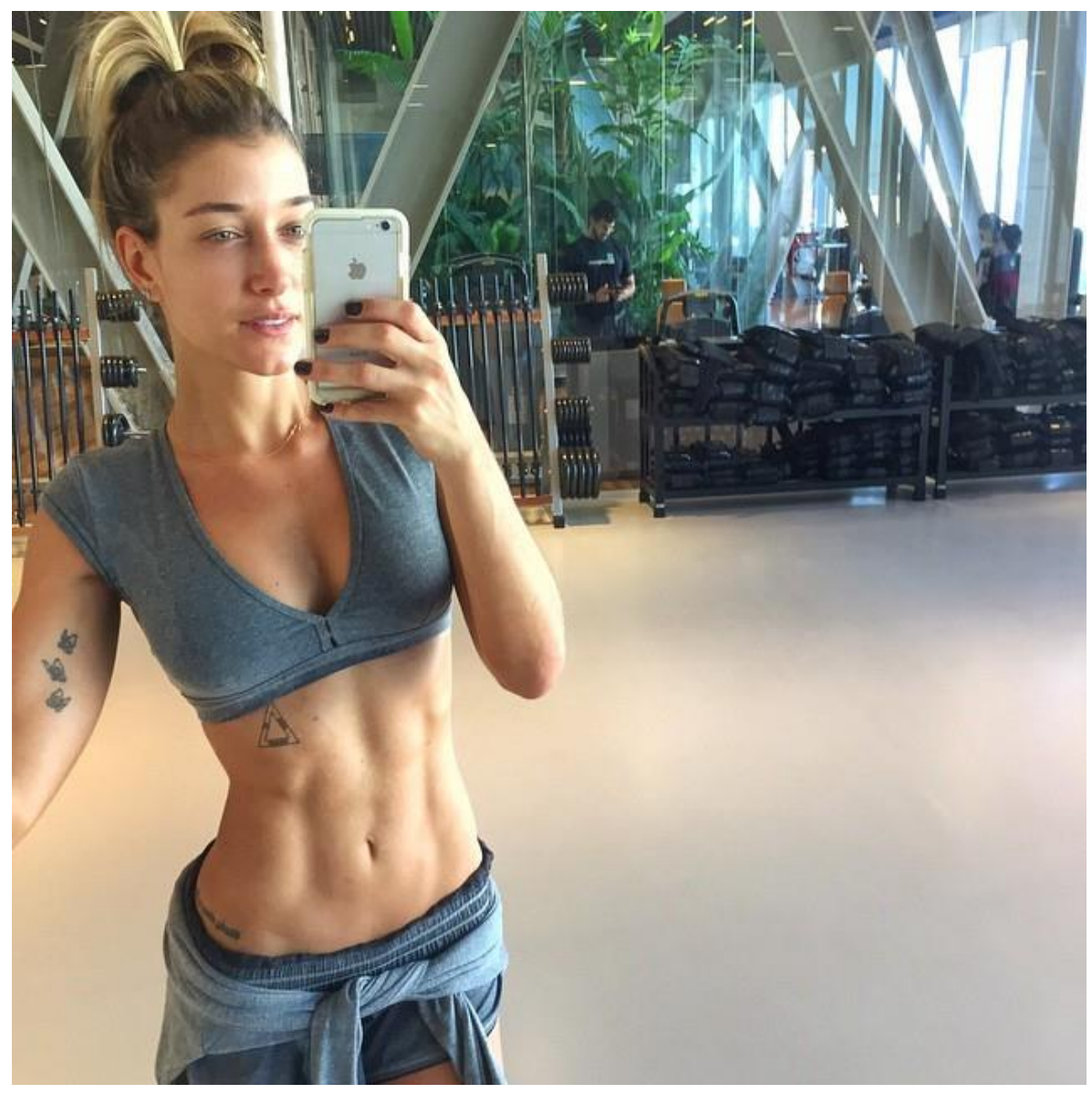

Figura 9. A musa fitness Gabriela Pugliesi ${ }^{82}$

A blogueira tornou-se famosa ao expor na internet os exercícios físicos e as dietas que pratica. Atualmente, também expõe sua rotina em seu site: festas, viagens, jantares, vida amorosa e atividades físicas. Um dos principais exemplos da forma sujeito-celebridade-fitness, Pugliesi opera o axioma "quanto mais aparece, mais vende". A imagem das celebridades, portanto, de seus corpos, é um ativo financeiro extremamente lucrativo. Quem consegue emagrecer e expor sua "nova forma" e sua "barriga tanquinho" também tem chance de virar notícia ou até mesmo celebridade. Entra em cena o primeiro mandamento da vida atual segundo o jornalista e escritor Roberto Saviano (2014): quanto mais você se comunica mais é feliz, quanto mais se comunica mais goza a vida, mais comercia sentimentos, mais vende, vende mais qualquer coisa, mais e sempre mais. Acesso, logo emagreço. Emagreço, logo existo! Existo, logo apareço! Apareço, logo lucro! 
O sujeito contemporâneo apresenta uma relação peculiar com a fama, os famosos e seus corpos (vide recortes 3, 4 e 5). A questão é: por que que as pessoas querem ficar famosas? Engana-se quem respondeu apenas o apetite por dinheiro, luxo, sexo e poder, provoca Botton:

Na verdade, o que move a vontade de ser famoso é o desejo por respeito [...] $\mathrm{O}$ desejo de ser famoso é uma tentativa de fazer com que nossa dignidade seja respeitada em um mundo em que quase certamente não o será, a menos que estejamos preparados para recorrer a medidas extremas. Podemos ser iguais perante a lei e as urnas, mas não há garantia de dignidade no tratamento que recebemos no escritório, na vida social ou nas burocracias governamental ou comercial. Sobretudo nas grandes cidades, esses polos de brutalidade em relação ao que é comum [...] O respeito é um bem escasso e estritamente racionado, e a indiferença é a norma (Botton, 2015, p. 156).

Ao estampar diversas capas de revistas e ser o foco de notícias em jornais e sites, divulgando um "manual para o aperfeiçoamento do corpo", Pugliesi é mais uma das diversas celebridades midiáticas a serviço da indústria da beleza. "Sei que eu vendo", disse a blogueira em entrevista publicada no Jornal Folha de S. Paulo ${ }^{83}$. A necessidade de emagrecer, atrelada a facilidade de acesso às informações sobre dietas e boa forma proporcionada pelo virtual, além da exposição midiática de celebridades como Pugliesi, faz com o sujeito fique aprisionado ao que Foxcroft (2013, p. 21) denominou "modo dieta-pânico", tentando qualquer coisa para perder peso, sentindo a pressão de todos os lados e a infelicidade por dentro. O indivíduo que está acima do peso é, em suma, atropelado pela avalanche de informações sobre um corpo irreal. Nesse processo de inscrição do corpo e do sentido da própria vida social (Dias, 2012), não há desculpas para o sujeito que não atinge os padrões de excelência, sucesso e autorrealização. “Como evidencia o noticiário com suas constantes histórias de iniciativa, perseverança, esforço", diz Botton, “em tese não há limites para o que qualquer um pode alcançar” (2015, p. 148).

O sujeito contemporâneo parece não refletir sobre o papel desempenhado por figuras como Pugliesi, que divulgam produtos e serviços para emagrecer (e são bem remuneradas para isso) e vivem rodeadas por inúmeros recursos (academias e aparelhos de ginástica) e profissionais (nutricionistas, preparadores físicos) que a ajudam a esculpir seu corpo atlético. O corpo das blogueiras fitness são tomados como "corpo performance", ou seja, "são experimentações do corpo que têm a tecnologia como possível ideal de perfeição [...] um corpo

83 Recuperado em 30 de outubro de 2015, de http://www1.folha.uol.com.br/fsp/ilustrada/233631-monicabergamo.shtml 
que se torna informação: imagem numérica" (Dias, 2012, p. 38). Além do modo dieta-pânico, o sujeito que se vê afogado no universo virtual e midiático da boa forma e não consegue emagrecer passa a viver uma espécie de "pânico existencial" (Botton, 2015). Ao observar o trabalho dos homens-sanduíche ou homens-placa nas ruas de São Paulo (Sanches, 2009), propus um novo tipo de corpo imposto pela sociedade das imagens: o corpo-anúncio. Posto que o homem-sanduíche é uma mídia eminentemente visual, sua visibilidade repousa em sua capacidade particular de mediação, que controla a percepção e atrai a atenção do observador. Partindo do pressuposto de que o corpo do homem-sanduíche, assim como sua placa, atua como uma mídia, tal corpo tende à dissimulação para o nascimento de uma imagem, dando origem ao corpo-anúncio.

Ao expor seu corpo em seu site e redes sociais (e lucrar com isso), Gabriela Pugliesi também pode ser considerada um corpo-anúncio. "Há três anos, ela rouba a cena nas mídias sociais com seu perfil fitness" ${ }^{\text {" }}$. Além do corpo-anúncio, a blogueira é uma evolução na escalada midiática dos corpos que atuam como suportes midiáticos: ela é um exemplar da forma sujeito corpo-projeto. O corpo-projeto é mais refinado que um corpo-anúncio, é algo a ser admirado pelos pobres mortais que se encontram do lado de cá das telas dos dispositivos eletrônicos. O corpo-projeto é um projeto de corpo idealizado pela mídia que se impõe sobre as condições de existência do sujeito (no nosso corpus de análise, especialmente sobre as mulheres), afetando a forma como o corpo significa e é significado em diferentes espaços de existência. Ele se manifesta principalmente no universo da boa forma, e ganhou exponencial divulgação com o advento do virtual. O corpo de Gabriela Pugliesi funciona discursivamente como uma beleza sobrenatural, um propósito que desafia a todos nós, em especial aqueles que se sentem pressionados justamente por não apresentarem a referência de beleza de nosso tempo. O modelo imposto pelo corpo-projeto é dissonante da realidade trivial do sujeito de nossa época. Trata-se de um ideal midiático: o corpo-projeto é também um corpo-imagem.

O complexo fenômeno dos corpos-imagens - analisa Baitello (2012) - é uma das demonstrações do poder das imagens sobre os corpos. Já o corpo-projeto vai além: é uma beleza idílica, um sonho a ser realizado, invejado, um projeto que, de tão perfeito, é insuperável. Em oposição à imagem do corpo-projeto está a forma sujeito corpo-abjeto. Ao contrário do corpoprojeto, a nossa verdadeira estrutura física (feita de carne e osso e envelhecida com o tempo) é a forma sujeito corpo-abjeto, desprezível aos olhos da mídia, com pouco ou nenhum valor midiático, pois não estampa capas ou sites de revistas, não está atrelada ao sucesso imposto

\footnotetext{
${ }^{84}$ Matéria da revista Women's Health (edição n. 83, p. 50).
} 
pelo mercado. No entanto, o corpo-abjeto deve empreender todos os esforços para obter os traços ideais do corpo-projeto. E esse esforço é, muitas vezes, feito isoladamente, totalmente independente dos outros. Na época em que vivemos, seguir os próprios interesses parece a coisa mais sensata e gratificante que uma pessoa pode fazer, diz Elias (2001).

Ao fazer uma reflexão sobre o corpo e a tecnologia, Giorgenon considera que

A interpelação do sujeito pela ideologia, na qual assinalamos que o poder do
Mercado é sustentado por formações ideológicas materializadas em
formações discursivas que atravessam o dizer dos sujeitos, que, ao se
identificarem ao que podemos nomear de formação discursiva do mercado,
constituem também o que podemos nomear como forma-sujeito do mercado a
qual caracteriza uma posição-sujeito no discurso com seu corpo (2016, p. 55).

Em um tempo de corpos-imagens e corpos-projetos, a forma sujeito corpo-abjeto se identifica com a ideologia das dietas e do corpo perfeito desejando a silhueta das musas fitness do momento e lutando para obter um corpo "sequinho" e "definido". Um corpo sempre jovem e jovializante. Se o sujeito buscava na religião e, mais tarde, na medicina a continuidade (real ou simbólica) de sua existência, hoje é a tecnologia que oferece a possibilidade de superação da morte do corpo e a finitude do tempo (Dias, 2012, p. 43). As blogueiras fitness compartilham seus segredos de boa forma com todos nós, e só depende de cada sujeito obter suas medidas invejáveis. É preciso gastar mais tempo e dinheiro nas academias, comprar produtos que prometem resultados rápidos, seguir as dicas dos sites e blogs da moda, praticar exercícios físicos em casa nos poucos momentos que sobram da rotina diária sufocante da imensa maioria dos indivíduos. 


\section{Capítulo 4}

\section{O NOVO E A NOVIDADE}

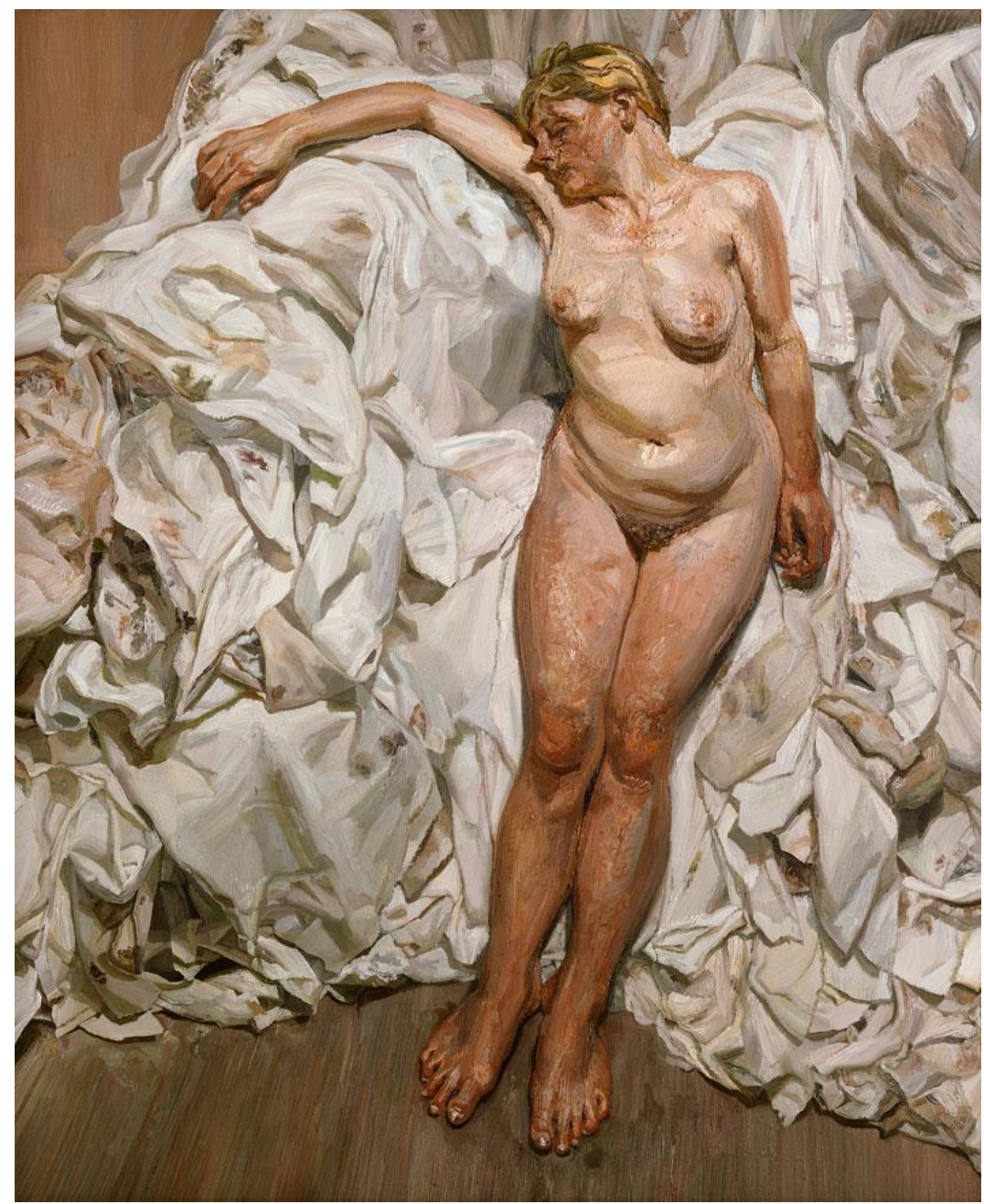

Standing by the Rags (Lucian Freud, 1988-1989)

Só uma única vez podemos fazer uma coisa pela primeira vez; é uma única vez que podemos ter prazer em sua novidade.

Penso que para o verdadeiro apaixonado por Veneza a cidade está sempre na ordem do dia. Certamente nada há de novo a dizer sobre ela, mas o velho é melhor do que qualquer novidade. Seria de fato triste o dia em que houvesse algo de novo a dizer. 


\subsection{A ideologia do novo e da novidade: acúmulo e repetição}

Uma das principais características do discurso tecnológico-midiático é sua maneira de conceber a dinâmica das relações humanas e sociais sempre em direção ao futuro. E sempre produzindo algo novo, pronto para ser desejado e consumido. Parafraseando Henry James (2013) ao falar de Veneza e da vida veneziana no fim do século XIX, nossa época colocou o passado em repouso, e o presente é tão estrangeiro, tão descontínuo, tão semelhante a uma multidão num cemitério sem coroas de flores para os túmulos.

São inúmeros os exemplos de discurso sobre as novas dietas, suas novidades e, de acordo com as empresas ou sujeitos que as propagam em revistas impressas ou no ambiente virtual, seus inúmeros benefícios. Basta uma olhada rápida ao nosso redor para ver a quantidade de novos dispositivos, funções, linguagens (o si informático; Le Breton, 2003) e, claro, informações que nos atingem diariamente. Usamos o verbo "atingir" porque somos, necessariamente, alvejados por uma avalanche de novas informações e imagens sem que possamos reagir (ou refletir) de forma adequada. Dia a dia, somos atropelados por um imenso aglomerado de informações. Não apenas recebemos, mas temos acesso a inúmeras possibilidades de geração e disseminação de informação. Essa é uma das características da sociedade tecnológico-midiática: tudo ao mesmo tempo agora. Nesse contexto tecnológicomidiático, chama atenção o discurso em circulação na atualidade do novo e da novidade. Mas será que tudo o que é novo é bom? Precisamos de tudo que é novo? Para explicar o fenômeno midiático global e suas consequências, René Armand Dreiffuss (2003, p. 105-107) criou o acrônimo Tecnobergs ${ }^{85}$, que, em analogia com "montanhas de gelo" (icebergs), são "montanhas tecnológicas", que tornam o consumidor - individual, corporativo ou institucional - um reformulador de práticas do cotidiano, um cidadão "consumido". Em outras palavras, é a ideologia do mercado e suas práticas discursivas interpelando o sujeito contemporâneo.

Na letra "E" do acrônimo Tercnobergs - "engenharia de novas concepções" - Dreiffus analisa todos os dispositivos tecnológicos e midiáticos que insistem em produzir o novo, a novidade, novas imagens, novos discursos que industrializam o espírito na busca incessante pela universalização de mentes e coisas. Nessa etapa da pesquisa, nossa proposta é iniciar uma

\footnotetext{
85 Dreiffus explica cada item de seu acrônimo no artigo "Tecnobergs globais, mundialização e planetarização", publicado em “Por uma outra comunicação: Mídia, mundialização cultural e poder" (Moraes, 2003).
} 
discussão sobre a constituição, produção e circulação do discurso do novo e da novidade ${ }^{86}$. Mas qual é o sujeito que fala, ou repete, ou que corresponde de forma quase automática a tudo o que é novo e enseja uma novidade? Antes de respondermos a essa questão precisamos compreender os alicerces que sustentam o discurso do novo e da novidade. Vários são os aspectos que dão sustentação a esse processo, porém dois deles se destacam: a repetição e a velocidade de disseminação de informações e imagens, processos típicos dos discursos midiáticos contemporâneos.

Todo fenômeno social de largo alcance gera linguagem própria ou, pelo menos, uma prática discursiva pela qual se montam e se difundem as significações necessárias à aceitação generalizada de um determinado fenômeno (Sodré, 2003). Na mídia atual, o discurso do novo e da novidade aparece como uma prática linguística recorrente na divulgação de coisas e conceitos. O discurso midiático do novo pode ser observado em diversos produtos, como cosméticos, produtos esportivos, medicamentos e, principalmente, dispositivos tecnológicos de criação e distribuição de informação (tablets, smartphones, computadores, etc.). É incrível a gama de produtos, ideias ou serviços cujas campanhas de marketing recorrem aos efeitos de sentidos proporcionados pelo novo e pela novidade para impulsionarem suas vendas. Vejamos um exemplo ${ }^{87}$ :

\footnotetext{
${ }^{86} \mathrm{O}$ discurso do novo e da novidade é um dos pontos da pesquisa que já vem sendo discutido em outros espaços de reflexão. Um deles é o artigo "O corpo do/no discurso midiático das dietas: efeitos do novo e da novidade" (Sousa e Sanches, 2018). Além das dietas, temos observado essa regularidade linguística em diferentes esferas, a exemplo do universo automotivo. Nossos primeiros estudos a respeito do novo e da novidade foram expostos em dois capítulos de livros: "Velocidade, memória metálica e o discurso contemporâneo do novo e da novidade" (Sanches e Romão, 2014) e "Admirável carro novo: o envelhecimento precoce de discursos e coisas" (Sanches e Romão, 2014). Este último também foi apresentado e publicado, em uma versão revista e ampliada, nos anais do XIV Congresso Ibero-americano de Comunicação - IBERCOM 2015 sob o título "O discurso eletrônico do universo automotivo: um estudo sobre o novo e a novidade" (Sanches, 2016). Esse tópico da pesquisa é fruto e também uma continuidade dessas reflexões, agora com o olhar voltado para entender como esse mesmo discurso produz sentidos no espaço midiático das dietas.

${ }^{87}$ Recuperado em 5 de junho de 2016, de http://www.samsung.com.br/galaxys6
} 


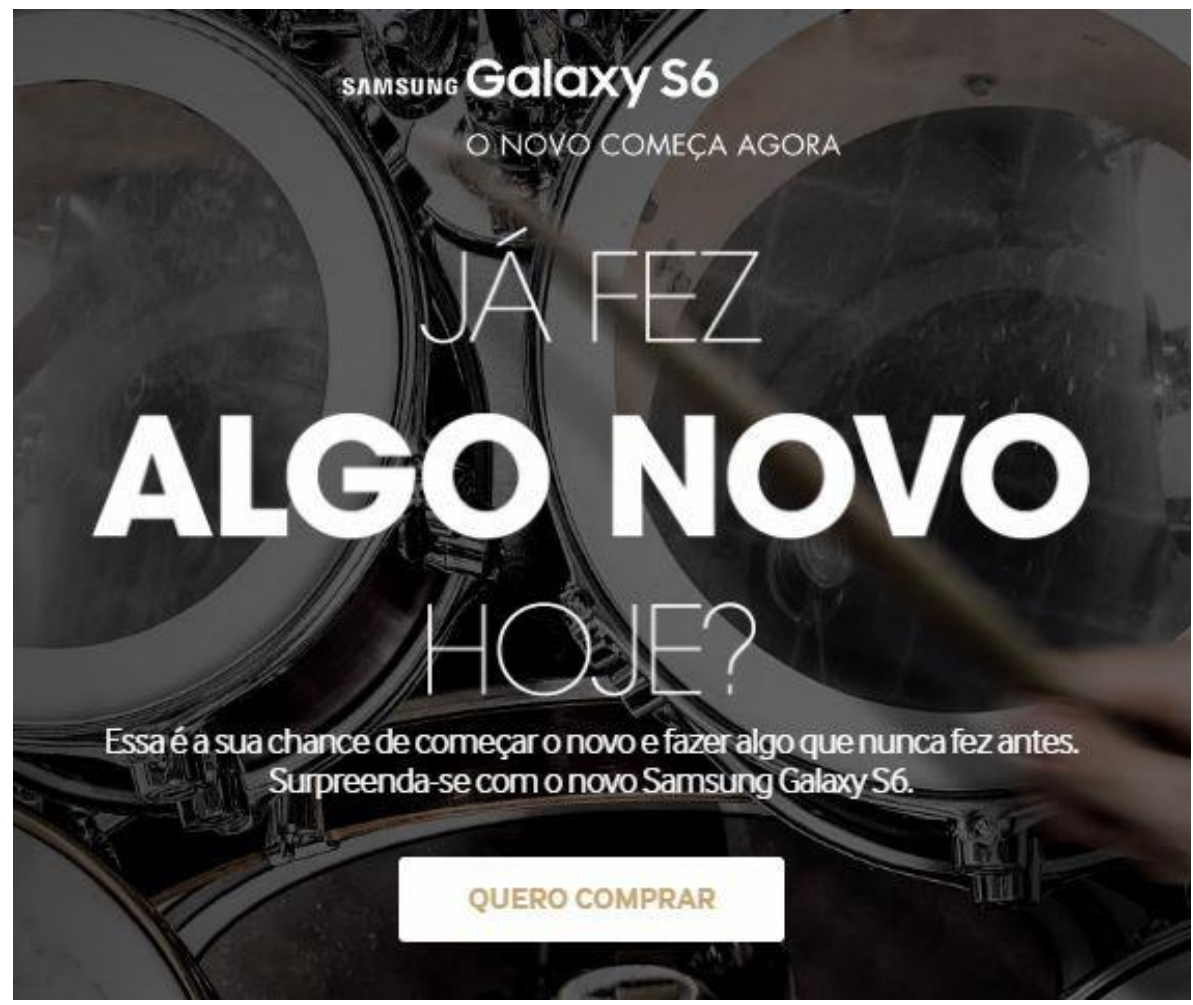

Figura 10

Uma fabricante de aparelhos de celular convoca o sujeito-consumidor a "começar algo novo", algo nunca feito antes. De preferência, comprando um aparelho de celular que se supõe totalmente novo, capaz de surpreender o seu usuário pelos recursos tecnológicos que oferece. $\mathrm{Na}$ figura 10, em um anúncio de apenas alguns centímetros a palavra "novo" é usada quatro vezes. Além da repetição (que veremos mais adiante em outros exemplos), o site da empresa interpela o sujeito-consumidor atrelando o novo aparelho a algo típico da sociedade atual: onde há algo novo, há inovação. Como dissemos anteriormente, o sujeito contemporâneo deve fazer todo o esforço necessário para fabricar a si mesmo em algo consumível, em corpo-mercadoria (seja para o mercado de trabalho, para os relacionamentos, para a vida social). É preciso atingir patamares de excelência em todas as esferas. Nesse cenário, não há espaço para a falha, a incompletude, a sombra, o medo, o déficit. Diz o site do fabricante que o aparelho possui um "Desenho inigualável: inovação em metal e vidro em um smartphone que mais parece uma obra de arte" 88

O uso dos adjetivos "novo", "inigualável”, além da expressão "mais parece uma obra de arte" retratam a tentativa da empresa em se diferenciar de produtos semelhantes disponíveis

\footnotetext{
${ }^{88}$ Recuperado em 5 de junho de 2016, de http://www.samsung.com.br/galaxys6
} 
no mercado. A concorrência é grande - outra fabricante de aparelhos eletrônicos diz: “A Apple traz inovações para o mundo com o iPhone, iPad, Mac, Apple Watch, iOS, OS X, watchOS e mais. Entre no site para comprar e obter suporte" ${ }^{\text {89 }}$. As pretensões das empresas globais não são pequenas: "inovações para o mundo" é o que oferecem aos sujeitos que, interpelados pela ideologia do mercado, pelo "texto da mídia" (Payer, 2005), buscam a perfeição e a garantia de pertencimento à sociedade capitalista midiatizada .

Em outra imagem a fabricante de veículos Fiat (Fabbrica Italiana Automobili Torino) divulga em sua página na internet o automóvel Uno 2015:

NOVO

DESIGN $\mathbf{N}_{\text {ехтеме }}$

\begin{abstract}
O design do Novo Uno 2015 reflete a nova fase do modelo: a evolução. Ele mudou, mas sem perder o revolucionário conceito round square, o "quadrado redondo", único e diferenciado. O novo design que agora conta com novos faróis e lanternas, capô, grade dianteira e parachoques ressaltam ainda mais as linhas e contornos do modelo,

transmitindo maior robustez e mais esportividade. Parachoques dianteiro e traseiro exclusivos com difusores aerodinâmicos, e saida de escape dupla central e ainda rodas de liga leve aro $15^{\text {"podem }}$ ser encontrados na versão sporting. Nas versões Way, Evolution e Sporting, a seta integrada ao retrovisor vem como item de série. Surpreenda-se com a evolução do Novo Uno 2015.
\end{abstract}

\title{
NOVOS FARÓIS
}

NOVA GRADE SUPERIOR

NOVO CAPÔ

NOVO PARACHOQUE DIANTEIRO E TRASEIRO

SETA INTEGRADA AO RETROVISOR

Figura 11. Trecho do site de divulgação do Novo Uno $2015^{90}$
89 Recuperado em 5 de junho de 2016, de https://www.google.com.br/search?q=apple\&oq=apple\&aqs=chrome..69i57j69i60j69i59j69i61/2j69i60.727j0j7 \&sourceid=chrome\&ie=UTF-8
${ }^{90}$ Recuperado em 15 de março de 2015, de http://www.fiat.com.br/carros/novo-uno.html 
A empresa enumera as características do modelo:

\begin{abstract}
Recorte 1391:
Novo design extremo; novos faróis; nova grade superior; novo capô; novo parachoque dianteiro e traseiro; nova personalização externa; novo sistema start \& stop; novo volante multifuncional; novo painel com textura exclusive; novo interior; novo câmbio Dualogic Automatic Plus; novo quadro de instrumentos; novo banco traseiro bi partido; novos bancos mais envolventes e confortáveis; nova central multimídia com tela de 6,2 "; novo rádio connect; nova personalização interna; nova chave de seta; novas rodas de liga leve.
\end{abstract}

Ao apresentar esse exemplo durante um congresso (Sanches, 2015), mostramos as imagens dos modelos anterior e do novo veículo anunciado pela Fiat e instiguei a plateia a apontar qual seria o mais recente que, segundo a campanha publicitária, possui tantas novidades (no recorte 13 o adjetivo novo(s)/nova(s) é citado 19 vezes, marcando um efeito de repetição). A chance de acertar era pequena: as imagens mostravam dois veículos praticamente iguais.

Ao analisar a circulação do novo e da novidade no universo automotivo (Sanches e Sousa, 2014), é possível notar que essa prática discursiva faz parte de um conjunto de mecanismos linguísticos que se constituem sócio-historicamente. Ao trocar o seu veículo por um modelo mais novo, imbuído de vetores simbólicos do novo e da novidade, o sujeito é interpelado por determinadas formações discursivas. O discurso midiático do novo e da novidade produz sentidos no universo real e imaginário, tendo como base alguns parâmetros e fundamentos $^{92}$ desse mesmo discurso (Sanches \& Sousa, 2014, p. 66):

1 - só o que é novo, para a sociedade contemporânea, é bom;

2 - para ser desejado, necessita ser rapidamente atualizado;

3 - o quanto a satisfação gerada por um produto, ideia ou serviço é fugaz;

4 - o quanto um produto, ideia ou serviço é perecível;

5 - o quanto a novidade é construída a despeito da vida útil do produto, ideia ou serviço.

Os enunciados anteriores (figura 11 e recorte 13) nos dão pistas da maneira como o discurso do novo e da novidade opera produzindo sentidos através do seu fundamento número 1 (só o que é novo, para a sociedade contemporânea, é bom). Uma das definições do substantivo automóvel é aquilo que contém em si mesmo os meios de propulsão; automotor, autopropulsor;

\footnotetext{
${ }^{91}$ Recuperado em 15 de março de 2015, de http://www.fiat.com.br/carros/novo-uno.html

${ }^{92}$ Sabemos que, para a Análise do Discurso, os efeitos de sentido podem sempre ser outros. A expressão "fundamento" é empregada como alicerce da ideologia dominante do novo e da novidade, que faz circular efeitos de sentido através da mídia na divulgação de produtos, ideias e serviços, em especial àqueles voltados para o consumo.
} 
pertencente a veículos ou máquinas que se propelem a si mesmos, tais como os veículos a motor. Sua função é a de transportar pessoas e objetos do ponto A para o ponto B. Simples assim, não fossem pelos vetores simbólicos que o automóvel adquiriu, ou seja, que foram construídos pelos discursos publicitários e midiáticos e assimilados pelo imaginário.

Conforme dissemos anteriormente, Edward Barnays percebeu que, ao invés de se dirigir ao senso prático dos consumidores (por exemplo, um veículo é um objeto usado para se deslocar do ponto A ao ponto B), a publicidade deve conter uma mensagem que transforma os produtos em vetores de sentido simbólico. O automóvel, por exemplo, deixa de ser apenas um meio de transporte de pessoas e objetos para se transformar em um símbolo de status, poder e afirmação social através de adjetivos que impulsionam a gama de atributos tecnológicos evidenciados em seus anúncios.

O que se envelhece não é, necessariamente, um amontoado de aço, alumínio, plástico, borracha e vidro de aproximadamente 1 tonelada e que ocupa um lugar significativo em nossas cidades, mas a ideia que cada sujeito faz desse objeto. Aqui vemos mais um dos fundamentos do discurso do novo e da novidade, o número 5 (o quanto a novidade é construída a despeito da vida útil do produto). Ao ser bombardeado pelos discursos publicitários dos novos veículos e seus atributos, a forma sujeito-consumidor tende a olhar para o seu objeto e, provavelmente, não mais enxergar os atributos simbólicos que haviam conquistado sua mente ao adquirir aquele objeto. Os efeitos do novo e da novidade compõem uma Formação Discursiva e ideológica presente no discurso midiático contemporâneo, e pode ser observado em enunciados sobre os mais diversos produtos, seja um automóvel, uma sandália ou um medicamento. Esse funcionamento discursivo também se reflete na questão das dietas e suas novidades fictícias, como veremos logo abaixo.

Uma vez que a Análise de Discurso atua nas relações dos sujeitos e na produção de sentidos, nos processos de identificação do sujeito, na argumentação, subjetivação e construção da realidade, buscamos compreender como a imagem resultante do discurso midiático do novo e da novidade cria uma memória contemporânea, que intervém concretamente no estabelecimento de uma forma de memória societal própria à nossa época e à nossa sociedade (Davallon, 2010, p. 32). À análise da memória discursiva ou interdiscurso na criação e reprodução do novo e da novidade soma-se a análise do que Orlandi (2010, p. 09) denomina “memória metálica", produzida pela mídia e pelas novas tecnologias de linguagem, uma memória da máquina, da circulação, que não se produz pela historicidade, mas por um constructo técnico. Uma memória que se forma na adição, no acúmulo, na repetição. Ao ser 
alicerçada basicamente na quantidade, e não na historicidade, a memória metálica é um dos arcabouços onde repousa o discurso do novo e suas repetições frenéticas e alucinantes.

É espantosa a quantidade de publicações voltadas especificamente para "boa forma" e "dietas", tanto nas versões impressas quando digitais, fazendo circular as novas dietas e afirmando e confirmando um padrão de beleza imaginário. Em um artigo sobre o site de busca "Google", as autoras consideram que as tecnologias, amplificadas pelo suporte eletrônico, instalam outros modos de produção, constituição e circulação dos sentidos, o que provocaria a necessidade de indagar sobre o sujeito discursivo, a interpelação ideológica e as movências de sentidos nos arquivos discursivos tramados na teia digital (Faria \& Romão, 2012, p. 01). Ao realizar uma busca por imagens nesse site, combinando as palavras "revista", "boa forma" e “dieta", uma infinidade de corpos-perfeitos irrompe na tela em questão de segundos ${ }^{93}$.

\footnotetext{
${ }^{93} \mathrm{~A}$ imagem em questão foi retirada de um sistema de busca na internet. Trata-se do resultado da junção das palavras "revistas" e "dietas". Recuperado em 10 de janeiro de 2018, de https://www.google.com.br/search?q=revistas+de+dietas\&biw=1366\&bih=643\&source=Inms\&tbm=isch\&sa=X \&ei=RtOSVMrBFoeJsQSI94H4DQ\&ved=0CAgQ_AUoAQ
} 


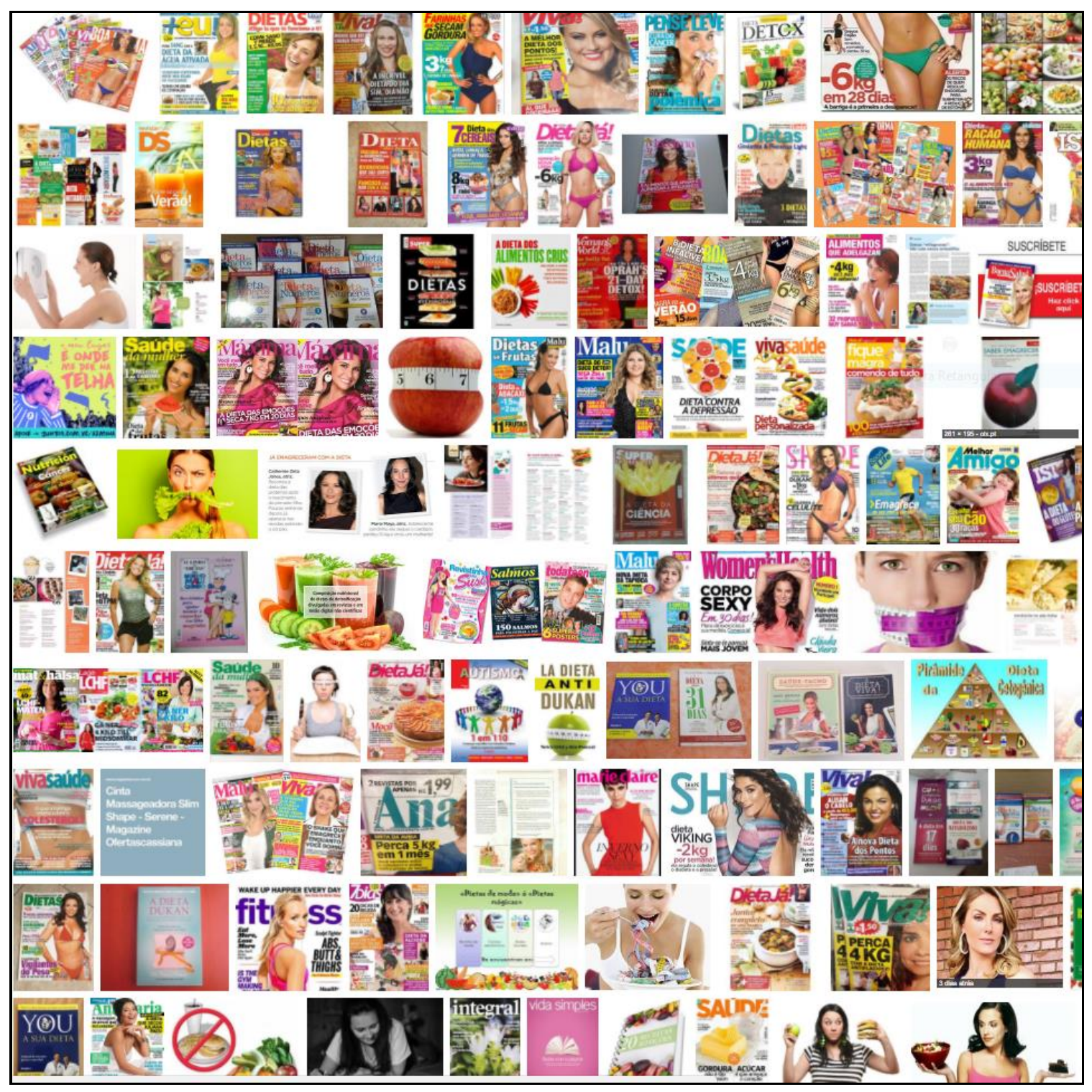

Figura 12

Nosso tempo revela uma cultura que não apenas consome muita informação, mas uma “cultura que se consome em informação" (Postman, 1994, p. 78). A informação aparece de forma indiscriminada, em enorme volume e em altas velocidades. Um dos meus cartunistas preferidos, André Dahmer alfineta os "novos tempos" ao satirizar o acesso indiscriminado ao excesso de informação: 

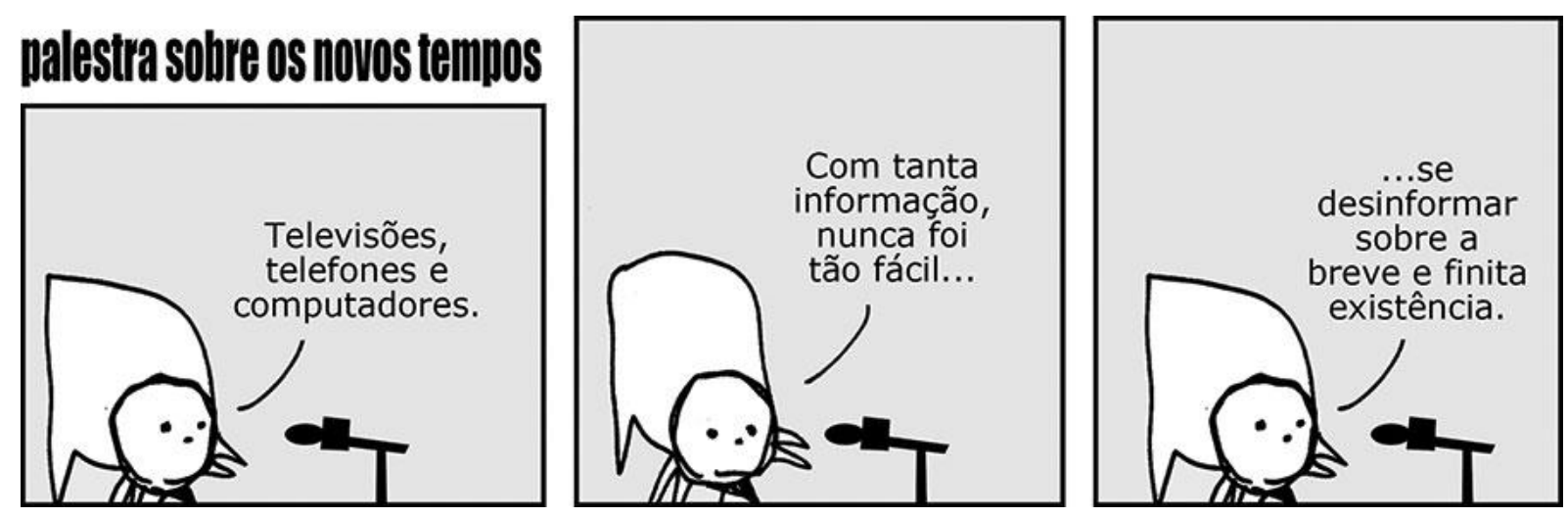

Figura 13. Cartum de André Dahmer (Folha de S. Paulo, 09/01/2015)

Consumimos o discurso do novo e da novidade em todas as suas maneiras: marcas, modas, grifes, tendências, atributos, adjetivos, figuras, ídolos, símbolos, ícones, logomarcas. E as consumimos cada vez mais em suportes eletrônicos. Temos o cinema, a televisão, o computador, os celulares, tablets, telas que se parecem com TVs nos ônibus, academias, ruas e lojas, com fins publicitários.

O discurso publicitário do novo pode ser observado em diversos produtos, desde cosméticos a produtos esportivos, de carros a remédios e, claro, dispositivos tecnológicos de criação e distribuição de imagens. Um site descreve um cosmético como um produto que possui “nova fórmula, nova embalagem e novos formatos". Na mesma página, outro produto é descrito como uma "uma nova linha com tecnologia MultiSphere", uma "novidade com microesferas extrafinas que disfarçam as imperfeições da pele" ${ }^{94}$. São vetores simbólicos que se destacam nos anúncios pelas maravilhas que oferecem aos seus consumidores, muitas vezes em uma linguagem de difícil acesso ao público, mas carregada de simbolismos, o que Gorz (2005) denomina "capital imaterial".

Para Pêcheux (2009, pp. 146-147), é a ideologia que, através do hábito e o uso, está designando, ao mesmo tempo, o que é o que deve ser, através de desvios linguisticamente marcados. É a ideologia que fornece as evidências com que uma palavra ou enunciado queiram dizer o que realmente dizem, porém mascaram o caráter material do sentido das palavras e dos enunciados. Isso ocorre, segundo ele, porque as palavras, expressões, proposições mudam de sentido segundo as posições sustentadas por aqueles que as emprega, adquirindo seu sentido em referências a essas posições, em referência às formações ideológicas. Estaria aí a Formação Discursiva (Pêcheux, 2009, p. 147), que determina o que pode e deve ser dito. As palavras,

\footnotetext{
${ }^{94}$ Recuperado em 20 de junho de 2016, de http://belezaesaude.com/novidade-cosmeticos-abr11/
} 
expressões, discursos, anúncios, publicidade e propaganda, informações jornalísticas, entre outras formas de produção e disseminação de informações, recebem seu sentido da Formação Discursiva na qual são produzidas. Assim ocorre com o discurso do novo e da novidade na divulgação das dietas e práticas de emagrecimento, um conjunto de mecanismos linguísticos que se constituem sócio-historicamente. Ao consumir as informações sobre as novas dietas e praticar o que elas propõem, o sujeito é interpelado pela Formação Discursiva dominante (no caso, só aquilo que é novo é bom), através da "identificação (do sujeito) com a formação discursiva que o domina (isto é, na qual ele é constituído como sujeito)" (Pêcheux, 2009, p. $150)$.

\subsection{A nova dieta: a escalada da obsolescência (do corpo)}

Uma vez que todo discurso se estabelece na relação com um discurso anterior e aponta para outro, a Análise de Discurso ajuda a compreender como uma determinada prática discursiva e, consequentemente, o seu discurso (no caso, o novo e a novidade) funciona produzindo efeitos de sentidos. Poderíamos dar inúmeros exemplos do discurso midiático do novo e da novidade (um deles é o universo automotivo - Sanches e Sousa, 2014). No presente trabalho vamos focar nossa análise do novo e da novidade no universo das dietas. Para tentar compreender como esse mecanismo de produção e circulação do novo funciona, definimos como corpus o discurso do universo das dietas presentes nas revistas e sites que compõem nosso trabalho de pesquisa, observando a construção, estruturação, circulação e os diferentes gestos de leitura que constituem os recortes submetidos à análise.

Através da Análise do Discurso, buscamos compreender o modo de funcionamento desse discurso no lançamento de novos regimes, amplificado pela velocidade de criação e disseminação de notícias caracterizada pelo suporte eletrônico, que instaura outros modos de produção, constituição e circulação de informações.

O permanente diálogo entre máquinas e pessoas que configura o mundo online e a instantaneidade do espaço virtual configuram aspectos fundamentais para a criação e circulação do discurso das novas dietas e suas supostas novidades. O que se procura envelhecer, no entanto, são os próprios vetores simbólicos presentes no discurso do lançamento de um determinado produto, ideia ou serviço. Aquilo que foi divulgado como sendo a última novidade, 
a mais recente tecnologia, em pouco tempo é substituído por outros atributos, que torna aquilo que era novidade em algo velho e ultrapassado, em um moto-contínuo (Sanches e Sousa, 2014).

Foxcroft (2013, p. 41) alerta que atualmente há sempre um novo manual de dieta nas listas de livros mais vendidos, e muitos deles promovem regimes insustentáveis ou versões requentadas de modismos anteriores, com frequência endossados por alguma celebridade cujo corpo inatingivelmente esbelto denuncia horas de trabalho e um bocado de investimento financeiro. A cada edição das revistas de boa forma, uma infinidade de novidades faz circular sentidos que exaltam a velocidade/imediatismo para emagrecer (que veremos mais adiante), a facilidade (a suposta possibilidade de emagrecer com receitas rápidas e fáceis ou exercícios que podem ser praticados no ambiente de trabalho), entre outros aspectos. Foxcroft (2013) argumenta que as novas dietas são tentadoras ao prometerem uma perda de peso livre de tensões, indolor e de forma imediata. Quando, de fato, fazer dieta é um processo muito mais complexo do que a mídia faz parecer. "Toda indústria das dietas investiu no pensamento mágico e na novidade e explora o lucrativo negócio de vender esperança a infelizes e desesperados e criar um círculo vicioso de desesperança" (Foxcroft, 2013, p. 22).

São inúmeros os exemplos do novo e da novidade no universo das dietas. As próprias dietas anunciadas como novas são, em muitos casos, reedições de versões anteriores. "Novas dietas vão e vêm, mas sempre são reelaborações do passado, e o mesmo é válido para alguns dos produtos mais bizarros no mercado do emagrecimento" (Foxcroft, 2013, p. 239). Como dissemos no início desta pesquisa, provavelmente o sujeito que está sentado ao seu lado no ambiente de trabalho fez ou está fazendo algum tipo de dieta; alguém da sua família fez ou está experimentando algo para emagrecer.

No capítulo 3, empreendemos uma análise sobre os nomes próprias das dietas e seus efeitos de sentidos. Ao acrescentar aos substantivos (nomes) das dietas os adjetivos novo, nova ou novidade, a lista de denominações empregadas pelo texto midiático das dietas e boa forma para bombardear o sujeito com informações sobre dietas cresce exponencialmente. Aqui observamos uma das contradições atreladas à FD do corpo-projeto: fazer dieta é um processo muito mais complexo do que a mídia faz parecer. Cada dieta é lançada como uma "novidade" ou, em outras palavras, com um "diferencial”. Vejamos alguns exemplos:

\section{Recorte 14:}

É moda na Europa! Nova dieta alterna minijejum com dias de até $1.500 \mathrm{kcal}^{95}$

\footnotetext{
${ }^{95}$ Chamada de capa da revista Dieta Já! (edição n. 246).
} 
SUPER NOVIDADE! DIETA NÓRDICA. - $4 \mathrm{~kg}$ em um mês. Copie o prato das mulheres + magras do mundo ${ }^{96}$

Novas fórmulas para emagrecer ${ }^{97}$

Dieta nórdica: nova forma saudável de perder peso $^{98}$

A nova Dieta Dukan é mais fácil e tão eficiente quanto a original ${ }^{99}$

A nova dieta que é febre entre as famosas ${ }^{100}$

Nutricionista revela nova dieta da Bruna Marquezine ${ }^{101}$

O novo jejum para emagrecer. A dieta em circuito vai fazer você perder peso sem sofrimento ${ }^{102}$

Esses recortes nos dão pistas da maneira como o discurso do novo e da novidade opera produzindo sentidos através do seu fundamento número 1 (só o que é novo, para a sociedade contemporânea, é bom). Pelo simples fato de ser (aparentar ser) uma novidade, as novas dietas apresentam-se como milagres na busca pelo emagrecimento, prometendo fórmulas mágicas de se alcançar o corpo perfeito. Elas são sempre mais fáceis e eficientes que suas coirmãs mais antigas: "A nova dieta Dukan é mais fácil e tão eficiente quanto a original”. O discurso do novo e da novidade das dietas faz circular efeitos de sentidos de facilidade, rapidez, eficiência, em muitos casos atreladas às celebridades, em uma escalada da obsolescência (sempre há uma nova dieta prometendo suplantar as anteriores).

A "nova dieta Dukan" do recorte acima foi publicada no site mdemulher.abril.com.br em 6 de abril de 2015 (atualizado em 13 de abril do mesmo ano), e gerou o seguinte comentário de um sujeito-leitor:

\section{Recorte 15:}

Estou na fase cruzeiro da ducan original, será que posso mudar para nova dieta ducan? ${ }^{103}$

Oito meses antes, a edição de agosto de 2014 da revista Shape trazia em sua capa:

\footnotetext{
${ }^{96}$ Chamada de capa da revista Corpo a Corpo (edição n. 315).

${ }_{97}$ Matéria da revista Shape (edição n. 67, p. 52).

${ }^{98}$ Recuperado em 1 de dezembro de 2015, de http://mdemulher.abril.com.br/dieta/claudia/dieta-nordica-novaforma-saudavel-de-perder-peso

99 Recuperado em 1 de dezembro de 2015, de http://mdemulher.abril.com.br/dieta/boa-forma/a-nova-dietadukan-e-mais-facil-e-tao-eficiente-quanto-a-original

${ }^{100}$ Recuperado em 1 de dezembro de 2015, de http://mdemulher.abril.com.br/famosos-e-tv/boa-forma/a-novadieta-que-e-febre-entre-as-famosas

101 Recuperado em 1 de dezembro de 2015, de http://corpoacorpo.uol.com.br/dieta/dieta/dieta-dasfamosas/nutricionista-revela-nova-dieta-da-bruna-marquezine/8334

102 Matéria da revista Boa Forma (edição n. 349, p. 6).

${ }^{103}$ Recuperado em 1 de dezembro de 2015, de http://mdemulher.abril.com.br/dieta/boa-forma/a-nova-dietadukan-e-mais-facil-e-tao-eficiente-quanto-a-original
} 


\section{Recorte 16:}

EXCLUSIVO! Nova dieta DUKAN! - $1 \mathrm{~kg}$ por semana! (mais fácil de seguir! $)^{104}$

O sujeito-leitor que se apoia no discurso midiático das dietas para tentar emagrecer, sendo interpelado pela ideologia da magreza e atreladas às Formações Discursivas das dietas e do corpo-projeto, provavelmente faz um esforço para acompanhar tantas novidades. São inúmeros os exemplos do novo e da novidade no discurso das dietas. As próprias dietas anunciadas como novas são, em muitos casos, reedições de versões anteriores. "Novas dietas vão e vêm, mas sempre são reelaborações do passado, e o mesmo é válido para alguns dos produtos mais bizarros no mercado do emagrecimento" (Foxcroft, 2013, p. 239). Outros efeitos de sentidos também podem ser percebidos nos enunciados acima, evocando, por exemplo: 1 . Superioridade, alto grau de sofisticação (atrelar a novidade a um país ou continente supostamente mais desenvolvido que o nosso, como supernovidade nórdica ou a moda europeia da alternância de jejum e ingestão de um número específico de calorias); 2. Velocidade, rapidez, imediatismo (- 4 kg em um mês); 3. Comparação (ao sugerir que as mulheres mais magras do mundo são as nórdicas, e não as brasileiras); 4. Modismos (a nova dieta é febre entre as famosas, sempre magras, com seus corpos perfeitos); 5. Facilidade (A nova Dieta Dukan é mais fácil e tão eficiente quanto a original).

Os efeitos atrelados ao discurso midiático das dietas marcam o processo de emagrecer como algo fácil de fazer e rápido na geração de resultados. Segundo Foxcroft (2011, p.18), "fazer regime é um processo no qual a pessoa embarca carregada de emoções, muitas vezes com uma postura de autoflagelação, e o empreendimento todo é temperado com o potencial para o fracasso". Os recortes 15 e 16 também indiciam o modo como o sujeito-leitor parece ser arremessado de um lado para outro pelas ondas das novidades do oceano midiático das dietas. O sujeito do discurso das dietas, que "surfa nas ondas" do novo e da novidade, é o sujeito, que segundo Bauman, se não quiser afundar, está sempre surfando:

O truque é manter o ritmo com as ondas. Se não quiser afundar, mantenha-se surfando - e isso significa mudar o guarda-roupa, o mobiliário, o papel de parede, o olhar, os hábitos, em suma, você mesmo, quantas vezes puder. Eu não precisaria acrescentar, uma vez que isso deva ser óbvio, que essa ênfase em eliminar as coisas - abandonando-as, livrando-se delas -, mais que sua apropriação, ajusta-se bem à lógica de uma economia orientada para o consumidor. Ter pessoas que se fixem em roupas, computadores, móveis ou cosméticos de ontem seria desastroso para a economia, cuja principal

${ }^{104}$ Chamada de capa da revista Shape (edição n. 60). 
preocupação, e cuja condição sine qua non de sobrevivência, é uma rápida aceleração de produtos comprados e vendidos, em que a rápida eliminação dos resíduos se tornou a vanguarda da indústria ${ }^{105}$ (grifos nossos) (Oliveira, 2012).

Bauman (1998) nos diz que o que vemos na sociedade atual é um processo de "mercadorização", no qual ocorre simultaneamente o ato de nascimento do consumidor: mercadorias potenciais e compradores potenciais realizam-se juntos. Assim também ocorre com as dietas: há um entrelaçamento do sujeito-leitor com as dietas, não as de ontem ou de anteontem ou do mês passado, mas as novas dietas, aqueles que estampam a edição mais atual da revista ou site de boa forma. "Surfar nas ondas" das novidades instituídas pelo discurso midiático é uma necessidade das massas contemporâneas. Provavelmente as celebridades que endossam as dietas da moda possuem um arsenal de profissionais (nutricionistas, preparadores físicos, médicos, entre outros) muito bem remunerados e que não estão ao alcance da maioria da população para manter seus corpos perfeitos (sem falar na manipulação digital empregada na construção das imagens midiáticas do corpo-projeto). O novo também aparece nas diversas práticas de emagrecimento, como a alimentação:

\section{Recorte 17:}

Novos superalimentos sem glúten! ${ }^{106}$

Tomate no jantar queima calorias [...] Adote esse novo hábito e perca $3 \mathrm{~kg}$ em um mês ${ }^{107}$

O novo chá aliado da dieta ${ }^{108}$

Refeições com calorias negativas. Elas são a nova escolha dos nutricionistas para emagrecer de forma rápida ${ }^{109}$

Ataque às últimas gordurinhas. Firme na dieta? Para dar um novo impulso à perda de peso, o cardápio começa com uma semana detox ${ }^{110}$

Outros exemplos da novidade são os aparelhos, aplicativos ou procedimentos estéticos para emagrecer:

\section{Recorte 18:}

\footnotetext{
${ }^{105}$ Recuperado em 13 de outubro de 2013, de http://revistacult.uol.com.br/home/2010/03/entrevis-zygmuntbauman/

${ }^{106}$ Chamada de capa da revista Shape (edição n. 68).

107 Chamada de capa da revista Dieta Já! (edição n. 242).

108 Recuperado em 1 de dezembro de 2015, de http://mdemulher.abril.com.br/dieta/boa-forma/o-novo-chaaliado-da-dieta

${ }^{109}$ Matéria da revista Dieta Já! ((edição n. 235, p. 28).

110 Matéria da revista Boa Forma (edição n. 350, p. 44).
} 
Especial beleza: 10 Supernovidades para Rosto e Corpo (a Ciência Comprova) $)^{111}$

PROJETO ANTIPNEUS [...] Novos aparelhos que derretem a gordurinha ${ }^{112}$

Novo aplicativo Atitude Boa Forma. O aliado perfeito para o seu projeto de vida saudável ${ }^{113}$

Conheça os 4 novos métodos para emagrecer

Novo programa oferece detox de sete dias para acelerar o emagrecimento ${ }^{114}$

As novas pílulas naturais para emagrecer ${ }^{115}$

Novas proteínas para emagrecer. Saia da mesmice com a inclusão de duas carnes diferentes na rotina ${ }^{116}$

Dê folga para a esteira! A nova aeróbica pode ser feita em casa, na praia, na rua, na praça... e queima 700 calorias ${ }^{117}$

Os efeitos de sentidos do discurso midiático das dietas, atrelada à Formação Discursiva da dieta enquanto procedimento ligado estritamente à perda de peso, são potencializados por recursos linguísticos como "detox", "superalimentos", "supernovidades", "projeto antipneus" e tantas outras expressões que, como dissemos anteriormente, permitem entrever sua veia publicitária.

No dicionário Michaelis de Língua Portuguesa, uma das definições para o adjetivo novo é "[aquilo] que tem pouco uso". No entanto, inúmeros produtos tornam-se obsoletos antes de perderem sua razão de uso, ou seja, não porque deixaram de funcionar adequadamente ou não realizam mais a função a que se destinam pelo desgaste natural de seus componentes, mas sim pelo envelhecimento imaginário imposto pelo discurso publicitário/midiático. "Sempre sinto um cheiro de mesquinharia quando ouço alguém falar de uma nova dieta", alfineta o jornalista e escritor Luiz Felipe Pondé (2014). As dietas, assim como os produtos, tornam-se obsoletas rapidamente por serem suplantadas por outra grande ideia para emagrecer.

Outro aspecto contraditório que chama nossa atenção no discurso midiático das dietas é a forma sujeito corpo-(re)fabricado, que faz parecer natural um processo de renovação do corpo (contrário ao processo natural de envelhecimento), mantendo-o sempre esbelto e jovem, como se fosse possível estancar as marcas que o tempo imprime ao sujeito. Não é para menos que

\footnotetext{
${ }^{111}$ Chamada de capa da revista Women's Health (edição n. 79). No texto da matéria, algumas das novidades são destinadas a "enxugar gordura" ou denominadas "seca-culote", proporcionando um "corpo firme e desenhado". 112 Chamada de capa da revista Boa Forma (edição n. 343).

${ }^{113}$ Anúncio da revista Boa Forma (edição n. 347, p. 113).

${ }^{114}$ Recuperado em 1 de dezembro de 2015, de http://corpoacorpo.uol.com.br/dieta/dieta-de-emergencia/novoprograma-oferece-detox-de-sete-dias-para-acelerar-o-emagrecimento/9756

115 Recuperado em 1 de dezembro de 2015, de https://boaforma.abril.com.br/dieta/as-novas-pilulas-naturaispara-emagrecer/

${ }^{116}$ Matéria da revista Corpo a Corpo (edição n. 317, p. 70).

${ }^{117}$ Chamada de capa da revista Corpo a Corpo (edição n. 319).
} 
uma campanha publicitária de uma grande fabricante mundial de cosméticos, com a atriz britânica Kate Winslet, é enfática ao explorar o envelhecimento feminino:

\section{LANCÔME}

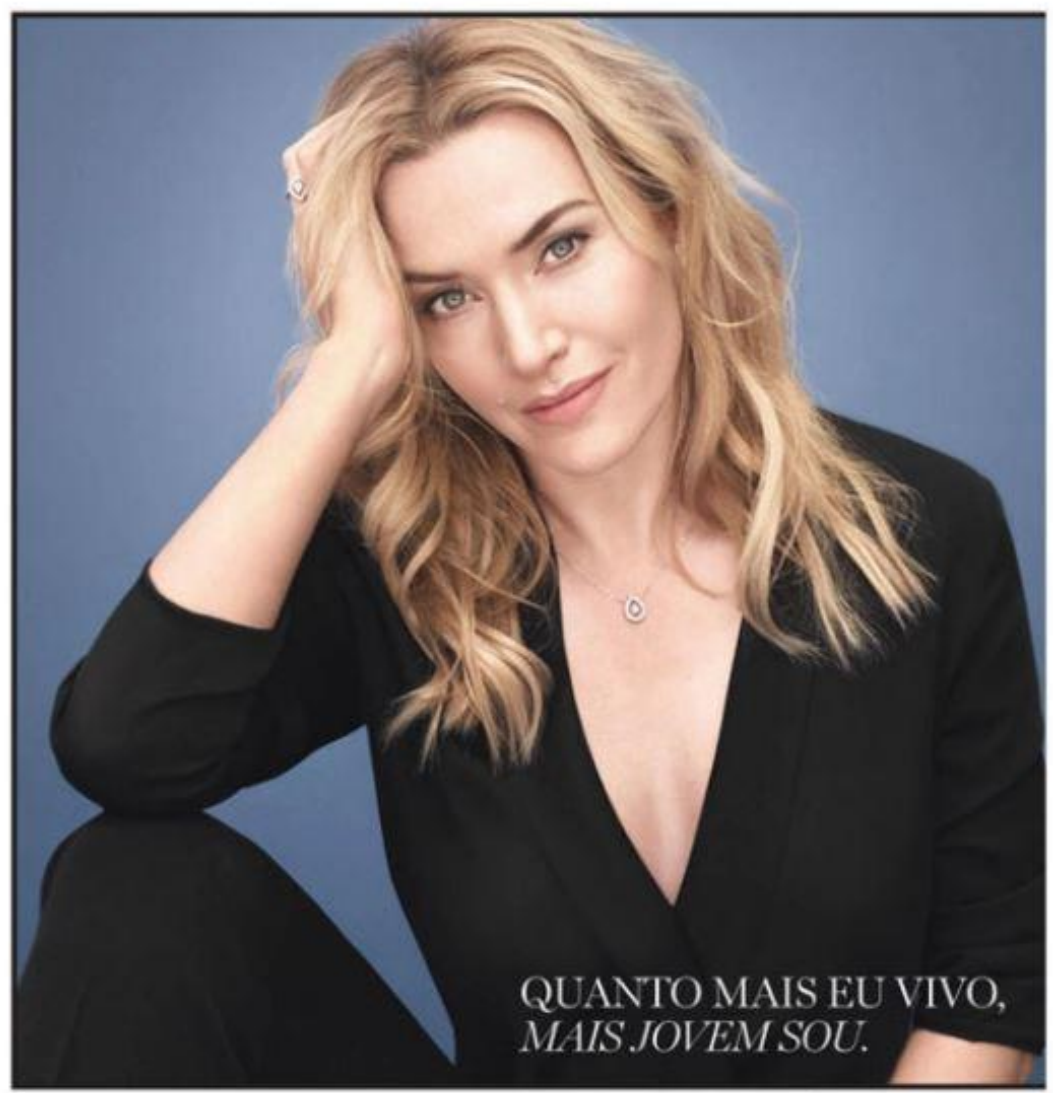

ADVANCED GÉNIFIQUE

Figura 14. Campanha protagonizada pela atriz Kate Winslet ${ }^{118}$

O contrassenso é explícito, mas funciona: ninguém quer envelhecer. No fundo, todos querem ter uma vida longa, mas não querem sofrer a ação do tempo. Principalmente as mulheres. Daí a publicidade funcionar discursivamente ao irromper efeitos de juventude para vender produtos destinados ao público feminino, prometendo estancar o envelhecimento corporal. Os efeitos de sentido exploram o medo do envelhecer e suas consequências (falaremos mais sobre o medo no próximo capítulo). Ao invés de aparentar mais idade, o discurso do corpo-

\footnotetext{
118 Recuperado em 13 de janeiro de 2018, de https://mcdn.belezanaweb.com.br/image/upload/f_auto,fl_progressive,q_auto:best,w_800/v1/imagens/5/345 42-complementar-1-4396103653025533742.jpg
} 
sempre-jovem ancora simbolicamente o envelhecimento ao inverter a lógica temporal. Além das dietas ou objetos que devem ser sempre novos, o corpo deve submeter-se a qualquer recurso disponível para se manter sempre "novo". Não há espaço para o "corpo-velho", de aspecto enrugado. A ideologia do "corpo-sempre-jovem" materializa-se na linguagem midiática da forma sujeito "corpo-renovado", que não pode envelhecer, não pode apresentar rugas, sinais de cansaço, olheiras, marcas do tempo, como podemos ver nos próximos recortes:

\section{Recorte 19:}

Corpo novo a partir de $\mathrm{R} \$ 85$. Ataque a celulite, gordura, estrias... ${ }^{119}$

Seu rosto pede uma pele nova ${ }^{120}$

Ano novo, corpo novo. Não espere o carnaval passar para começar o ano de verdade $^{121}$

Jovem para sempre. O cardápio que previne e combate cabelos brancos e linhas de expressão (de quebra, seca $5 \mathrm{~kg}$ em 1 mês!) ${ }^{122}$

Fernanda Lima. As novas estratégias dela para manter este corpão aos 38 $\operatorname{anos}^{123}$

Corpo novo com crossfit. A atriz portuguesa Rita Pereira, garota da capa deste mês, mostra o treino express que lapidou suas formas ${ }^{124}$

A ideologia do corpo-projeto interpela o sujeito-leitor de modo a não deixar espaço para a circulação de vários sentidos sobre o seu próprio corpo: deve ser magro, e não gordo; deve ser rápido e ágil, e não devagar ou desajeitado; deve ser belo, e não feio; deve ter sempre um aspecto jovem, nunca velho. A empatia com a velhice e o envelhecimento encontra uma série de barreiras, atesta Norbert Elias (2001), pois consciente ou inconscientemente resistimos à ideia do próprio envelhecimento e da morte. A atriz Marisa Orth confessou: "Obviamente gente mais bonita tende a pegar mais trabalho. Mesmo a atriz mais velha, se estiver mais magra, vai pegar mais trabalho. A gente tem que ter um compromisso com a magreza, com a saúde. Você tem que estar com um corpo wearable"125.

Ao mesmo tempo que ressoa efeitos de sentidos sobre o formato do corpo, privilegiando determinados aspectos e apagando tantos outros, a ideologia do corpo-projeto promove um embate entre aquilo que é da ordem do singular e do geral. Se, de um lado, o corpo deve ser

\footnotetext{
${ }^{119}$ Chamada de capa da revista Shape (edição n. 69).

120 Matéria da revista Boa Forma (edição n. 345, p. 82).

${ }^{121}$ Matéria da revista Women's Health (edição n.86, p. 72).

${ }^{122}$ Chamada de capa da revista Corpo a Corpo (edição n. 319).

${ }^{123}$ Chamada de capa da revista Boa Forma (edição n. 349).

${ }^{124}$ Matéria da revista Women's Health (edição n.80, p. 7).

125 Recuperado em 29 de junho de 2016, de http://www1.folha.uol.com.br/serafina/2016/06/1775332-famosapelo-humor-marisa-orth-encara-personagem-triste-em-novela.shtml
} 
magro, de outro, o formato de suas partes está em contínua mutação. Ademais, as fórmulas para alcançar o corpo-projeto são frequentemente alteradas. O corpo-projeto, como o próprio nome indica, é um protótipo de formato corporal, cujas feições são modificadas de acordo com os modismos (como veremos mais adiante, nos recortes 31 e 32). É um plano, um empreendimento a ser realizado, um esboço que, no discurso das dietas, nunca é ou será finalizado. Conforme visto anteriormente, Pêcheux reforça que há um conjunto de mecanismos que atua entre a objetividade dos fatos e a subjetividade das experiências. Contudo, "a subjetividade não se situa no campo individual, mas no de todos os processos de produção social e material", reforça Gregolin (2007, p. 21). "Há uma permanente tensão entre a produção de kits de subjetividade e a criação de singularidades", explica a pesquisadora. Isso pode ser observado nos efeitos de sentidos do discurso das dietas de dois modos. Primeiro, o discurso faz ressoar efeitos de exclusividade, singularidade: afine, apaixone-se, aproveite, ataque (celulite, estrias, gorduras), conquiste, copie, elimine, faça, perca (peso), realize, vai que dá!, você consegue, você pode; para ficar em alguns exemplos. $\mathrm{O}$ discurso parece ser dirigido a uma única pessoa, quando sabemos que não se destina a um único sujeito, a uma mulher em especial, mas ao público feminino em geral.

O segundo aspecto está no princípio do discurso do novo e da novidade. Se as linhas corporais e as fórmulas ou métodos para esculpir o corpo são sempre atualizadas apresentadas como novas, isso exige do sujeito uma atualização constante, um contínuo (re)fazer de si mesmo. O sujeito da atualidade habita um mundo sem chão, um barco chacoalhado pela força das ondas e de tempestades que não têm fim. As condições de existência mudam repentinamente, gerando um "mal-estar contemporâneo", fruto da "tensão entre uma desestabilização acelerada e a persistência da referência identitária” (Gregolin, 2007, p. 21 grifos nossos).

Nos recortes acima, percebemos como o sujeito-leitor é interpelado a se inscrever em uma Formação Discursiva de renovação do corpo - tudo aquilo que remete ao processo natural de envelhecimento deve ser submetido a ações de rejuvenescimento. Outros efeitos atrelados à FD das dietas e do "corpo-renovado" apontam para um processo sempre disponível e que não exige muitos gastos. Um exemplo é a chamada de capa "Corpo novo a partir de R\$ 85", o que remete a efeitos de que o corpo é algo descartável, que pode ser comprado no balcão de uma clínica de estética por um preço acessível. Quando sabemos que os procedimentos estéticos são relativamente custosos e a indústria da dieta explora um lucrativo negócio (Foxcroft, 2014). “Ano novo, corpo novo" e "Corpo novo, vida nova” também são expressões publicitárias (e não jornalísticas) que remetem a efeitos de renovar, substituir algo velho por um sistema novo, 
rejuvenescido. O discurso do corpo renovado está presente na venda de livros, um importante nicho do mercado editorial brasileiro ${ }^{126}$ :

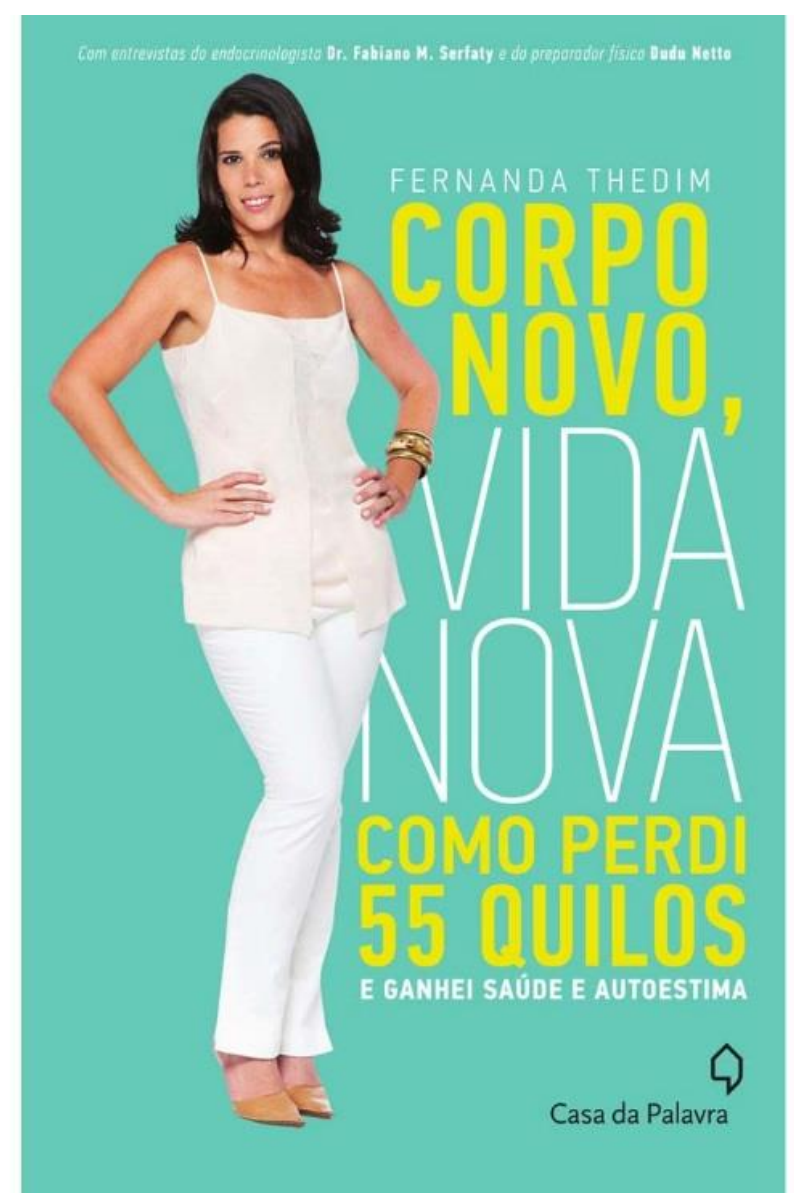

Figura $15^{127}$

No entanto, ao insistir no efeito de renovação do corpo, o discurso midiático apaga o processo de envelhecimento natural desse mesmo corpo, fazendo desaparecer a sua obsolescência, mantendo uma busca insaciável por produtos e regimes que permitam ao sujeito ser "jovem para sempre". As marcas da pele e suas linhas de expressão (estrias, celulite, manchas, cicatrizes) devem ser combatidas, assim como os cabelos brancos. Não importa a

\footnotetext{
${ }^{126} \mathrm{Em}$ 2014, um dos livros mais vendidos atualmente no país segundo uma revista de grande circulação era “Eu não consigo emagrecer", escrito pelo médico francês Pierre Dukan. A obra figurava há 81 semanas entre os 10 livros mais vendidos na categoria "Autoajuda e Esoterismo". Recuperado em 6 de maio de 2014, de http://veja.abril.com.br/livros_mais_vendidos/

127 Recuperado em 2 de julho de 2016, de
https://www.google.com. $\mathrm{br} /$ search?q=corpo+novo+vida+nova+livro\&espv=2\&source=Inms\&tbm=isch\&sa=X\&v ed=0ahUKEwiD6e2zmdXNAhXGF5AKHQJJAR4Q_AUICSgC\&biw=1366\&bih=643\#imgrc=AS6IwjlfS4nxeM\%3A
} 
idade: os métodos para manter-se sempre jovem e, portanto, "atualizado", estão à disposição do sujeito. No discurso midiático das novas dietas não há espaço para outros dizeres: um corpo ostentando marcas do tempo ou acima do peso possuem pouco ou quase nenhum espaço nas revistas ou sites de boa forma.

A velocidade imposta pelo discurso do novo e da novidade corrói o tempo, tornando produtos (e os discursos que os validam e os legitimam) rapidamente obsoletos, alimentando a necessidade de mais novidades em um ritmo frenético (Sanches e Sousa, 2014). A necessidade de envelhecer coisas e conceitos faz parte de uma lógica do capitalismo para vender cada vez mais: mais revistas, mais visualizações nos sites, mais produtos e procedimentos estéticos, mais cirurgias estéticas, mais alimentos "funcionais" que prometem saciar a fome sem engordar. Mais, mais e mais: é a lógica a que está submetido a forma histórica sujeito-capitalista. A ideologia do mercado cria uma realidade midiática que acelera o tempo e envelhece coisas (palpáveis e não palpáveis), que muitas vezes são descartadas para dar lugar ao último lançamento, aquilo que é mais recente, em uma lógica do capitalismo e do consumo (Sanches e Sousa, 2014). Esse discurso usa uma linguagem sempre ancorada em simbolismos, promessas de que o novo (a nova dieta, o novo aparelho para eliminar gorduras ou o novo exercício) por si só, é e será sempre o melhor, mesmo que o surgimento de coisas novas ocorra numa velocidade incompatível com a capacidade dos sujeitos de consumi-las e entendê-las em sua totalidade.).

\subsection{A velocidade da novidade: o sujeito-voraz}

Aproveitar o tempo! Mas o que é o tempo, para que eu o aproveite? Fernando Pessoa

A velocidade com que algo novo (um dispositivo ou uma informação) surge é compatível com a nossa capacidade de absorver a novidade? Conseguimos lidar com a rapidez com que os produtos (e seus discursos) são produzidos e descartados? Quantas dietas que se auto proclamam novas são lançadas em um curto espaço de tempo? A que velocidade circula a informação hoje? questiona o jornalista e professor Ignacio Ramonet (2003). Ele próprio responde: “À velocidade da luz, ou seja, 300 mil quilômetros por segundo. Passamos de um mundo do jornalismo para um mundo do imediatismo, do instantaneísmo, não há tempo para 
estudar a informação. A informação é feita cada vez mais de impressões, de sensações" (Ramonet, 2003, p. 247).

A velocidade circulatória de informações ocorre em um contexto tipicamente contemporâneo, conforme aponta Bethania Mariani (2009) ao enfatizar que o que rege a maioria das relações sociais na atualidade é uma submissão à circulação da mercadoria, uma circulação volátil e em movimento rápido e constante. O cartum abaixo ironiza a velocidade com que os produtos tecnológicos se tornam obsoletos:

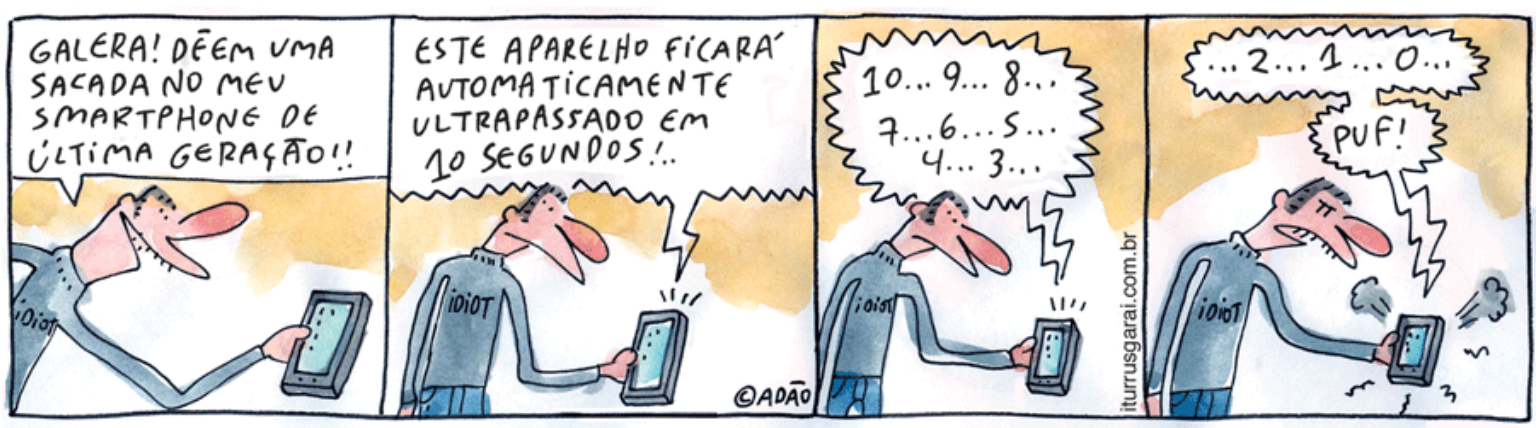

Figura 16. Cartum de Adão Iturrusgarai (Folha de S. Paulo, 19/08/2013)

O discurso publicitário do novo trabalha a serviço do mercado, é por ele gerado e serve de base para a venda de produtos e ideias. A velocidade com que tais produtos (e seus discursos) são criados e recriados faz parte de uma prática mercadológica que encontra um meio ambiente favorável para se expandir nos dias atuais em razão das tecnologias de comunicação e informação (ambiência midiática). Velocidade é um conceito-chave para se entender o que está em jogo nesse processo: “Global mesmo é a medida de velocidade de deslocamento de capitais e informações, tornados possíveis pelas teletecnologias", garante Sodré (2003, pp. 24-25).

A velocidade imposta pelo discurso do novo e da novidade corrói o tempo, tornando produtos (e os discursos que os validam e os legitimam) rapidamente obsoletos, alimentando a necessidade de mais novidades em um ritmo frenético. Como vimos em recortes anteriores, o discurso midiático das dietas funciona sob a mesma lógica: novas dietas são criadas e recriadas em uma velocidade estonteante. É a lógica do capitalismo e do consumo.

É essa realidade (linguística e midiática) que se mostra constitutiva do discurso das dietas, "um real constitutivamente estranho à univocidade lógica e um saber que não se transmite, não se aprende, não se ensina e que, no entanto, existe produzindo efeitos", (Pêcheux, 2009). 
O discurso do novo e da novidade produz sentido de pertencimento ao configurar discursivamente o funcionamento social em função dos vetores mercadológicos e tecnológicos de produtos e serviços. Mas como isso ocorre? O aparecimento de novos dispositivos tecnológicos demanda do sujeito atual o domínio de novas e múltiplas linguagens, o que também demanda, segundo Payer (2015), uma nova forma de sujeito apto a dominar essa multiplicidade comunicativa. "Um sujeito capaz de tudo dizer, tudo compreender, de muitos modos, de controlar com sua vontade os efeitos de sentido do seu discurso, de um modo implacavelmente "eficaz" (Payer, 2015, p. 13). Se o sujeito não faz os investimentos necessários para alcançar o sucesso difundido pela mídia (como vimos anteriormente), ele não pertence - no sentido de não fazer parte do mercado de trabalho, não pertencer aos grupos sociais (mesmo que cada vez mais virtuais), não consegue inserir-se e acompanhar o mundo a sua volta. A forma sujeito-consumidor-capitalista é a forma sujeito-voraz: "que tudo quer fazer, tudo quer saber, tudo quer ter, tudo quer ver, tudo quer... tudo quer..., na crença ilusória de que um dia vai atingir a plenitude suposta no sucesso", (Payer, 2015, p. 20). O modo de existir do sujeito-voraz exige de si próprio uma adequação à velocidade da instantaneidade, interatividade e urgência, colocando o corpo em estado de alerta, um efeito naturalizado de que o corpo não pode parar, sendo impelido reiteradamente a digitar, dizer, navegar (Gallo \& Romão, 2011, p. 14). Na trilha desse pensamento, podemos inferir que o sujeito-voraz é impulsionado pelo texto midiático das dietas e boa forma nunca parar de correr, emagrecer, conhecer novos produtos, praticar novas modalidades de regime.

São vários os exemplos de discurso contemporâneo sobre o novo, a novidade e, de acordo com as empresas que os fabricam, seus benefícios são inúmeros. Tais discursos são empregados principalmente nas imagens publicitárias, difundidas em uma velocidade jamais vista em diversos dispositivos e telas. "Trata-se da alienação do homem em relação aos seus próprios instrumentos", critica Flusser (2002, p. 09) ao analisar a relação do sujeito contemporâneo com as imagens. Não somos contra o progresso e seus benefícios. Mas, como diz Postman (1994, p. 78), vivemos em um mundo no qual a ideia de progresso humano, "como Bacon expressou, foi substituída pela ideia de progresso tecnológico. A meta não é reduzir a ignorância, a superstição e o sofrimento, mas sim ajustar-nos às exigências das novas tecnologias". Retomemos a reflexão proposta por Cristiane Dias (2012, p. 44): para compreender o corpo significado pela tecnologia (estendendo o conceito de tecnologia para além dos equipamentos técnicos), é primordial esquadrinhar "o modo de inscrição do corpo e do sentido da própria vida social no interstício do planeta”. 
As novas tecnologias são sedentas em produzir o novo, a novidade, outros dispositivos, informações, novas formas de se fazer coisas antigas, novos modelos de comunicação, um mundo sem fim de novidades. Não nos referimos unicamente aos produtos tecnológicos, mas a toda ideia ou informação que recorre à tecnologia como aquilo que serve de base para o desenvolvimento e produção de algo novo (seja um novo medicamento, um cosmético ou um tênis destinado àqueles que pretendem correr mais rápido de forma mais confortável). Postman (1994) chama esse estado de coisas, essa rendição à cultura tecnológica e suas ramificações na sociedade (aqui se insere o discurso do novo), como tecnopólio. Segundo ele, não se trata apenas de um estado de cultura, mas um estado de mente. Para Kamper (2016), trata-se de uma tecnoteologia, uma religião de maquinadores.

Romão (2004, p. 74) traz à tona um outro aspecto deste cenário tecnológico: seria "leviano afirmar que todos os cidadãos do mundo estão submetidos igualmente ao mesmo banho de tecnologia; que eles têm as mesmas chances de instalação na rede e tomam a mesma ducha de virtualidade". É uma ressalva concernente, dado que nem todos têm igual acesso aos serviços oferecidos pela sociedade digital. Contudo, na tentativa de desbravar os efeitos do texto midiático das dietas e boa forma, nossa investigação incide sobre a forma sujeito-conectado. Um sujeito que, ao "surfar nas ondas" das novidades tecnológicas, está convencido de que o "progresso técnico é a realização suprema da humanidade e o instrumento com o qual podem ser solucionados nossos dilemas mais profundos” (Postman, 1994, p. 79). Ao analisar o computador enquanto ferramenta de devoção da cultura contemporânea (análise que pode ser estendida a todos os dispositivos de geração e disseminação de informação) Postman (1994) diz que os problemas mais sérios que confrontamos, tanto na esfera pessoal como na pública, requerem soluções técnicas por meio do acesso rápido à informação que, de outra maneira, seria inacessível. Aqui podemos acrescentar o acesso à informação mais recente, aquela que traz a última novidade, o último medicamento, a dieta mais recente, o cosmético mais novo que, imbuído da mais recente tecnologia, acabará com todas as nossas rugas. 


\section{Capítulo 5}

A ICONOGRAFIA DAS DIETAS: GEOMETRIZAÇÃO DO CORPO E EFEITOS DE COMPLETUDE (CORRA PARA SEMPRE)

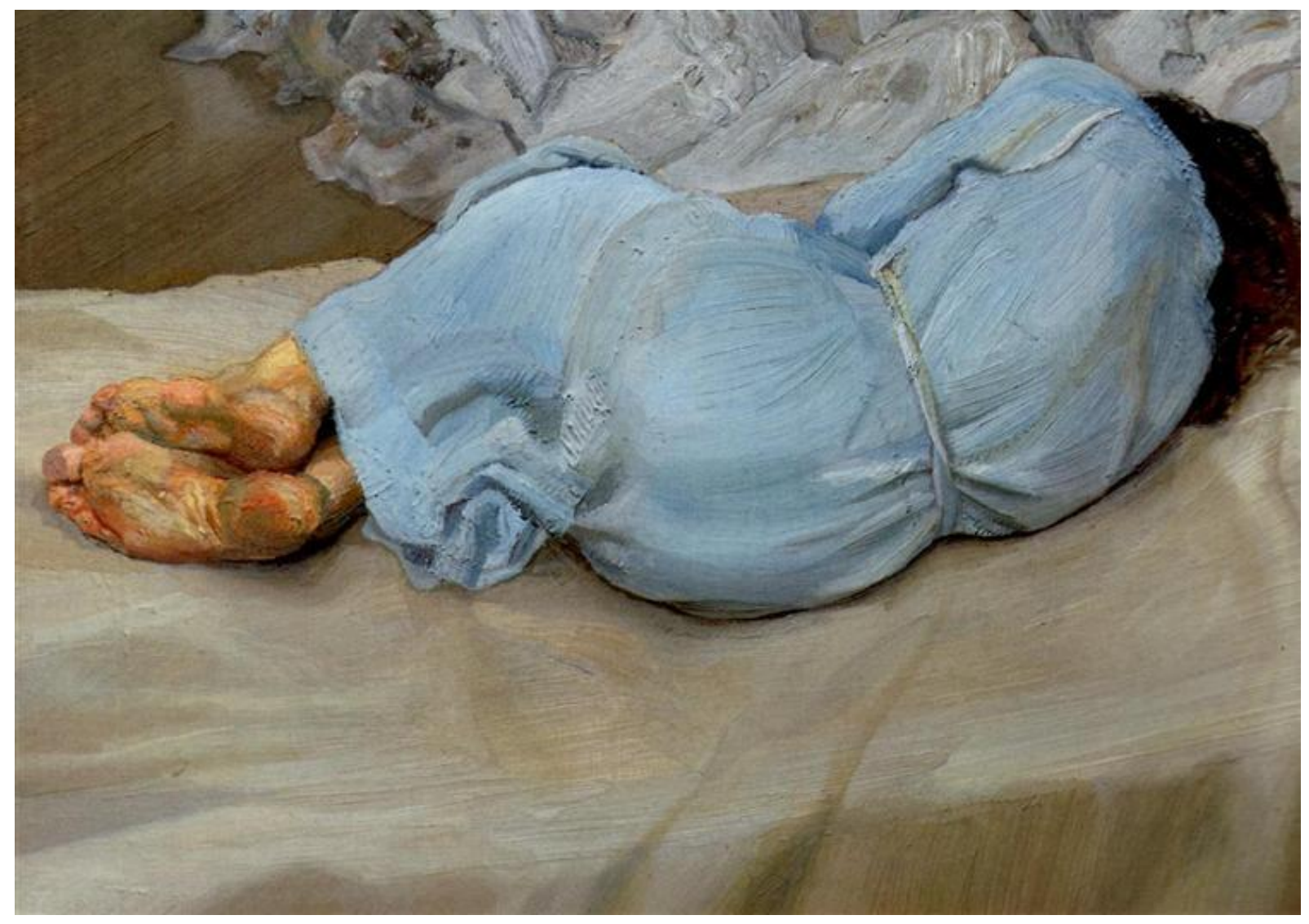

Annabel Sleeping (Lucian Freud, 1987-1988) 


\subsection{A iconografia das dietas: a imagem do corpo-imagem}

Em seu trabalho de pesquisa sobre imagens e dizeres do/sobre o corpo e divulgadas no ciberespaço sobre práticas corporais das festas rave, Azevedo (2013, p. 43) observou que as imagens que circulam na internet, em sua forma sobredeterminada pela mídia, passam a compor um universo de evidências de sentidos que naturalizam certas significações para os corpos dos sujeitos (no caso específico, dos participantes das festas rave), a partir das formações ideológicas. É nesse processo - esclarece - que sentidos como os de beleza se constituem, através de um jogo de filiações históricas que os determinam, mas que jamais se estabilizam completamente.

O caldeirão de sentidos das imagens dos corpos produzidas pela mídia atua como um operador de uma memória discursiva inscrita sócio-historicamente sobre beleza, dietas e corpo. Para dissecar a iconografia das dietas, retomamos os conceitos descritos no capítulo 2, iniciamos uma abordagem conceitual sobre imagem, fomentando a importância dessa materialidade significante para o funcionamento do texto midiático das dietas e boa forma.

As imagens de corpos-perfeitos de celebridades estampadas em revistas ou nas versões digitais dessas publicações suscitam dizeres de diferentes sujeitos-leitores. Sabemos que esses dizeres reproduzidos pelas revistas são enviesados, escolhidas pelos editores para ratificar o discurso predominante. Caso enviássemos uma mensagem criticando as armadilhas da linguagem publicitária e as modificações nas imagens, dificilmente esse texto seria publicado por alguma das revistas ou sites presentes em nosso corpus. No entanto, há sujeitos-leitores que se disponibilizam a enviar tais comentários para uma determinada publicação. Interessa-nos, aqui, o discurso daqueles que assumem a posição sujeito-leitor e as práticas sociais para reelaborar a relação que tem consigo próprio ao serem interpelados pela ideologia midiática das dietas. Mesmo advindo de diferentes enunciadores, o recorte abaixo "nos faz ver a insistência de uma versão" (Orlandi, 2012a, p. 67) ${ }^{128}$ :

\section{Recorte 20129:}

Difícil ter uma capa mais linda do que essa com a Angélica. Minha ídola é gataaa.

Comprei e adorei a Angélica na capa. Ela está com o corpo lindo. Parabéns, SHAPE!

\footnotetext{
128 Os leitores podem enviar suas mensagens às revistas por e-mail ou redes sociais. A conjugação dos suportes midiáticos (revista impressa e ambiente virtual) será discutida mais adiante.

${ }^{129}$ Comentários publicados na revista Shape (edição n. 67).
} 
Angélica é TUDOOO!

Angélica perfeita!

Angélica está cada dia mais linda!!!!!!

Parabéns pela capa estonteantemente liiiindaaaa. Adoramos TUDO! Está maravilhosaaa

[...] Não estou nem perto do meu peso ideal, mas aprendi muito com a revista e estou cada vez mais mudando meus hábitos e muito feliz! Tenho esperanças renovadas cada vez que compro a revista! Estou escrevendo para dividir essa felicidade com vocês, obrigada por fazerem parte da minha vida!

\section{Recorte $21^{130}$}

A capa com a Tatá Werneck é uma das minhas favoritas deste ano. Gostaria de parabenizar a Corpo a Corpo pela escolha e dizer que o ensaio ficou lindo. Destaque para o cabelo e figurinos deslumbrantes! Já estou ansiosa para saber quem será a próxima musa da Corpo. Arrasaram!

\section{Recorte 22 ${ }^{131}$ :}

Fiquei impressionada com as curvas da Letícia na capa da Corpo. Ela está maravilhosa na novela e foi a escolha perfeita para a revista. Arrasaram!

Adicionei à minha rotina de treinos para o bumbum, feita por Letícia, e os resultados têm sido ótimos! A combinação de exercícios é incrível e já consigo sentir a diferença na região. Tomara que com isso eu consiga ficar com um corpão como o dela.

Expressões como "minha ídola está com o corpo perfeito", "fiquei impressionada com as curvas da Letícia”, além dos comentários específicos sobre as imagens das capas revelam uma posição sujeito-leitor-consumidor não apenas das próprias revistas, mas dos ideais que elas apregoam. Essa relação é óbvia: está explícita na linguagem. A questão que podemos levantar a partir dos recortes 20 a 22 é: com qual corpo a posição sujeito-consumidor ou sujeito-leitor se identifica? Podemos afirmar categoricamente: o sujeito-leitor dos recortes acima identificase com formatos de corpos que não existem. Existir no sentido de ter existência concreta, material, como um corpo vivo. As imagens empregadas pelo discurso midiático das novas dietas são relatos homogêneos de um corpo-imagem, que faz parte de um projeto de corpo (corpo-projeto) $)^{132}$, geradas artificialmente por programas de computador e transformadas em imagens idealizadas de uma perfeição magnífica e incomparável.

\footnotetext{
${ }^{130}$ Comentários dos leitores publicados na revista Corpo a Corpo (edição n. 320). Falaremos mais sobre a relação do sujeito com as celebridades no capítulo 2 (2.6 - A consumidora consumida (corpo-projeto): "sei que eu vendo").

${ }^{131}$ Comentários dos leitores publicados na revista Corpo a Corpo (edição n. 315).

132 No início de nosso texto tecemos algumas considerações sobre o corpo-projeto. Tanto o corpo-imagem quanto o corpo-projeto, entre tantas outras formas-sujeito de corpos que se entrelaçam no discurso das dietas, foram e continuarão a ser objeto de nossa reflexão até o fim do nosso percurso investigativo.
} 
Nesse jogo, percebemos o funcionamento da ideologia legitimando o que deve ser compreendido como formato (imagem) do corpo contemporâneo. O corpo-imagem é produzido pelas publicações impressas ou virtuais sobre dietas e boa forma a partir de imagens de corpos do mundo real. Ao que tudo parece, modelos reais passam por uma série de transformações (reais e digitais) para ganharem contornos melhores, cujo resultado é sempre uma imagem perfeitamente bela, algo sublime construído tecnicamente. Essas imagens, atreladas aos enunciados sobre as novas dietas e boa forma, atuam como vitrines para a venda de toda uma gama de produtos ou procedimentos para emagrecer. O corpo-imagem não vende apenas produtos tangíveis, mas faz circular efeitos de sentidos sobre o corpo-projeto. Fixado à ideologia do corpo-projeto, o corpo-imagem faz também circular efeitos de sentidos dominantes sobre o formato que o corpo da mulher deve ter nos dias de hoje, efeitos de grandeza, sucesso, superioridade, dimensões que se projetam com especial força pragmática sobre o sujeitomulher.

Essa projeção faz parte da materialidade do próprio sujeito - a significação do corpo não pode ser pensada sem a materialidade do sujeito (Orlandi, 2012b). "Como unir corpo, sujeito, sentido, pensando a questão da materialidade discursiva?", questiona Orlandi (2012b, p. 13). O funcionamento discursivo das dietas e boa forma, tendo como uma das materialidades significantes o corpo-imagem, pode ser um caminho para responder a esse questionamento. $\mathrm{O}$ corpo-imagem presente nas Formações Discursivas e ideológicas das dietas, ao interpelar o sujeito, pode interferir na relação desse sujeito com o seu próprio corpo. Aqui podemos perceber o efeito da ideologia (das dietas e boa forma) que faz circular efeitos de sentidos em uma ambiência midiática onde estão inseridos os sujeitos e suas práticas sociais. Consequentemente, eles estão (re)significando, dando sentido à sua existência por intermédio de práticas discursivas: "enquanto corpo-simbólico, corpo de um sujeito, ele é produzido em um processo que é um processo de significação, onde trabalha a ideologia, cuja materialidade específica é o discurso" (Orlandi, 2012b, p.16).

E na ilusão de tentar a todo custo modelar o corpo físico em um corpo-imagem, metafísico, que não corresponde à realidade, o sujeito é exposto a uma séria de armadilhas provenientes de um discurso que se materializa em textos e imagens ilusórias. Discurso que interpela ideologicamente o sujeito a fazer todo esforço para alcançar o corpo idealizado em revistas e sites. Desta forma, o corpo do/no discurso midiático das dietas não pode ser pensado apenas como corpo empírico, mas o corpo em sua materialidade significativa. Não podemos, como reforça Orlandi, pensar o "sujeito sem a ideologia, e a ideologia sem a materialidade, a história e os processos da vida social e política" (2012b, p.16). São esses efeitos ideológicos de 
evidência que tentamos analisar no decorrer de cada capítulo e a cada sequência discursiva. $\mathrm{O}$ que pretendemos investigar no decorrer deste trabalho não se revela apenas na materialidade da linguagem ou da imagem, mas nos efeitos de sentido provenientes desse contexto discursivo/midiático.

Como veremos adiante, as imagens são tecnicamente modificadas para esconder as imperfeições do corpo da realidade, e o discurso midiático das novas dietas e do corpo perfeito procura não deixar margem a outros efeitos de sentidos que não os impostos pela ideologia do corpo-perfeito. Sabemos, no entanto, conforme aponta Orlandi (2005), que nem a linguagem, nem as imagens, nem os sentidos nem os sujeitos são transparentes: eles têm a sua materialidade e se constituem em processos em que a língua, a história e a ideologia concorrem conjuntamente. "Linguagem, sujeito e história não têm transparência porque têm materialidade. Em sua reação contraditória. E estão afeitos ao funcionamento da ideologia" (Orlandi, 2012b, p.16). Os sujeitos do/no discurso midiático das dietas estão afeitos à ideologia das dietas e boa forma, sendo interpelados por artifícios significantes como o corpo-imagem.

Discursivizando sobre a necessidade de fazer os esforços empreendidos por seus ídolos, o sujeito-leitor é interpelado pela formação imaginária de um corpo perfeito e completamente acessível, o que induz a práticas sociais para emagrecer:

\section{Recorte 23 ${ }^{133}$ :}

Sempre usei a falta de tempo como desculpa para não cuidar do meu corpo. Ler a entrevista com a Letícia me deu um novo ânimo para voltar a correr e conquistar as curvas que sempre quis. Pura inspiração! (grifos nossos)

Os recortes anteriores funcionam de modo a dar pistas do sujeito que, segundo Mariani (1998, p. 32), ao enunciar se projeta imaginariamente na forma-sujeito da Formação Discursiva que o domina, incorporando, desse modo, sua realidade, e os sentidos enquanto sistema de evidências e de significações percebidas, aceitas e experimentadas. Diariamente, recebemos uma avalanche de informações. No caso dos produtos e métodos para emagrecimento, há um “constante dilúvio de notícias sobre dietas" (Foxcroft, 2013, p. 11). Imagens e textos divulgados nos mais diversos suportes midiáticos podem ser acessados, por meio dos dispositivos tecnológicos de comunicação e informação, a qualquer hora, em qualquer lugar. Esse grande aparato midiático coevo de geração e distribuição de informação é o texto da mídia. Onipresente, seu poder alcança tanto a esfera pública quanto a privada. É preciso ressaltar, no

\footnotetext{
${ }^{133}$ Comentários dos leitores publicados na revista Corpo a Corpo (edição n. 315).
} 
texto da mídia, a força da interpelação do sujeito contemporâneo pelas imagens (Payer, 2005). "A introdução da imagem em grande escala tem assim estatuto semelhante ao da introdução da imprensa na difusão do livro" (Payer, 2005, p. 16). A imagem é discurso, diz Orlandi: "assim como qualquer materialidade significante, também a imagem não é transparente. É materialidade. Tem seu modo de funcionamento" (2012a, p. 63). A imagem é passível de interpretação.

Como já citado anteriormente, Pêcheux (2010, p. 51) assinala que a imagem seria um operador de memória social, comportando no interior dela mesma um programa de leitura, um percurso escrito discursivamente em outro lugar. Para Davallon (2010, p. 30), a imagem é um operador de simbolização, um dispositivo que pertence a uma estratégia de comunicação. $\mathrm{Na}$ estratégia publicitária das dietas, a imagem é um recurso fundamental. É ela quem traz à tona e dá vida ao corpo-projeto. Desta forma, pretendemos investigar e compreender o seu modo de funcionamento:

\begin{abstract}
A constituição do sentido se materializa em uma relação do sujeito com a língua e com a imagem em sociedade, já que cada sociedade constrói uma simbologia coletiva que nutre o imaginário social e faz parte do interdiscurso. [...] A recorrência com que a escrita é articulada à imagem, especialmente à imagem constituída por dados fotográficos e digitais manipulados eletronicamente, sinaliza para o que interpretamos como uma articulação construída, mobilizada pela força que o discurso pode ganhar ao se investir em diferentes materialidades (Medeiros, 2009, p. 92).
\end{abstract}

As imagens das revistas e sites de dietas e boa forma compõem uma iconografia das dietas, que age de forma articulada à linguagem, exercendo influência significativa sobre o sujeito. São imagens de corpos-perfeitos (sempre magros), mulheres praticando exercícios (sempre sorridentes), produtos diversos (para auxiliar o sujeito a alcançar o corpo-perfeito). A maioria dos corpos são de celebridades, como atrizes e famosas. Mas há também modelos ou atletas contratados para divulgar produtos e serviços.

As imagens dos corpos da iconografia das dietas parecem ser manipuladas digitalmente para obter requintes de magreza e perfeição, extinguindo-se qualquer defeito presente na verdadeira forma física. Nesses termos, o corpo é esticado, os cabelos e a pele ficam mais brilhantes, os dentes são sempre branquíssimos. Essa imagem reverbera sentidos de evidência de um corpo perfeito, delgado, liso, silenciando as imperfeições da realidade. A ideologia do corpo-projeto propagada pela mídia produz sentidos naturalizados como únicos possíveis, evidências que resultam em um processo de apagamento da materialidade do sujeito, já que "a evidência, produzida pela ideologia, representa a saturação dos sentidos e dos sujeitos 
produzida pelo apagamento de sua materialidade, ou seja, pela sua des-historicização", através de "processos em que perde-se a relação com o real, ficando-se só com (nas) imagens" (Orlandi, 2009, p. 55). Esse apagamento da materialidade do sujeito contemporâneo e a perda da relação com o real, essa complexa fusão corpo-imagem é algo extremamente perigoso: o sujeito não deve (e é constantemente assediado para isso) estar acima do peso considerado aceitável não do ponto de vista da medicina, mas de um critério estético propagada pela mídia. O sujeito é convocado a submeter-se "a qualquer sacrifício para apagar o tempo e suas marcas, escritas, sinais e cicatrizes" (Baitello, 2012, p. 91). A magreza, que já remeteu às doenças que enfeavam e matavam homens e mulheres (Del Priore, 2006), hoje é condição indelével da beleza.

Quando dissemos que a fusão corpo-imagem é perigosa, reportamos, por exemplo, aos casos relatados pela imprensa de jovens que morreram em decorrência de Anorexia Nervosa, transtorno de comportamento alimentar que se desenvolve principalmente em meninas adolescentes e mulheres jovens e caracteriza-se por uma grave restrição da ingestão alimentar, busca incessante pela magreza, distorção da imagem corporal e amenorréia. Ao fazer uma revisão sobre a Anorexia Nervosa, Weinberg e Cordás (2006) reiteram a necessidade de refletir sobre o que deriva diretamente do processo orgânico e o que configura a contribuição social e cultural dos sintomas na gênese desse transtorno.

Em relação às doenças graves como Anorexia Nervosa e Bulimia, entre outras, Baitello (2012) reforça que não é sem motivo que tanto preocupam pais e médicos as enfermidades ligadas à imagem corporal, em especial quando há uma busca por uma imagem corporal idealizada, como a propagada pela mídia e pelo universo virtual da boa forma. Na tentativa de diminuir ou deslocar os efeitos de sentidos provocados pelo fascínio das imagens tecnicamente manipuladas, o Projeto de Lei n. ${ }^{\circ}$ 6.853/2010 prevê a inclusão de uma mensagem de alerta em peças publicitárias ou publicadas em veículos de comunicação que apresentem imagens que tenham sido modificadas. O objetivo é alertar os consumidores/leitores sobre modificações em fotografias de peças publicitárias ou jornalísticas.

Apensado ao Projeto de Lei 6.853/2010 está o Projeto de Lei 704/2011, que estabelece a obrigatoriedade de aviso de saúde que especifica em fotos de modelos que forem manipuladas digitalmente. Diz o projeto ${ }^{134}$ :

Essas imagens podem fazer as pessoas acreditarem numa realidade que, com frequência, não existe. Portanto, é urgente uma advertência em todas as fotos manipuladas por qualquer meio e programa, como o Photoshop, as quais

\footnotetext{
134 Recuperado em 1 de dezembro de 2015, de http://www.camara.gov.br/proposicoesWeb/fichadetramitacao?idProposicao=494607
} 
devem conter a seguinte explicação: "fotografia retocada para modificar a aparência física de uma pessoa". A divulgação desses padrões irrealistas de beleza, muitas vezes exibidos no mundo da moda, podem causar vários tipos de problemas psicológicos, principalmente desordens alimentares em jovens que buscam um padrão inatingível de beleza. Não é à toa que abundam os programas de edição de fotografias: PhotoScape, Photoshop, The Gimp, PaintNet, PhotoFiltre, Photo Editor, Magix FunPix Maker, Shutterfly Studio, Taaz, Photo-Brush, Magix Etreme Photo Designer, FotoFlexer, Xnview, PicPick e tantos outros com nomes sugestivos. Há alguns anos depois do anúncio da morte de mais uma jovem em decorrência de distúrbios alimentares, a Câmara Técnica de Nutrologia do Conselho Regional de Medicina do Estado de São Paulo divulgou nota oficial na qual "apela para que as autoridades responsáveis pela Saúde Pública brasileira definam e apliquem normas rigorosas - a exemplo de outros países, como a Espanha, capazes de prevenir e coibir, nos diferentes setores envolvidos, atitudes e práticas que têm causado adoecimento e morte de crianças, adolescentes e jovens devido a restrições dietéticas (grifos nossos).

O autor do projeto esclarece que é necessário combater a veiculação de imagens deturpadas de modelos, sobretudo de mulheres na imprensa, em embalagens de produtos e comerciais, além de listar casos de adolescentes e jovens que morreram em razão de distúrbios alimentares. Os retoques feitos com photoshop deixam as modelos quase perfeitas, criando a idealização de um corpo impossível de se atingir, observa Deram (2014). Em alguns casos a modificação da foto original é tão bizarra a ponto da celebridade não se reconhecer na imagem adulterada. Após ter sua foto editada para uma capa de revista, uma celebridade desabafou nas redes sociais: "Gente, essa não sou eu"135.

Enquanto desenvolvíamos esta pesquisa, em $1^{\circ}$ de outubro de 2017 entrou em vigor na França uma lei que determina que fotos de modelos alteradas por programas de processamento de imagens deverão conter a mensagem "Photographie retouchée". Em reportagem publicada no site do canal de televisão francês BFM TV ${ }^{136}$, a ministra da Saúde na época, Marisol Touraine, argumentou que "Il faut agir sur l'image du corps dans la société pour éviter la promotion d'idéaux de beauté inaccessibles et prévenir l'anorexie chez les jeunes" "137. A lei se aplica no contexto comercial ou publicitário e tem como objetivo "empêcher le développement de l'anorexie et de la boulimie chez les jeunes, par mimétisme de leurs icônes de mode"138. Iniciativas próximas à francesa já ocorreram em Israel, onde é obrigatório sinalizar alterações

\footnotetext{
135 Recuperado em 29 de junho de 2016, de http://tvefamosos.uol.com.br/noticias/redacao/2015/12/30/anahickmann-aparece-irreconhecivel-em-revista-e-reclama-nao-sou-eu.htm

136 Recuperado em 8 de janeiro de 2017, de http://www.bfmtv.com/societe/la-mention-photo-retoucheedesormais-obligatoire-sur-les-photos-de-mode-1266667.html

137 “Devemos agir sobre a imagem do corpo na sociedade para evitar a promoção de ideais de beleza inacessíveis e prevenir a anorexia entre os jovens". Livre tradução do autor.

138 "Prevenir o desenvolvimento de anorexia e bulimia em jovens, por mimetismo de seus ícones de moda". Livre tradução do autor.
} 
digitais em fotos de moda desde 2013. Essa prática também existe na Austrália desde 2010, de forma voluntária.

Com poses estudadas, basta folhear revistas de boa forma para perceber que as imagens técnicas são aperfeiçoadas para se tornarem melhores que os corpos tradicionais. Os corposimagens produzidos pela mídia e seus aparatos tecnológicos (como os programas de edição de imagens) apresentam várias características: não possuem manchas (quando aparecem, são quase imperceptíveis); são magros; os cabelos são esvoaçantes e brilhantes; são lisos - não possuem dobras ou sinais visíveis de gordura nem quando seus membros (braços, pernas ou barriga) estão curvados.

As formações ideológicas e discursivas do texto midiático das dietas e boa forma acabam por determinar o visual que as mulheres devem conquistar. É um caso de saúde pública, assegura Deram (2014, p. 54): “algo que afeta a todos nós e está nos matando devagar. Hoje, o Brasil e os demais países do mundo foram acometidos por epidemias de transtornos alimentares". Negar ao sujeito à possibilidade de ser o que não se pode ser, de alcançar o inalcançável, o discurso das dietas e da magreza interpela os sujeitos de modo a criar um paradoxo que chamaremos de "negação exposta". As imagens do corpo-perfeito são constituídas de uma obscuridade cintilante: à luz do seu brilho e perfeição está oculto seu lado sombrio, sua incompatibilidade com a realidade. Podemos ir mais longe e dizer que nossas fobias também estão ali dissimuladas (nosso medo do desagradável, do feio, do envelhecer, do diferente, do imperfeito).

Os suportes midiáticos fazem circular imagens de corpos supramundanos, que não condizem com a realidade dos indivíduos que habitam este planeta, interpelando o sujeito a ser como elas são, a admirar o que parece ser uma verdade, mas não passa de um efeito de um constructo técnico de edição de imagens. O verbo alterar (no sentido de modificar uma imagem) também traz consigo efeitos de perturbar, desequilibrar. A imagem do corpo modificada tecnicamente perturba o sujeito-mulher. Esse é o fundamento essencial das imagens midiáticas contemporâneas. A imagem está lá, convocando o sujeito a devorá-la e pronto para devorá-lo mas se nós não somos como a imagem dos corpos perfeitos e magros da mídia, a culpa é nossa. Não fazemos a quantidade de exercício físico necessário para tornear nossos músculos, não nos alimentamos adequadamente, não aderimos à dieta da moda, não compramos o último creme com substâncias que se propõem rejuvenescedoras. E, mesmo submetendo nosso corpo deliberadamente a tais investimentos, uma espécie de aplicação social na formatação corporal, ainda assim seria praticamente impossível editar nossa imagem corporal a ponto de atingir os patamares de excelência do corpo-imagem. Como já pontuamos anteriormente, jamais 
alcançaremos o corpo-perfeito das imagens midiáticas simplesmente porque elas não existem. Não passa de um corpo-metafísico, uma imagem bidimensional.

Contudo, reiteramos que a imagem, quando o toca o real, arde. Produz efeitos. Interpela o sujeito. De forma conjunta, os enunciados e as imagens midiáticas das dietas e boa forma constituem uma poderosa ferramenta da Formação Discursiva dominante do corpo-projeto. Continuando a nos debruçar sobre os nomes próprios das dietas, separamos mais alguns para exemplificar o funcionamento da icnografia das dietas, imagens que têm sua operacionalidade fixada aos enunciados (e vice-versa). Algumas dietas atribuem, através do discurso que as propagam, sentidos de poderes mágicos a algo real ou abstrato. Alguns exemplos são a Dieta do GH, a Dieta do Cortisol e a Dieta Mind.

A Dieta do GH é assim descrita:

\begin{abstract}
Recorte 24:
DIETA DO GH. Quer deixar seu corpo assim: magro e bem definido? Um dos segredos é estimular o hormônio do crescimento mesmo depois de grandinha. Aposte em um cardápio moderado em carboidratos e generoso em proteínas magras e gorduras boas que os resultados aparecem! ${ }^{139}$
\end{abstract}

A pergunta do enunciado acima: Quer deixar seu corpo assim? refere-se a uma imagem disposta ao lado do enunciado. Ocupando uma página inteira, a imagem é de uma modelo extremamente magra, vestindo um short curto e uma camiseta branca que, de tão curta, permite visualizar a barriga sarada e ausente de gordura. Ela faz uma pose sensual, com os braços definidos erguidos na altura dos ombros. Na mão direita, segura um abacate cortado ao meio e que está tampando seu olho direito. Os ombros estão para trás, as cortas arqueadas, as pernas afastadas e, apesar de pouco aparecerem na imagem, uma está à frente da outra. A postura adotada pela modelo faz o corpo parecer mais magro do que ele realmente é. O corpo-imagem que ilustra a matéria sobre a Dieta do GH é um projeto de corpo que interpela a mulher a (re)significar o seu próprio corpo em um processo de emagrecimento. E a estratégia para emagrecer está nas linhas que enaltecem os benefícios da Dieta do GH. Materialidades atuando conjuntamente e produzindo efeitos de "um ideal almejado", sentidos que atingem a mulher e a sua percepção corporal, o seu "estar no mundo" através do seu corpo. Aqui começamos a esboçar uma reflexão sobre o "outro do corpo", que abordaremos mais adiante, pois "se o sujeito se espelha na mídia visualizando outras imagens em si, que passa a perseguir como

\footnotetext{
${ }^{139}$ Matéria da revista Boa Forma (edição n. 343, p. 68).
} 
ideais, este reflexo não deixa de atingir o funcionamento simbólico mais geral no sujeito" (Payer, 2005, p. 21).

Se as imagens falassem, poderíamos questionar a modelo que ilustra a matéria: você faz a Dieta do GH? Qual o seu índice corporal? Seu índice corporal está adequado ou abaixo do que é considerável saudável? Quais os reais sacrifícios a que você se submete diariamente para manter esse corpo magro? A foto que você fez foi submetida a alterações digitais? Caso você engorde, mesmo que a balança aponte alguns poucos quilos a mais, ainda assim conseguirá participar desse tipo de reportagem? A manutenção de um corpo esguio é requisito para que você possa exercer sua profissão? A agência para a qual você trabalha estabelece medidas corporais que devem ser seguidas pelas modelos? Essas seriam algumas perguntas que poderíamos fazer ao corpo-imagem. Mas ele não fala, e ainda assim, produz sentidos. O corpoimagem ressignifica os sentidos sobre o corpo da realidade, embutindo novos efeitos de excelência e exatidão.

A reportagem referente ao recorte anterior sugere que a leitora deve seguir o cardápio elaborado por uma nutricionista. "O que você ganha com isso? Ops, perde! Pelos menos 4 quilos em 30 dias". Novamente, os números fazem vigorar efeitos de velocidade e imediatismo na perda de peso com a adoção de uma dieta específica.

\subsection{Corpo-projeto como o grande outro do sujeito: a geometrização do corpo e a homogeneização da pele}

As formas-sujeitos apresentadas até aqui vão ao encontro da tese defendida por Orlandi (2012a), ao ressaltar que a forma sujeito histórica tem sua materialidade e que o indivíduo, interpelado em sujeito pela ideologia, traz seu corpo por ela também interpelado. E um dos meios mais eficazes de interpelação do sujeito-mulher na atualidade é a imagem. Tanto a musa fitness brasileira Bella Falconi quanto a personal australiana Kayla Itsines adotaram o recurso da imagem para divulgar seus treinos focados na busca por um corpo-perfeito e uma barriga seca e desenhada. 

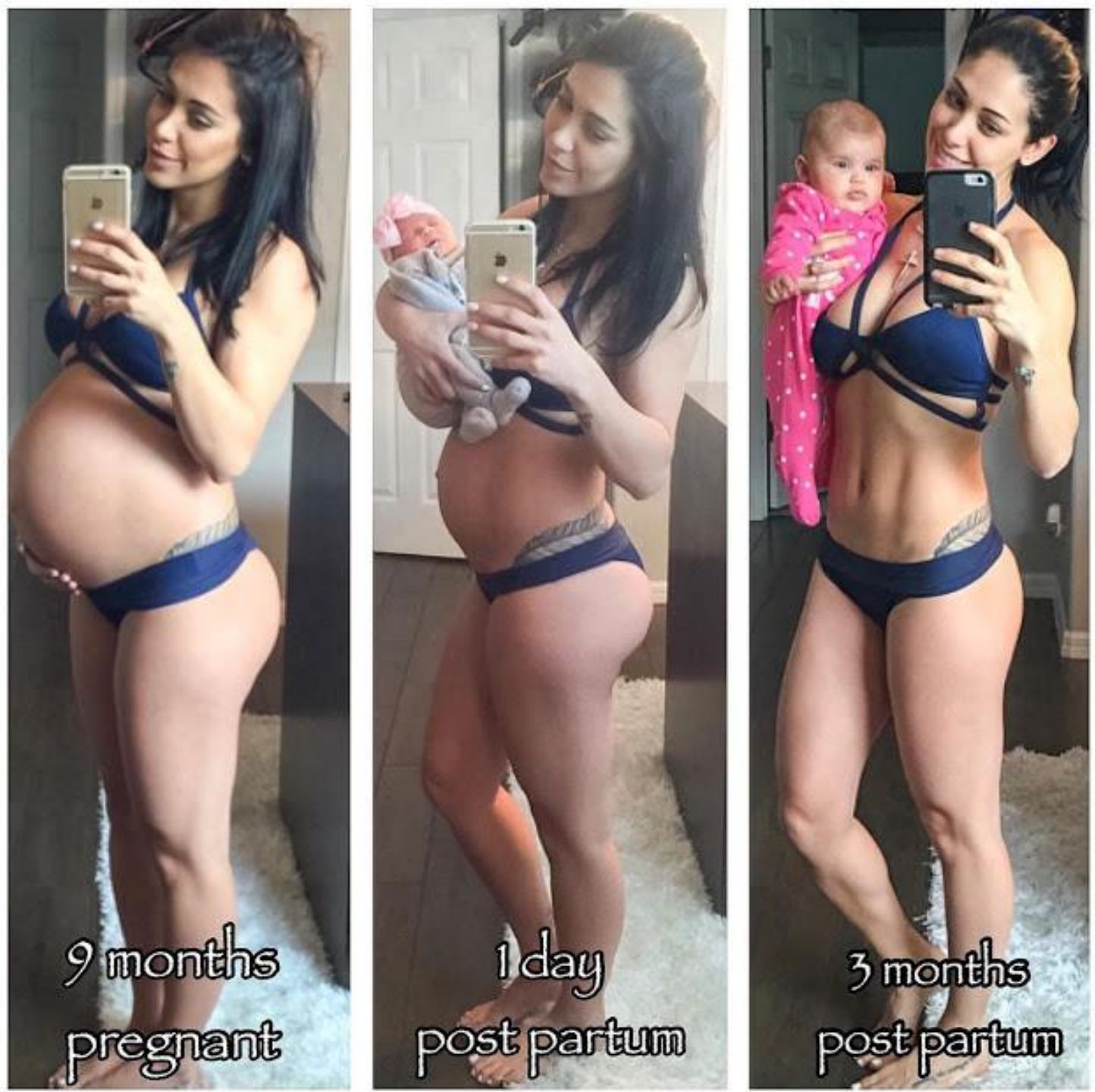

Figura 17. A musa fitness Bella Falconi expõe o formato do corpo durante e após a gravidez ${ }^{140}$

Teoricamente, ou melhor, discursivamente, a barriga dos sonhos está à disposição de toda mulher disposta a encarar a maratona de exercícios, dietas e outros artifícios para diminuir a circunferência abdominal. Pode ser através do "cardápio termofuncional", da "dieta das castanhas" ou do treino que a personal trainer australiana Kayla Itsines criou para "secar" a barriga, o Bikini Body Guide. Além dos exercícios, esse programa apresenta algumas particularidades características da ambiência midiática que estamos propondo desde o início deste trabalho. O primeiro aspecto é que Kayla Itsines é, assim como Gabriela Pugliesi e Bella Falconi, uma "top blogger", com 3,5 milhões de seguidores em seu perfil no aplicativo

\footnotetext{
${ }^{140}$ Recuperado em 5 de novembro de 2017, http://www.health.incommunseries.com/2015/11/bella-falconimostra-fotos-da-gravidez.html
} 
Instagram. O segundo aspecto é que ela publica diariamente, assim como as bloggers brasileiras, fotos da transformação do corpo das mulheres que praticam o treino criado por ela. Na reportagem "\#Barriga ostentação", a personal explica: “diferentemente de programas para perder gordura, ou ganhar músculos, meu tipo de treino é focado em alcançar um corpo que faça você parecer e se sentir confiante com a sua imagem" (grifos nossos) ${ }^{141}$. A estratégia de Kayla em divulgar imagens das mulheres que executam o seu programa vai ao encontro do que temos defendido até agora: Acesso, logo emagreço. Emagreço, logo existo!

Recordemos o que dissemos sobre a imagem no início de nosso percurso: a imagem é discurso e, quando aponta o real, arde. Resgatemos Didi-Huberman (2012): a imagem é uma impressão, um traço visual do tempo que quis tocar. Ela possui uma eficácia simbólica. No caso das dietas, ela funciona em um jogo discursivo que dá à imagem uma eficácia argumentativa: para se sentir confiante, a mulher deve ter uma barriga sarada; caso contrário, não pode exibir ou ostentar um abdômen que não seja totalmente isento de gordura. Ou corre o risco, como aconteceu com a Fluvia Lacerda na revista Playboy, ser taxada de "gorda". A foto de Marilyn Monroe sentada em uma praia exibindo dobrinhas na barriga não apresenta semelhança com nenhuma imagem veiculada nas publicações que investigamos para este trabalho. Mulheres acima do peso aparecem apenas em reportagens do tipo "antes e depois", que relatam como a perseverança de algumas leitoras permitiram que redesenhassem a silhueta em algum momento de suas vidas.

A iconografia das barrigas saradas também se legitima pela saturação que se dá pela repetição: as imagens são praticamente idênticas, de mulheres com a barriga perfeita, lisa, sem dobras, em sua maioria com os músculos do abdômen salientes, a tão desejada "barriga tanquinho". As sociedades atuais, diagnostica Kamper (2016), têm uma compulsão à repetição que, segundo ele, "ocorre no corpo, individual ou massivamente", "em círculos fechados, como uma corrida sem sair do lugar" (p. 85).

O pintor e cineasta americano Andy Warhol, ao fazer uso de repetições serigráficas em suas obras, parecia denunciar ou até mesmo zombar da "serial imagery society" (Baitello, 2005, p. 51), uma situação comum em nossa época de reprodução e circulação de imagens, algo que também havia sido vislumbrado por Walter Benjamin em seu ensaio "A obra de arte na era de sua reprodutibilidade técnica".

${ }^{141}$ Matéria da revista Boa Forma (edição n. 347, p. 36). 


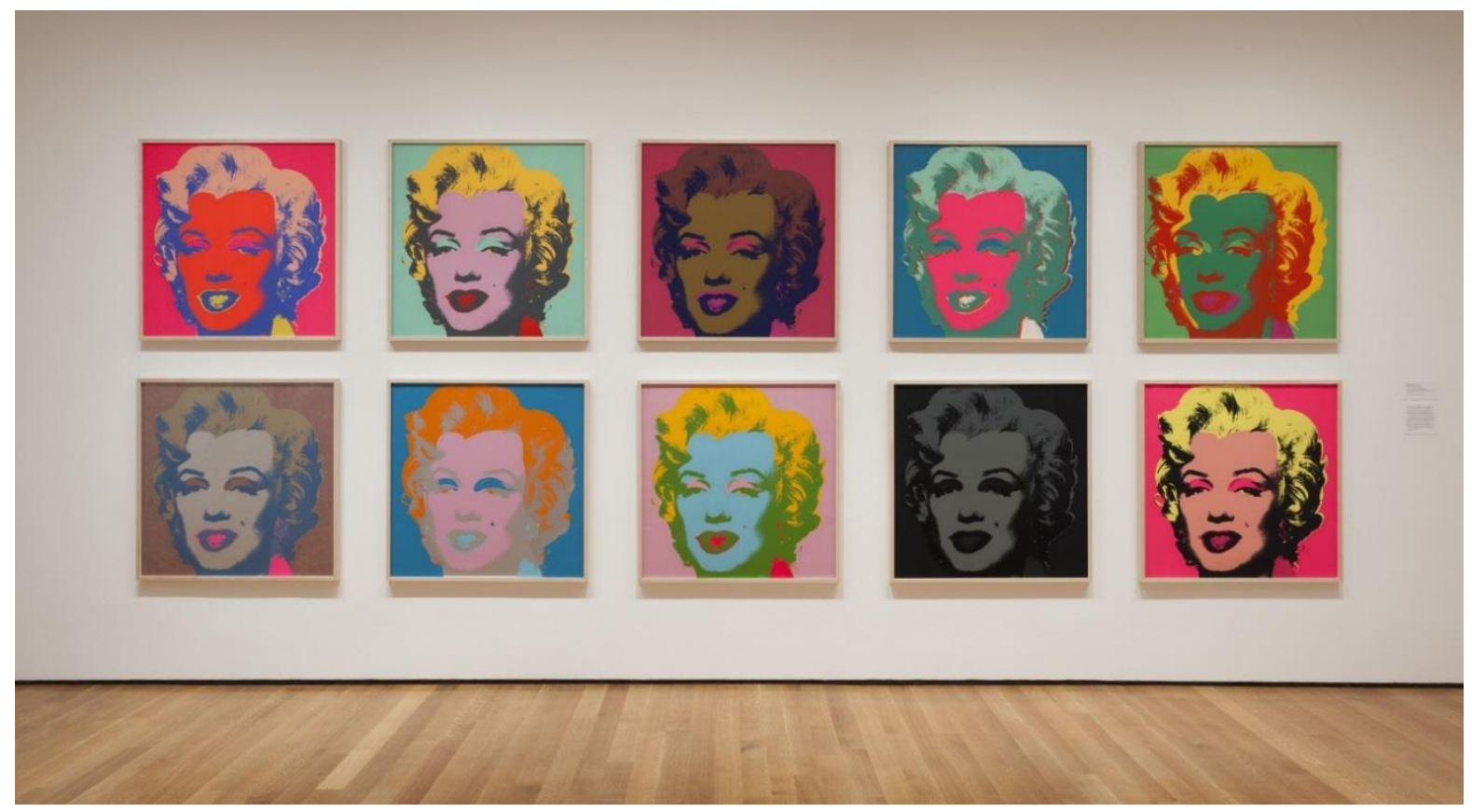

Figura 18. Andy Warhol: Campbell's Soup Cans and Other Works, 1953-1967

The Museum of Modern Art Archives, Nova Iorque (Estados Unidos) ${ }^{142}$

A essa altura do nosso percurso investigativo, com as considerações que fizemos até o momento, e compreendendo a imagem como um discurso, chegamos a um ponto crucial no vínculo entre corpo e imagem: a imagem (corpo-imagem) é uma construção ideológica do corpo, portanto, inferimos que ela atua como um grande outro do corpo. Na economia de mercado, a mídia, estimulada pelos dispositivos tecnológicos/comunicativos, é como uma arma que dispara imagens em um ritmo alucinante. Imagem para o consumo e para expandir o consumo (Bucci, 2004, p. 184). Um dos principais estudiosos da imagem sustenta que hoje podemos afirmar que o outro do corpo é a imagem:

Esse é um ponto central a ser compreendido na relação do corpo com a imagem. De alguma maneira, aqui se colocam corpo e imagem em uma relação de oposição. Quer dizer, corpo se coloca contra a imagem e a imagem se coloca contra o corpo. Ao mesmo tempo, um se espelha no outro, desejando-o. Este é um grande tema contemporâneo: a imagem é o outro do corpo. [...] Quando o corpo quer se tornar uma imagem ideal, podem surgir doenças graves como a anorexia, a bulimia e tantas outras. Ou ainda, em grau menos avançado, a escravidão dos corpos ideias e das medidas-padrão demonstra que vivemos uma era em que a imagem tente impor ao corpo seus parâmetros de imagem (Baitello, 2012, p. 91).

\footnotetext{
142 Recuperado em 5 de novembro

https://www.moma.org/calendar/exhibitions/1517/installation_images/29?locale=em
}

de 
Assim como somos influenciados desde que nascemos ao estabelecermos elos sociais e afetivos com outras pessoas, portanto, com outros corpos, a nossa sociedade deu um passo além: não apenas o outro, um organismo pulsante, exerce influência sobre nossa subjetividade. Do mesmo modo, a imagem tecnicamente produzida e que circula na mídia exerce influência preponderante sobre quem somos, como vivemos, como vemos, sentimos e nos relacionamos com nosso próprio corpo. O antropólogo francês Stéphane Malysse, ao tratar das representações sociais e dos usos do corpo na sociedade brasileira em uma pesquisa de campo realizada no Rio de Janeiro, percebeu que "a visão do corpo do outro influenciava a percepção que cada indivíduo tinha de seu próprio corpo, e que, por meio de um processo de mimese social, o visual tornava-se corporal" (Malysse, 2002, p. 86).

Nesta tese defendemos que, na Formação Discursiva das dietas e do corpo-projeto, ocorre um fenômeno que denominaremos "mimese imagética", composta por redes de relações significantes entre imagem (corpo-imagem) e corpo (real) e que exerce influência direta na configuração corporal da mulher na atualidade. A mimese imagética atua em uma guerra de imagens que, segundo Kamper (2016), ainda não alcançou o seu auge:

O olhar controlador, que já é global, força implacavelmente os homens a se transformarem em uma imagem que não escape à moldura imposta e satisfaça aos requisitos da visibilidade ampliada. Tudo o que não é visível é tido como inútil e descartado antes mesmo de entrar no jogo. Por sua vez, a imagem apropriada ao olhar, com a participação daquele que é olhado, pode ser formada ativamente nas repetidas encenações de toda uma vida (p. 71).

De alguma maneira, explica Baitello (2012), imagem e corpo não podem ser pensados apenas em uma relação de oposição, mas de espelhamento: um se espelha no outro, desejandoo. Portanto, o outro do corpo é a imagem. E isso se revela no discurso midiático das dietas, quando o outro do corpo é uma imagem impecável e repetida à exaustão. A imagem, diz Pêcheux (2010, p. 51), comporta em seu interior um programa de leitura, um percurso inscrito discursivamente, e o "efeito de repetição e de reconhecimento faz da imagem como que a recitação de um mito". Enquanto organismo, as imagens não possuem sensorialidades, são desprovidas de qualquer sentimento. Enquanto discurso, elas emanam sentidos carregados de significados que despertam emoções, sensações, afetos, conflitos, impressões. O corpo-imagem não envelhece, não sente dor, angústia, medo ou solidão. Mas têm o poder de provocar esses sentimentos nos corpos reais a medida que "a interioridade do sujeito é um constante esforço de exterioridade, reduz-se à sua superfície" (Le Breton, 2003, p. 29). Em nossa época, a forma sujeito-mulher é constantemente bombardeada e estimulada a se ajustar às medidas impostas 
pelo corpo-imagem das dietas, em um esforço incessante de abreviar a mulher à sua exterioridade, a resumir suas complexidades e vivências ao mero formato do corpo. Esse assédio midiático ocorre de forma peremptória:

\author{
Recorte 25 ${ }^{143}$ : \\ ESPECIAL TANQUINHO. Quer a barriga dela? Nós contamos como! \\ Alimentos antipochete + cardápio que detona $3 \mathrm{~kg}$ de GOR-DU-RA \\ Tratamentos exterminadores de dobrinhas. Pacotes high tech a partir de \\ $\mathrm{R} \$ 800$ \\ Exercícios que trincam mesmo do Mahamudra, do balé, do pilates
}

A insegurança é um dos principais pilares que fundamentam boa parte dos comentários (portanto, dos textos que circulam na mídia), sobre dietas e forma física (Foxcroft, 2013). Dentre tantos outros, o discurso da barriga-perfeita faz circular efeitos de sentidos que evocam medo e insegurança (dobrinhas, pochete, gordura abdominal, flacidez são adjetivos que devem ser combatidos, detonados, mesmo após um fenômeno natural como a gravidez); modelamento do corpo (a pele e os músculos devem ficar trincados, duros, esticados); superação (é preciso conquistar os resultados e estes devem estar visíveis, como o um abdômen sarado); hegemonia, supremacia (somente as barrigas saradas são aceitas socialmente e podem ser mostradas, exibidas, além de ostentarem alta conotação sexual). Estés (2014, p. 234) pondera que "não é de espantar que na nossa cultura coexistam a questão de esculpir o corpo natural da mulher, a questão correlata de entalhar a paisagem e ainda a de retalhar a cultura em partes que estejam na moda".

Não há nada que a leitora não possa fazer, como reforça um dos enunciados sobre roupas femininas que deixam a barriga à mostra. "Peças com abertura na cintura estão em todas as vitrines, mas exigem uma barriga sem pneuzinhos. Por mais que pareça difícil, no mundo da moda - assim como no fitness -, nada é impossível!"144, enfatiza um texto com dicas de exercícios para afinar a cintura. Nada, reforça o enunciado, é impossível - ou seja, tudo é possível para quem quer, faz, almeja, sonha, deseja, consome. A avidez com que o sujeitoleitor-mulher busca esse padrão de corpo estruturado pela mídia é um fenômeno retroalimentado pela repetição desse mesmo discurso.

A repetição de imagens de abdomens delineados, em conjunto com os textos (que aqui defendemos como construções linguísticas de cunho publicitário), compõem um discurso

\footnotetext{
${ }^{143}$ Chamadas de capa da revista Corpo a Corpo (edição n. 320).

${ }^{144}$ Matéria da revista Boa Forma (edição n. 343, p. 102).
} 
poderoso da Formação Discursiva das dietas e do corpo-projeto. Uma das estratégias adotada pela mídia das dietas e boa forma é a geometrização do corpo. O corpo, que deveria ser visto como um todo, é compartimentado, retalhado, para ser trabalhado parte a parte, pedaço por pedaço, ou para usar uma linguagem empregada pela mídia do corpo-perfeito, músculo por músculo. Cada pedaço do corpo feminino é delineado de acordo com o padrão corporal vigente para ser mais feminino, sexualmente atraente e sempre jovial. O glúteo é uma das partes do corpo feminino que o discurso das dietas e boa forma ataca incessantemente. Ele não pode estar "fora de forma", ou seja, caído, com estrias ou celulite; assim como o corpo, ele só pode aparecer despido na mídia se apresentar as qualidades inerentes ao corpo-projeto. Como diz o enunciado do próximo recorte, o bumbum da mulher na atualidade deve exibir certas qualidades:

\section{Recorte 26:}

Bumbum dos sonhos. Redondo, durinho, empinado. Sim, esse é o sonho de consumo de 10 entre 10 mulheres quando o assunto são os glúteos ${ }^{145}$ (grifos nossos)

De acordo com essa reportagem, a moda dos biquínis asa-delta e fio dental, nos anos 1980, já previam “a nossa obsessão" por essa parte do corpo. O texto foca como a mulher pode eliminar ou resolver os problemas, em sua maioria estéticos, que atacam o glúteo, como flacidez, estrias, cravos, espinhas e a tão temida celulite. A obsessão citada na reportagem por essa parte do corpo pode, entre outras razões, advir de uma questão de ordem sexual. Em um estudo antropológico realizado no Rio de Janeiro acerca das representações sobre o masculino e o feminino nas camadas médias urbanas, uma das questões dirigidas aos homens era: $\mathrm{O}$ que mais o atrai sexualmente em uma mulher? As respostas foram: a bunda, o corpo e os seios (Goldenberg e Ramos, 2002).

Ao lado do enunciado acima, uma imagem ocupando a página inteira de uma mulher magra, de costas, usando biquíni, mostra um glúteo perfeitamente liso e magro. Não é possível visualizar seus ombros, pois a imagem está recortada, começando pouco acima do glúteo e estendendo-se até a altura dos joelhos. As pernas da modelo também são lisas e magras. O biquíni, vermelho, com dois laços nas laterais, parece se (com)fundir com a textura da pele. A imagem do bumbum perfeito vestindo um minúsculo biquíni vermelho, aplicada em outro contexto, como a capa de uma revista erótica, talvez sofresse algum tipo de classificação

\footnotetext{
145 Matéria da revista Corpo a Corpo (edição n. 324, p.87).
} 
indicativa relativa à nudez. Anexa em uma reportagem sobre boa forma, está autorizada a circular em publicações que estão ao alcance de todos, independentemente da faixa etária. $\mathrm{O}$ jogo de luz e sombra ressalta a perfeição da epiderme, sem nenhum sinal de mancha, cicatriz, estrias, celulite ou qualquer outro pequeno defeito. Não há, na espécie humana, nada parecido ou próximo desse tipo de lisura.

Como estamos observando desde o início desta tese, o discurso midiático das dietas e boa forma é repetitivo. As preocupações com o formato do glúteo, como também ocorre com outras partes do corpo feminino, são exaustivamente marteladas na mídia. Se o discurso é sempre o mesmo, os efeitos de sentidos também o são. E os efeitos apontam sempre para uma perfeição absoluta. Além da publicação referente ao enunciado acima, outra publicação que circulou praticamente na mesma época (uma de novembro e a outra, de dezembro de 2015) traz um texto sobre o que fazer para conseguir "derrière lisinho":

\footnotetext{
Recorte 27:

Em busca do bumbum perfeito. O treino da academia fez efeitos, mas você ainda fica incomodada com a celulite aqui e ali, uma estria que insiste em permanecer por lá ou a gordurinha que decidiu montar acampamento ${ }^{146}$ (grifos nossos)
}

A imagem que ilustra a reportagem do recorte acima é praticamente idêntica à que ilustra o texto do recorte 26. O biquíni, azul claro, as pernas levemente afastadas uma da outra. Não é necessário escrutinar a imagem para notar alterações digitais ainda mais abusivas, gerando um tom de pele sem nenhuma analogia com um corpo vivo. A imagem remete a um outro ser, que parece não ser deste planeta, um corpo mais evoluído e revestido por um material que em nada se parece com a epiderme humana.

A principal função da pele é defender o organismo dos efeitos e estímulos do meio ambiente. Fronteira do organismo, seu aspecto proporciona importantes informações, um reflexo do estado de saúde físico e mental de uma pessoa (Ullmann, Reis, \& Steibel, 2004). Se a pele tem a capacidade de denunciar o estado de saúde de um sujeito, a imagem dos corpos do discurso midiático das dietas suplantou o registro da existência daqueles corpos. Essa é a visão da medicina. A definição mais elegante e impactante que encontramos para pela é a do alemão Dietmar Kamper (2016, p. 88): “a pele é uma história em camadas de dores passadas. E, de modo algum, um receptáculo para carne e ossos". A homogeneização da textura da pele, sempre lisa e brilhante, não abre espaço para as emoções, a dor, o medo, a excitação. A epiderme dos

\footnotetext{
${ }^{146}$ Matéria da revista Women's Health (edição n. 85, p. 78).
} 
corpos midiáticos é manufaturada para promover efeitos de uma condição existencial asséptica. São sentidos de potência marcados na textura lisa e homogênea de uma pseudoepiderme. Poeticamente, Estés nos lembra que o corpo traz impresso na pele e nos ossos a sua história:

O corpo usa sua pele, sua fáscia e sua carne mais profunda para registrar tudo que ocorre com ele. Como a pedra de Rosetta, para aqueles que sabem decifrálo, o corpo é um registro vivo de vida transmitida, de vida levada, de esperança de vida e de cura. Seu valor está na sua capacidade expressiva para registrar reações imediatas, para ter sentimentos profundos, para pressentir. O corpo é um ser multilíngue. Ele fala através da cor e da temperatura, do rubor do reconhecimento, do brilho do amor, das cinzas da dor, do calor da excitação, da frieza da falta de convicção. Ele fala através do seu bailado ínfimo e constante, às vezes oscilante, às vezes agitado, às vezes trêmulo. Ele fala com o salto do coração, a queda do ânimo, o vazio no centro e com a esperança que cresce. O corpo se lembra, os ossos se lembram, as articulações se lembram. Até mesmo o dedo mínimo se lembra. A memória se aloja em imagens e sensações nas próprias células. Como uma esponja cheia de água, em qualquer lugar que a carne seja pressionada, torcida ou mesmo tocada com leveza, pode jorrar dali uma recordação (Estés, 2014, pp. 149-150).

A textura da epiderme dos corpos presentes no discurso midiático da boa forma não encontra semelhança no mundo real. São de outra espécie, sobre-humano, fabricados por programas de computador. Nascem dos corpos reais, mas encontram a perfeição nas máquinas de alteração digital. E são cultuados nas telas das máquinas de olhar. A imagem final, criada artificialmente, é o outro do corpo que circula produzindo pujantes efeitos de sentidos: são modelos esquadrinhados e impostos para cada pedaço do corpo da mulher. Modelos que suprimem as marcas do tempo, da vida, das vicissitudes da realidade.

$\mathrm{O}$ enunciado acima retoma um aspecto crucial do discurso das dietas e boa forma: o sujeito está inserido em um contex to econômico-capitalista. O corpo é vendido como um sonho de consumo, um produto a ser redefinido e remodelado, cujo dono é o próprio sujeito. Mas no processo de construção corporal, a mulher da atualidade, dona do próprio corpo, é interpelada a modificar as partes do corpo para poder exibi-lo. Estar no mundo com um corpo exige um formato pré-determinado, único exemplar autorizado a ser exibido. Se pensarmos em termos econômicos, o corpo é uma propriedade privada cujo uso e circulação ocorre em ambiente público, seguindo normas impostas por aspectos culturais e, em nossa época, discursos midiáticos.

Atuando em conjunto com as imagens, os enunciados compõem uma materialidade significante de uma Formação Discursiva que recorta o corpo em fragmentos a serem esculpidos, em um processo de "geometria corporal". Como já dissemos anteriormente, 
nenhuma gordura pode estar aparente. Seja nos braços, pernas, abdômen, glúteos, ombros: os músculos de cada parte do corpo devem estar sempre bem definidos e enxutos. Daí a necessidade constante da mídia em divulgar novas dietas para emagrecer muito e velozmente. Como podemos ver no próximo recorte, no caso das mulheres, algumas partes do corpo são bombardeados discursivamente para estarem constantemente definidas: o bumbum deve ser durinho; braços e pernas, torneados; os seios, empinados, em uma repetição exaustiva:

\author{
Recorte 28: \\ Foco no bumbum. Exercícios e produtos que empinam, moldam e endurecem. \\ Vai que dá ${ }^{147}$ \\ Bumbum ond demand [...] aplicativo gratuito que ensina exercícios para \\ glúteos e pernas que não requerem nenhum equipamento ${ }^{148}$ \\ BUMBUM SENSAÇÃO. 12 exercícios funcionais que modelam e \\ empinam ${ }^{149}$ \\ Marina Ruy Barbosa. Pernas e bumbum desenhados com 5 movimentos ${ }^{150}$ \\ TOP 5 MOVIMENTOS: abdome, bumbum, pernas e braços ${ }^{151}$ \\ Pernas e bumbum dos sonhos com 8 movimentos. A Paloma Bernardi faz! ${ }^{152}$
}

A repetição discursiva promove um esgotamento dos sentidos, apontando para uma única direção, um único formato. A palavra de ordem é "foco", além de outros sentidos que permeiam o discurso das dietas e ecoaram em diferentes recortes até aqui analisados: facilidade (modele uma determinada parte do seu corpo com apenas 5 ou 8 movimentos); idealização, ânsia e, acima de tudo, desejo por um corpo definido (bumbum dos sonhos, bumbum sensação); e, claro, como vimos logo acima, o endosso das celebridades (se uma atriz faz um determinado exercício e alcançou um corpo-perfeito, o sujeito comum também pode - e deve - fazer o mesmo para formatar sua aparência corporal).

A circulação de um formato corporal e suas partes no espaço público e no ambiente midiático compõe um dos trunfos do discurso da boa forma, autorizando o que pode ou não circular. Em nosso corpus de análise, não há espaço para defeitos. No universo da beleza suprema, os defeitos são esquecidos, apagados. Ou aparecem de forma tímida, para mostrar o "antes" e o "depois" das leitoras que emagreceram e obtiveram outro formato corporal.

\footnotetext{
${ }^{147}$ Chamada de capa da revista Corpo a Corpo (edição n. 324).

${ }^{148}$ Matéria da revista Corpo a Corpo (edição n. 317, p. 33).

${ }^{149}$ Chamada de capa da revista Corpo a Corpo (edição n. 315).

${ }^{150}$ Chamada de capa da revista Boa Forma (edição n. 340).

${ }^{151}$ Chamada de capa da revista Corpo a Corpo (edição n. 322).

152 Chamada de capa da revista Corpo a Corpo (edição n. 321).
} 
O glúteo que pode circular faz parte da configuração imaginária do corpo-projeto. As atrizes, quando aparecem nuas ou seminuas no ambiente midiático, devem ostentar glúteos perfeitos. Qualquer formato diferente do parâmetro enaltecido pela mídia causa furor imediato. Dois exemplos midiáticos mostram a força da imagem do corpo feminino na mídia, especialmente quando ressaltam o glúteo de uma mulher famosa. Em janeiro de 2015, a atriz Paolla Oliveira foi um dos assuntos mais comentados nas redes sociais, como o Twitter, por aparecer de costas trajando apenas uma calcinha fio dental e sapatos de salto alto na minissérie “Felizes para sempre”, exibida pela Rede Globo de Televisão. Não é possível afirmar se houve ou não algum retoque digital para mascarar possíveis defeitos, mas a imagem era de um corpo perfeito, sem nenhuma imperfeição aparente. Uma imagem muito semelhante com as que circulam nas publicações impressas e digitais das novas dietas.

Em dezembro de 2017, uma outra imagem midiática, exposta por apenas 11 segundos, causou exaltação na mídia. No início do videoclipe "Vai malandra", a cantora Larissa de Macedo Machado, que adotou o nome artístico Anitta, aparece andando no que parece ser a rua de uma comunidade carente, trajando um curto short vermelho. A câmera põe em foco o glúteo e parte das coxas, deixando à mostra as celulites da cantora. Apenas um mês depois, o vídeo já havia alcançado mais de 130 milhões de visualizações no Youtube e, no Spotify, serviço digital de distribuição de conteúdo de áudio de vídeo, foi uma das músicas mais ouvidas em todo o mundo, uma marca inédita para uma artista brasileira. $\mathrm{O}$ assunto pautou jornais importantes no cenário jornalístico mundial, como o britânico The Guardian (Oliveira, 2017). O alvoroço em torno do videoclipe não se deu apenas pela celulite da cantora. Foi travada uma batalha na mídia sobre o empoderamento ou a objetificação da mulher em vídeos como o lançado por Anitta. 


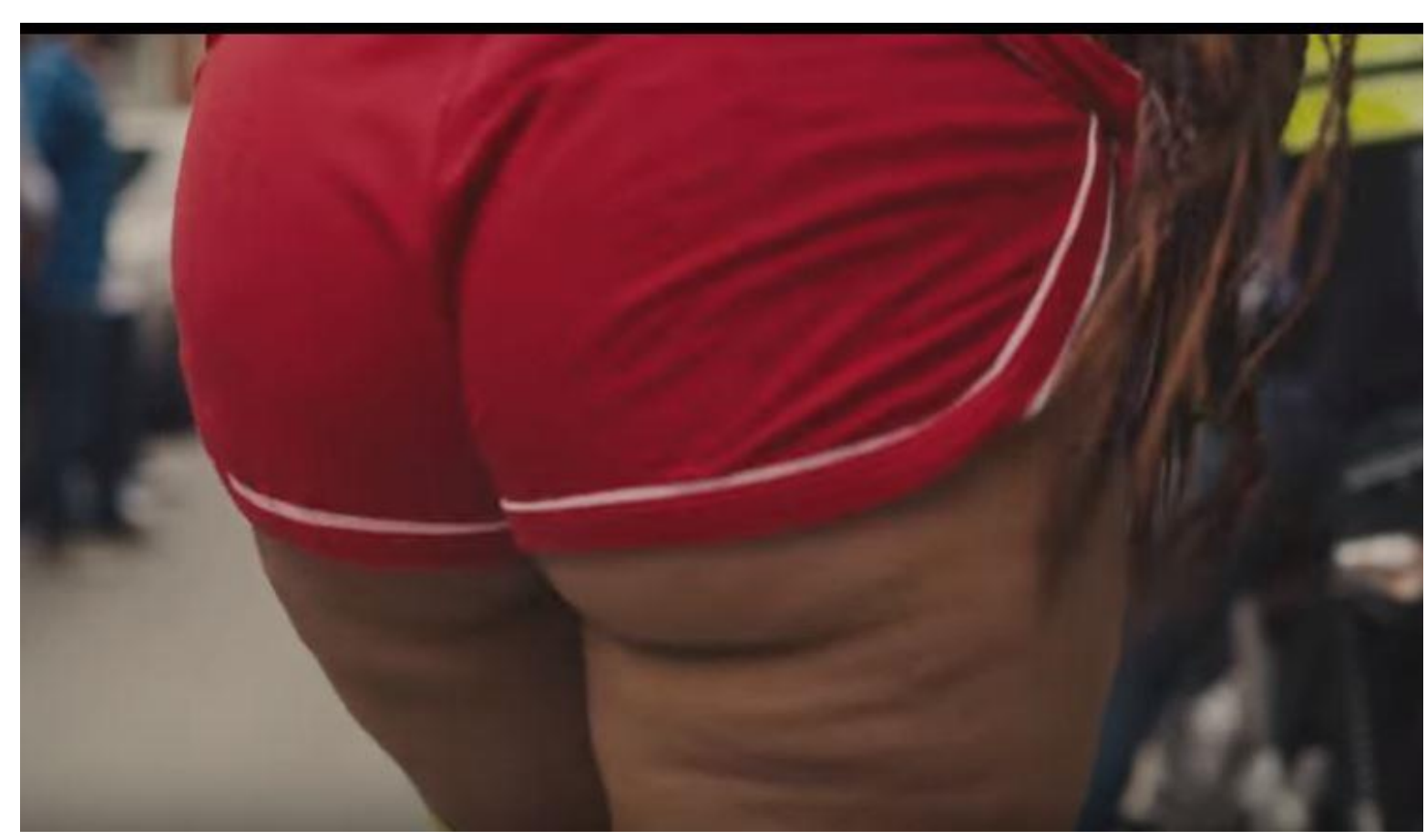

Figura 19. A cantora Anitta no início do videoclipe "Vai malandra"153

No caso específico do vídeo da Anitta, não pretendemos, neste trabalho, discutir questões relacionadas a temas como feminismo ou empoderamento feminino. Nossa reflexão recai sobre a imagem do formato corporal feminino e os sentidos provenientes dessa materialidade significante, tendo como recorte analítico o formato arquitetado de corpo que circula na ambiência midiática contemporânea. Em uma reportagem do Jornal O Globo (Celilute de Anitta gera debate sobre o corpo real), do qual contribuímos com nossa visão sobre a imagem do corpo feminino na mídia, pontuamos que o "corpo autorizado a circular no ambiente midiático é de uma beleza inigualável, e aquilo que está fora desse padrão não costuma ser aceito" (Brandão, 2017).

De forma sutil, Anitta foi corajosa ao quebrar esse padrão, mesmo que por meros 11 segundos. Porém, em se tratando de mídia e consumo, como ocorre com uma cantora que quanto mais aparece, mais vende, nada é por acaso. Praticamente tudo, no ambiente da mídia, é pensado e estruturado para vender, seja um produto, uma ideia, uma experiência. Mesmo que os responsáveis pelo vídeo tenham sugerido à cantora que mostrasse seu corpo sem retoques digitais, expondo um "defeito estético feminino", a sacada foi genial. Ela mostrou às mulheres que o corpo de uma celebridade (rica e famosa) também é um corpo parecido com o das

\footnotetext{
${ }^{153}$ Recuperado em 8 de janeiro de 2017, de https://www.youtube.com/watch?v=kDhptBT_-VI
} 
mulheres normais, não famosas, fazendo ressoar sentidos de naturalidade e identificação com o sujeito comum.

A medicina usa os seguintes termos para descrever aquilo que popularmente é conhecido como celulite: "paniculite, paniculose, lipoedema, mesenquimatose, fibro edema ginóide, paniculopatia, etc., mas apesar da impropriedade, sem dúvida, 'celulite' ganhou repercussão universal, tendo seu uso consagrado" (Ullmann et al., 2004, p. 187). "É algo realmente natural", disse um médico que também opinou sobre a performance da Anitta (Brandão, 2017). Após observar e analisar publicações impressas e digitais que fomentam a busca por um exemplar de beleza antinatural, não observamos em nosso corpus uma única imagem de uma celebridade exibindo celulite. Contudo, é uma afecção que acomete aproximadamente 95\% das mulheres (Ullmann et al., 2004). Ou seja, há um descompasso gritante entre os corpos do mundo real e a imagem dos corpos do universo midiático das novas dietas e boa forma.

A partir dessa constatação, podemos inferir que um dos fatores que alçaram o videoclipe de Anitta ao sucesso midiático foi, sim, a exposição do glúteo contendo celulite. Golpe de marketing? Provavelmente. Mas quantas celebridades não lucraram com a perfeição do corpoprojeto? Anitta mostrou que também é possível lucrar ao expor uma parte do corpo com imperfeições estéticas, justamente porque o sujeito contemporâneo não está acostumado, e podemos verificar isso nesta tese, a ver uma celebridade expondo os defeitos do seu corpo em escala mundial. Quando isso acontece, o impacto é instantâneo e eloquente. De certa forma, Anitta fez um gesto "autorizando" um formato de corpo, com defeitos estéticos prevalentes na maioria dos corpos reais, a circular em um espaço onde a imperfeição é impetuosamente repelida.

Ao longo do vídeo, Anitta aparece de frente, trajando biquíni, com um formato próximo ao do corpo-projeto. Mas aí já é outra história! A tão combatida celulite está lá, em um corpo de uma celebridade. Um corpo que, distante das alterações digitais, ostenta imperfeições estéticas reais.

\subsection{Expandir para lucrar (metáfora do elástico): "personal gestante", dietas e exercícios para antes e depois da gravidez (barriga ostentação)}


A geometria corporal instituída pela mídia pode ser notada em uma prática discursiva e econômica relativamente recente. Assim como em toda atividade lucrativa, o mercado das dietas está em constante expansão para angariar outras formas de sujeito, investindo em todas as frentes possíveis que possam gerar lucro na exploração da forma sujeito corpo-perfeito. É como funciona o mercado. Para entender essa lógica, poderíamos recorrer a economistas ou administradores, mas quem traça um panorama mordaz dessa estrutura é o jornalista e escritor italiano Saviano (2014). Ele equipara o momento atual do capitalismo a um elástico esticado à extensão máxima, próximo do ponto de ruptura. No princípio, explica Saviano, os recursos estavam disponíveis e o mercado estava pronto para ser invadido por qualquer nova mercadoria capaz de tornar nossa vida mais cômoda. "Quando você comprava, sentia ter dado um salto para um futuro melhor. Se você produzia, percebia a mesma dimensão. Hoje estamos próximos do ponto de ruptura. Todo nicho de mercado foi conquistado, toda necessidade, satisfeita" (Saviano, 2014, p. 79). Atualmente, os empreendedores recusam a saturação e esticam o elástico na esperança de que ele suporte mais um puxãozinho. Apenas um Mark Zuckerberg ${ }^{154}$ nasce a cada século, afirma Saviano, enquanto os outros são obrigados a uma guerra de posição para colocar bens e serviços que talvez durem o tempo de um bater de asas. Todos os bens - inclusive os produzidos pelo mercado das dietas - são obrigados a se submeter a regra do elástico.

Um exemplo de como o mercado das dietas tenta esticar o elástico para expandir sua atuação é a Formação Discursiva sobre o corpo-novo durante e após a gravidez. O corpo-novo não pode envelhecer, sofrer a ação do tempo ou as imposições de um evento biológico. Segundo Payer (2005), estamos diante de um flagrante da estreita relação entre a produção dos enunciados e a configuração da sociedade e de seus sujeitos. É o que denominamos forma sujeito grávida-perfeita. Caso a mulher contemporânea engravide, deve empenhar-se em retomar a aparência anterior à gravidez (ou até mais magra, bela e jovem):

\section{Recorte 29:}

Luciana Gimenez. 45 anos, dois filhos, barriga desenhada e pele de bebê com ioga e técnicas high tech ${ }^{155}$

Ana Hickman: corpão depois da gravidez ${ }^{156}$

Juliana Paes. 35 anos, 2 filhos, conta como perdeu os 16 quilos da gravidez ${ }^{157}$

Angélica. 41 anos, 3 filhos, revela sua receita de suchá detox ${ }^{158}$

\footnotetext{
${ }^{154}$ Mark Elliot Zuckerberg é um programador, empresário norte-americano e fundador do Facebook. É uma das pessoas mais ricas do mundo.

${ }^{155}$ Chamada de capa da revista Corpo a Corpo (edição n. 317).

${ }^{156}$ Chamada de capa da revista Boa Forma (edição n. 344).

157 Chamada de capa da revista Boa Forma (edição n. 334).

${ }^{158}$ Chamada de capa da revista Shape (edição n. 66).
} 
Fernanda Motta. Linda e sexy aos 34 anos, mãezona e louca por pilates e coxinha $^{159}$

Circuito barrigão. Já se foi o tempo em que a grávida devia substituir o exercício habitual pela hidroginástica ${ }^{160}$

Força para dar colinho ${ }^{161}$

O discurso do corpo-perfeito na pós-gravidez reverbera efeitos de sentidos também junto ao sujeito-leitor, como fica claro no recorte abaixo:

\section{Recorte 30:}

Samba na cara da sociedade com três filhos e esse corpinho! Ai, ai, ai... ${ }^{162}$

Os comentários dos sujeitos-leitores são em sua maioria encomiastas - derramam-se em elogios para as imagens do corpo-perfeito das celebridades preferidas. Não há espaço para observações infames. O "corpinho" a que se refere o leitor evoca sentidos de jovialidade e magreza. O "samba na cara" remete a efeitos de sentidos de "zombar" dos sujeitos-normais, o conjunto da sociedade com estilos de vida que dificultam a obtenção dos patamares de primazia exigidos pela ideologia das dietas e do corpo-perfeito (ou seja, a maioria esmagadora dos sujeitos da nossa sociedade).

Há também o endosso das celebridades, que faz funcionar no discurso o efeito de superação e realização. As celebridades, enfatiza Botton (2015), são mais velozes, mais fortes, mais criativas, mais ricas, mais belas, mais sensuais, mais jovens do que o cidadão comum. Suas realizações nos estimulam e nos seduzem, já que "o desejo de ser famoso é uma tentativa de fazer com que nossa dignidade seja respeitada em um mundo em que quase certamente não o será" (Botton, 2015, p.154). Alinhado ao pensamento de Botton, acrescentamos que além da necessidade de ser respeitado, o sujeito-comum busca acima de tudo aparecer. É preciso sair do ostracismo, ser visto (mais do que ver), estar exposto o tempo todo, participar da visibilidade exacerbada de nossa época midiática. Não basta ser, é preciso aparentar. Aparecer é preciso, viver não é preciso. "A sociedade da informação exige de seus membros uma crescente visibilidade. Em princípio, todos os indivíduos são obrigados a estratégias de encenação" (Kamper, 2016, p. 77). As celebridades, através das realizações difundidas pela mídia, parecem viver em um olimpo, em um universo onde os deuses e deusas midiáticos vivem em estado de êxtase e luxúria constantes, onde as agruras da vida parecem não subsistir.

\footnotetext{
${ }^{159}$ Chamada de capa da revista Corpo a Corpo (edição n. 324).

160 Matéria da revista Corpo a Corpo (edição n. 317, p. 64).

161 Matéria da revista Boa Forma (edição n. 345, p. 28).

162 Comentários publicados na revista Shape (edição n. 67).
} 
E a fama midiática está atrelada ao corpo. Nesse sentido, a fama se revela no corpo, uma vez que "os sujeitos textualizam seu corpo pela maneira mesma como estão nele significados, e se deslocam na sociedade e na história: corpos segregados, corpos legítimos, corpos tatuados" (Orlandi, 2012b, p. 19), corpos-perfeitos, corpos-magros, corpos-projetados, corpos(re)fabricados. Nesse espaço discursivo/midiático, se o sujeito é famoso, sua fama se faz através de seu corpo. Não são apenas suas ideias ou ideais que estamparão seus nomes no universo midiático, mas essencialmente seus rostos e corpos. Pensando nos recortes acima, não basta ser mãe, é impreterível ter a barriga desenhada, a pele tão lisa e brilhante quanto a de um bebê; ser linda e sexy, louca por pilates (exercícios) e, além disso, se dar ao luxo de ingerir frituras sem engordar. Esse discurso contraditório provoca efeitos ambíguos ao sugerir que a mulher pode ingerir alimentos altamente calóricos e, ao mesmo tempo, emagrecer. A contradição parece agir como um pêndulo, situando o sujeito em uma forma de funcionar/existir e simultaneamente deslocando-o para diferentes condições de existência. O agenciamento das subjetividades não ocorre de forma completa, argumenta Gregolin (2017, pp. 23-24), mas em "um permanente entrelaçamento móvel entre as forças de territorialização e as de desterritorialização, ambas agindo e provocando contradições”.

E a expressão "corpão", apesar de parecer aumentar a noção semântica de "corpo" para algo relativamente maior do que é, evoca efeitos de sentidos contraditórios ao redefinir a noção de corpo. O sufixo "ão" atrelado à palavra corpo não se refere a um corpo de formato grande, mas altera a noção semântica de corpo para aquilo que apresenta alta voltagem ou apelo sexual, o que em inglês é designado sex-appeal. Apesar de ser magro, o corpão da forma sujeito mãecelebridade não sucumbiu às alterações da maternidade e manteve sua carga erótica, sendo um arquétipo a ser adotado pela mulher/mãe-comum (especialmente àquelas que engravidaram ou pensar em engravidar).

O corpo na/da atualidade deixou de ser a identidade de si para se tornar, na visão de Le Breton (2003), um kit, uma soma de partes destacáveis disponíveis a todo tipo de modificação proporcionada pela indústria do design corporal. Se essa indústria é composta pela soma de diversas atividades como dietas, exercícios e cirurgias estéticas, as publicações impressas e virtuais voltadas para boa forma dão publicidade e legitimidade a essas alterações corporais.

Além das partes do corpo mencionados no recorte acima, uma das reportagens que circula em nosso corpus argumenta que, além do glúteo, o abdômen sequinho está "ganhando cada vez mais terreno na lista de prioridades femininas" ${ }^{\text {163 }}$. Vejamos alguns exemplos:

\footnotetext{
163 Matéria da revista Corpo a Corpo (edição n. 324, p. 87).
} 


\section{Recorte 31:}

Abdômen rasgado. É tendência, é sexy e é ousado ${ }^{164}$

BARRIGA ZERO. Dicas de alimentação para mandar a pochete embora $^{165}$

Barriga dos sonhos ${ }^{166}$

Conquiste sua barriga chapada ${ }^{167}$

Cardápio termofuncional. Seca $6 \mathrm{~kg}$ e afina $4 \mathrm{~cm}$ na barriga em um mês ${ }^{168}$

Zero barriga. Perca 5 centímetros de cintura com nosso cardápio 169

Barriga chapada. Perca 4 kh em um mês com a dieta das castanhas ${ }^{170}$

Barriga TOP. O treino da australiana responsável pelos antes e depois mais incríveis. Tá bombando no Instagram! ${ }^{171}$

BARRIGA SECA JÁ! Circuito Aero + Local ${ }^{172}$

Cintura fina em um pulo! Estratégias e alimentos que derretem a gordura abdominal ${ }^{173}$

A formação ideológica do corpo-projeto direcionada às mulheres é enfática ao cristalizar, através das formações discursivas homogeneizantes, dizeres a respeito dessa parte do corpo feminino. Na atualidade, definitivamente a mídia escolheu a cintura fina e a barriga isenta de gordura como sinônimo de feminilidade e sensualidade. Não faltam adjetivos para enumerar as características e qualidades do formato abdominal aceito na atualidade para essa parte do corpo feminino. As denominações do formato do abdômen atuam discursivamente de forma semelhante aos nomes das dietas que analisamos anteriormente. Elas conferem ao formato da barriga efeitos de força, robustez, energia e vigor. Os "nomes próprios" promovem a constituição de sentidos dominantes ao indicarem a configuração e a dimensão exata da barriga (barriga chapada, dos sonhos, fina, negativa, rasgada, sarada, seca, top, trincada, zero, etc.). Por conseguinte, outros padrões são silenciados ou ridicularizados através de sentidos irônicos atribuídos à gordura abdominal (pochete, pneuzinho, gordurinhas ou dobrinhas).

\footnotetext{
164 Matéria da revista Boa Forma (edição n. 343, p. 102).

165 Matéria da revista Boa Forma (edição n. 345, p. 12).

${ }^{166}$ Chamada de capa da revista Women's Health (edição n. 83).

${ }^{167}$ Chamada de capa da revista Women's Health (edição n .86).

168 Chamada de capa da revista Corpo a Corpo (edição n. 314).

169 Chamada de capa da revista Boa Forma (edição n. 342).

${ }^{170}$ Chamada de capa da revista Dieta Já! (edição n. 247).

${ }^{171}$ Chamada de capa da revista Boa Forma (edição n. 347).

172 Chamada de capa da revista Women's Health (edição n. 79).

${ }^{173}$ Chamada de capa da revista Boa Forma (edição n. 346).
} 
Novamente, as sequências discursivas acima reforçam uma de nossas teses sobre o texto midiático das dietas e boa forma: estamos diante de textos publicitários, que incitam e chamam a atenção do sujeito-leitor pelas artimanhas empregadas na construção dos enunciados. O verbo no imperativo se faz presente, convocando a mulher a afinar a cintura: "mande a pochete embora", "conquiste sua barriga chapada", "perca 5 centímetros de cintura”. Assim como os defeitos, a dúvida também é abafada. Não há, na formação ideológica e discursiva do corpoprojeto, espaço para outro tipo de corpo: portanto, não há lugar para outro formato de abdômen que não personifique a norma estabelecida pela mídia.

O discurso das dietas é construído e sedimentado sobre axiomas que indicam direções únicas, cristalizando aspectos culturais e homogêneos, sem, contudo, detalhar a origem de algumas sentenças. Um exemplo é o enunciado do recorte acima: “Abdômen rasgado. É tendência, é sexy e é ousado". Os argumentos são poderosos e incidem sobre a mulher ao indicar e impor o padrão de uma parte do corpo, atribuindo a essa configuração efeitos de feminilidade e sexualidade "sexy e ousado", além de configurar uma tendência. Para os profissionais de marketing, uma tendência é um direcionamento ou uma sequência de eventos com certa força e estabilidade que revelam, de certa forma, como será o futuro (Kotler e Keller, 2012). Ao tomar para si o poder de instituir o que é ou não tendência, a mídia geometriza o corpo e estipula qual arquétipo deve ser adotado para cada parte do corpo feminino. Mais um exemplo:

\begin{abstract}
Recorte 32 ${ }^{174}$ : PEITO DA MODA.

Pensando em colocar silicone? Pense de novo. Seios naturais são uma tendência - as atrizes Jennifer Aniston e Jennifer Lawrence e a princesas Kate Middleton são algumas referências. Para quem tem pouco busto, aumentar e, ainda assim, ficar natural, é possível. "Mas é importante escolher o formato da prótese de acordo com a largura e a altura do tórax", avisa a cirurgiã plástica Roseli Cardinali, de São Paulo.

O melhor exercício para... manter os seios empinados. Acredite! É possível dar aquela turbinada apenas com exercícios físicos, sem precisar recorrer à cirurgia plástica. Quer saber como? Então confira a atividade que mais trabalha essa região do corpo ${ }^{175}$
\end{abstract}

Como um dos atributos do discurso das dietas e boa forma é o imperativo da velocidade, as tendências mudam frequentemente. Conforme já relatamos, o discurso midiático das dietas trabalha discursivamente para promover, simultaneamente, efeitos de unidade dos sentidos (apontando tendências singulares), e efeitos de inovação e mudança (recriando e reformulando

\footnotetext{
${ }^{174}$ Matéria da revista Women's Health (edição n. 82, p. 14).

175 Matéria da revista Dieta Já! (edição n. 242, p. 24).
} 
padrões estéticos e modelos imagéticos). O formato dos seios deve obedecer às transformações naturais impostas pelo envelhecimento? Ou deve ser "empinado" ou remodelado através de cirurgias estéticas? Grande ou pequeno? Os seios devem ser preenchidos com próteses de silicone? ${ }^{176}$ Qual o padrão a ser seguido? Estés (2014) compara o corpo a um planeta que, como qualquer paisagem ou superfície, é vulnerável ao excesso de construções, retaliações, a se sentir isolado e alijado. A circulação incessante de enunciados sobre os formatos corporais da moda "leva os sujeitos a viverem uma tensão constante entre as oportunidades infinitas de singularização e a insistência poderosa nos modelos identitários (subjetividades-clone)" (Gregolin, 2007, p. 21).

Aqui entra em cena a superficialidade com que a mídia (e o discurso das dietas e boa forma) aborda certos temas. Ao afirmar que a tendência é ostentar um abdômen "rasgado", a mídia sintetiza dizeres e valores sobre o ideal de beleza feminino sem, contudo, deixar claro quem é o responsável em definir o padrão adotado como referência estética. Esse exercício de apontar singularidades é exercido pela própria mídia. No discurso midiático das dietas, isso nos parece evidente: a revistas (que também são produtos midiáticos) apresentam os bens e serviços relatados em seus textos como objetos e procedimentos que ajudarão o sujeito-leitor a alcançar o corpo-perfeito. Tudo está à venda. O sujeito-leitor compra a revista ou acessa o site, é apresentado as últimas novidades para perder peso e delinear o corpo e consome os produtos relatados nos textos e destinados a essa finalidade. Do início ao fim, o discurso texto midiático das dietas e boa forma parece ter como único objetivo fomentar um grande comércio para o sujeito-mulher tentar, a todo custo, alcançar o corpo-projeto.

Com perspicácia, Gregolin (2007) aponta que a "mídia é o principal dispositivo discursivo por meio do qual é construída uma 'história do presente' [...] que formata a historicidade que nos atravessa e nos constitui" (p. 16). Se o discurso sobre a corporeidade feminina tem uma história, uma memória, as "partes" desse mesmo corpo também são impregnados por uma história e uma memória. Diminuir a cintura não é algo novo na história da humanidade. Os primeiros espartilhos, peça usada para comprimir o abdômen e afinar a cintura, surgiram no século XVI e eram feitos com esteios rígidos de metal ou barbatanas de baleia. Relatos do século XVII mostram que mulheres se amarravam e se apertavam com tanta

\footnotetext{
176 O preenchimento e o esvaziamento dos corpos para adequá-los a um novo padrão estético foi objeto de um artigo (no prelo) que propõe uma reflexão sobre as relações entre o corpo biológico (coagido pela exortação à visibilidade) e o corpo-perfeito que circula no ambiente midiático, partindo do caso amplamente divulgado pela mídia do problema de saúde da modelo Andressa Urach após uma aplicação de hidrogel. O título do trabalho é "O processo iconofágico na relação entre o corpo feminino e as imagens midiáticas: o caso Andressa Urach" (Sanches e Baitello, no prelo).
} 
força para conseguirem um contorno magro, suportando qualquer dor autoinfligida para terem uma cintura esguia (Foxcroft, 2013). Os espartilhos foram usados desde o começo do século XVI até o fim do século XIX, mas no século XIX começou a moda dos espartilhos amarrados que, usados desde a puberdade, comprimiam as costelas, forçando pulmões, fígados e coração a serem deslocados e apertados, além de prejudicarem o funcionamento dos intestinos (Hecht, 2009). Qual a diferença entre a mulher que usava espartilhos e a mulher dos dias atuais, que adere a outros tantos sacrifícios para afinar a cintura?

\begin{abstract}
A mesma mulher que lamenta pelas garotas de espartilho do passado pode muito bem ir à academia de ginástica cinco vezes por semana para fazer cem flexões sobre uma bola suíça e mais uma hora de aeróbica. Provavelmente ela cuida muito de sua dieta, come alimentos que foram privados de vários elementos que sustentam a via, e assim mantém seu corpo com o mínimo de gordura. A estrutura de ossos de baleia sumiu de baixo do vestido, mas agora suas costelas aparecem através do tecido! [...] Então, quem é mais louca, a cultura que fazia as mulheres amarrarem seus corpos ou a nossa? (Hecht, 2009, pp. 09-10).
\end{abstract}

O abdômen feminino apresenta uma forte carga simbólica. É justamente ali que se encontra o útero, órgão atrelado à vida, à geração de uma nova vida. E, como um fenômeno biológico e natural, ao ficar grávida seu abdômen se expande durante os noves meses do desenvolvimento do feto.

\begin{abstract}
Aos vinte e poucos anos, tive dois bebês. Fiquei GRANDE. Quando ganhei dezenove quilos, dos quais apenas uns três correspondiam ao bebê, meu médico me passou um severo e paternal sermão sobre como eu estava engordando. Na verdade, ele me disse, com grande confiança, que eu "incharia como um balão" e que lutaria para perder peso se insistisse em amamentar. Ancas estreitas e barriga côncava: nunca mais, ele disse. Em vez disso, pareia que eu podia de fato me transformar em uma mulher - horror - o que, quase certamente, não era a forma desejada da eterna garota, mesmo entre clínicos gerais de província (Foxcroft, 2013, p.17).
\end{abstract}

Aqui há uma tentativa da formação ideológica das dietas e do corpo perfeito de apagar os sentidos provocados por um fator biológico: quando a mulher está vivenciando o período gestacional, seu corpo tende a sofrer modificações corporais. Inevitavelmente, ela irá engordar. Seu abdômen será esticado e aumentará de volume, mas essa parte do corpo da mulher tão freneticamente atacado pela ideologia da magreza faz circular sentidos dominantes de que, na atualidade, a mulher não pode sucumbir as alterações naturais causadas pelo período gestacional. Novamente, podemos observar a mídia operando como um dispositivo discursivo 
para construir uma história do presente sobre a gravidez, articulando e emanando sentidos sobre a forma corporal da gestante.

A ideologia da magreza e a forma sujeito grávida-perfeita é enfática: a mulher deve ter uma barriga "tanquinho, sequinha, desenhada, definida", mesmo após a gravidez. Ela deve manter-se magra em qualquer situação ou idade; nada pode atrapalhar o formato do seu corpo. Se ganhar uns quilos a mais por conta da gravidez, deve recrudescer na tentativa de se livrar dos efeitos indesejados e renovar a aparência:

\section{Recorte 33 ${ }^{177}$ :}

Gerar uma vida é tão incrível que a gente acaba relevando os efeitos colaterais. No fim das contas, me sinto mais bonita do que antes

O que deveria ser natural passa a ser "efeito colateral" do ato de engravidar. Esse discurso também faz ressoar ecos da ideologia do novo e da novidade:

\footnotetext{
Recorte $34^{178}$ :

“A gravidez está passando muito rápido! Torço para que a Vicky venha na hora certa e com muita saúde. E, quando isso acontecer, também nascerá uma nova Bella", diz a musa fitness, que durante toda a gestação não parou de se exercitar
}

Poderíamos fazer um gesto de leitura de que a "nova Bella" será uma nova mulher frente ao desafio de cuidar de seu filho recém-nascido. Mas, como os sentidos deslizam por efeito metafórico, ao abarcar os enunciados "mais bonita do que antes", "durante toda a gestação não parou de se exercitar", o surgimento de uma nova mulher (a nova Bella) é um discurso que também remete a sentidos de um corpo novo, melhor e aprimorado em sua aparência. A forma sujeito grávida-perfeita permite ao mercado das dietas possibilidades lucrativas com a edição de livros voltados para as práticas de exercícios durante a gravidez (dois exemplos são os livros Grávida em boa forma: seu guia de exercícios e dieta para antes e depois do parto e Pilates para grávidas), roupas específicas para atividade física durante a gestação, cosméticos e alimentos, além de profissionais como o "personal gestante".

\footnotetext{
177 Matéria da revista Boa Forma (edição n. 345, p. 28).

178 Matéria da revista Boa Forma (edição n. 345, p. 28).
} 


\subsection{Efeitos de completude: repetidas histórias de perfeição materializadas no corpo- imagem (corpo-celebridade)}

O discurso midiático das novas dietas, atrelada à Formação Discursiva do corpo-projeto, é um fenômeno dinâmico, vivo, complexo, compostos por múltiplos cenários que se desdobram em milhares de facetas, possibilitando uma infinidade de leituras possíveis. Podemos investigar, nas arestas desse discurso, algumas características comuns e subjacentes a esse fenômeno, àquilo que dá sustentação a essas relações de sentido, um discurso organizado e organizador cuja força se dá pela repetição, como vimos anteriormente, de imagens tecnicamente produzidas, mas também de enunciados, construções linguísticas de cunho publicitário/jornalístico.

Analisar um discurso, teoriza Gregolin (2007, p. 15) "significa tentar compreender a maneira como as verdades são produzidas e enunciadas". Para exemplificar esse processo discursivo que faz da repetição uma arma na construção de axiomas, de juízos que parecem ser incontestáveis, selecionamos quatro publicações. A ideia é mostrar como o mesmo discurso (e sua materialidade significante, composta por enunciados e imagens) se repete e faz ecoar efeitos de sentidos que apontam, se não para um único caminho, para um conjunto de artifícios simbólicos e imagéticos presentes nas formações ideológicas do projeto de corpo perfeito das mulheres que tiveram filhos e conseguiram formas corporais invejáveis após a gravidez. A narrativa midiática explora vários aspectos, reforçando os sentidos sobre o corpo-perfeito das celebridades que estampam a capa das quatro publicações escolhidas (que denominaremos nos recortes a seguir de Revista 1, Revista 2, Revista 3 e Revista 4).

\footnotetext{
Recorte 35:

Revista 1: Letícia Birkheuer. Loira, linda e magra!

Revista 2: Dona de uma barriga chapada, pernas torneadas e uma silhueta maravilhosa. Esta é a Angélica.

Revista 3: Nesse corpão, agora habitam a Ana mulher, a profissional e a mãe.

Revista 4: Dois filhos e um corpão, Juliana Paes é mesmo um fenômeno! (grifos nossos)
}

Após desfilar elogios aos corpos esculturais, os enunciados convocam o sujeito-leitor a conhecer a rotina e a trajetória das celebridades na conquista do corpo-perfeito após a gravidez. Os efeitos resultantes desses discursos projetam as celebridades ao posto de modelos (não apenas de beleza corporal), mas de vida, perseverança, atitude e dinamismo. Referências a 
serem copiadas pela mulher comum, seja pela inveja ou admiração, além de um processo de identificação suscitado pelo discurso e materializado na linguagem.

\section{Recorte 36:}

Revista 1: É isso o que a maioria das mulheres deseja. E a atriz Letícia Birkheuer tem esse perfil. Ficou com invejinha?

Revista 2: A cada ano que passa ela fica ainda mais bonita e segura de si. Afinal, são muitos aprendizados que a apresentadora faz questão de seguir para cuidar de seu corpo e bem-estar. Aprenda com ela!

Revista 3: A vida de Ana Hickman daria uma bela história de amor. Ela é movida pela paixão - para alcançar o sucesso profissional, ser mãe ou mesmo reconquistar o corpão de antes da gravidez. A intensidade dela é contagiante! Quer ver? [...]

Como chegou lá? Vem descobrir.

Revista 4: Mas, como qualquer mulher, Juliana precisou dar duro para recuperar a silhueta depois das gestações. (grifos nossos)

"É isso o que a maioria das mulheres deseja", impõe um dos enunciados. "Isso" e não "aquilo": a pluralidade não faz parte desse enredo. O sujeito-mulher não pode desejar outra coisa senão aquilo que, segundo o discurso da mídia, a maioria das mulheres deseja, mas que no fundo sabemos que é imposto pela própria mídia. Relembremos Barber (2003): os desejos e as necessidades sobre as quais prosperam os mercados são engendrados e moldados por estes mesmos mercados.

Quando o enunciado reforça que "a maioria das mulheres deseja" um corpo escultural como o de uma celebridade, há um processo imaginário de inserção do sujeito-leitor na mesma Formação Discursiva. Se a maioria das mulheres deseja algo, a leitora também é inserida nesse grupo e arrastada a desejar as mesmas coisas. Outro sistema imaginário de identificação ocorre quando os enunciados ressaltam que uma celebridade, "como qualquer mulher", conseguiu fazer isso ou aquilo. Em um jogo discursivo, os efeitos desse discurso promovem um nivelamento tanto da leitora comum quanto da celebridade ao mesmo patamar, cessando as diferenças econômicas, sociais, de disponibilidade de tempo e dinheiro, entre tantas outras diferenças, que separam de forma abismal as celebridades da mulher comum. O caldeirão de sentidos, que exalam do texto midiático das dietas e boa forma, ao direcionar agora seus tentáculos para a gravidez, busca mais uma vez fundar uma discursividade que inscreve/escreve formulações sobre a mulher contemporânea, em especial, a mulher grávida.

Os enunciados acima estão ancorados ainda em um aspecto primordial do ser humano: “o sujeito é desejante em virtude da sua incompletude" (Vinhas, 2011, s/p). A incompletude, aponta Orlandi (2005, p. 114), “é o indício da abertura do simbólico, do movimento do sentido 
e do sujeito, da falha, do possível”, uma vez que "o discurso é sempre incompleto assim como são incompletos os sujeitos e os sentidos" (p. 113), uma vez que o todo, a totalidade "seria como algo da ordem do impossível” (Kamper, 2016, p.58):

Se o sentimento de "unidade" permite ao sujeito identificar-se, por outro lado, sem a incompletude e o consequente movimento haveria asfixia do sujeito e do sentido, pois o sujeito não poderia atravessar, e não seria atravessado, pelos diferentes discursos já que não poderia percorrer os deslocamentos (os limites) das diferentes formações discursivas. O Outro (e os outros) é o limite mas também é o possível (Orlandi, 2011, p. 79).

A formação discursiva presente no discurso midiático das dietas já parte do pressuposto de que o sujeito-leitor-mulher é incompleto, deficiente, no sentido de não possuir ou apresentar as características hiperfísicas promulgadas pela mídia. A falta e a incompletude se materializam, desta forma, na linguagem e no corpo. A relação entre a incompletude (do sujeito) e a suposta completude (oferecida pelo discurso da boa forma) é tecnicamente trabalhada pelos editores e os profissionais da comunicação que atuam nesse tipo de publicação. O discurso é formulado de modo a direcioná-lo aos medos e anseios da mulher na atualidade, como o medo de engordar e a obsessão por retomar o mais rápido a melhor forma física possível após a gravidez; o que, em muitos casos, é praticamente impossível. Deste modo, o discurso busca enfatizar que as parturientes famosas voltaram a ter um corpo magro e definido logo após o nascimento dos seus filhos:

\section{Recorte 37:}

Revista 1: E por falar no filho, a estrela conta que engordou $22 \mathrm{~kg}$ na gestação [...] "Seis meses depois já estava no meu peso", revela a estrela.

Revista 2: [...] aos 41 anos, desfila com seus 56 quilos muito bem distribuídos nos 1,64 $\mathrm{m}$ de altura, mesmo após a gestação de seus três filhos.

Revista 3: Ela lembra que, depois de ter ganhado 30 quilos na gravidez, o quadril foi o primeiro a voltar à medida anterior [...]. A batalha foi grande, mas em sete meses ela já pesava 69 quilos de novo.

Revista 4: "Engordei 16 quilos em cada gravidez e tive de correr atrás" [...] Aos 35 anos, Juliana levou nove meses para voltar à forma e diz que deseja eliminar 2 quilinhos. (grifos nossos)

A mulher contemporânea é interpelada a realizar incessantes investimentos e movimentos de superação para formatar seu corpo aos paradigmas estabelecidos pelo corpoprojeto. O recorte acima reforça os sentidos que permeiam o discurso das dietas e recaem sobre a mulher atualmente: quem engorda precisa emagrecer. Mesmo após a gestação de um ou mais 
filhos: engordou? EMAGREÇA. As celebridades conseguem, e você também! Basta conhecer os "segredos" ou "passos" de cada uma e colocá-los em prática:

\section{Recorte 38:}

Revista 1: E aí, dá para seguir os passos da bonita, né? Ela não faz nada além do que você possa fazer também. Que tal começar ainda hoje?

Revista 2: O segredo? Na verdade, são vários! Mas eles se resumem em uma combinação de alimentação supersaudável e atividade física.

Revista 3: A batalha foi grande, mas em sete meses ela já pesava 69 quilos de novo e, em um ano, vestia a mesma calça jeans.

Revista 4: E, apesar de dizer que come um pouco de tudo, como fazem as francesas, esta mulher alegre e cheia de energia tem muitos segredos. A atriz prioriza um cardápio sem lactose e sem glúten e investe nos alimentos funcionais e nos sucos detox.

Os enunciados fazem reverberar efeitos de sentidos ancorados em uma permanente contradição: ao mesmo tempo que são seres que habitam um outro universo, o das celebridades, com recursos financeiros suficientes para arcarem com os altos custos dos procedimentos estéticos de lapidação da aparência corporal, a narrativa sugere que tudo está disponível e ao alcance de todos. O sujeito, incompleto e interpelado pelo texto midiático das dietas e boa forma, procura a completude na própria alteração corporal, no emagrecimento através de dietas milagrosas ou nas diversas práticas para perder gordura. Almeja a completude espelhando-se em uma imagem, no outro do corpo, um outro insuperável, intransponível. O outro do corpo, enquanto imagem, não passa de um projeto platônico de corpo, inatingível pela sua própria condição de inexistência e incompatibilidade com o mundo real. Enquanto imagem, sua existência está confinada ao mundo transcendente do discurso midiático das dietas e boa forma. Em um movimento interminável, sujeito e discurso realizam-se juntos, em novidades e modismos que imprimem ao corpo do sujeito-mulher um "estar no mundo", a aceitação programada e possível pela via da aparência física.

E a mídia trabalha repetidamente os discursos das dietas e boa forma convocando e instigando o sujeito-leitor a conhecer e a compartilhar histórias de completude, perfeição, bemestar psíquico, material (econômico) e físico (corpo-perfeito) das celebridades midiáticas. Para isso, o sujeito-leitor é incitado a desejar o corpo-projeto, já que uma vida perfeita se materializa em um corpo igualmente perfeito. "Ficou com invejinha?", questiona um dos enunciados. "Aprenda com ela", ordena o texto de outra publicação.

A completude parece se materializar nas medidas corporais, postadas ao lado das imagens perfeitas; ao fato de que elas não envelhecem com o passar dos anos, mas estão cada 
dia mais bonitas; e também pelo fato de alcançarem o sucesso profissional ao mesmo tempo em que se comportam como esposas e mães maravilhosas, são autoconfiantes, seguras de si, e reconquistaram o "corpão" que já tinham mesmo após o processo gestacional.

Nesse enredo discursivo, não há espaço para falhas, dúvidas, medos, anseios, separações, quebras (físicas ou psicológicas), muito menos para olheiras, rugas, manchas, estrias, gorduras salientes, barrigas grandes, seios caídos, celulite. O corpo-projeto, metafísico, não aceita erros, não está sujeito às falhas que corrompem o imaginário de uma beleza suprema. Também não aceita a ineficiência daqueles que sucumbem as contingências da vida cotidiana e deixam manifestar, no seu próprio corpo, o solecismo e a imperfeição.

Os enunciados fornecem de maneira veemente os segredos de cada celebridade para atingir a plena realização e satisfação em todos os aspectos da vida, em especial com o design corporal. As publicações das dietas e boa forma atuam como uma Caixa de Pandora: diante dos males do mundo e da banalidade da vida cotidiana, a esperança está na possibilidade de espelhar-se naqueles que alcançaram sucesso, fama, poder, completude. A esperança midiática do corpo-perfeito não é possível de ser apanhada; como não existe, nunca será libertada. Os efeitos de sentidos dos enunciados reverberam um caminho a ser seguido pelo sujeito comum, com base nas histórias de superação das celebridades, para alcançar o corpo-perfeito oriundo de uma vida mágica, de saúde e bem-estar.

Os passos para almejar o corpo-projeto se resumem a fazer isso ou aquilo, pois tudo é acessível e descomplicado. Os enunciados fazem ressoar efeitos de sentidos de disponibilidade e acessibilidade: não há nada que as celebridades fazem que o sujeito-comum não possa fazer, ou não esteja disponível e ao alcance de todos, quando sabemos que as celebridades possuem recursos financeiros suficientes para subsidiar os tratamentos de alto custo vedados a grande maioria das mulheres.

As quatro narrativas anteriores são seguidas por imagens que praticamente se repetem. Produzidas, maquiadas, com roupas de banho (biquíni, maiô) ou roupa de ginástica, as imagens dos corpos exuberantes das personagens deixam a barriga à mostra, sempre em poses sensuais. Os cabelos estão perfeitamente cuidados, e a pele é lisa e exibe um brilho e uma textura homogêneos, de uma alvura quase absoluta e um aspecto prodigioso, divino, cujas qualidades excedem o mais perfeito espécime humana.

São efeitos de sentidos que acabam por ditar como a mulher contemporânea deve se comportar em relação ao seu corpo mesmo diante de um evento biológico como a gravidez, ou seja, como ela deve se significar através de um corpo que se textualiza, significa, tem sua carne retrabalhada, reconfigurada por agentes ideológicos, ao funcionamento da ideologia. Ainda 
sobre enunciados que contam as histórias de superação das celebridades que engravidaram, um caso curioso é a construção da trama discursiva calcada na repetição do discurso, materializada nas estruturas linguísticas praticamente idênticas (os textos aparecem nas mesmas revistas 1, 2, 3 dos recortes acima). As publicações 1 e 2 enfatizam que as celebridades alcançaram a fama, o sucesso e o corpo-perfeito porque possuem segredos que, com generosidade, compartilham com as leitoras:

\section{Recorte 39:}

\section{Revista 1:}

$1^{\circ}$ segredinho: Tratamento estético, sim!

$2^{\circ}$ segredinho: Amamente!

$3^{\text {o }}$ segredinho: Coma em casa

$4^{\circ}$ segredinho: Seja saudável

$5^{\circ}$ segredinho: Tenha um cardápio caseiro

$6^{\circ}$ segredinho: Sem neurose

$7^{\circ}$ segredinho: Beauty aliados

\section{Revista 2:}

$1^{\circ}$ segredo: Shake de proteína

$2^{\circ}$ segredo: Berries no cardápio

$3^{\circ}$ segredo: Carbo com atenção

$4^{\circ}$ segredo: Restrição ao glúten

$5^{\circ}$ segredo: Doce? Apenas cacau $70 \%$

$6^{\circ}$ segredo: Dá-lhe fibras e nozes

$7^{\circ}$ segredo: Chá anti-inchaço!

$8^{\circ}$ segredo: Salada, sempre!

$9^{\circ}$ segredo: Detox pós-pecado

$10^{\circ}$ segredo: Malhação amiga

A revista 2 traz ainda efeitos do novo e da novidade, quando a celebridade ressalta, no $4^{\text {o }}$ segredo (restrição ao glúten), que gosta "de experimentar as novidades saudáveis que surgem". O novo e a novidade, conforme mostramos no capítulo anterior, permeia o discurso contemporâneo das dietas e boa forma. $\mathrm{O}$ endosso da celebridade reforça sentidos sobre a inevitabilidade de acompanhar os novos hábitos alimentares para manter o corpo esguio. Hábitos que são renovados constantemente pelo discurso das dietas - aquilo que era novidade passa a ser rapidamente substituído por outra forma de se alimentar. O que era bom de ser ingerido até pouco tempo atrás passa a ser o vilão que agora deve ser combatido. Não há consenso e muito menos bom senso das publicações em orientar o sujeito-leitor a alimentar-se adequadamente, perdendo a grande oportunidade de serem responsáveis e protagonistas na 
melhoria da saúde da população. Justamente porque a sobreposição de novos elementos em ritmo frenético é o motor que gira a engrenagem discursiva das dietas e boa forma, garantindo que o leitor seja indefinidamente fisgado pelas novidades que prometem mais benefícios em relação às anteriores, de forma sucessiva e incessante.

A revista 3 usou a mesma trama discursiva, substituindo apenas o "segredo" pelo “amor". Love Story é o título do texto, que enfatiza o quanto a vida da celebridade é espetacular, digna de uma "bela história de amor". E para alcançar o corpão depois da gravidez, o segredo da celebridade é "amar":

\author{
Recorte 40: \\ Revista 3: \\ AMOR à malhação \\ AMOR ao corpo \\ AMOR aos tratamentos estéticos \\ AMOR de mãe \\ AMOR a boa comida \\ AMOR ao trabalho
}

O "amor" da celebridade pelas diversas esferas da vida remete aos efeitos de plenitude, satisfação e sucesso. O segredo para ostentar e exibir um corpo perfeito é amar o próprio corpo - e tudo aquilo que permite mantê-lo na forma desejada - além de amar seus filhos, o trabalho e a boa comida. Os enunciados refletem ainda efeitos de completude quando dão ênfase à capacidade das celebridades em abarcarem todos os papéis que competem à mulher moderna: "Nesse corpão, agora habitam a Ana mulher, a profissional e a mãe". Todos os papéis são desempenhados da melhor forma possível, já que a mulher-celebridade está sempre segura de si. Elas são modernas, bonitas, confiantes, sorridentes, atraentes, inteligentes, desejadas. Sabem amar e são amadas. São visíveis e se fazem visíveis projetando sua visibilidade através de um projeto de corpo.

\title{
5.5. Corra, sujeito corpo perfeito, corra!
}

Amado por uns, odiado por outros, o filme alemão Corra Lola Corra (Lola Rennt, 1998) de Tom Twyker, é uma metáfora da velocidade. A obra trabalha com duas coisas cruciais ao 
homem na atualidade: tempo e dinheiro. Fiel ao título, a protagonista corre alucinadamente durante quase todo o tempo de projeção. Um filme que começa três vezes; e termina três vezes.

Assim como a personagem Lola, que precisa correr para salvar o namorado que está em apuros, o sujeito contemporâneo precisa correr para salvar a si mesmo. Correr para estudar, para obter um diploma, um companheiro magistral, uma carreira bem sucedida, um corpoperfeito. Correr para alcançar o sucesso. A forma sujeito-voraz descrito por Payer (2015), que tudo quer fazer, saber, ver, não pode se dar ao luxo de existir, funcionar v-a-g-a-r-o-s-a-m-e-nt- e. Nem quando está doente. O corpo adoecido não pode parar, já que não é produtivo. Uma campanha publicitária de um produto que promete aliviar os sintomas da gripe reforça que o pecado mortal que o sujeito contemporâneo não pode cometer na liturgia do mercado é parar em qualquer cirscunstância. Em um dos vídeos da campanha, uma atriz famosa (com seu corpoperfeito) proclama: “Coristina D tem três camadas: tira a dor, desentope e revigora e não me deixa parar por uma gripe. Coristina D: cuida de você!" ${ }^{179}$ Em outra peça publicitária, mais do que "simplesmente" correr o sujeito é incitado a "nunca parar de correr":

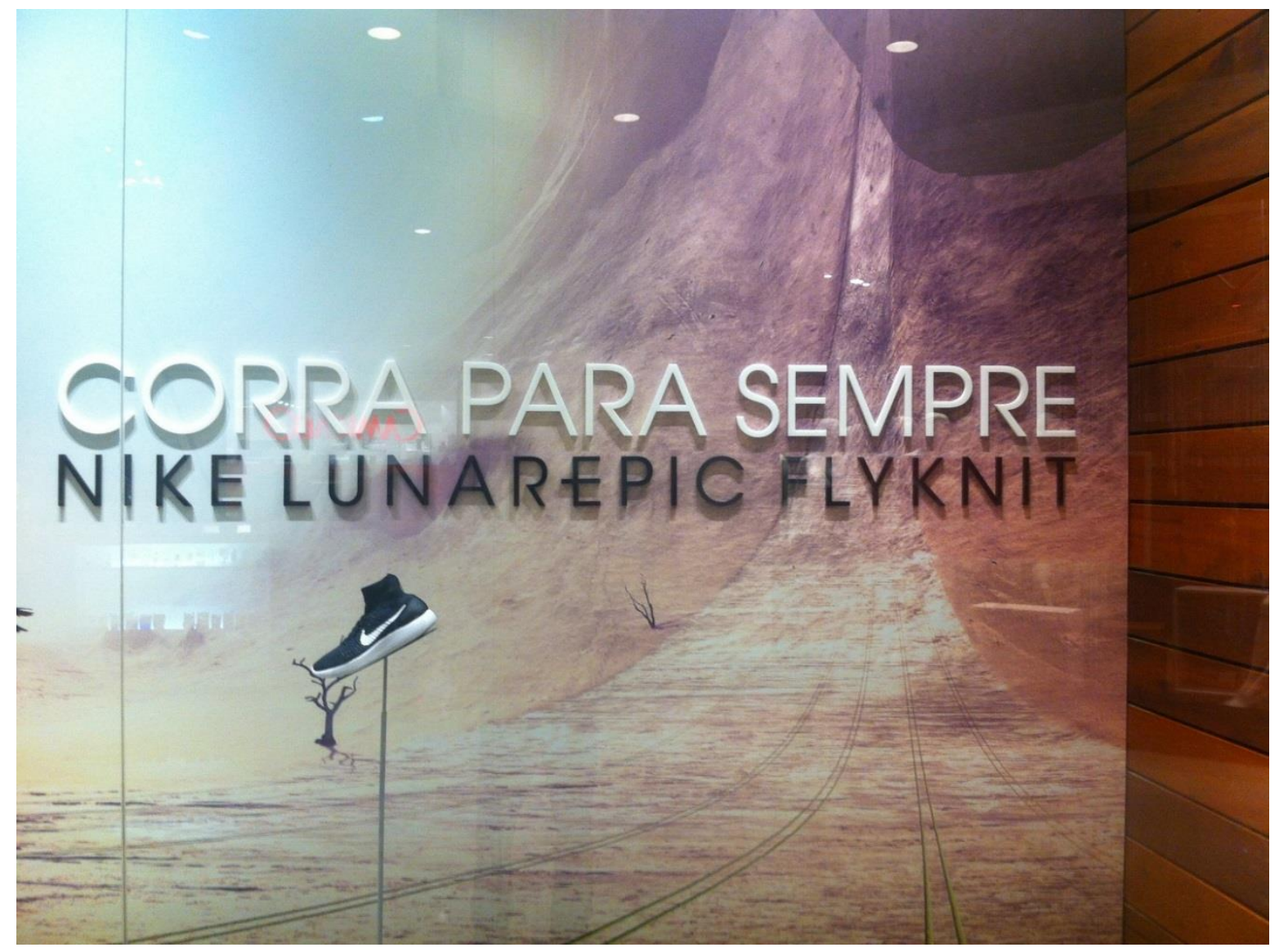

${ }^{179}$ Recuperado em 29 de junho de 2016, de https://www.youtube.com/watch?v=W51oBn9pq7k 
Figura 20. Vitrine de uma loja de artigos esportivos em um shopping da cidade de São Paulo

Se o texto do mercado faz circular efeitos de sentidos de novidades em alta velocidade, como o surgimento incessante de novas dietas, o ato de emagrecer também está submetido ao jugo deste mesmo mercado. Emagerecer de forma rápida é uma das práticas de assujeitamento do sujeito à ideologia das dietas:

\section{Recorte 41:}

Magra em 5 minutos. $\mathrm{O}$ treino funcional power que queima por $48 \mathrm{~h}^{180}$

Keep calm and enxugue $4 \mathrm{~kg}$ (ou mais) em 1 mês ${ }^{181}$

Perca até $3 \mathrm{~kg}$ em uma semana tomando sopa à noite ${ }^{182}$

- $8 \mathrm{~kg}$ este mês \& flacidez zero. A dieta que é sucesso entre as americanas ${ }^{183}$

14 receitas Dukan para afinar rápido ${ }^{184}$

Perca até $6 \mathrm{~kg}$ em um mês seguindo o cardápio das cores do verão. É a NãoDieta! ${ }^{185}$

Dieta Viking: - $2 \mathrm{~kg}$ por semana! $!^{186}$

- $5 \mathrm{~kg}$ em 21 dias com direito pé na jaca ${ }^{187}$

- $10 \mathrm{~kg}$ com o desafio de verão. Circuito acelerado, resultados rápidos ${ }^{188}$

Vata, Kapha ou Pitta? Descubra o seu perfil e perca até 6 kg em um mês com a dieta certa ${ }^{189}$

Cardápio termofuncional seca $6 \mathrm{~kg}$ e afina $4 \mathrm{~cm}$ de barriga em um mês ${ }^{190}$

Dieta Clean. - $5 \mathrm{~kg}$ em 21 dias. Agora é a hora! ${ }^{191}$

- $3 \mathrm{~kg}$ por semana! Com a dieta da sopa detox ${ }^{192}$

Corra atrás da saúde. Coloque os hormônios de volta na linha de um jeito natural ${ }^{193}$

Os enunciados acima fazem circular efeitos de sentidos de velocidade, rapidez. O discurso das dietas traz inúmeras esperanças: “- $5 \mathrm{~kg}$ em 21 dias com direito pé na jaca” ou “8 kg este mês \& flacidez zero"? A promessa de perder "3 kg por semana" tomando apenas sopa

\footnotetext{
${ }^{180}$ Chama de capa da revista Boa Forma (edição n. 345).

${ }^{181}$ Chama de capa da revista Boa Forma (edição n. 347).

182 Chama de capa da revista Boa Forma (edição n. 344).

${ }^{183}$ Chama de capa da revista Shape (edição n. 66).

${ }^{184}$ Chama de capa da revista Shape (edição n. 66).

${ }^{185}$ Chama de capa da revista Corpo a Corpo (edição n. 324).

${ }^{186}$ Chama de capa da revista Shape (edição n. 68).

${ }^{187}$ Chama de capa da revista Shape (edição n. 67).

${ }^{188}$ Chama de capa da revista Boa Forma (edição n. 348).

${ }^{189}$ Chama de capa da revista Corpo a Corpo (edição n. 321).

${ }^{190}$ Chama de capa da revista Corpo a Corpo (edição n. 314).

${ }^{191}$ Chama de capa da revista Boa Forma (edição n. 340).

192 Chama de capa da revista Shape (edição n. 69).

193 Matéria da revista Women's Health (edição n. 86, p. 29)
} 
à noite é mais eficiente que perder apenas "6 kg em um mês seguindo o cardápio das cores do verão"? As dádivas multiplicam-se com números (subtraindo o peso e o tempo de emagrecimento); com adjetivos (circuito acelerado, resultados rápidos; 14 receitas Dukan para afinar rápido). Esse efeito da velocidade vai na direção oposta ao processo de emagrecimento planejado, programado e executado com cuidado e respeitando os limites de cada organismo, em um compromisso, sinaliza Foxcroft (2013), para toda uma vida.

Uma única reportagem mostra como a manipulação simbólica do conjunto imagem/texto provoca um deslizamento dos efeitos de sentidos. A chamada do texto "Corra atrás da saúde" está ao lado de uma mulher vestida com roupas de academia e praticando corrida, ao que tudo indica, ao ar livre. "Correr atrás da saúde” poderia significar um conjunto de atitudes como consultar médicos e fazer exames regularmente de acordo com o que é prescrito em cada período da vida, manter uma alimentação saudável, evitar vícios, etc. No entanto correr (no sentido de andar em velocidade) é a maneira como o sujeito é convocado a manter-se saudável. O texto continua com imagens de uma mulher praticando exercícios (levantamento de peso e corrida) e mostra (sempre com o uso do imperativo) o que uma mulher deve fazer para alterar o seu estilo de vida (a revista já supõe que o sujeito-leitor é sedentário):

\section{Recorte 42:}

Perca peso de maneira equilibrada

Ouça o que seu corpo diz

Alimente-se de maneira mais esperta

Cuide do sono

Mexa este corpo, garota!

Relaxe todos os dias

Enquanto o discurso da boa forma interpela o sujeito intimando-o a ser mais ágil e rápido na busca do corpo-perfeito, o corpo da realidade testa seus limites deparando-se com sua fragilidade. $\mathrm{O}$ corpo adoece, sente dor, precisa de descanso. O corpo não é máquina, apesar dos dizeres sobre os corpos equipará-los à eficácia dos computadores; eis uma das ilusões da contemporaneidade que julgamos ser necessário desnaturalizar, observa Gallo e Romão (2011).

O re(fabricar) a si mesmo é um imperativo da contemporaneidade. Re(fabricar) o corpo para que ele seja mais magro, mais rápido, mais eficiente e produtivo. Parece que nossa época tenta impor ao corpo a eficiência das máquinas: não há espaço para o descansar, o dormir, o relaxar, o contemplar. Certa vez ouvi de um amigo que um professor de uma Faculdade de Administração disse aos seus alunos: “dormir é para os fracos”. Os recortes acima nos dão 
pistas dos dizeres sobre o corpo: depois de perder peso, alimentar-se corretamente, cuidar do sono e mexer o corpo, ainda deveria sobrar espaço para "relaxar todos os dias". Fácil?

Nossa reflexão sustenta-se, conforme já relatamos, em uma conjuntura atual: a ideologia das dietas e boa forma está atrelada ao mercado, que por sua vez interpela os sujeitos através da mídia, convocando-os a um estágio de excelência que se materializa em um eminente design corporal (corpo-projeto.). O sujeito é interpelado a re(fabricar)-se a todo momento. A forma sujeito grávida-perfeita é um exemplo do flagrante da estreita relação entre a produção dos enunciados e a configuração da sociedade e de seus sujeitos (Payer, 2015). O imperativo "sucesso" perpassa as formações ideológicas e seus discursos:

\section{Recorte 43 ${ }^{194}$ :}

Supere seus limites. Estabeleça um objetivo e não desista até alcança-lo. A sensação de chegar lá é boa demais! A coleção de maio da BOA FORMA Marisa vai inspirá-la a ir mais longe. Veja onde encontrar o top (39,99 reais), o corsário (59,99 reais) e outras peças no marisa.com.br/especial/boaforma. ${ }^{195}$

Mantenha a motivação. Precisando de um incentivo extra para não faltar ao treino? Nós damos três [...]

3 - A coleção de junho da BOA FORMA Marisa. Em tons de rosa e preto e com elastano reforçado, as peças vão ser uma ótima companhia. Veja onde comprar o topo $(49,99)$ e o short-saia $(59,99)$ no marisa.com.br/especial/boaforma. ${ }^{196}$

A vida contemporânea parece não oferecer barreiras para a autorrealização, e os imperativos de gozo tornam-se cada vez mais exigentes (Peres, 2001), com a crescente "valorização do desempenho" como algo intrínseco à nossa sociedade, seja no trabalho, no sexo, no esporte. E nas exigências com o corpo, que assumiram proporções surpreendentes:

O corpo é manipulado, transformado, exposto, atacado. Pensemos na body art, tatuagens e piercings, na anorexia e na bulimia, nas cirurgias para embelezamento e rejuvenescimento e, ainda, no poder da medicina, sua farmacologia, para atuar na vida sexual, no sono, na alegria, na forme, no emagrecimento (Peres, 2001, p.134 - grifos nossos).

\footnotetext{
${ }^{194}$ Esses recortes poderiam fazer parte da reflexão que fizemos no Capítulo 2 (item 2.6 - A consumidora consumida (corpo-projeto): "sei que eu vendo"). Aliás, vários recortes poderiam ter sido distribuídos em diferentes sessões deste trabalho, já que permitem compreender os diversos enunciados de um mesmo processo discursivo.

195 Matéria/anúncio da revista Boa Forma (edição n. 343, p. 122).

${ }^{196}$ Matéria/anúncio da revista Boa Forma (edição n. 344, p. 114).
} 
Os efeitos de sentidos da ideologia do mercado, de impor ao sujeito a meta de ser bemsucedido, também faz vigorar sentidos de determinação. A palavra de ordem é "desempenho". Como vimos no recorte 43, o discurso da boa forma convoca o sujeito a "superar seus limites", "estabelecer objetivos" e "manter a motivação" para "ir mais longe", de preferência consumindo os produtos elencados. Peres (2011) traça um paralelo entre essa "valorização do desempenho", esse "desespero de competitividade" com a explosão das corridas e maratonas. A corrida também é frequentemente tema das notícias sobre dietas:

\section{Recorte 44:}

Quer começar a correr ou deseja melhorar o desempenho? ${ }^{197}$

Perca o medo de aumentar a distância e, em dois meses, cruze a linha de chegada da São Silvestre com muuuito orgulho! ${ }^{198}$

Apaixone-se pela corrida. A gente ensina ${ }^{199}$

Corrida + caminhada. Planos para reduzir medidas de iniciantes, intermediárias e avançadas ${ }^{200}$

Os exercícios que quem corre deveria fazer ${ }^{201}$

Ler a entrevista com a Letícia me deu um novo ânimo para voltar a correr e conquistar as curvas que sempre quis. Pura inspiração! $!^{202}$

Não é por acaso que se corre tanto hoje - afirma Peres (2011) - quando as maratonas viraram moda. "O corredor vive uma luta constante para ultrapassar seus próprios limites, uma obsessão de velocidade. Entramos em uma verdadeira 'era da maratona', na qual o tempo urge, e todos querem disputar um lugar" (Peres, 2011, p.134). Corra mais rápido. Perca mais quilos. Emagreça em menos tempo. Faça. Você pode. "Mire o topo" 203 convoca uma das matérias sobre um aparelho que imita escadas e ajuda a emagrecer. Outro aspecto repousa novamente na interpelação do sujeito pelas imagens midiáticas e seus discursos. As imagens não descansam, não ficam ofegantes, não sentem dor, apenas correm e correm e correm. Certa vez, estava em uma academia e sentia dor ao realizar um determinado exercício (para mim estava claro que tanto a carga quanto a repetição eram superiores ao que eu conseguia de fato suportar). Ao executá-lo, meu semblante não escondia o desconforto que estava sentindo. O treinador

\footnotetext{
${ }^{197}$ Chama de capa da revista Corpo a Corpo (edição n. 317).

198 Matéria da revista Corpo a Corpo (edição n. 319, p. 88).

199 Chama de capa da revista Boa Forma (edição n. 340).

${ }^{200}$ Chama de capa da revista Corpo a Corpo (edição n. 306).

${ }^{201}$ Chama de capa da revista Boa Forma (edição n. 343.

${ }^{202}$ Comentários dos leitores publicados na revista Corpo a Corpo (edição n. 315).

${ }^{203}$ Chama de capa da revista Boa Forma (edição n. 350, p.38). A matéria ainda evoca efeitos de sentidos da ideologia do novo e da novidade: "Nova sensação entre as celebridades, o aparelho que imita escadas é infalível para quem quer um corpo top".
} 
responsável naquele momento foi enfático: "Por que você está fazendo careta? Se sorrir fica mais fácil". As imagens dos corpo-projeto das revistas e sites estão sempre sorrindo mesmo quando estão se exercitando. Ou trazem um ar de sedução decorrente da exposição de seus contornos primorosos expostos em minúsculos trajes.

Como vimos até agora, as formações ideológicas e discursivas do corpo-projeto e das novas dietas fazem circular efeitos de sentidos que impulsionam e incentivam o sujeito à sua autorrealização pessoal-corporal. Os discursos sobre o corpo-gordo são apagados, silenciados, ou emanam efeitos de ironia e ridicularização. Não há espaços para outros enunciados: "De 35 para 62! Como consegui engordar $27 \mathrm{kgs}$ em 3 anos"204. O envelhecimento não encontra intervalo; o processo de inverteramento, quando ocorre, sucumbe aos critérios da ideologia do corpo-projeto. Mas o corpo teima em ser corpo.

\begin{tabular}{llllllll}
\hline 204 & Recuperado & em & 14 & de & junho & de & 2015,
\end{tabular}




\section{UM BREVE INTERVALO}

\section{Irromper para aproximar: Corpus Alienum}

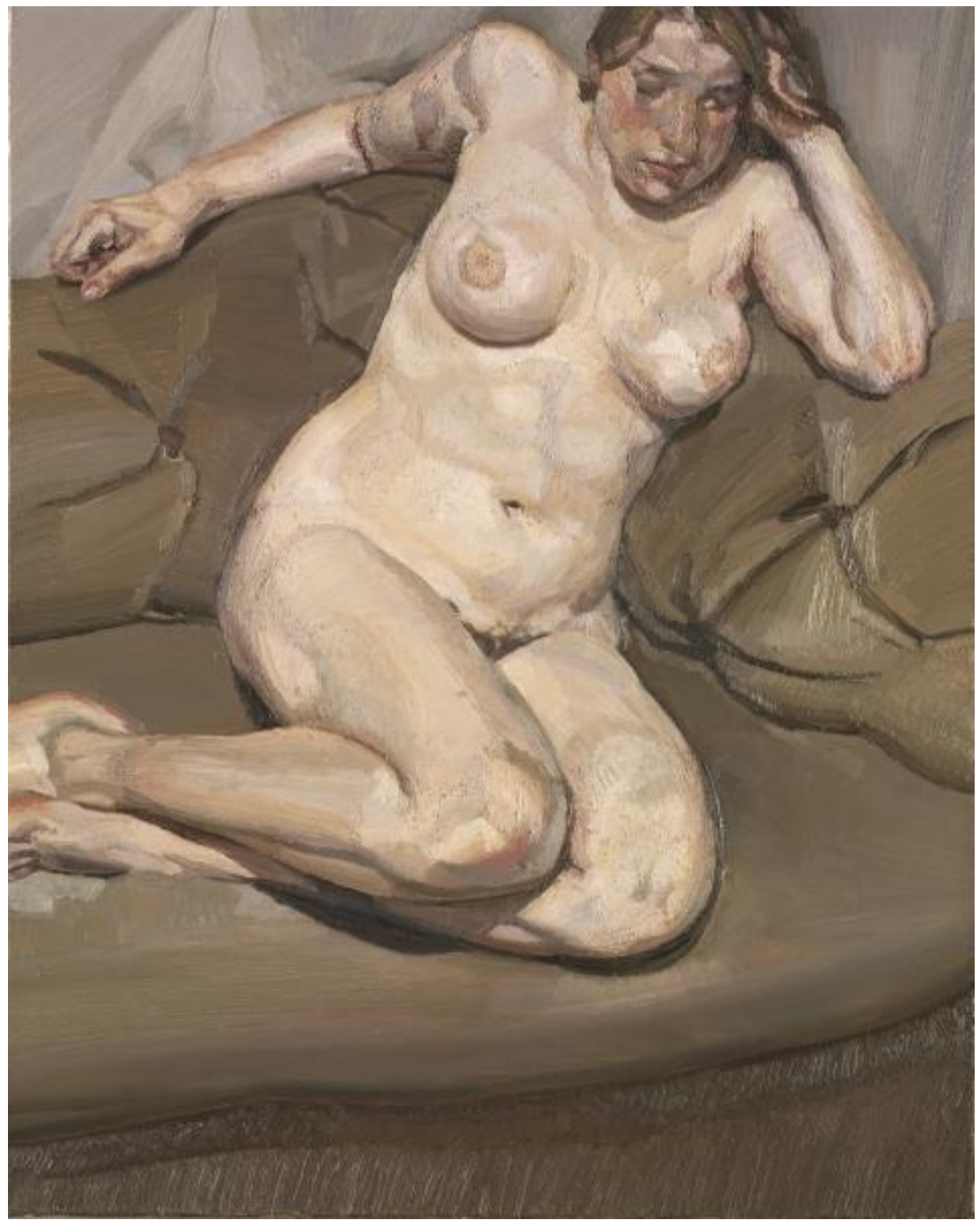

The Painter's Daughter Ib (Lucian Freud, 1977-1978)

A única realidade é aquela que se contém dentro de nós, e se os homens vivem tão irrealmente é porque aceitam como realidade as imagens exteriores e sufocam em si a voz do mundo inteiro.

Hermann Hesse

Extrair grande prazer de um mundo repleto de muitas espécies de beleza é uma alegria na vida à qual todas as mulheres fazem jus.

Clarissa Pinkola Estés 
A metáfora do caminho, que adotamos para esta tese, teve como intenção empreender uma investigação sobre um fenômeno que julgamos particularmente atual. Um itinerário pode ser entendido como uma distância ou espaço percorrido para chegar a determinado lugar. Se qualquer caminho leva a toda parte, era preciso escolher esse ou aquele rumo. Traçado o mapa, deveríamos, então, percorrê-lo. Obviamente, a trajetória foi revista e refeita sempre que julgamos interessante ou necessário. Percorrer remete a visitar em toda a extensão ou em todos os sentidos. Impossível. Confesso que tentamos. Apesar de termos a noção da impraticabilidade da totalidade: "o discurso é sempre incompleto assim como são incompletos os sujeitos e os sentidos", (Orlandi, 2005, p. 92).

O importante é questionar: será que chegamos a algum lugar? Acreditamos que sim. Para sustentarmos o percurso investigativo que se configurou esta tese e que agora parece chegar ao fim, apontamos nossas reflexões para algumas direções que efetivamente nos incomodavam, na tentativa de descortinar outros efeitos e outros sentidos de um discurso que continuará a nos incomodar. Nossa chegada não resulta em conclusão ou finalização. Portanto, a este último momento daremos o nome de intervalo, estada. Para nós, chegar não significa interromper, mas irromper. Aproximar-se. Alcançamos o fim deste trajeto, um recorte no espaço e no tempo; tocamos em alguma coisa. Mas o movimento de ir e vir continua. E continuará. Sempre. Por que os fenômenos nunca cessam. Por analogia, se os discursos midiáticos das dietas fossem um deserto, este trabalho seria uma poeira de ideias.

De certo modo, se designamos esta etapa do nosso percurso investigativo de intervalo, ele já vem acontecendo a cada capítulo ou reflexão. Para relatarmos, então, este momento específico, ou o que priorizamos nele, propomos um regressar. Não de maneira linear (do fim para o início, apenas), mas de forma condensada e compreensível. Do ponto de vista discursivo, diz Orlandi (2005, p. 93), "não há um fim punctual como não há um começo absoluto". Recordemos o modo como projetamos nosso roteiro: tanto as análises quanto os conceitos não seriam abordados hermeticamente, mas em um permanente entrelaçamento entre teoria e corpus da pesquisa. Nosso objeto de pesquisa é dinâmico e não linear. Seria praticamente impossível compreender aspectos tão complexos em um capítulo destinado exclusivamente às análises. A ideologia do novo e a novidade, por exemplo, desponta em múltiplos recortes e perpassam inúmeras análises e reflexões. Metodologicamente, encontra-se no capítulo 4. Mas suas bordas transbordaram para todo o trabalho. Há também uma questão da ordem do fazer científico: a ciência e a linguagem não dão conta da complexidade da vida. Mas ajudam a apontar cenários e iluminar os rastros e vestígios dos caminhos. 
Assim como fez Botton (2015) ao examinar o noticiário, que considera de longe o mais influente meio de educar as populações, o que procuramos no decorrer desta tese foi uma tentativa de fazer o hábito de consumir e se deixar consumir pelo discurso das novas dietas e boa forma, tão familiar e onipresente, parecer muito mais estranho e perigoso do que o consideramos. Embarcar em uma dieta, explica Foxcroft (2013), não é um empreendimento simples, pois "não se trata apenas de alterar a forma corporal física: trata-se de alterar a forma que a pessoa ocupa em uma sociedade e, ao fazê-lo, mudar o que o seu corpo diz ao resto do mundo" (pp. 51-52).

Não pretendemos, com este trabalho, fazer apologia à obesidade e ao sedentarismo. Não somos contra a prática de atividades físicas, alimentação adequada e emagrecimento de modo equilibrado e saudável. Esse percurso de pesquisa teve como objetivo investigar um discurso que segue produzindo efeitos muitas vezes perversos, ao confrontar a mulher contemporânea com um corpo dotado de atributos inalcançáveis, formado por um conjunto de características (luz, textura, silhueta) que não são identificados na vida real. Ademais, não refutamos a novidade e a inovação. "Nem tudo o que é novo é garantia de qualidade, assim como nem tudo o que é antigo prescinde de valor" (Payer, 2005, p. 24). O que tentamos perscrutar é a renovação incessante dos hábitos alimentares promovida pelo discurso das dietas. Como dissemos no decorrer do texto, não há consenso e muito menos bom senso das publicações em orientar a mulher a alimentar-se adequadamente, perdendo a grande oportunidade de serem responsáveis e protagonistas na melhoria da saúde da população. As publicações deveriam repensar a abordagem sobre dietas e boa forma, atentando para as condições de existência da mulher na atualidade, de forma responsável. E não apenas criando enunciados que parecem preencher todos os espaços, saturando "os sujeitos com sentidos muitas vezes absolutamente estranhos a uma dada realidade" (Payer, 2005, p. 25).

O discurso sobre as novas dietas e suas supostas novidades promovem um arrebatamento da mulher contemporânea, proveniente da sua força de interpelação. Enquanto fenômeno comerciável, faz vender uma gama (quase inesgotável) de produtos, serviços, procedimentos, alimentos e alimentação, exercícios, etc. Esse discurso (res)significa o corpo. O conceito de corpo que aqui mobilizamos não é somente o de um organismo empírico, mas um corpo simbólico. Ao relacionarmos sujeito/corpo/linguagem/sociedade, tentamos compreender como o corpo, pensando a materialidade do sujeito, sua historicidade, é significado na/pela ambiência midiática das dietas e seus discursos. Nosso foco é o sujeitomulher do/no discurso midiático das dietas. O corpo é visto na atualidade como um produto. Um produto de si, que faz ressoar sentidos (de si e para os outros); sentidos sobre um "estar no 
mundo" com seu corpo. Um habitar físico e simbólico, imaginário. O corpo, para a AD, significa. E é ressignificado.

Para a mídia, especificamente no texto midiático das dietas e boa forma, o corpo autorizado a circular é um corpo perfeito. Um dos efeitos desse texto é o sentido de completude presente na imagem do corpo-imagem. A iconografia das dietas, homogênea e homogeneizante, através de um jogo de filiações históricas, exala sentidos sobre a beleza da mulher contemporânea. Em nosso corpus, notamos que essa beleza tem como premissa o estímulo ininterrupto de um corpo ideal. E para alcançar esse arquétipo, o sujeito-mulher é sucessivamente interpelado a consumir novos produtos, novas dietas, novos exercícios. Nesse jogo discursivo, sujeito e sentido constituem-se mutuamente. Portanto, corpo e sentido constituem-se simultaneamente. E nessa composição recíproca, notamos o funcionamento da ideologia autorizando o que pode e deve ser dito e compreendido sobre a aparência do corpo feminino na atualidade.

Os dizeres autorizados a circularem pela ideologia das dietas ressoam sentidos sobre os patamares de excelência do corpo feminino através do corpo-imagem. Se cada época, diz Foxcroft (2013), tem uma configuração de corpo para chamar de sua, nos nossos dias esse modelo é determinado sobremaneira pela mídia. Quer deixar o seu corpo assim? questiona um dos enunciados de nosso corpus. Se fosse possível realizar uma análise dimensional dos corpos que circulam nas publicações, o que os resultados revelariam? As medidas desses corpos seriam compatíveis com os formatos reais? A iconografia das dietas faz ressoar efeitos de sentidos ao repetir exaustivamente um padrão corporal, incitando e instigando a mulher a cobiçá-lo. A imagem assume, assim, papel crucial em nossa análise. Sustentamos, dessa forma, que a imagem é um dos meios mais eficazes de interpelação do sujeito-mulher na atualidade. Não qualquer imagem, mas o corpo-imagem. Defendemos, ainda, que a imagem (corpo-imagem) é o grande outro do corpo. Um outro que é capaz de influenciar a percepção corporal da mulher através de uma mimese imagética e social. Isso ocorre por um processo inerente ao indivíduo que, ao ser interpelado em sujeito pela ideologia, traz seu corpo por ela também interpelado (Orlandi, 2012a).

A imagem, enquanto outro do corpo, faz propagar efeitos de completude e potência que esbarram na incompletude do próprio corpo. O texto midiático das dietas e boa forma é trabalhado de modo a estrugir efeitos de sentidos de uma panaceia, com a entrega de poções mágicas capazes de extinguir a gordura, já que a mulher contemporânea deve se submeter ao design corporal vigente na atualidade. E o corpo atual deve ser magro. As sociedades atuais detestem a gordura e o corpo acima do peso tido como aceitável. As publicações podem até 
justificar a produção e circulação desse discurso como algo que pode ajudar a mulher a emagrecer, praticar atividades físicas e a praticar uma alimentação saudável. No entanto, conforme observamos ao analisar os recortes que compõem uma parcela significativa das publicações presentes em nosso corpus, esses enunciados expõem a mulher à novas dietas de forma incessante, sugerindo uma alimentação voltada apenas para o emagrecimento rápido, confrontando o seu verdadeiro corpo a um corpo-perfeito, maquinal, de uma beleza idealizada que não encontra ressonância em um organismo vivo. Na Formação Discursiva do universo das dietas, tanto os enunciados quanto à iconografia (materialidades significantes atuando em conjunto) que circulam na mídia ressoam sentidos intrínsecos à perda de peso subjacente aos padrões corporais atuais, o que se marca pelo uso numérico de quilos a serem perdidos em um determinado número de dias.

A ideologia do novo e da novidade no universo das dietas, atrelada à velocidade com que o discurso midiático circula na ambiência midiática, marca o processo de emagrecer como algo descomplicado e de resultados rápidos. E repetitivo. Após quatro anos olhando as imagens e os enunciados sobre dietas e boa forma, ir até uma banca de revistas ou visitar um site sobre o tema nos remete à canção do cantor e compositor Cazuza: "Eu vejo o futuro repetir o passado, eu vejo um museu de grandes novidades". As publicações sobre as novas dietas e boa forma são como "máquinas repetidoras do tempo" (Kamper, 2016, p. 85). O sujeito está sempre surfando nas ondas das novidades, em um processo econômico e social no qual mercadorias e compradores nascem do/no mesmo transcurso discursivo. Realizam-se conjuntamente. Forma histórica sujeito-capitalista (consumidor moderno).

As novas dietas esbarram na obsolescência do corpo, que é convocado a manter-se sempre jovem e sempre magro. Corpo novo, corpo renovado, corpo jovem. Não há, nas Formações Discursivas das dietas e boa forma, espaço para o velho, o envelhecimento e, muito menos, para a morte. Qualquer marca imposta pelo envelhecimento deve ser impelida. As marcas do tempo deixadas no corpo compõem o que Kamper (2016) batizou de um outro nome para a pele humana - escrita em cicatriz - "feridas curadas que, de tão encadeadas no tempo, podem ser lidas" (p. 88). Ao alterar o formato da pele e do corpo via programas de computador, as publicações promovem um apagamento da história do corpo. As celebridades que emprestam seus corpos a esse tipo de publicação e aceitam as alterações digitais têm, igualmente, suas histórias modificadas e recontadas discursivamente, seja na perfeição da pele, no contorno do corpo ou nos enunciados de superação e sucesso.

As informações sobre novas dietas também circulam em uma velocidade incompatível com o viver. A perda de peso deve ser rápida, eficaz e definitiva, o que marca um modo de 
inscrição do tempo, qual seja, o tempo acelerado e com consequências próximas. Instaurada pelas tecnologias de comunicação, a circulação do discurso também ocorre cada vez mais rápido, exigindo do sujeito uma adequação a esse modo de existir. A existência é marcada pela velocidade da instantaneidade, interatividade e urgência (Gallo e Romão, 2011). A mulher deve correr para se manter up to date, correr para emagrecer, correr para conhecer novas dietas, correr como prática física, correr para nunca mais parar de correr. Forma histórica sujeito-voraz.

O texto midiático das dietas e boa forma é produzido sob certas condições de produção, em uma rede de evidências no qual se constituem os sentidos e o sujeito-consumidor das dietas. Em um contexto mais amplo, a constituição dos dizeres sobre corpo e dietas se faz a partir de alguns aspectos. O corpo é resultado de uma construção sócio-histórica. Nossa época abomina a gordura e os corpos gordos (lipofobia). Vivemos sob o domínio ideológico do capitalismo. Em um contexto mais estrito, podemos abordar o texto midiático das dietas e boa forma (foco desta tese), que consideramos apenas um dos milhares de tentáculos do amplo texto da mídia (Payer, 2005), e a tecnologia.

Ainda em sentido mais restrito podemos pensar na linguagem publicitária do discurso das dietas, que estão subjacentes, por exemplo, aos enunciados milimetricamente construídos para fisgar o sujeito-leitor. Essa linguagem está igualmente por trás da denominação de muitas das dietas que circulam em nosso corpus, fazendo ecoar efeitos de sentidos que evidenciam uma certa dose de credibilidade (quando atrelada a um profissional) ou de poderes mágicos (quando atribuída a um ou mais alimentos) ao ato de emagrecer. Na linguagem publicitária, normalmente os verbos encontram-se no imperativo, para não deixar margem à dúvida. E os recursos linguísticos se repetem, em uma regularidade enunciativa. Os números empregados nesse discurso são uma prova dessa regularidade: uma nova dieta é comumente atrelada a um valor numérico. Pratique o novo regime e emagreça "tantos" quilos. Nas marcas linguísticas materializadas no dicionário para a palavra "dieta", não constam perda de peso ou diminuição da massa corporal. Em comum, tais sequências reiteram que os efeitos de sentidos das dietas têm como objetivo fazer desaparecer ou definhar os contornos corporais. O objetivo é subtrair, enxugar, eliminar, diminuir as medidas corporais.

Ao estabelecer padrões imagéticos, o discurso das dietas determina quais os critérios visuais as mulheres devem conquistar. O corpo-imagem faz circular efeitos de sentidos dominantes sobre o design do corpo. Ao pensarmos na relação entre corpo, sujeito e sentido, o corpo-imagem, enquanto materialidade significante presente nas formações ideológicas e discursivas sobre as dietas, interpela o sujeito e interfere na relação com o seu próprio corpo. 
Assim como a imagem do corpo-imagem não encontra ressonância na vida real, tampouco as práticas para emagrecer parecem ser viáveis ao sujeito comum. Os corpos podem parecer ou se espelharem nas imagens, elucida Kamper (2016), mas em hipótese alguma encontrarão plena realização enquanto tal. As novas dietas são discursivizadas como de fácil execução e alto desempenho. Os enunciados fazem circular efeitos de facilidade, velocidade e rapidez no processo de emagrecimento. Esse efeito de velocidade vai na contramão de uma metodologia para emagrecer que respeite as singularidades do sujeito, os limites do seu organismo e as suas condições de existência.

Além da linguagem tecnicamente elaborada, as condições de produção do texto midiático das dietas e boa forma englobam a ambiência midiática, composta pelo desenvolvimento de tecnologias de comunicação. O conceito de tecnologia mobilizamos nesta tese vai além dos dispositivos eletrônicos, concatenando tudo aquilo que potencializa o discurso e promove sua eficácia discursiva, como aspectos como globalização, economia, ciência, o refinamento da linguagem, a alteração técnica das imagens, enfim, tudo aquilo que dão vida à ambiência midiática. Esse ambiente demanda do sujeito novas competências comunicativas imprescindíveis para o seu "estar no mundo", existir e relacionar-se. Forma histórica sujeitoconectado. A ambiência midiática é impulsionada em grande parte pelas organizações de mídia. Essas instituições corporativas possuem fins lucrativos, e funcionam em uma mecânica que, segundo Botton (2015), é difícil de questionar. Isso foi um dos motivos que impulsionaram nossa pesquisa: indagar o funcionamento dessas publicações (impressas ou virtuais), seu modo de emitir sentidos sobre as dietas e o corpo feminino, sempre visando o lucro. Os enunciados sobre dieta e boa forma presentes em nosso corpus são simbolicamente disciplinados (Mariani, 2007), estabilizando os dizeres e os sentidos sobre certas condições de existência da mulher contemporânea, como os atuais critérios de beleza subjacentes ao desenho do corpo. O texto da mídia (a exemplo do discurso das dietas), não oferece a realidade, mas uma construção simbólica de representação da realidade (Gregolin, 2007).

Através dos vestígios discursivos do texto midiático das dietas e boa forma, podemos perceber que o sujeito-leitor-consumidor das publicações (impressas ou virtuais) sobre dietas e boa forma consome essas informações de maneira contumaz. A mulher, público alvo desse discurso, é incentivada, a cada enunciado, a conhecer e praticar novas dietas, com novos alimentos, exercícios ou diferentes métodos para emagrecer. A ser uma nova pessoa, portando um novo corpo: 


\section{Recorte 45:}

FERNANDA VASCONCELLOS. Linda, loira e mais magra do que nunca com detox e corrida leve ${ }^{205}$

A NOVA FERNANDA VASCONCELLOS. Não é impressão: a atriz de olhos e sorriso arrebatadores, que há dez anos despontou como protagonista de Malhação, cresceu, apareceu e emagreceu ${ }^{206}$

Quando dissemos que um corpo já vem significado, argumenta Orlandi (2012b, p. 25), pensamos "ideologicamente, ou seja, na imagem que fazemos de um corpo ocidental ou oriental, ou como pobre ou rico, como homem, mulher ou homossexual etc. Sentidos já dados. Estabelecidos ou estabilizados". A publicação do recorte acima nos permite visualizar, de uma única vez, vários vestígios da Formação Discursiva das novas dietas e corpo-projeto, em especial a forma sujeito corpo-(re)fabricado, (re)feito e (re)elaborado de acordo com os cânones da ideologia das dietas e do emagrecimento. Um mês antes à publicação, um site de celebridades destacava: "Fernanda Vasconcellos passa de manequim 38 para o 34 em um mês" ${ }^{207}$. Para o discurso midiático das dietas, uma mulher mais magra do que nunca é uma NOVA mulher. O texto da publicação acima reforça ainda a nova dieta da atriz, que "prioriza proteínas magras e gorduras boas e reduz o consumo de carboidratos”. Além de não poder envelhecer, a mulher atual não pode engordar, sendo obrigado a (re)fazer de práticas para emagrecer. Como reforça o enunciado, a atriz cresceu, apareceu e emagreceu. Consequentemente, enquanto imagem midiática a celebridade é obrigada a emagrecer para aparecer, devotando-se a um assíduo (re)modelar-se. A nova atriz exibe ainda "Cabelo, corpo e rosto bem tratados [...] Face sempre jovem [...] Tudo no lugar"208. Essa publicação reuniu muitos elementos que circulam no texto midiático das dietas e boa forma. Além dos que já relatamos anteriormente, são elencados a juventude eterna, o corpo-projeto com tudo no lugar, a magreza extrema, o sucesso atrelado ao ato de emagrecer.

No texto referente ao recorte anterior, percebemos ainda um esforço em transmitir efeitos de naturalização da perda de peso. A diagramação realça uma declaração da celebridade: "Muita gente acha que emagreci fazendo dietas e cirurgias malucas, mas foi consequência de um processo natural" ${ }^{\text {209 }}$. Os procedimentos empregados pelas celebridades para esculpirem o

\footnotetext{
${ }^{205}$ Chamada de capa da revista Corpo a Corpo (edição n. 333)

206 Matéria da revista Corpo a Corpo (edição n. 333, p. 16).

207 Recuperado em 8 de janeiro de 2017, de http://ego.globo.com/famosos/noticia/2016/08/fernandavasconcellos-passa-de-manequim-38-para-o-34-em-um-mes.html

208 Matéria da revista Corpo a Corpo (edição n. 333, p. 22).

209 Matéria da revista Corpo a Corpo (edição n. 333, p. 21).
} 
próprio corpo poderiam ser descritos de diversas formas, menos como algo natural. Como reiteramos em nosso trabalho, há uma diferença gritante entre as condições de existência da mulher comum e das celebridades, que dispõem de recursos financeiros e toda uma estrutura para aperfeiçoar a imagem dos seus corpos. As imagens que ilustram a reportagem também configuram um notável exemplar do corpo-projeto. Elas reiteram o corpo extremamente magro da celebridade. $\mathrm{O}$ rosto, as mãos e as pernas são enxutos. Em uma página inteira, a atriz aparece vestindo um short minúsculo e um top em quatro imagens praticamente idênticas. A pose é repetida, há uma leve mudança de posição do rosto, apontando ligeiramente para cima ou para o lado. Ela sorri, e muito. Essa repetição iconográfica, além de reforçar os sentidos do corpoprojeto da atriz, emana efeitos de alegria, bem-estar e felicidade. Os efeitos resultantes do emagrecimento apontam para uma mulher feliz e plenamente realizada. Ainda em relação às imagens, a textura da pele é de um brilho desproporcional. Quantas mulheres com 31 anos de idade (a atriz estava prestes a completar 32 anos quando estampou a capa da revista) ostentam um manequim 34? Esse é um exemplo do que denominamos corpo-(re)fabricado, ou seja, do permanente esforço das celebridades em remodelar o contorno corporal para continuar aparecendo na mídia. Emagreço, logo EXISTO! Podemos auferir que as condições de existência do sujeito comum, sem prestígio ou notoriedade decorrentes da fama, também impõem à mulher atual uma frequente (re)fabricação de si mesma para fazer parte da exposição superabundante da era midiática em que vivemos, especialmente com o advento das redes sociais.

As Formações Discursivas das dietas estão ancoradas na velocidade e repetição, materializando esse discurso em regularidades enunciativas, que estabilizam certos dizeres em detrimento de tantos outros. Dizeres sobre o formato do corpo, a velocidade com que os quilos devem ser perdidos, as facilidades para alcançar um projeto idealizado de corpo. A superficialidade significante do texto midiático das dietas e boa forma, atrelada à repetição e à velocidade com que os discursos circulam na mídia, ecoam sentidos que promovem uma hipermegavalorização do corpo como "FORMA": não importam as aparentes/ilusórias transFORMAções, no mundo da iconização absoluta e esterilizadora das dietas e das imagens, tudo se reduz à "FORMA", sem alma, sem inteligência. O poeta concretista José Lino Grünewald, em um poema de 1959, nos faz pensar sobre a repetição da FORMA: 


\section{FORMA \\ REFORMA \\ DISFORMA \\ TRANSFORMA \\ CONFORMA \\ INFORMA \\ FORMA}

Em nosso trajeto, retornamos agora ao início. A FORMAtação da FORMA corporal, assim como todas as reflexões aqui empreendidas, devem ser pensadas subjacentes aos efeitos ideológicos do corpo-projeto. O corpo-projeto é o conceito que sustenta o corpo-imagem. É um padrão de corpo gerado artificialmente por programas de computador e transformado em imagens idealizadas de uma perfeição inalcançável. É um paradigma de um corpo supramundano, superior ao que é humano, divino, sublime. Conforme observamos neste trabalho, a imagem do corpo-projeto remete a um outro ser, hiperfísico, que parece não ser deste planeta, um corpo mais evoluído, revestido por um material que em nada se parece com a epiderme humana, ostentando contornos que não condizem com os organismos que habitam a Terra. A beleza midiática do corpo-projeto, que sustenta imaginariamente a Formação Discursiva do universo das dietas e seus efeitos de sentido circulam na mídia e constituem um discurso que não dá margem a outros tipos de corpos. Ao promover discursivamente a homogeneização dos sentidos sobre a beleza corporal, a mídia sucumbe à mulher contemporânea a carregar os escombros de si mesmas. "Defender apenas um tipo de beleza é de certo modo não observar a natureza”, argumenta Estés (2014, p. 151) ao defender que não pode haver apenas um formato de seio, de cintura, de pele. O corpo da mulher contemporânea, enquanto sujeito interpelado pela ideologia, é um corpo ligado ao corpo social, “e também isto não lhe é transparente, porque as instituições com seus discursos silenciam isto, tratando o social individualizado" (Orlandi, 2012b, p. 25). As instituições, no caso deste trabalho, são as publicações que fazem circular o texto midiático das dietas e boa forma.

Com o corpo-projeto, esse discurso "abre mão de deixar claro que não se limita a informar sobre o mundo, pelo contrário: empenha-se o tempo inteiro em modelar um novo planeta em nossa mente, um que esteja de acordo com suas prioridades muitas vezes bem específicas" (Botton, 2015, p. 11). No entanto, devemos nos ater para que os enunciados do mercado globalizado proliferados pela mídia não preencham todos os espaços, nem saturem os 
sujeitos com sentidos muitas vezes absolutamente estranhos a uma dada realidade (Payer, 2005).

Ao adjetivar o corpo magro e o ato de emagrecer, a Formação Discursiva das novas dietas atribui e faz ressoar sentidos benéficos ao corpo magro e à magreza. Por outro lado, faz ecoar sentidos humilhantes e vexatórios à gordura e ao corpo gordo. A maioria das novas dietas tem como premissa oferecer um manual, um plano para a mulher emagrecer muito e velozmente. A gordura corporal é discursivizada como um inimigo a ser vencido. Os discursos sobre o aspecto gordo são silenciados ou emanam efeitos de ironia e ridicularização. Um exemplo é publicação acima. O desenho uma mulher que exibe os contornos e texturas do corpo-projeto é enaltecido como um corpo harmônico, com tudo no lugar. Por oposição, o corpo acima do peso é desqualificado, pois suas curvas estão for a do lugar. Discursivamente, não somente a silhueta do sujeito-gordo está fora do lugar, desconjuntada, mas suas condições de existência encontram-se igualmente fora de lugar. O sujeito-obeso parece não existir: o seu estar no mundo é propelido pelas circunstâncias sócio históricas da sociedade-midiatizada. No entanto, Estés (2014) defende que:

Embora sejam verdadeiras e trágicas as perturbações da alimentação compulsiva e destrutiva que deformam as dimensões do corpo, elas não são a norma na maioria das mulheres. É mais provável que as mulheres que são grandes ou pequenas, largas ou estreitas, altas ou baixas, sejam assim simplesmente por terem herdado a configuração corporal dos seus parentes; se não dos parentes imediatos, então dos parentes de uma geração ou duas no passado" (p. 233).

O corpo-projeto é um desígnio inatingível para a maioria dos sujeitos, e daí reside sua força imagética e ideológica: se eu não consigo obtê-lo, mais esforço devo fazer para alcançar o sucesso almejado; devo emagrecer muito e rapidamente. É um objeto de admiração que está constantemente vociferando: "você pode e deve ser como eu". O corpo-projeto não aceita fracasso nem fracassados. Não tolera dúvidas, incertezas, temores, angústias, dificuldades, percalços ou as complexidades da vida e do corpo. Abomina, enfim, a dificuldade do "ser" (a existência real e absoluta), exaltando a magia do "aparentar" (o exibir da aparência). Se a maioria dos sujeitos não dispõe de tempo e recursos financeiros para alcançar o sonho do corpoprojeto (ou tem ambos e mesmo assim não consegue alcançá-lo), o sujeito "tem de elaborar o luto de suas não realizações, dos sonhos não atingidos" (Peres, 2011, p. 133). Se tanto é permitido - argumenta Peres (2011) - só a insuficiência e a incapacidade podem justificar não atingir patamares de excelência. 
A determinação na busca do corpo-projeto está atrelada ao exibir, aparentar, ser visto (seja na vida real ou virtual). O corpo-perfeito deve ser mostrado. Mas a busca da perfeição se choca com o corpo-vivo e suas limitações. O corpo real não é definitivo. Ele muda de formato nas várias fases da vida. Ele sente alegria e tristeza. Coragem e medo. Dor. Como o outro do corpo, a imagem do corpo-projeto alcançou a felicidade plena, interrompendo os processos naturais que acometem os organismos pulsantes. Ao ser fixado na imagem, realça Kamper, o corpo é "decretado como presente impossível" (216, p. 64). O corpo todo poderoso sem as marcas do tempo, argumenta Dias (2012, p. 43), é "um corpo cada vez mais enquadrado, regulado, autovigiado". A imagem não pulsa! O corpo, pulsa!

$\mathrm{O}$ avesso do corpo-projeto é a forma sujeito corpo-abjeto. Uma estrutura física real, um organismo vivo, cuja textura e cor e viço da pele são transformados pelo viver, cujo contorno é metamorfoseado com o passar do tempo. Os sentidos do discurso midiático das dietas e boa forma, ao enaltecer o corpo-projeto, menospreza o corpo-abjeto. O corpo-abjeto simplesmente é, enquanto o corpo-projeto está calcado em um devir, em um deve ser. As mulheres são criticadas e menosprezadas pelos sentidos das dietas por serem muito isso ou muito aquilo quando, de fato, deveriam ser valorizadas pelo que elas realmente são. A ideologia do mercado das dietas faz circular sentidos de um corpo-projeto que contrastam com a obsolescência do corpo da realidade, tomando-o como um objeto frágil e obsoleto pela gordura que carrega (dobras e vincos), pelo processo de envelhecimento e pelas doenças que o castigam. A mulher contemporânea é convocada a viver na perene encruzilhada entre a excelência imposta pelas ferramentas midiáticas e a imperfeição da realidade. O que pretendemos com este trabalho de pesquisa é provocar um estranhamento aos dizeres e sentidos estabelecidos e estabilizados, pelo texto midiático das dietas e boa forma, sobre o formato do corpo da mulher na atualidade. Entendemos, assim, que o corpo decorrente da prática discursiva das dietas é um corpo estranho, estrangeiro, alheio à realidade. Corpus alienum. Esperamos que após a leitura deste trabalho, além de um estranhamento proposto por um processo de desvendamento do discurso das novas dietas, o leitor possa desmistificar, desvelar, desenredar os sentidos de beleza atribuídos midiaticamente ao corpo feminino na atualidade. Corpus des-alienum. 


\section{REFERÊNCIAS}

Angélica, Banhara. (2005). Grávida em boa forma: Seu guia de exercícios e dieta para antes e depois do parto. São Paulo: Marco Zero.

Azevedo, Aline Fernandes. (2013). Cartografias do corpo: Metáforas contemporâneas da sutura e da cicatriz. Tese (doutorado) - Universidade Estadual de Campinas, Instituto de Estudos da Linguagem. Campinas.

Baitello Jr., Norval. (2012). O pensamento sentado: Sobre glúteos, cadeiras e imagens. São Leopoldo: Editora Unisinos.

Baitello Jr., Norval. (2010). A serpente, a maçã e o holograma: Ensaios de comunicação e cultura. São Paulo: Paulus.

Baitello Jr., Norval. (2005). A era da Iconofagia: Ensaios de comunicação e cultura. São Paulo: Hacker Editores.

Baitello Jr., Norval. (1997). O animal que parou os relógios: Ensaios sobre comunicação, cultura e mídia. São Paulo: Annablume.

Barber, Benjamin. (2009). Consumido: como o mercado corrompe crianças, infantiliza adultos e engole cidadãos. Trad. Bruno Casoti. Rio de Janeiro: Record.

Barber, Benjamin. (2003). Cultura McWorld. In Dênis de Moraes (org.). Por uma outra comunicação: Mídia, mundialização cultural e poder. (pp. 105-137). Rio de Janeiro: Record.

Bastos, Gustavo Grandini; Garcia, Dantielle Assumpção \& Sousa, Lucília Maria Abrahão e Sousa. (2014). O discurso na rede eletrônica e o Google: o movimento LGBT em destaque. Revista RUA, Campinas, v. 20, n. 2, p. 33-50.

Laus, Maria Fernanda (et al.). (2013). A influência da imagem corporal no comportamento alimentar. In Sebastião de Sousa Almeida (et al.) (org.). Psicobiologia do comportamento alimentar. (pp. 103-118). Rio de Janeiro: Rubio.

Baudrillard, Jean. (2011). Tela total: Mito-ironias do virtual e da imagem. Porto Alegre: Sulina. 
Bauman, Zygmunt. (2010). Entrevista - Zygmunt Bauman. Revista Cult. Recuperado em 13 de outubro de 2013, de http://revistacult.uol.com.br/home/2010/03/entrevis-zygmunt-bauman

Bauman, Zygmunt. (2008). Vida para consumo: A transformação das pessoas em mercadoria. Rio de Janeiro: Zahar.

Bauman, Zygmunt. (2005). Identidade. Rio de Janeiro: Jorge Zahar.

Becker, Ernest. (2007). A negação da morte. Rio de Janeiro: Record.

Belting, Hans. (2006). Imagem, mídia e corpo: Uma nova abordagem à iconologia. Revista Ghrebh 8. Disponível em http://revista.cisc.org.br/ghrebh8/artigo.php?dir=artigos\&id=belting_1 Belting, Hans. (2004). Pour Une Anthropologie des Images. Paris: L’Homme.

Benedetti, Cláudia Regina; Romão, Lucília Maria Sousa. (2007). O corpo como discurso: Um contraponto à noção de informação. XXX Encontro Nacional de Estudantes de Biblioteconomia, Documentação, Ciência da Informação e Gestão da Informação: Anais do XXX ENEBD.

Benjamin, Walter. (2000). A obra de arte na época de sua reprodutibilidade técnica. In Adorno (et al). Teoria da Cultura de massa. Trad. de Carlos Nelson Coutinho. (pp. 221-254). São Paulo: Paz e Terra.

Botton, Alain de. (2015). Notícias: Manual do usuário. Rio de Janeiro: Intrínseca.

Brandão, Liv. (2017). Celulite de Anitta gera debate sobre o corpo real. Jornal O Globo. Recuperado em 05 de janeiro de 2018, de https://oglobo.globo.com/cultura/celulite-de-anittagera-debate-sobre-corpo-real-22223368

Brasil, Luciana Leão. (2011). Deslizamento de sentidos por efeito metafórico: O discurso de uma fotografia. RUA [online]. no. 17. Volume 2. Recuperado em 13 de outubro de 2013, de http://www.labeurb.unicamp.br/rua/anteriores/pages/pdf/17-2/4-17-

2.pdfhttp://www.labeurb.unicamp.br/rua/anteriores/pages/pdf/17-2/4-17-2.pdf

Bucci, Eugênio; Kehl, Maria Rita. (2004). Videologias: Ensaios sobre televisão. São Paulo: Boitempo. 
Bystrina, Ivan. (1995). Tópicos de Semiótica da Cultura. São Paulo: Pré-Print Cisc, Tradução: Norval Baitello Júnior e Sônia B. Cartino.

Campelo, Cleide Riva. (1997). Cal(e)idoscorpos: Um estudo semiótico do corpo e seus códigos. São Paulo: Annablume.

Cony, Carlos Heitor. (2004). O tudo e o nada. São Paulo: Publifolha.

CORRA LOLA CORRA. Direção: Tom Tykwer. Intérpretes: Franka Potente; Moritz Bleibtreu; Herbert Knaup e outros. Produção: Stefan Arndt; Gebhard Henke; Andreas Schreitmüller. Título original: Lola Rennt. 81 min. Lançado em 1998.

Courtine, Jean-Jacques. (2008). Introdução. In Alain Corbain; Jean- Jacques Courtine; Georges Vigarello. História do corpo: as mutações do olhar. (pp. 7-12). Petrópolis, RJ: Vozes. v. 3.

Cyrulnik, Boris. (2005). O murmúrio dos fantasmas. São Paulo: Martins Fontes.

Davallon, Jean. (2010). Memória social e produções culturais. In Pierre Achard. O papel da memória. (pp. 23-32). Campinas: Pontes Editores.

Deram, Sophie. (2014). O peso das dietas: Emagreça de forma sustentável dizendo não às dietas! São Paulo: Sensus.

Didi-Huberman, Georges. (2012). Quando as imagens tocam o real. (pp. 204 -219). Belo Horizonte: Pós. v. 2, n. 4, novembro de 2012. Recuperado em 10 de janeiro de 2018, https://www.eba.ufmg.br/revistapos/index.php/pos/article/view/60

DIVERTIDA MENTE. Direção: Pete Docter. Intérpretes: Amy Poehler; Phyllis Smith; Lewis Black e outros. Produção: Jonas Rivera. Título original: Inside Out. 94 min. Lançado em 2015.

Dreifuss, René Armand. (2003). Tecnobergs globais, mundialização e planetarização. In Dênis de Moraes (org.). Por uma outra comunicação: Mídia, mundialização cultural e poder. (pp. 105-137). Rio de Janeiro: Record.

Eco, Umberto (org.). (2010). História da Beleza. Rio de Janeiro: Record. 
Elias, Norbert. (2001). A solidão dos moribundos. Rio de Janeiro: Zahar.

Faria, Daiana Oliveira; Romão, Lucília Maria Sousa. (2012). Google: Considerações sobre o discurso eletrônico. Anais do IX Encontro Virtual de Documentação em Software Livre e VI Congresso Internacional de Linguagem e Tecnologia Online. Recuperado em 10 de maio de 2016, de http://www.periodicos.letras.ufmg.br/index.php/anais_linguagem_tecnologia/article/viewFile/ $1938 / 3469$

Ferrarezi, Ludmila; Romão, Lucília Maria Sousa; Pacífico, Soraya Maria Romano. (2012). Dizeres sobre o feminino em blogs da rede eletrônica. Campinas: Cadernos de Estudos Linguísticos (Unicamp).

FOLHA DE S. PAULO. Manual de Redação. São Paulo, 2007. Publifolha.

Flusser, Vilém. (2002). Filosofia da Caixa Preta: Ensaios para uma futura filosofia da fotografia. Rio de Janeiro: Relume Dumará.

Flusser, Vilém. (1972). A consumidora consumida (isto é: a mulher vista pela sociedade que a faz consumir e que a consome). Comentário - revista trimestral que comenta o mundo e seus problemas. (pp. 35-46). Rio de Janeiro, v. 13, n. 51.

Foxcroft, Louise. (2013). A tirania das dietas: Dois mil anos de luta contra o peso. São Paulo: Três Estrelas.

Gallo, Solange Leda; Romão, Lucília Maria Sousa. (2011). Corpo e(m) discurso na rede. In Lucília Maria Sousa Romão; Fernanda Correa Silveira Galli (orgs.). Rede eletrônica: sentidos e(m) movimento. (pp. 13-22). São Carlos: Pedro \& João Editores.

Garcia, Dantielli Assumpção; Biziak, Jacob dos Santos; Sousa, Lucília Maria Abrahão. (2017). Do cárcere à invenção: Gêneros sexuais na contemporaneidade. São Carlos: Pedro \& João Editores.

Garcia, Dantielli Assumpção; Romão, Lucília Maria Sousa. (2014). Marcha das vadias e a posição-sujeito-mulher: Uma resistência constitutiva. João Pessoa: XVII Congreso Internacional Asociación de Lingüística y Filología de América Latina (Alfal 2014).

Giorgenon, Daniela. (2016). O corpo (inter)face: Sentidos sobre a relação sujeito, corpo e objetos tecnológicos de conexão à rede eletrônica. Tese (doutorado) - Faculdade de Filosofia, Ciências e Letras de Ribeirão Preto da Universidade de São Paulo. Ribeirão Preto. 
Glossário de Termos do Discurso: Projeto de pesquisa A aventura do texto na perspectiva da teoria do discurso: a posição do leitor-autor (2001). Orientadora Maria Cristina Leandro Ferreira. Bolsista de Iniciação Científica Ana Boff de Godoy [et al]. Porto Alegre: UFRGS Instituto de Letras.

Goethe, Johann Wolfgang von. (2004). Fausto: Uma tragédia. São Paulo: Ed. 34.

Goldenberg, Mirian; Ramos, Marcelo Silva. (2002). Em busca dos (H)alteres-ego: Olhares franceses nos bastidores da corpolatria carioca. In Mirian Goldenberg (org.). Nu \& vestido. (pp. 19-40). Rio de Janeiro: Record.

Gorz, André. (2005). O Imaterial: Conhecimento, valor e capital. São Paulo: Annablume.

Gregolin, Maria do Rosário. (2007). Análise do discurso e mídia: A (re)produção de identidades. Revista Comunicação Mídia e Consumo. (pp. 11-25). São Paulo: v. 4, n. 11.

Grünewald, José Lino. (2008). Escreviver. São Paulo: Perspectiva.

Hecht, Jennifer Michael. (2009). O mito da felicidade: Por que o que achamos que é certo é errado. São Paulo: Larousse do Brasil.

Henry, James. (2013). Horas italianas. Belo Horizonte: Autêntica Editora.

Hesse, Hermann. (2009). O lobo da estepe. Rio de Janeiro: Record.

Hesse, Hermann. (2000). Demian. Rio de Janeiro: Record.

Kamper, Dietmar. (2016). Mudança de horizonte: O sol novo a cada dia, nada de novo sob o sol, mas. São Paulo: Paulus.

Kamper. Dietmar. (2002). Imagem. Recuperado em 10 de junho de 2016, de http://www.cisc.org.br/portal/biblioteca/imagemkamper.pdf

Keltner, Dacher; Ekman, Paul. (2015). The Science of "Inside Out". The New York Times. Recuperado em 10 de junho de 2016, de http://www.nytimes.com/2015/07/05/opinion/sunday/the-science-of-inside-out.html?_r=1 
Kotler, Philip; Keller, Kevin Lane. (2012). Administração de Marketing. 14 ed. São Paulo: Pearson Education do Brasil.

Laus, Maria Fernanda (et al.). (2013). A influência da imagem corporal no comportamento alimentar. In Sebastião de Sousa Almeida (et al.) (org.). Psicobiologia do comportamento alimentar. (pp. 103-118). Rio de Janeiro: Rubio.

Le Breton, David. (2003). Adeus ao corpo: Antropologia e sociedade. Campinas: Papirus.

Leal, Tatiane; Filho, João Freire; Rocha, Everardo. (2016). Torches of Freedom: mulheres, cigarros e consumo. (pp. 48-72). Revista Comunicação, Mídia e Consumo. São Paulo, v. 13, n. 38, setembro/dezembro 2016. Recuperado em 10 de janeiro de 2017, de http://revistacmc.espm.br/index.php/revistacmc/article/view/1245/pdf

Malysse, Stéphane. (2002). Em busca dos (H)alteres-ego: Olhares franceses nos bastidores da corpolatria carioca. In Mirian Goldenberg (org.). $\mathrm{Nu} \&$ vestido. (pp. 79-138). Rio de Janeiro: Record.

Maquiavel, Nicolau. (1999). O príncipe: Escritos políticos. São Paulo: Editora Nova Cultural.

Mariani, Bethania. (2009). Sujeitos e discursos contemporâneos. In Freda Indursky; Maria C. L. Ferreira; Solange Mittmann (orgs.). O discurso na contemporaneidade: Materialidades $e$ Fronteiras. São Carlos: Editora Claraluz.

Mariani, Bethania. (2007). Imprensa, produção de sentidos e ética. In Ana Paula Goulart Ribeiro; Lucia Maria Alves Ferreira (orgs.). Mídia e memória. A produção de sentidos nos meios de comunicação. Rio de Janeiro: Mauad.

Mariani, Bethania. (2006). A escrita e os escritos: Reflexões em Análise do Discurso e Psicanálise. São Carlos: Claraluz.

Mariani, Bethania. (1998). O PCB e a imprensa: Os comunistas no imaginário dos jornais (1922-1989). Campinas: Editora da Unicamp.

Medeiros, Caciane Souza de. (2009). A materialidade da imagem e a ideologia no discurso da mídia do espetáculo. (pp. 91-100). Tecnologias de linguagem e produção do conhecimento. Santa Maria: Coleção HiperS @ beres. volume II. dezembro 2009. Recuperado 
em 10 de janeiro de 2017, de

http://w3.ufsm.br/hipersaberes/volumeII/textos_pdf/TXTS_PDF/CACIANE_MEDEIROS.pdf

Medeiros, Caciane Souza de. (2008). As condições de produção e o discurso na mídia: A construção de um percurso de análise. (pp. 48-55). Porto Alegre: Famecos. v. 20, dezembro de 2008.

Milanez, Nilton. (2009). A possessão da subjetividade: Sujeito, corpo e imagem. In João Bôsco Cabral dos Santos (org.). Sujeito e subjetividade: Discursividades contemporâneas. (pp. 281-300). Uberlândia: EDUFU.

Minayo, Maria Cecília de Souza. (2008). O desafio do conhecimento: Pesquisa qualitativa em saúde. São Paulo: Hucitec.

Mittmann, Solange. (2007). Discurso e texto: na pista de uma metodologia de análise. In III Seminário de Estudos em Análise do Discurso, 2007. Anais do II SEAD - seminário de Estudos em Análise do Discurso, Porto Alegre: UFRGS. Recuperado em 10 de julho de 2016, de

http://www.ufrgs.br/analisedodiscurso/anaisdosead/2SEAD/SIMPOSIOS/SolangeMittmann.p df.

Moraes, Dênis de. (2003). O capital da mídia na lógica da globalização. In Dênis de Moraes (org.). Por uma outra comunicação: Mídia, mundialização cultural e poder. (pp. 187-216). Rio de Janeiro: Record.

Morin, Edgar. (2005). Cultura de Massas no Século XX: O Espírito do Tempo - Neurose. São Paulo: Editora Forense Universitária.

Moulian, Tomás. (1999). El consumo me consume. Santiago: LOM Ediciones.

Nunes, José Horta. (2008). O discurso documental na história das ideias: Linguísticas e o caso dos dicionários. (pp. 81-100). São Paulo: Alfa. Recuperado em 15 de janeiro de 2018, de http://seer.fclar.unesp.br/alfa/article/view/1468/1173

Oliveira, João Vitor. (2013). Estresse no trabalho. Revista Espaço Aberto. Recuperado em 05 de janeiro de 2018, de http://www.usp.br/espacoaberto/?materia=estresse-no-trabalho

Orlandi, Eni Puccinelli. (2012a). Discurso em análise: sujeito, sentido, ideologia. Campinas, SP: Pontes Editores. 
Orlandi, Eni Puccinelli. (2012b). Processos de significação, corpo e sujeito. In Aline Fernandes Azevedo (org.). Sujeito, corpo, sentidos. (pp. 13-30). Curitiba: Appris.

Orlandi, Eni Puccinelli. (2011). As formas do silêncio: No movimento dos sentidos. Campinas, SP: Editora da Unicamp.

Orlandi, Eni Puccinelli. (2010). A contrapelo: Incursão teórica na tecnologia - discurso eletrônico, escola, cidade. Campinas: Revista Rua. Recuperado em 10 maio de 2016, de http://www.labeurb.unicamp.br/rua/pages/home/capaArtigo.rua?id=91

Orlandi, Eni Puccinelli. (2009). Análise de Discurso: Princípios e procedimentos. $8^{\mathrm{a}}$ ed. Campinas: Pontes Editores.

Orlandi, Eni Puccinelli. (2005). Discurso e texto: Formulação e circulação dos sentidos. Campinas: Pontes.

Orlandi, Eni Puccinelli. (2003). Para uma enciclopédia da cidade. Campinas: Pontes/Labeurb-Unicamp.

Payer, Maria Onice. (2005). Linguagem e sociedade contemporânea - sujeito, mídia, mercado. Rua - Revista do Núcleo de Desenvolvimento da Criatividade da Unicamp - Nudecri, n. 11, 09-25.

Pêcheux, Michel (2011). Foi "propaganda" mesmo que você disse? In Michel Pêcheux. Análise de Discurso: Michel Pêcheux, textos selecionados por Eni Orlandi. (pp. 73-92). Campinas, SP: Pontes.

Pêcheux, Michel. (2010). O Papel da Memória. In Pierre Achard (et al.). Papel da memória. (pp. 49-57). Campinas, SP: Pontes.

Pêcheux, Michel. (2009). Semântica e Discurso: Uma crítica à afirmação do óbvio. Campinas, SP: Editora da Unicamp.

Peres, Urania Tourinho (2011). Uma ferida a sangrar-lhe a alma. In Sigmund Freud. Luto e melancolia. (pp. 101-137). São Paulo: Cosac Naify.

Pessoa, Fernando. (2006). Quando fui outro. Rio de Janeiro: Objetiva. 
Pondé, Luiz Felipe. (2014). Esperança do mundo. Folha de S. Paulo. Recuperado em 10 de junho de 2016 de http://www1.folha.uol.com.br/colunas/luizfelipeponde/2014/05/1452611esperanca-do-mundo.shtml

Postman, Neil. (1994). Tecnopólio: A rendição da cultura à tecnologia. São Paulo: Nobel.

Priore, Mary Del. (2006). Prefácio para a obra - Do altar às passarelas: Da anorexia santa à anorexia nervosa. São Paulo: Annablume.

Ramonet, Ignacio. (2003). O poder midiático. In Dênis de Moraes (org.). Por uma outra comunicação: Mídia, mundialização cultural e poder. (pp. 243-254). Rio de Janeiro: Record.

REDE DE INTRIGAS. Direção: Sidney Lumet. Intérpretes: Faye Dunaway; William Holden; Peter Finch; Robert Duvall e outros. Produção: Howard Gottfried; Fred C. Caruso. Título original: Network. 121 min. Lançado em 1976.

Resende, Sarah Mota. (2017). Em rede social, miss Canadá rebate críticas ao seu corpo: 'Esta é a geração da diversidade'. Blog Folha. Recuperado em 05 de janeiro de 2018, de http://hashtag.blogfolha.uol.com.br/2017/02/01/esta-e-a-geracao-da-diversidade-em-redesocial-miss-canada-rebate-criticas-ao-seu-corpo/?loggedpaywall

Romão, Lucília Maria Sousa. (2009). A inscrição do político no discurso jornalístico eletrônico. In João Bôsco Cabral dos Santos (org.). Sujeito e subjetividade: Discursividades contemporâneas. (pp. 329-350). Uberlândia: EDUFU.

Romão, Lucília Maria Abrahão e Sousa. (2004). Nós, desconhecidos, na grande rede. Linguagem em (Dis)curso.(pp. 71-91). Tubarão-SC, v. 5.

Ronson, Jon. (2015). Humilhado: Como a era da internet mudou o julgamento público. Rio de Janeiro: Editora Best Seller.

Sahuquillo, María R. (2014). Os médicos franceses expulsam Dukan pelos riscos de sua dieta. Recuperado em 01 de julho de 2016 de https://brasil.elpais.com/brasil/2012/05/08/sociedad/1336497971_046747.html

Sanches, Rodrigo Daniel; Schaufelberger, Maristela. (2016). Cinema: Triste silhueta. Sobre Nossa Visão Distorcida. Recuperado em 01 de julho de 2016 de http://sobrenossavisaodistorcida.com/post/137580246676/cinematristesilhueta 
Sanches, Rodrigo Daniel. (2015). O discurso eletrônico do universo automotivo: Um estudo sobre o novo e a novidade. In Richard Romancini; Maria Immacolata Vassallo de Lopes. Anais do XIV Congresso Ibero-Americano de Comunicação IBERCOM 2015: comunicação, cultura e mídias sociais (org.) - São Paulo: ECA-USP. Recuperado em 10 de junho de 2016, de http://www.assibercom.org/download/Ibercom_2015_Anais_DTI-7.pdf

Sanches, Rodrigo Daniel; Sousa, Lucília Maria Abrahão. (2014). Admirável carro novo: O envelhecimento precoce de discursos e coisas. In Ane Ribeiro Patti (et al.) (org.). Textecendo discursos na contemporaneidade. (pp. 123-136). São Carlos: Pedro \& João Editores.

Sanches, Rodrigo Daniel. (2009). Do homem placa ao pixman: O corpo como suporte midiático. S. J. Rio Preto: FAPESP/Bluecom.

Sanches, Rodrigo Daniel; Baitello Jr., Norval. (no prelo). O processo iconofágico na relação entre o corpo feminino e as imagens midiáticas: O caso Andressa Urach. Revista ECO-Pós: Rio de Janeiro (UFRJ).

Saviano, Roberto. (2014). Zero Zero Zero. São Paulo: Companhia das Letras.

Silverstone, Roger. (2005). Por que estudar a mídia. São Paulo: Edições Loyola.

Sodré, Muniz. (2003). O globalismo como neobarbárie. In Dênis de Moraes (org.). Por uma outra comunicação: Mídia, mundialização cultural e poder. (pp. 21-40). Rio de Janeiro: Record.

Sodré, Muniz. (2002). Antropológica do espelho: Uma teoria da comunicação linear e em rede. Rio de Janeiro: Editora Vozes.

Sousa, Kátia Menezes. (2009). O corpo enunciado e os movimentos de subjetivação e objetivação no reino do virtual. In João Bôsco Cabral dos Santos (org.). Sujeito e subjetividade: discursividades contemporâneas. (pp. 301-328). Uberlândia: EDUFU.

Sousa, Lucília Maria Abrahão; Sanches, Rodrigo Daniel. (2018). O corpo do/no discurso midiático das dietas: Efeitos do novo e da novidade. Revista Famecos (Online). Porto Alegre, v. 25, n. 1, janeiro, fevereiro, março e abril.

Ullmann, Dora; Reis, Telmo Morsch; Steibel, Vera (orgs.). (2004). Princípios básicos da medicina estética. Rio de Janeiro: LetraCapital. 
Vargas, Rejane A.; Medeiros, Caciane Souza de; Beck, Maurício. (2011). Imagens da/na contemporaneidade: Um convite à análise, uma convocação à teoria. RUA [online]. no. 17. Volume 2. Recuperado em 10 de janeiro de 2017, de http://www.labeurb.unicamp.br/rua/anteriores/pages/home/lerArtigo.rua?pdf=1\&id=112

Vinhas, Luciana Lost. (2011). O sujeito, ainda: O ser falante e a análise do discurso. V Seminário de Estudos em Análise do Discurso. Anais do V SEAD - seminário de Estudos em Análise do Discurso. Porto Alegre: UFRGS. Recuperado em 15 de janeiro de 2018, de http://anaisdosead.com.br/5SEAD/SIMPOSIOS/LucianaIostVinhas.pdf

Weinberg, Cybelle; Cordás, Táki Athanássios. (2006). Do altar às passarelas: Da anorexia santa à anorexia nervosa. São Paulo: Annablume. 